\author{
UNIVERSIDADE DE SÃO PAULO \\ ESCOLA DE ARTES, CIÊNCIAS E HUMANIDADES \\ PROGRAMA DE PÓS GRADUAÇÃO EM ESTUDOS CULTURAIS
}

ELIANE MARIA PEREIRA

O ensino das culturas africanas e afro-brasileiras em discurso:

uma análise a partir da Lei 10.639/2003

SÃO PAULO

2018 
ELIANE MARIA PEREIRA

\section{O ensino das culturas africanas e afro-brasileiras em discurso: uma análise a partir da Lei 10.639/2003}

Versão Corrigida

Dissertação apresentada à Escola de Artes, Ciências e Humanidades da Universidade de São Paulo para obtenção do título de Mestre em Filosofia pelo Programa de Pós-Graduação em Estudos Culturais.

Versão corrigida contendo as alterações solicitadas pela comissão julgadora em 15 de outubro de 2018. A versão original encontra-se em acervo reservado na Biblioteca da EACH/USP e na Biblioteca Digital de Teses e Dissertações da USP (BDTB), de acordo com a Resolução CoPGr 6018, de 13 de outubro de 2011.

Área de concentração:

Estudos Culturais

Orientadora:

Prof $^{\mathrm{a}}$. Dra ${ }^{\mathrm{a}}$ : Ana Laura Godinho Lima

\section{SÃO PAULO}


Autorizo a reprodução e divulgação total ou parcial deste trabalho, por qualquer meio convencional ou eletrônico, para fins de estudo e pesquisa, desde que citada a fonte.

Pereira, Eliane Maria

O ensino das culturas africanas e afro-brasileiras em discurso: uma análise a partir da Lei 10.639/2003 / Eliane Maria Pereira ; orientadora, Ana Laura Godinho Lima. - 2018 170 f. : il.

Dissertação (Mestrado em Filosofia) - Programa de PósGraduação em Estudos Culturais, Escola de Artes, Ciências e Humanidades, Universidade de São Paulo, São Paulo.

Versão corrigida

1. Currículo de ensino fundamental - Brasil. 2. Cultura afrobrasileira - Estudo e ensino. 3. Ensino fundamental - Brasil. 4. Formação de professores. 5. Lei 10.639/2003. 6. Análise do discurso. I. Lima, Ana Laura Godinho, orient. II. Título

CDD 22.ed.- 372.190981 
Nome: Pereira, Eliane Maria

Título: O ensino das culturas africanas e afro-brasileiras em discurso:

uma análise a partir da Lei 10.639/2003

Dissertação apresentada à Escola de Arte, Ciências e

Humanidades da Universidade de São Paulo para

obtenção do título de Mestre em Filosofia pelo

Programa de Pós-Graduação em Estudos Culturais.

Área de concentração: Estudos Culturais

Aprovado em 15/10/2018

\section{Banca Examinadora}

Profa. Dra. Luciana Maria Viviani

Julgamento: Aprovada

Profa. Dra. Natália de Lacerda Gil

Julgamento: Aprovada

Profa. Dra. Vivian Batista da Silva

Julgamento: Aprovada
Instituição: $\quad$ EACH - USP

Assinatura:

Instituição: UFRGS

Assinatura:

Instituição: FE - USP

Assinatura: 
Aos meus pais: Maria José e Manoel Mario e, ao meu filho, Arthur. 


\section{AGRADECIMENTOS}

À minha orientadora, Prof ${ }^{a}$. Dr ${ }^{a}$. Ana Laura Godinho Lima, pela oportunidade de sob sua preciosa orientação, desenvolver este trabalho.

À Prof ${ }^{a}$. Dr ${ }^{\text {a }}$. Luciana Maria Viviani e ao Prof. Dr. Marcos Ferreira dos Santos, pela leitura atenta e pelas valiosas contribuições durante o exame de qualificação.

Aos colegas do grupo de estudos foucaultianos, pela oportunidade de construção de novos conhecimentos.

Aos professores do Programa de Mestrado em Estudos Culturais da Escola de Artes Ciências e Humanidades e da Faculdade de Educação da USP com quem tive a oportunidade de vivenciar novas experiências e construir conhecimentos que contribuíram significativamente para o desenvolvimento desse trabalho.

À minha mãe Maria José, que incondicionalmente me incentivou e tanto ajudou durante essa caminhada.

Ao meu filho Arthur, que ainda tão pequeno, compreendia que a mamãe precisava se ausentar para estudar.

Às minhas irmãs Ana, Angela e Maria, assim como ao meu sobrinho Lucas, por toda a ajuda e incentivo.

A todos os amigos e familiares que tanto incentivaram e torceram por mim durante essa jornada. 
"Não importa o que aconteça, continue a nadar". (WALTHERS, 2003). 


\section{RESUMO}

PEREIRA, Eliane Maria. $O$ ensino das culturas africanas e afro-brasileiras em discurso: uma análise a partir da Lei 10.639/2003. 2018. 170 f. Dissertação (Mestrado em Filosofia) Escola de Artes, Ciências e Humanidades, Universidade de São Paulo, São Paulo, 2018. Versão Corrigida.

Esta pesquisa tem como objetivo efetuar uma análise dos discursos produzidos a partir da promulgação da Lei 10.639/2003 que instituiu a obrigatoriedade do ensino das culturas africanas e afro-brasileiras nos currículos de Educação Básica. Inicialmente, foram apresentadas as condições históricas vividas no Brasil associadas à composição multirracial da população brasileira, o persistente racismo que caracteriza a sociedade e as resistências que tomaram forma nos movimentos sociais negros, as quais contribuem para a compreensão dos debates que deram origem ao projeto da lei. Em seguida, além da apresentação da trajetória da legislação no Congresso Nacional e de um exame de seu impacto na produção de livros didáticos e paradidáticos no Brasil, é realizada uma análise detida dos discursos acerca da questão racial contidos nos periódicos educacionais: Nova Escola e Educação, publicados entre os anos de 2003 e 2018 observando os impactos produzidos pela legislação nos discursos veiculados por revistas especializadas na orientação do trabalho docente. A legislação educacional pode promover uma série de modificações discursivas que impactam diretamente a formação docente e o cotidiano escolar. Sendo assim, pode favorecer importantes reflexões e debates, mas também evidenciar as dificuldades encontradas pela comunidade escolar em discutir determinados temas que envolvem problemas sociais, como é o caso do preconceito racial. O tema justifica-se pelo desejo de compreensão de como são dirigidos aos professores os discursos que procuram orientar os processos de transformação de práticas pedagógicas no espaço escolar através da obrigatoriedade legal. A análise evidenciou que os discursos sobre a temática africana e afro-brasileira foram ampliados a partir da promulgação da Lei 10.639/2003 ao longo dos anos, passando a compor o conjunto de conteúdos contemplados em matérias didáticos e periódicos especializados.

Palavras-chave: Culturas Africanas. Lei 10.639/2003. Análise do discurso. Formação de professores. Educação básica. 


\begin{abstract}
PEREIRA, Eliane Maria. The teaching of African and Afro-Brazilian cultures in discourse: an analysis based on Law 10.639 / 2003. 2018. 170 f. Dissertation (Master in Philosophy) - School of Arts, Sciences and Humanities, University of São Paulo, São Paulo, 2018. Corrected Version.

This research aims to analyze the discourses produced after the promulgation of Law 10.639 / 2003 that established the obligation to teach African and Afro-Brazilian cultures in Basic Education curricula. Initially, the historical conditions experienced in Brazil associated with the racial diversity composition of the Brazilian population, the persistent racism that characterizes society and the resistance that took shape in the black social movements were presented, which contribute to the understanding of the debates that gave rise to the project. law. Then, besides the presentation of the trajectory of the legislation in the National Congress and an examination of its impact on the production of didactic and educational materials in Brazil, an analysis is carried out of the discourses about the racial question contained in the educational periodicals: Nova Escola e Educação, carried out between 2003 and 2018, observing the impacts produced by the legislation in the discourses presented in specialized magazines in the orientation of the teaching work. Educational legislation can promote a series of discursive modifications that directly impact teacher education and daily school life. Thus, it may favor important reflections and debates, but also highlight the difficulties encountered by the school community in discussing certain issues that involve social problems, such as racial prejudice. The theme is justified by the desire to understand how the teachers are directed to the discourses that seek to guide the processes of transformation of pedagogical practices in the school space through the legal obligation. The analysis showed that the discourses on the African and Afro-Brazilian themes were amplified as of the enactment of Law 10.639 / 2003 over the years, becoming the set of content covered in didactic and specialized periodicals
\end{abstract}

Keywords: African cultures. Law 10.639 / 2003. Discourse analysis. Teacher training. Basic education. 


\section{SUMÁRIO}

1 INTRODUÇÃO

2 RACISMO À BRASILEIRA: A APROPRIAÇÃO NACIONAL DAS TEORIAS RACIAIS DOS SÉCULOS XVIII E XIX ..................................................................20

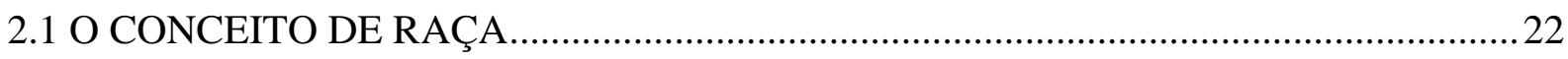

2.2 ALGUNS ASPECTOS DAS INFLUÊNCIAS DOS DISCURSOS CIENTÍFICOS EUROPEUS NO PENSAMENTO CIENTÍFICO BRASILEIRO .........................................2

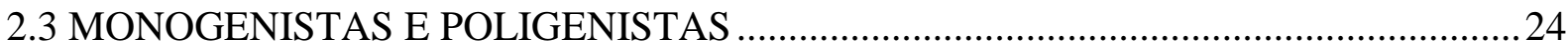

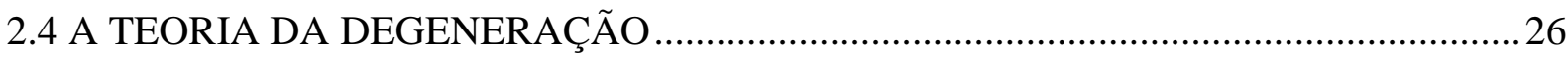

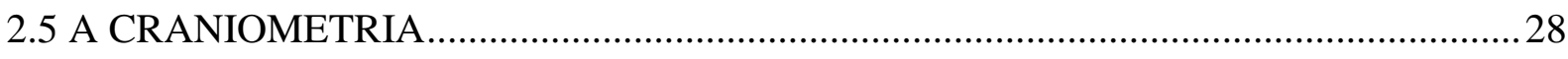

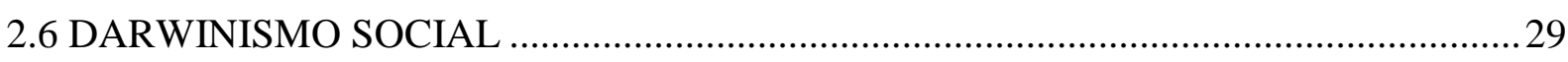

2.7 SOBRE O RACISMO PRESENTE NA PRODUÇÃO DARWINIANA .......................... 30

2.8 UMA BREVE ABORDAGEM SOBRE LAMARK E SUA TEORIA TRANSFORMISTA

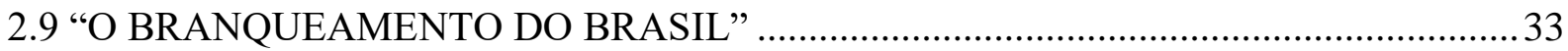

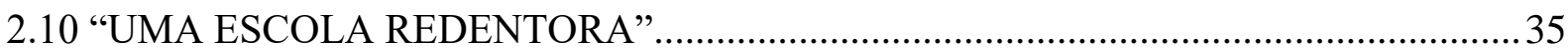

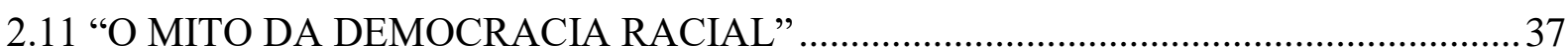

3 OS DISCURSOS DO MOVIMENTO NEGRO ACERCA DA EDUCAÇÃO E DA LEI

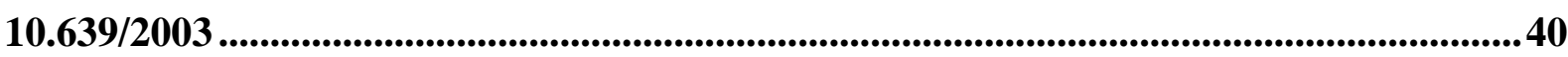

3.1 A LEI 10.639/2003: UMA CONQUISTA HISTÓRICA DO MOVIMENTO NEGRO....42 4 O PROCESSO DE DISCUSSÃO E APROVAÇÃO DA LEI 10.639/2003 E UMA BREVE ANÁLISE DA LEGISLAÇÃ̃ SUBSEQUENTE................................................... 46

4.1 JUSTIFICATIVAS PARA A APRESENTAÇÃO DO PROJETO DE LEI 259 ...............48

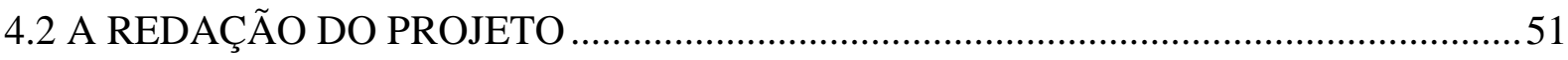

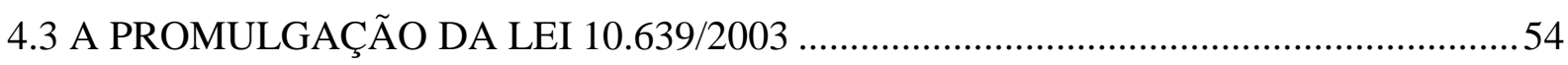

4.4 A LEI 10.639/2003 E AS ALTERAÇÕES CONTIDAS NA LEI 11.645/2008 ................57

4.5 AS DIRETRIZES CURRICULARES NACIONAIS PARA O ENSINO DAS RELAÇÕES ÉTNICO RACIAIS E PARA O ENSINO DE HISTÓRIA E CULTURA AFROBRASILEIRA E AFRICANA

5 A QUESTÃO RACIAL NOS LIVROS DIDÁTICOS E OS IMPACTOS DA LEI 10.639/2003 NA PRODUÇÃO DE LIVROS DIDÁTICOS NO BRASIL .........................63 
5.2 A AVALIAÇÃO DE LIVROS DIDÁticos E A PREOCUPAÇÃO COM A DISCRIMINAÇÃO RACIAL . .65

5.3 A REPRESENTAÇÃO DO NEGRO NOS LIVROS DIDÁtICOS E A REPRESENTAÇÃO DOS MOVIMENTOS SOCIAIS NOS PROGRAMAS DE AVALIAÇÃO DO PNLD . 67

5.4 O IMPACTO DA LEI 10.639/2003 NA PRODUÇÃO DE LIVROS DIDÁTICOS 69

6 UMA ANÁLISE DOS DISCURSOS CONTIDOS NOS PERIÓDICOS EDUCACIONAIS: O ENSINO DAS CULTURAS AFRICANAS E AFROBRASILEIRAS NAS REVISTAS NOVA ESCOLA E EDUCAÇÃO...................................72 6.1 SOBRE OS PROCEDIMENTOS ADOTADOS PARA ANÁLISE DOS ARTIGOS PUBLICADOS PELA REVISTA EDUCAÇÃO E NOVA ESCOLA ……………………......... 72

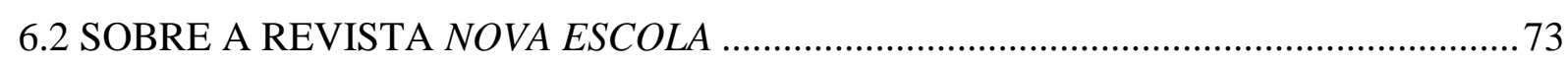

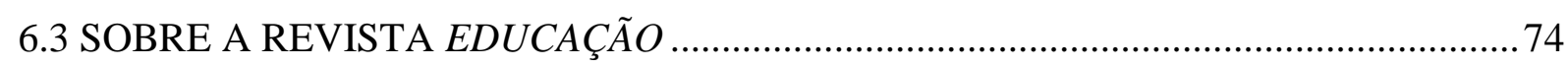

6.4 SOBRE AS CARACTERÍSTICAS DAS PUBLICAÇÕES CATALOGADAS E

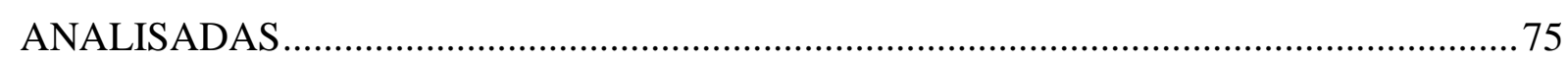

6.5 LEGISLAÇÃO E CONTEXTUALIZAÇÃO SOCIAL ...................................................78

6.6 CONHECIMENTOS GERAIS SOBRE O CONTINENTE AFRICANO..........................79

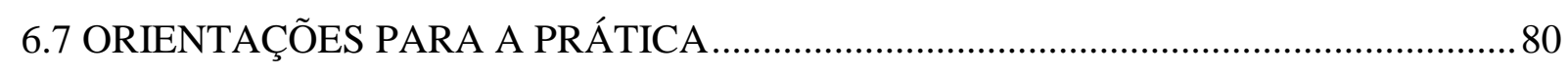

6.8 SOBRE AS IMAGENS QUE ILUSTRAM AS PUBLICAÇÕES ...................................... 82

6. 9 COMO OS DISCURSOS ANALISADOS SE DIRIGEM AOS PROFESSORES?..........83

7 CONCLUSÃO................................................................................................................................86

REFERÊNCIAS .............................................................................................90

ANEXO 1 - SÍNTESE SOBRE LEGISLAÇÕES VOLTADAS ÀS POLÍTICAS DO LIVRO DIDÁTICO NO BRASIL................................................................................104

ANEXO 2 - SÍNTESE DA APRESENTAÇÃO DAS COLEÇÕES DIDÁTICAS DO COMPONENTE CURRICULAR HISTÓRIA NO GUIA DE LIVROS DIDÁTICOS PNLD 2014 106

ANEXO 3 - SÍNTESE dOS TÍTULOS PUBLICADOS PELAS EDITORAS: ÁTICA, MODERNA E SCIPIONE, A PARTIR DO ANO DE 2003, COM TEMÁTICAS RELACIONADAS A CULTURA AFRICANA NO SEGUIMENTO DIDÁTICO, PARADIDÁTICO E DE LITERATURA INFANTIL E LITERATURA INFANTO JUVENIL 
ANEXO 4 - LEVANTAMENTO BIBLIOGRÁFICO - ARTIGOS QUE TRATAM DA LEI 10.639/2003 E SEUS DIRECIONAMENTOS AOS PROFESSORES......................122 ANEXO 5 - LEVANTAMENTO BIBLIOGRÁFICO - DISSERTAÇÕES ....................151 ANEXO 6 - LEVANTAMENTO BIBLIOGRÁFICO - TESES ..........................................158 


\section{INTRODUÇÃO}

A Lei Federal 10.639, promulgada em 09 de janeiro de 1993 pelo então Presidente da República, Luiz Inácio Lula da Silva, tornou obrigatório o ensino das culturas africanas e afro-brasileiras nas escolas de educação básica de todo o país, com o objetivo de reconhecer e promover a valorização das contribuições africanas no processo histórico de construção do Brasil e combater o preconceito racial que se manifesta ainda hoje nas relações sociais no país, inclusive em âmbito escolar ao longo da história através de seus currículos.

Concebida e anunciada como resultado de inúmeras discussões que integraram um processo de luta que envolveu diversos segmentos sociais, especialmente a militância negra, sua homologação vem produzindo ao longo dos anos impactos nos currículos escolares que se desdobraram em debates dentro e fora do espaço escolar, assim como modificações nas produções didáticas e editoriais voltadas para o ensino e para a formação de professores.

A escolha da Lei 10.639/2003 e da produção discursiva dela derivada como tema relevante de investigação científica, decorreu de inquietações surgidas durante a trajetória escolar e profissional desta pesquisadora, que foi diretamente atingida pela homologação da Legislação em questão e a falta de formação para sua aplicação.

As práticas escolares que naturalizam o racismo e o reproduzem, assim como o silêncio de diversos educadores que fizeram parte de minha formação escolar e profissional diante da temática, produziram questionamentos que resultaram no desejo de aprofundar conhecimentos acerca dos discursos originados pela promulgação da Lei 10.639/2003, objetivando tanto legitimá-la quanto preparar o professor para sua implementação no currículo e no cotidiano escolar.

A pesquisa realizada apresenta inicialmente elementos que buscam contribuir para explicar a formação histórica do desprezo e do desrespeito aos negros, bem como a desconsideração das inúmeras contribuições dos diferentes povos africanos para construção social e econômica do Brasil. Em seguida, discorre sobre como os Movimentos de Resistência Negra concebiam a escolarização formal no processo de emancipação social da população negra. Depois disso mostra como se deu o processo de discussão e homologação, assim como a justificativa para a criação da Lei e, finalmente, identifica, apresenta e problematiza os mais recorrentes enunciados contidos nos discursos de publicações pedagógicas destinadas aos professores que legitimam essa Legislação.

A tentativa de romper com as práticas e silêncios reproduzidos pela escola relativos à história e cultura da população negra e de suas inúmeras e fundamentais contribuições para a 
construção cultural, econômica e social do Brasil através de legislação, produziu efeitos que tornam a produção discursiva voltada para o processo de adaptação dos currículos e dos espaços formais de aplicação destes, em campo fértil para a pesquisa científica.

Inicialmente, o trabalho apresentará uma síntese das principais teorias raciais que circularam na Europa e no Brasil entre os séculos XVIII e XIX procurando compreender e explicar as razões para as desigualdades sociais existentes entre brancos e negros a partir de uma perspectiva racial. Essas teorias receberam todo o valor comumente atribuído aos discursos científicos e serviram de embasamento para a construção de novas teorias que buscaram explicar as especificidades da população brasileira e suas possibilidades de desenvolvimento.

Contudo, vale lembrar que tratar a temática africana em qualquer âmbito implica na análise de discursos que expressaram valores aceitos por muito tempo com o status de verdades. Esses discursos circularam socialmente e, no tocante ao racismo, percorreram o mundo.

Os discursos apresentados nesta pesquisa, são principalmente os de gênero científico que procuraram explicar numa perspectiva racial as relações socialmente desiguais vivenciadas entre brancos e negros no contexto Europeu dos séculos XIX e XX, os quais foram amplamente difundidos também no Brasil.

Como principais referenciais teóricos consultados para o desenvolvimento desse levantamento de teorias que compõem a primeira parte deste trabalho de pesquisa, foram escolhidos textos produzidos por Lilian Moritz Schwarcz, Maria Cristina Soares Gouvêa e Carlos Henrique de Sousa Gerken e Stephen Jay Gould, cujos trabalhos contribuíram para a construção de uma revisão histórica das principais teorias raciais e do pensamento científico e social difundidos no Brasil e no mundo, que procuraram justificar o racismo e criar possibilidades para o desenvolvimento e controle social da mestiça população brasileira.

Em O Espetáculo das Raças, de Lilian Moritz Schwarcz, (1993) foi possível encontrar uma descrição detalhada do processo de finalização do escravismo no Brasil e do surgimento de instituições que objetivavam construir e preservar a história do país e de seu povo embasados primordialmente na legitimação da hierarquia social vigente. Para isso, essas instituições assimilaram e se inspiraram em teorias raciais europeias que circularam entre os séculos XVIII e XIX que, numa perspectiva biológica, tentavam explicar as diferenças sociais existentes na sociedade europeia e em suas colônias de exploração ${ }^{1}$. Inspirados nelas, essas

1 Prática de exploração predominantemente empregada pelas nações europeias na qual a metrópole tem como interesse apenas explorar os recursos naturais e a força de trabalho de seus habitantes. Não há preocupação com 
instituições brasileiras produziram e reproduziram outros discursos voltados para explicação do Brasil e de seu futuro social. Observa-se que não existiu absorção total das ideias contidas nas teorias raciais europeias aqui discutidas, sua rejeição, ou seu uso ingênuo por parte dos intelectuais brasileiros, mas sim, a criação de um pensamento original, a partir de um esforço de adaptação à realidade brasileira que possibilitasse a construção de um argumento racial que desse à jovem e mestiça nação a possibilidade de um futuro mais promissor.

Na obra A falsa medida do homem, de Stephen Jay Gould, (2014), o autor analisa dados obtidos a partir de consulta a fontes não oficiais de pesquisa, como anotações e cálculos deixados por cientistas e intelectuais europeus, para refletir e questionar as principais teorias raciais europeias vigentes entre os séculos XVIII e XIX na Europa. A pesquisa desenvolvida permitiu ao autor refazer cálculos e constatar erros em experimentos científicos que deram margem a distorções que resultaram em conclusões equivocadas que, contudo, correspondiam ao esperado pelos cientistas que, com seus experimentos, não encontravam nada além de confirmações para suposições sociais recorrentes em relação às questões raciais e diferenças e problemas sociais como a marginalidade, saúde pública e pobreza.

Os estudos de Gerken e Gouvêa contidos em Desenvolvimento humano: história, conceitos e polêmicas, publicado em 2010, possibilitaram uma melhor compreensão acerca do processo de construção da representação de superioridade do discurso científico na sociedade europeia dos séculos XVIII e XIX e de seu esforço para explicar, numa perspectiva eurocêntrica, os problemas colocados pela sociedade industrial e pela expansão colonialista que proporcionou um contato contínuo entre europeus e os povos considerados primitivos. Os conceitos de raça e evolução foram abordados pelos autores como pontos fundamentais para a construção de conhecimentos sobre o desenvolvimento humano e utilizados para explicar diferenças sociais marcantes entre sociedades distintas. A obra permitiu, portanto, a percepção das relações de poder que atravessam a produção de conhecimentos e da responsabilidade assumida pela ciência em não apenas explicar os fenômenos naturais e sociais, mas também de intervir no real, propondo soluções científicas para os problemas sociais.

Além desses autores, foram de fundamental importância para a compreensão dos sentidos atribuídos à questão racial neste trabalho e as diferenças sociais justificadas pela questão racial, os dados e reflexões contidas em dois clássicos da historiografia brasileira. $O$ povo brasileiro: a formação e o sentido do Brasil, (1995) de Darcy Ribeiro, onde foi tratada a questão da pobreza que separa ricos e pobres agravada pela discriminação que se faz pesar

a terra colonizada, nem tão pouco com sua população originalmente nativa, Objetiva-se apenas sua posse para exploração. 
sobre o índio, o mulato e o negro, além da evidenciação de que a luta mais árdua do negro africano e de seus descendentes brasileiros é, ainda hoje, a conquista de um lugar e de um papel de atuante e participante na sociedade. E a obra de Florestan Fernandes: A integração do negro na sociedade de classes, Volumes I e II (1964; 1965) que, com uma perspectiva social e econômica da inserção social do negro no Brasil após a abolição, elucida as dificuldades encontradas pela população negra para a sua real integração à sociedade, denunciando o descaso e o abandono sofrido por esta população. As discussões realizadas nesta obra corroboram para a justificativa encontrada em muitos discursos que abordam a necessidade de lutas pela criação de políticas públicas que objetivem promover essa já tardia integração social.

Este conjunto de autores compõe o principal referencial teórico que inspirou a construção da primeira parte deste trabalho e que é composto pelos três primeiros capítulos.

A pesquisa também buscou elucidar a importância atribuída pelos discursos do movimento negro à escolarização formal no processo de emancipação social da população negra, abordando a luta pelo direito à escolarização e a promulgação da Lei 10.639/2003, compreendida como conquista histórica e social.

A produção intelectual de Kabenguele Munanga e Nilma Lino dos Santos, dentre outros importantes intelectuais, serviram de aporte teórico para o desenvolvimento deste estudo.

Será também apresentada à trajetória da Legislação que trata do ensino das culturas africanas e afro-brasileiras, desde seu projeto de lei até sua aprovação e promulgação no Congresso Nacional, apresentando seus principais autores e a legislação surgida a partir de sua promulgação através da analise de documentos oficiais disponíveis nas páginas eletrônicas do Congresso Nacional e da Câmara dos Deputados.

O trabalho apresenta ainda uma breve análise dos impactos da legislação na produção de livros didáticos e paradidáticos que compões o PNLD - Programa Nacional do Livro Didático de 2014, onde foi possível observar, tanto nos aspectos quantitativos quanto qualitativos, alguns dos impactos produzidos pela Lei 10.639/2003 na produção de livros didáticos, após dez anos de sua promulgação. Foram reunidos dados referentes a três importantes editoras nacionais que possuem obras constantes no PNLD a mais de uma década e que apresentam de forma clara e concisa em suas páginas eletrônicas informações sobre suas coleções didáticas e livros paradidáticos. Foram elas as editoras Àtica, Moderna e Scipione. 
Por fim, será analisada a produção discursiva direcionada aos professores através das publicações editoriais das revistas Educação e Nova Escola entre os anos de 2003 e 2018 que tiveram como objetivo orientar a atuação docente para o trabalho com as temáticas africana e afro brasileira. O período escolhido compreende a década que se seguiu à promulgação da Lei 10.639/2003 e objetivou-se, ao escolhê-la, demonstrar os impactos quantitativos e qualitativos gerados pela legislação. Nesta etapa será realizado o levantamento e apresentação dos principais enunciados contidos nessas fontes, buscando-se elucidar a forma como esses discursos foram dirigidos aos professores.

Como resultado da investigação foi possível produzir uma narrativa histórica sobre as condições sociais existentes no Brasil associadas à composição multirracial da população brasileira, o persistente racismo que caracteriza a sociedade, as resistências que tomaram forma nos movimentos sociais negros, as quais deram origem ao projeto de Lei 10.639/2003. Já a análise detida dos documentos produzidos no processo de elaboração da lei e seus desdobramentos na imprensa periódica educacional demonstraram um impacto considerável na produção de materiais para a orientação docente, criando alternativas para que a contribuição da cultura africana seja levada em conta no ensino.

Acredita-se que os dados produzidos poderão fomentar discussões acerca dos primeiros efeitos produzidos pela legislação em âmbito escolar, na atuação docente e sobre as relações raciais no espaço escolar, assim como possibilitar a percepção e reflexão sobre novos desafios surgidos a partir da promulgação dessa legislação para educadores e instituições de ensino.

Para situar este trabalho no contexto da produção cientifica demonstrando sua relevância e originalidade fez-se necessária a construção de levantamento da produção científica cuja temática fosse a Lei 10.639/2003. Esse levantamento possibilitou a obtenção de uma amostra significativa dos artigos científicos, dissertações de mestrado e teses de doutorado que tiveram como proposta discutir a legislação e a forma como sua implementação ocorreu nos sistemas escolares brasileiros. Para viabilizar a construção desse mapeamento, fez-se necessário, em razão da extensão territorial do Brasil e da diversidade de envolvidos em produções dos mais variados gêneros, delimitar a produção a ser catalogada. Aplicou-se, então, um recorte temporal e espacial a partir da seleção de artigos, dissertações e teses produzidas no Brasil, entre os anos de 2003 e 2016, constantes no Banco de Dados da Biblioteca Digital Brasileira - BDTB pertencente ao Instituto Brasileiro de Informações em Ciências e Tecnologia. O portal reúne produções em ciência e tecnologia defendidas em todo o país e por brasileiros no exterior. Para realizar a busca, utilizou-se palavras chave com os 
termos: "Lei 10.639/2003", “Análise do discurso" e "Cultura africana”. Os artigos catalogados foram encontrados a partir de buscas com as a mesmas palavras-chave nos portais: Google Acadêmico; Scielo e SIBiUSP (Sistema Integrado de Bibliotecas Universidade de São Paulo) que disponibiliza uma lista de periódicos acadêmicos com mais de dez mil itens.

Os trabalhos consultados, de natureza variada, foram agrupados a partir de seus aspectos metodológicos e epistemológicos permitindo situar a produção surgida a partir da promulgação da Lei 10.639/2003 e o presente trabalho de pesquisa. Foram selecionados para compor o mapeamento construído: 100 artigos científicos, 71 Dissertações de Mestrado e 25 Teses de doutorado.

Como primeira e importante percepção, notou-se um expressivo crescimento de produções científicas que abordam a cultura africana e as implicações da legislação que a torna obrigatória no espaço escolar. Um explícito impacto produzido pela Lei 10.639/2003 que possivelmente resultou em reflexões importantes para a pesquisa educacional brasileira.

Segundo Silva, 2014, no artigo intitulado: "A afro descendência nas investigações científicas: uma década da implementação da Lei 10.639/2003", que objetivou identificar detidamente estudos relacionados a afro descendência entre os anos de 2002 e 2013, foram encontrados poucos, mas crescentes registros de pesquisas acadêmicas que abordassem a temática. Segundo a mesma autora, foram encontradas 17 dissertações diretamente relacionadas a afro descendência e educação entre os anos de 2002 e 2010 no banco de dados da CAPES. Ao realizamos em agosto de 2017 a mesma busca neste banco de dados, encontramos 61 dissertações diretamente relacionadas a essa temática. Utilizando como palavra-chave a expressão “10.639" foram encontradas ainda neste mesmo portal 71 dissertações de mestrados acadêmicos e 11 de mestrados profissionais entre os anos de 2006 e 2016.

Em linhas gerais, o expressivo número de artigos e trabalhos acadêmicos catalogados a partir dos bancos de dados acessados e cuja amostra se faz constar nos anexos deste trabalho de pesquisa, evidenciam o aumento significativo de produções científicas que tratam das temáticas africanas e afro brasileiras a partir da promulgação da Lei 10.639/2003 demonstrando o crescente interesse por estudos relacionados ao ensino das culturas africanas e afro brasileiras justificando a escolha dessa temática como desencadeador de uma pesquisa acadêmica. Dentre os artigos elencados, que demonstram este crescimento destaca-se o trabalho de Raquel Amorim Santos intitulado: Estado do conhecimento da área de educação e Relações raciais em programas de pós-graduação em Educação (2000-2010) que foi 
apresentado no, $25^{\circ}$ simpósio brasileiro de política e administração da educação - ANPAE, realizado em 2011. Esse estudo tem como proposta analisar as teses e dissertações brasileiras relacionadas com a temática Educação e Relações Raciais, defendidas no período de 2000 a 2010 nos Programas de Pós-Graduação em Educação das Instituições Federais e traçar um perfil da produção acadêmica brasileira sobre esta temática. Ele demonstra que as relações raciais nas últimas décadas tem sido objeto de análise de pesquisadores que atuam em diferentes campos do conhecimento, especialmente nas Ciências Sociais. Esses estudos em suas distintas abordagens apontam para "perpetuação" da desigualdade no país. Sua leitura evidencia a necessidade de se promover estudos que possam produzir reflexões acerca do papel atribuído as instituições de ensino no combate ao racismo e a desigualdade social e sobre o impacto da legislação que se propõem a orientar o trabalho das instituições de ensino para a valorização da diversidade cultural e o combate a desigualdades sociais como é o caso da Lei 10.639/2003.

Outro artigo de grande relevância para a construção deste trabalho de pesquisa foi o artigo de Nilma Lino Gomes intitulado: As práticas pedagógicas de trabalho com relações étnico-raciais na escola na perspectiva de Lei 10.639/2003: desafios para a política educacional e indagações para a pesquisa. Nele a pesquisadora tem como proposta mapear e analisar as práticas pedagógicas desenvolvidas pelas escolas públicas e pelas redes de ensino de acordo com a Lei 10.639/2003, a fim de subsidiar e induzir políticas e práticas de implementação desta Lei em nível nacional em consonância com o Plano Nacional de Implementação das Diretrizes Curriculares Nacionais para a Educação das Relações ÉtnicoRaciais e para o Ensino de História e Cultura Afro-Brasileira e Africana. O trabalho da pesquisadora evidenciou uma preocupação que se faz presente em vários artigos catalogados em relação a necessidade de se promover orientação e formação contínua aos professores para concretizar o efetivo trabalho com a temática.

Em linhas gerais observou-se que a produção discursiva elencada demonstra ter como proposta: realizar investigações relacionadas a presença da temática africana em livros e materiais didáticos; Problematizam a gestão escolar para as relações étnico-raciais em comunidades Quilombolas; Apresentam e analisam práticas pedagógicas direcionadas ao ensino das culturas africanas e afro brasileiras; Investigam impactos produzidos pela Legislação 10.639/2003 nos currículos escolares; Analisam iniciativas públicas de formação de professores para o trabalho com as temáticas africanas; Promovem estudos do texto da Lei 10.639/2003 ressaltando sua relevância e destacando as dificuldades para sua implementação; Produzem levantamentos de políticas públicas de ações afirmativas voltadas à educação da 
população negra; Elencam e discutem dificuldades apontadas por professores para o ensino das culturas africanas e afro brasileiras; Acompanham o desenvolvimento, descrevem e discutem projetos desenvolvidos por professores sobre culturas africanas e temas a elas relacionadas; Debatem o preconceito e sua reprodução no espaço escolar e em materiais didáticos; Apresentam e debatem as dificuldades encontradas por estudantes negros durante o processo de escolarização formal; Analisam e debatem textos de literatura africana; Denunciam e debatem a intolerância religiosa no espaço escolar; Analisam e promovem críticas aos processos de implementação da legislação; Denunciam a permanência de currículos etnocêntricos; Denunciam e discutem a baixa oferta de oportunidades de formação direcionadas aos professores antes e depois de sua formação, além de problematizar a qualidade das oportunidades de formação ofertadas.

Não foram encontradas nos bancos de dados pesquisados, dissertações que se propusessem a analisar a produção discursiva dirigida aos professores de educação básica a partir de artigos publicados em periódicos de grande circulação, cuja finalidade seja orientar a atuação docente para o trabalho com a temática africana, assim como proposto neste trabalho de pesquisa. Este trata-se, portanto, de um trabalho inédito que poderá contribuir para a produção de novos conhecimentos e debates em âmbito acadêmico e científico, assim como contribuir para a construção de debates acerca da formação de professores para o ensino das culturas africanas e afro brasileiras. 


\section{RACISMO À BRASILEIRA²: A APROPRIAÇÃO NACIONAL DAS TEORIAS RACIAIS DOS SÉCULOS XVIII E XIX}

Entre os séculos XVIII e XIX prevaleceram as teorias raciais formuladas por importantes intelectuais como Arthur de Gobineau, Louis Agassiz e Samuel George Morton, entre outros, acerca da origem e desenvolvimento humano. De um modo geral, essas teorias buscaram comprovar cientificamente a superioridade hierárquica da raça branca em relação às demais raças. Propagadas pelo mundo a partir da expansão imperialista europeia ${ }^{3}$, essas teorias disseminaram a noção de que existiria uma divisão biológica correspondente à desigualdade social entre os grupos humanos. Essa divisão seccionou a humanidade em brancos, pretos e amarelos (índios e orientais), classificando e posicionando os seres humanos em uma escala que lhes conferia grau superior ou inferior.

Nesse sentido, torna-se importante ressaltar que a utilização da Ciência para comprovar uma concepção social que conferia a determinado grupo uma suposta superioridade esteve estreitamente relacionada à necessidade de legitimar práticas imperialistas de exploração de povos asiáticos, indígenas e negros em várias regiões do Mundo. É por isso que, conforme Schwarcz (1993) torna-se possível afirmar que o argumento racial europeu se tratou de um constructo social, assim como o conceito de raça, cuja aceitação fora incentivada com fins econômicos para sustentar as práticas de exploração e violência a que foram submetidos os povos subjugados pelas nações exploradoras.

O tipo de argumento racial construído no Brasil entre os anos de 1870 e 1930 foi profundamente influenciado pelas teorias racistas europeias, fazendo com que se intensificassem ainda mais as marcas da exploração e escravização dos negros na sociedade. Esse argumento racial não se tratou de uma cópia fiel das teorias europeias, mas sim, do fundamento científico que embasou um esforço gigantesco empregado pelos intelectuais nacionais para compreender as origens da população brasileira e seus problemas sociais.

Pensar a condição social da população negra na sociedade brasileira exige daqueles que desejam debruçar-se sobre essa questão a clareza de que a Lei Áurea ${ }^{4}$, assinada pela

\footnotetext{
2 O conceito foi tratado por Edward Telles na obra intitulada Racismo à Brasileira, publicada em 2003.

${ }^{3}$ A expansão imperialista europeia deu início à chamada fase imperialista do capitalismo, da qual participaria a maioria das nações industrializadas. Uma das formas adotadas pelo imperialismo nessa expansão foi a partilha da África e da Ásia, a criação de áreas de influência em diversas regiões do planeta e a formação de novos impérios coloniais. (PAZZINATO \& SENISE, 2002, p. 226).

4 A Lei Áurea, Lei n 3.353 foi sancionada pela Princesa Isabel no dia 13 de maio de 1888, e concedeu liberdade total aos cerca de 700 mil escravos que ainda existiam no Brasil abolindo a escravidão no país.
} 
Princesa Isabel em 13 de maio de 1888, concedendo à população negra escrava a sonhada liberdade, não trouxe resultados positivos imediatos a essa população, mas sim, junto com o complexo choque entre o sonho de liberdade de muitos e a temida perda de privilégios de poucos, consequências dolorosas para essa já marginalizada população.

A luta dos negros por um espaço social era árdua. Estavam, segundo Fernandes (apud Maringoni, 2011) completamente sozinhos. O Estado, por sua vez, não propôs nenhum plano de assistência que objetivasse a inclusão dos ex-escravos na ascendente sociedade de classes brasileira.

Destaca-se nesse momento histórico e econômico a "competição" extremamente desigual gerada pelo incentivo à entrada maciça de europeus e asiáticos no país que fomentava ainda mais profundamente o preconceito e a inferiorização da população negra na sociedade. A abertura do país à população branca europeia e, posteriormente asiática, esteve diretamente vinculada à necessidade de mão de obra especializada para o trabalho na produção agrícola e industrial, de que se procurou excluir os negros "recém-libertos".

Nem o Estado nem a população estiveram preocupados com inserção social dos exescravos. Ao contrário disso, existia sim um esforço em apagar o mais rápido possível do povo que se desejava formar no Brasil, os traços africanos que, a essa altura, representava um atraso social perpétuo. Esse esforço deixou como herança desigualdades sociais palpáveis entre as populações branca e negra no Brasil, como o fato de negros receberem salários menores, possuírem formação profissional e escolar inferior aos brancos e de uma série de outros exemplos que configuram a situação de exclusão e desigualdade que marca a trajetória da população negra historicamente neste país.

São ainda muito latentes na sociedade brasileira as sequelas de um sistema escravocrata que durou mais de trezentos anos, assim como a falta de ações que viabilizassem a real integração do negro à sociedade em condições de igualdade com a população branca. A desvalorização do negro esteve atrelada ao abandono dessa população como demonstram diversos estudos e pesquisas.

A taxa de analfabetismo é, segundo pesquisa realizada em 2010 pelo Instituto Brasileiro de Geografia e Estatística (IBGE), duas vezes maior entre os negros. Em 2013, a população branca tinha 8,8 anos de estudo em média, já a negra, 7,2 anos. A diferença, no entanto, já foi maior. Em 1997, os brancos chegavam a estudar por 6,7 anos em média e os negros interrompiam os estudos nos 4,5 anos - isso seria o equivalente ao primeiro ciclo do ensino fundamental. (IBGE, 2010; 2013). 
De acordo com a mesma pesquisa, a taxa de analfabetismo entre os negros $(11,5)$ é mais de duas vezes maior que entre os brancos $(5,2)$. No ensino superior, a mesma desigualdade pode ser observada.

Segundo dados do Instituto de Pesquisa Econômica Aplicada (IPEA), publicados em 2017, a população negra é vítima de agressão em maior proporção que a população branca seja homem ou mulher, além de possuir uma média salarial até $40 \%$ menor que a dos brancos. (IPEA, 2017).

Diante de um quadro que evidencia a continuidade da condição de exclusão social, se faz pertinente a apresentação e problematização dos discursos que sustentaram e sustentam ainda hoje as desigualdades sociais que acometem a população negra no Brasil.

\subsection{O CONCEITO DE RAÇA}

O conceito de raça em virtude de sua grande complexidade é ainda hoje tema de debates nos meios científico e acadêmico. Podemos encontrar um número considerável de textos dos mais variados gêneros que buscam discutir e apresentar uma definição atual para o conceito, assim como refutar e questionar a pertinência de sua existência ou seu uso indiscriminado em diferentes contextos.

Os primeiros registros de uso do termo "raça" aparecem em documentos do século XVI que tratavam da formação dos Estados nacionais europeus, onde o termo foi utilizado para enfatizar as diferenças linguísticas e históricas existentes entre os povos que compunham a população europeia naquele período.

Em conformidade com Poliakov (1974), no ano de 1684 o francês François Bernier (1625-1688) observou a existência de quatro ou cinco raças de homens, constituídas pelos europeus, agrupando neste rol, também, os egípcios e os hindus morenos, cuja cor seria apenas acidental causada pelo fato de se exporem demais ao sol; os africanos, cuja negrura é característica essencial; os chineses e os japoneses, com ombros largos, rosto chato, nariz achatado, e com "pequenos olhos de porcos". Já os indígenas, eram considerados por Bernier com alguma proximidade em relação aos europeus. O importante desta classificação é que nela o autor identifica o que parece ser "o primeiro escrito em que o termo 'raça' aparece em seu sentido atual", seria, desta forma uma das primeiras acepções e conceituações de "raça" como a entendemos atualmente.

Portanto, a expressão "raça" não era uma palavra nova nas línguas europeias no século XIX, quando, por exemplo, as ciências naturais, sobretudo a Biologia passou a utilizá-la na 
Zoologia e na Botânica como forma de classificação das espécies animais e vegetais. Conforme Blunt (1982), Carl Von Linné, cientista naturalista sueco, conhecido em português como Lineu (1707-1778), por exemplo, fez uso do termo para classificar plantas e, pela primeira vez, incluiu a espécie humana no reino animal.

A utilização da palavra "raça" para se referir ao gênero humano o subdividiu e classificou hierarquicamente legitimando práticas de inferiorização de determinados grupos humanos a partir de suas características físicas. Segundo Gouvêa e Gerken (2010), na obra Systema Naturae, (1973), Lineu definiu a existência de seis raças humanas ou variedades, como as denominou: americana, europeia, asiática, africana, selvagem e monstruosa. Com exceção dos selvagens e monstruosos (assim chamados os que apresentavam malformações congênitas), as demais quatro raças eram classificadas pela cor da pele e por critérios "psicológicos".

Como é possível observar, os contextos de formulação e usos do termo "raça" são bastante controversos e polêmicos fazendo com que sua utilização seja sempre questionada e passível de críticas, reflexões e debates. Ressaltamos que hoje, o próprio conceito natural ou biológico de "raça" quando referente ao homem moderno, não é mais utilizado pela Ciência, aceita somente enquanto determinação biológica na classificação de outros seres vivos.

\subsection{ALGUNS ASPECTOS DAS INFLUÊNCIAS DOS DISCURSOS CIENTÍFICOS EUROPEUS NO PENSAMENTO CIENTÍFICO BRASILEIRO}

Para Lilian Moritz Schwarcz (1994) as teorias raciais europeias dos séculos XVIII e XIX tiveram um papel importantíssimo na legitimação das hierarquias sociais. Num contexto em que o liberalismo se tornara paradigma político e em que a abolição deixará de ser um pesadelo idealizado pela elite colonial e tornara-se uma realidade histórica, essas teorias passaram a servir como aporte teórico e científico de práticas de exploração. Para a autora, as teorias raciais naturalizaram as hierarquias e serviram para revestir de legitimidade científica a organização extremamente desigual, da sociedade brasileira.

$\mathrm{O}$ argumento racial brasileiro foi embasado em conhecimentos científicos, os quais, apesar de seu compromisso com a objetividade, não se dissociam completamente do contexto cultural de sua época, como já foi evidenciado em muitos estudos sobre a produção científica. Nesse sentido, embasados em Gould (2014), é possível crer que o determinismo biológico defendido e adaptado à realidade brasileira originalmente se tratou de um preconceito racial 
refletido pelos cientistas europeus e intelectuais brasileiros em suas esferas de atuação. Isso porque, para o autor:

Se as influências culturais sobre a ciência pudessem ser detectadas nas minúcias mais insignificantes de uma quantificação supostamente objetiva e quase automática, então ficaria demonstrado que o determinismo biológico é um preconceito social refletido pelos cientistas em sua esfera específica de ação. (GOULD, 2014, p.10)

Como bem evidenciou o autor, as teorias raciais vigentes entre os séculos XVIII e XIX eram carregadas de preconceitos que foram incorporados e postos em ação no campo científicos, desde a formulação das hipóteses e dos métodos de pesquisa até a interpretação de seus resultados.

Serão delineadas, a partir daqui, as principais concepções acerca do desenvolvimento humano e teorias raciais europeias elaboradas entre os séculos XVIII e XIX que embasaram as concepções racistas de importantes teóricos brasileiros, tais como Nina Rodrigues, Sílvio Romero, Euclides da Cunha, Oliveira Viana e de outros importantes nomes da elite intelectual brasileira que fomentaram as características essenciais do que Telles (2003) chamou de "racismo à brasileira" ${ }^{5}$, aquele característico da nação, por vezes negado e encoberto, que passa sutilmente da totalidade da sociedade para as relações pessoais de dominação.

O contexto em que essas teorias são incorporadas, adaptadas e transformadas é profundamente marcado pelo novo regime político em vigor, que inspirava a elite intelectual e, sobretudo, os condutores do novo regime político a elevar a recém República Brasileira, em moldes europeus, a uma grande nação.

\subsection{MONOGENISTAS E POLIGENISTAS}

Um dos primeiros debates travados pelos teóricos racistas europeus se deu em torno da busca da origem da humanidade. Procurando respostas e explicações que pudessem elucidar os homens civilizados a acerca de sua própria origem emergiram dois grupos com concepções divergentes sobre esse tema. De um lado os monogenistas, visão que agregou um grande número de intelectuais europeus e que defendia a concepção de uma humanidade una, a partir de Adão, que teria sido a Gênese de todos os homens e, do outro, os poligenistas que defendiam a concepção de que os homens teriam origens distintas e, portanto, as diferenças

\footnotetext{
${ }^{5} \mathrm{O}$ termo faz referência a um modelo tipicamente brasileiro de discriminação racial. Uma complexa relação que abriga mutuamente a desigualdade social atrelado a um racismo velado. $\mathrm{O}$ tema é abordado em profundidade na obra do professor americano e sociólogo Edward Telles, intitulada "Racismo à brasileira", publicada em 2003.
} 
entre os grupos humanos não estavam relacionadas a sua história, mas sim à sua constituição biológica. Segundo Gouvêa e Gerken (2010), na perspectiva monogenista haveria uma igualdade essencial entre as distintas raças humanas e o grau diferenciado de desenvolvimento existente entre elas podia ser explicado por fatores históricos. Acreditava-se, no entanto, que através da educação e da evangelização, todas as raças poderiam alcançar o mesmo grau civilizatório, mesmo reconhecendo a suposta supremacia branca.

A posição monogenista foi acusada de pouco científica e de ser fundada em argumentos religiosos.

Contrários às concepções monogenistas acerca de uma origem única da humanidade e a qualquer possibilidade de progresso que pudesse igualar as diferentes raças em relação ao seu potencial físico e intelectual, defendiam um argumento que divergia da versão bíblica.

Para David Hume ${ }^{6}$ :

[...] Nunca houve uma nação civilizada cuja tez não fosse branca, como tão pouco houve qualquer indivíduo que se destacasse em qualquer ação ou especulação [...] uma diferença tão uniforme e constante não poderia acontecer em tantos países e épocas se a natureza não houvesse estabelecido uma distinção original entre as raças de homens [...] (HUME apud GOULD, 2014, p. 28).

Desenvolvendo-se principalmente nos Estados Unidos, os argumentos poligenistas ajudavam a sustentar o regime escravocrata do país. Para os teóricos poligenistas as diferenças entre raças refletiam não apenas experiências históricas distintas, mas, principalmente, expressariam níveis diferentes de desenvolvimento moral e intelectual.

Os poligenistas afirmavam que os homens teriam origens distintas, tendo partido de diferentes centros de criação que teriam originado humanidades plurais distintas. (SCHWARCZ, 1996).

Segundo Kenny ${ }^{7}$ (2007, apud GOUVÊA e GERKEN, 2010, p. 41) até a publicação de A origem das espécies a posição poligenista se fez dominante nos meios científicos. Com a publicação da obra de Darwin, seus conceitos foram ressignificados à luz da seleção natural. O homem passou a ser entendido como parte da natureza e sua ascendência remetia não mais as figuras bíblicas de Adão e Eva, mas a dos macacos.

Para Gobineau, um dos principais nomes da poligenia, que defendia convictamente a superioridade dos brancos sobre o resto da sociedade, a humanidade estava dividida

\footnotetext{
${ }^{6}$ HUME, D. Tratado da natureza humana: uma tentativa de introduzir o método experimental de raciocínio nos assuntos morais. São Paulo: Ed. UNESP, 2009.

${ }^{7}$ KENNY, R. From the Curse of Ham to the Curse of Nature: The Influence of Natural Selection on the Debate on Human Unity Before the Publication of the Descent of Man. British Journal for the History of Science , v.40, n.3, p. 367-388, set, 2007.
} 
piramidalmente. Assim, o europeu branco, considerado superior racionalmente, deveria ocupar trabalhos e atribuições "intelectuais", enquanto os amarelos e, sobretudo, os negros eram naturalmente desprovidos de inteligência, fadados, desta forma, ao trabalho braçal incessante.

Um contingente de teóricos racistas europeus era eminentemente contra a mistura de raças, principalmente entre negros e brancos, entendendo que os frutos de relações interraciais somente trariam degeneração.

Em relação a situação do povo brasileiro, Gobineau foi taxativo e chegou a afirmar que a sociedade brasileira se destruiria em 200 anos.

Colocando-se a favor da pureza das raças, Gobineau ${ }^{8}$ (1853), comenta:

Eu penso, portanto que a palavra degenerado, se aplicada a um povo, deve significar, e significa que esse povo não tem mais o valor intrínseco que outrora ele possuía, porque ele não tem mais em suas veias o mesmo sangue, cujos cruzamentos sucessivos têm gradualmente modificado o seu valor, dito de outro modo: que com o mesmo nome ele não tem conservado a mesma raça dos seus fundadores: enfim, que o homem da decadência, este que se denomina o homem degenerado, é um produto diferente, do ponto de vista étnico, do herói das grandes épocas. (GOBINEAU, 1853, apud MARINGONI, 2011).

Ao chegar à capital do Brasil em 1869, Gobineau teve que passar a conviver com os que ele chamou de "degenerados brasileiros". Segundo confissões em cartas à família, os momentos de alívio ao sofrimento que passava por estar no Brasil, eram atenuados quando conversava informalmente com o imperador D. Pedro II. Na sua concepção, o imperador era um ariano puro. Em suas correspondências diplomáticas, ele não poupava palavras preconceituosas para expressar a sua opinião sobre os brasileiros, referindo-se a eles como uma população que se compõe de sangue misturado, mulatos, caboclos de graus diferentes. Expõe que essa miscigenação atingiu os brasileiros de diversas posições sociais: "trata-se de uma população totalmente mulata, viciada no sangue e no espírito e assustadoramente feia", queixou-se o conde que viveu no Brasil por quinze meses. (SCHWARCZ, 1993, p.17).

De fato, Gobineau acreditava no fracasso da nação brasileira, não vislumbrando para ela futuro. A única solução possível para o Brasil, em sua concepção, seria a imigração europeia.

\subsection{A TEORIA DA DEGENERAÇÃO}

\footnotetext{
${ }^{8}$ GOBINEAU, A. Essai sur l'inégalité des races humaines. Paris: Librairei de Fienin-Didot, 1853.
} 
A influência exercida pelas teorias científicas acerca do racismo na sociedade brasileira só pode ser bem compreendida a partir da contextualização cultural de uma sociedade na qual a concepção de inferioridade de negros e índios em relação aos brancos fosse um princípio estabelecido. O Brasil não só assimilou e adaptou as teorias e concepções racistas como serviu de laboratório experimental para a elaboração dessas teorias (SCHWARCZ, 1993). Isso porque a miscigenação, ocorreu amplamente na sociedade brasileira, fato que despertou a atenção de importantes estudiosos do período, dentre eles, o naturalista suíço Jean Louis Rodolphe Agassiz.

Fundador do prestigioso Museu Americano de Zoologia Comparada, Luiz Agassiz fez carreira nos Estados Unidos, na Universidade de Harvard e começou a estudar o Brasil na década de 1820. Notório opositor de Darwin, Agassiz era o principal expoente do pensamento criacionista cristão. Para ele, a humanidade, fruto da criação divina, era formada por diferentes espécies independentes que faziam parte de uma cadeia de seres vivos organizada hierarquicamente em uma ordem complexa crescente, onde os seres supostamente menos evoluídos estariam condenados à inferioridade permanente.

Agassiz rejeitava a concepção evolutiva das espécies e compreendia a miscigenação como um fator de degeneração humana. A visita do estudioso ao Brasil, terra mestiça, tinha como objetivo comprovar através de sua observação depreciativa das características da população escrava e de seus descendentes, os males decorrentes da miscigenação.

Agassiz, adepto da teoria da degeneração das raças defendida pelo naturalista francês Buffon, veio em busca dos "mulatos degenerados" e, convicto de tê-los encontrado, fotografou dezenas de pessoas nuas didaticamente expostas e arranjadas para forjar a veracidade de suas teorias. Nada propôs de novo, apenas utilizou-se de procedimentos pseudocientíficos para tentar consolidar valores e concepções culturais vigentes que procuravam fazer o negro ocupar o último escalão em qualquer hierarquia objetivamente estabelecida. (GOULD 2014. p. 34). A esse respeito Agassiz ${ }^{9}$ foi muito claro sobre as suas convicções que, obviamente, refletiram-se nos resultados de suas pesquisas:

Parece-me uma paródia filantrópica afirmar que todas as raças possuem as mesmas capacidades, gozam dos mesmos poderes e mostram as mesmas disposições naturais, e que, como resultado dessa suposta igualdade, tem direito a ocupar a mesma posição na sociedade humana [...] (AGASSIZ, 1850 apud GOULD, 2014, p. $35)$.

A poligenia cristã defendida por Agassiz deu-lhe notória exposição num período em que a junção de conhecimentos científicos que respeitava, permitia e legitimava a manutenção

\footnotetext{
${ }^{9}$ AGASSIZ, L. The diversity of origin of the human races. Christian Examiner n.49, p.110-145, 1850.
} 
de princípios culturais contemplavam os interesses sociais, políticos, econômicos e religiosos vigentes.

Mas, se o cientificismo cristão de Agassiz agradou a muitos, por outro lado, suas duvidosas e polêmicas metodologias de pesquisa científica lhe renderam inúmeras críticas e um posterior descrédito que o conduziu ao quase total esquecimento. Hoje o naturalista é muito mais conhecido e celebrado por suas importantes contribuições acerca da glaciação do que por seus estudos racistas.

\subsection{A CRANIOMETRIA}

Outros importantes nomes da ciência europeia e americana defenderam as concepções poligenistas, mas não de maneira tão cristã. Samuel George Morton, um outro grande expoente nas pesquisas que procuravam comprovar cientificamente a superioridade da raça branca, impressionou a comunidade científica com a sua coleção de crânios. Entre os anos de 1820 e 1851, sua coleção era composta por mais de mil crânios e o estudioso ficou conhecido como o Gólgota americano.

Seus estudos tinham como objetivo comprovar que uma hierarquia racial podia ser estabelecida através de características físicas do cérebro e estabeleceu, para isso, uma hierarquia entre as raças a partir do tamanho médio de seu cérebro.

Morton publicou importantes obras sobre o tamanho dos crânios humanos, dentre elas: Crânia americana, em 1839 e Crânia aegyptica, em 1844. O grande número de ilustrações era uma das características de suas obras. Todas elas comprovando a legitimidade do racismo e as evidências físicas da inferioridade de índios e negros.

Ignorando o fato de que o tamanho do cérebro está relacionado com o tamanho do corpo a que pertence, Morton comparou o tamanho do cérebro de homens brancos adultos com o de mulheres e crianças de outras raças, por vezes desconsiderando as diferenças proporcionais corporais, sempre concluindo que a capacidade craniana da raça branca era maior e que, portanto, os brancos eram superiores às demais raças. É bastante impressionante o fato de Morton, não procurar esconder os registros onde foi possível constatar arredondamentos de cálculos, em diferentes estudos, que sempre elevavam a média de volume craniano da população caucásica. A esse respeito escreveu Gould, 2014, p. 59:

[...] todos os erros de cálculos e as omissões que detectei favorecem a opinião de Morton. Ele arredondou a média negroide egípcia para 79, em vez de elevá-la para 80. As médias alemã e anglo-saxônica por ele citadas são de 90 , quando seus valores corretos são de 88 e 89. Em sua tabulação final ele excluiu um crânio chinês grande 
e uma amostra parcial esquimó, obtendo assim uma média inferior à caucásica. (GOULD, 2014, p.59).

Torna-se evidente que os estudos nos quais muitos intelectuais e cientistas brasileiros buscaram pautar suas convicções para defender e justificar a inferiorização e a manutenção da exploração dos povos não brancos reproduziam valores culturais presentes no contexto em que estavam inseridos.

\subsection{DARWINISMO SOCIAL}

Antes de discorrer sobre o tema é sempre pertinente enfatizar que o chamado "Darwinismo Social" não foi criado por Charles Darwin, mas tratou-se de uma interpretação de sua teoria. Isso porque, como explanou Gouvea e Gerken (2010), foi Spencer que, em sua leitura e divulgação da teoria darwinista atribuiu à palavra evolução o mesmo sentido da expressão "Descendência modificada", utilizada por Darwin.

Embora Darwin rejeitasse essa apropriação, sua visão ficou à sombra da leitura de Spencer que, enquanto autor amplamente difundido no século XIX fez com que o termo fosse plasmado à ideia de progresso, como se tal perspectiva estivesse realmente presente na obra de Darwin (GOUVÊA e GERKEN, 2010, p.29).

A teoria de Darwin (1809-1882) divulgada em sua obra A origem das Espécies, em 1859, se tornou um novo e importante paradigma que oportunizava as discussões raciais e justificava as desigualdades e os processos de dominação. Foi o fato de o conceito de raça ultrapassar campo científico e adentrar o campo social, político e cultural a justificativa da ampliação da apropriação da obra de Darwin para além da Ciência.

Na obra de Darwin, no entanto, o termo evolução esteve presente uma única vez e este autor o refutava como princípio geral $\left(\mathrm{GOULD}^{10}\right.$, apud GOUVÊA e GERKEN, 2010, p. 29). Darwin evitava o uso do termo porque no século XVIII, este era utilizado no campo biológico na teoria embriológica preformista e, portanto, incompatível com sua visão do desenvolvimento orgânico; e porque rejeitava a associação semântica entre evolução e progresso normalmente utilizada na Biologia. $\mathrm{O}$ fato é que, mesmo contrariando os princípios de Darwin, que como exposto não concordava com a associação entre evolução e progresso e sem jamais ter, em sua obra, feito uso de tal associação, sua teoria foi a partir dela apropriada e difundida por diversos países.

\footnotetext{
${ }^{10}$ GOULD. S, J. Darwin e os grandes enigmas da vida. São Paulo: Martins Fontes, 2006.
} 
O evolucionismo, associado a um conjunto de conhecimentos e valores sociais e culturais já enraizados na sociedade europeia, serviu para respaldar as relações de dominação e exploração estabelecidas pelo imperialismo ao mesmo tempo em que tornou ainda mais efervescentes as discussões sobre o desenvolvimento humano e os diversos estudos acerca da questão.

Com o surgimento do Darwinismo Social, o uso de termos Darwinistas como "competição", "seleção do mais forte", "evolução" e "hereditariedade" passa a aparecer em vários ramos do conhecimento como a Psicologia, a Linguística, a Pedagogia, dentre outros.

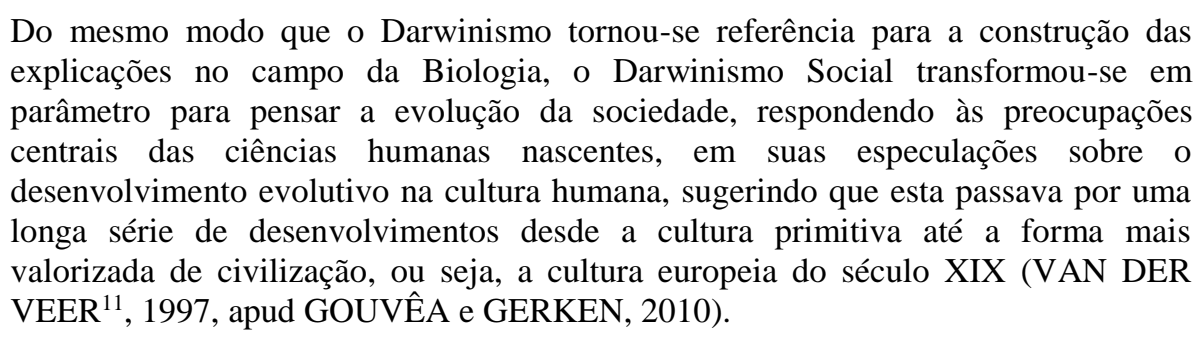

O que observa até aqui é que as teorias racistas do século XIX, receberam o status de verdade cientifica e foram amplamente divulgadas pelo mundo fomentando a construção de explicações científicas para questões sociais que envolviam principalmente as desigualdades entre brancos e negros.

\subsection{SOBRE O RACISMO PRESENTE NA PRODUÇÃO DARWINIANA}

Ainda pouco discutido no meio científico e acadêmico, o pensamento racista presente na obra do naturalista britânico Charles Darwin pode ser mais um exemplo da presença de elementos ideológicos apoiados principalmente em interesses políticos e econômicos europeus que foram reproduzidos através do pensamento científico dos séculos XVIII e XIX.

Segundo Gould, acerca do livro "Origem das Espécies", escrito por Darwin: "Argumentos biológicos em favor do racismo podem ter sido comuns antes de 1859, mas eles aumentaram por ordens de magnitude depois da aceitação da teoria da evolução." (GOULD, 1977, p. 127).

As declarações presentes nos discursos darwinianos relativas a este assunto recebem pouca atenção do meio científico, mas evidenciam claramente a ideia de inferioridade

\footnotetext{
${ }^{11}$ VAN DER VEER, R. The concept of culture in Vigotsky's thinking. Culture \& Psychology, London, n. 3, p. 63-68, v.2, set. 1997.
} 
evolutiva da raça negra aproximando-a dos macacos e a ideia de civilização à raça branca. Essa abordagem pode ser vista na citação a seguir:

Em algum período futuro, não muito distante se medido em séculos, as raças civilizadas do homem vão certamente exterminar e substituir as raças selvagens em todo o mundo. Ao mesmo tempo, os macacos antropomorfos [...] serão sem dúvida exterminados. A distância entre o homem e seus parceiros inferiores será maior, pois mediará entre o homem num estado ainda mais civilizado, esperamos, do que o caucasiano, e algum macaco tão baixo quanto o babuíno, em vez de, como agora, entre o negro ou o australiano e o gorila. (DARWIN ${ }^{12}, 1901$ apud Carvalho, 2009).

Um dos argumentos mais comuns apresentados pelos cientistas darwinianos quando abordados acerca da questão é a alegação de que este importante naturalista britânico era abolicionista. No entanto, este argumento não minimiza a inferiorização da raça negra presente em suas obras, mas demonstra, sim, sua sensibilidade diante da crueldade presente nas práticas escravocratas.

Esta sucinta abordagem da questão de o racismo darwiniano não objetiva esgotar um assunto ainda tão pouco debatido, mas apenas contemplar uma importante questão que também pode evidenciar a presença de elementos culturais nas produções científicas que tentaram explicar as diferenças sociais numa perspectiva racial existentes na Europa e em várias outras partes do Mundo.

\subsection{UMA BREVE ABORDAGEM SOBRE LAMARK E SUA TEORIA TRANSFORMISTA}

Jean Baptiste Pierre Antoine de Monet de Lamarck é considerado um dos fundadores da biologia moderna. Nasceu na França em uma família aristocrata decadente. Exerceu diversas profissões até tornar-se um naturalista profissional por volta do ano de 1790, desenvolvendo importantes estudos relacionados às ciências naturais que resultaram em relevantes trabalhos científicos sobre animais vertebrados e invertebrados, os quais ainda hoje são referência para o estudo dos seres vivos. Lamarck dedicou-se também a trabalhos que buscaram explicar o desenvolvimento humano e seus processos de transformação para adaptação aos ambientes.

No período histórico em que foram desenvolvidas as teorias Lamarckistas, os discursos sobre a criação dos seres vivos e do Fixismo eram pautados em crenças religiosas e conservadoras tanto no meio social quanto no científico. Considerado um importante biólogo

${ }^{12}$ DARWIN, C. The origin of the species. London: John Murray, 1901. 
evolucionista, Lamarck destacou-se ao defender duas hipóteses que tiveram como base empírica a observação e a dedução científica, comumente chamada de teoria do transformismo ou teoria transformista. Nela, Lamarck formulou pressupostos para a evolução biológica, como os de que o ambiente se modificaria de maneira contínua e que os seres vivos adaptar-se-iam ao meio, criando, assim, a ideia de que existiria uma imposição da necessidade evolutiva através do meio biológico.

O cientista formulou a Lei do uso e do desuso, onde defendeu a hipótese de que o esforço contínuo de um ser vivo para sobrevivência em um ambiente poderia fazê-lo desenvolver ou atrofiar partes de seu corpo. Essa concepção reforçava a ideia de que o meio imporia necessidades aos seres vivos de modo que o recorrente esforço empregado provocaria as transformações necessárias à sobrevivência das espécies através de um processo de adaptação.

Outro conceito desenvolvido pelo cientista foi o da Lei das características adquiridas. Essa concepção reforça a ideia de que transformações ocorridas nos organismos em virtude da necessidade de adaptação ao meio seriam transmitidas hereditariamente aos descendentes de uma espécie.

É importante ressaltar que Lamarck não possuía conhecimento em genética, ainda assim, conseguiu deduzir importantes conceitos geneticistas, totalmente desconhecidos em sua época. Foi também o primeiro cientista a utilizar o termo biologia, tendo a coragem de abordar a evolução humana em uma Europa extremamente conservadora e religiosa.

Lamarck não foi o primeiro cientista a admitir mudanças nas espécies. Além dele, Georges Louis Leclerc, o conde de Buffon e Erasmus Darwin, avô do naturalista inglês Charles Darwin já abordavam a questão. No entanto, Lamarck foi o primeiro a desenvolver uma teoria sistematizada sobre a origem e transformação das espécies.

Os estudos de Lamarck acerca da evolução dos seres vivos provocaram importantes debates e inúmeras críticas que por vezes ridicularizaram suas suposições acerca do desenvolvimento dos seres vivos. Ainda que suas hipóteses não tenham sido comprovadas cientificamente, criaram-se a partir de suas ideias, possibilidades de debates que, posteriormente, resultaram no desenvolvimento de diferentes hipóteses científicas acerca da questão. Merece destaque, contudo, a oposição consagrada pelo senso comum entre as teorias evolucionistas ${ }^{13}$ de Jean-Baptiste Lamarck e Charles Darwin, normalmente atribuindo a ideia

\footnotetext{
${ }^{13} \mathrm{O}$ cientista não utilizava em seus estudos o termo evolução, mas sim, progressão. Essa escolha era feita porque no início do século XIX, o termo evolução significava ontogênese, ou seja, o desenvolvimento do ovo à idade adulta.
} 
de erro a teoria lamarckista e consagração a do inglês, Charles Darwin. Essa oposição foi utilizada no fim do século XIX e início de século XX para classificar autores que escreviam acerca da evolução dos seres vivos num período em que o chamado Darwinismo ou teoria da seleção natural ainda não havia se tornado a explicação científica dominante. No entanto, essa oposição teórica é ainda hoje reproduzida em textos de divulgação científica, assim como em materiais didáticos de biologia conforme apontam estudos desenvolvidos a partir da análise de artigos e livros didáticos como a pesquisa realizada por Frezzatti Jr. (2011) intitulado: $A$ construção da oposição entre Lamarck e Darwin e a vinculação de Nietzsche ao Eugenismo.

Essa oposição disseminada do século XIX e início do século XX com o intuito de classificar autores que escreviam sobre o evolucionismo, fossem eles cientistas ou não, ignorou aspectos comuns entre suas teorias, como por exemplo, o fato de alguns aspectos das teorias lamarckistas fazerem-se presentes em A origem das espécies, de 1859. Obra de Charles Darwin, um dos mais inovadores tratados biológicos já escritos, onde foi apresentada a teoria da seleção natural dando início a discussões sobre o tema. Estão presentes nesta obra o uniformismo, o gradualismo, o papel do hábito na fixação de características adquiridas e a questão das lacunas na sequência das espécies.

Sem aprofundar os temas abordados e nem esgotá-los, destaca-se primordialmente a relevância científica dos estudos de Lamarck que, sem dúvida, fomentaram discussões posteriores cujos princípios foram utilizados como pressupostos para a construção de explicações científicas para a ideia de raça e diferenças raciais.

É importante ressaltar que a compreensão que fundamentou a ideia de branqueamento da população brasileira como uma estratégia para o seu desenvolvimento esteve pautada em interpretações das teorias lamarckistas. Dentre elas a de que as deficiências genéticas poderiam ser superadas entre gerações. Nesse sentido, clarear a população através da miscigenação entre brancos e negros configurava-se como uma estratégia para, a partir da suposta superioridade genética branca, superar problemas físicos e sociais existentes na sociedade brasileira.

\section{9 "O BRANQUEAMENTO DO BRASIL”}

Profundamente influenciados pelas teorias racistas europeias e numa tentativa de dar esperança à miscigenada sociedade brasileira, fomentou-se no Brasil a perspectiva de branqueamento da população. Para isso, optou-se pelo incentivo aos casamentos entre mulatos e os brancos além da vinda de imigrantes europeus para o país. Estas foram formas de tentar 
preservar a sociedade que seria consumida pelos mestiços degenerados tão característicos do Brasil, aludindo ao fato de que os resultados dessas ações fariam sobressair a superioridade branca. Segundo Telles (2003), a mistura racial, miscigenação ou mestiçagem constituem a viga em que se apoia a ideologia racial brasileira.

João Baptista Lacerda, conceituado antropólogo e médico, foi um dos principais expoentes da tese do branqueamento. Ao participar, em 1911, do Congresso Universal das Raças, em Paris, defendeu a ideia do fator da miscigenação como algo positivo, no caso brasileiro, por conta da sobreposição dos traços da raça branca sobre as outras, a negra e a indígena. Essa ideia foi defendida através do artigo que em português intitulou-se "Sobre os mestiços do Brasil".

Profundamente influenciado pelas teorias europeias, Lacerda fundamentou-se nas concepções deterministas de Henry Thomas Buckle, no Darwinismo Social de Spencer e nas teorias de Gobineau.

Em sua apresentação, Lacerda fez uso de uma obra do espanhol Modesto Broco que em seu quadro "Redenção de Can" de 1985, representou uma família onde é possível observar à esquerda uma senhora negra olhando para os céus em gesto de agradecimento e uma mulher mestiça segurando uma criança branca, à direita, um homem branco observa a esposa e o filho. A ideia contida no quadro foi defendida por Lacerda. Uma possibilidade de branqueamento através das gerações e, pautado na história bíblica de presente no livro de Gêneses, o fim da maldição de Can que religiosamente era utilizado para justificar a condição de inferior atribuída ao negro.

A ideia defendida por Lacerda estava impregnada pela esperança de livrar a miscigenada população brasileira dos males causados pela mistura de raças. Uma espécie de adaptação das teorias raciais europeias que claramente condenavam as misturas raciais e que, se integralmente aceitas, condenariam o Brasil ao eterno atraso. A teoria defendida por Lacerda, assim como a de diversos intelectuais brasileiros pautavam-se em um contexto marcado pelo fim da escravidão e início de um novo projeto político, onde se procurava construir uma argumentação teórica que pudesse atender ao jogo político em andamento e viabilizar a invenção de uma história política e social para o Brasil que as elites econômicas e intelectuais desejavam ter.

Para Skidmore (1976) os europeus expressavam-se sobre o Brasil de modo pouco lisonjeiro por causa de sua vasta influência africana. Segundo o autor: Ainda segundo o autor, os brasileiros liam as obras europeias sem nenhum espírito crítico e ficavam apreensivos. 
A releitura das teorias racistas dos séculos XVIII e XIX realizadas pelos intelectuais brasileiros, assim como as inúmeras discussões e publicações feitas por estes intelectuais revelam um esforço gigantesco empreendido no sentido de compreender a forma como era constituída a população brasileira e as possibilidades de progresso desse território enquanto nação. Esses intelectuais, assim como as instituições por eles representadas, imbuídos da tarefa de construir "a História Nacional”, procuraram respaldo intelectual na produção científica europeia encontrando no incentivo à imigração europeia para o Brasil, a possibilidade de usufruir dos benefícios do clareamento da população, através da miscigenação.

\subsection{0 "UMA ESCOLA REDENTORA"}

Os discursos acerca das propostas educacionais que vigoraram no Brasil no início da República apresentavam uma preocupação constante e contraditória: o reconhecimento da necessidade de melhor preparar a população para que essa pudesse exercer a cidadania e o temor contínuo de não perder o controle sobre ela em virtude do "poder das letras". Nesse sentido, a escolarização da população configurava-se ao mesmo tempo como uma espécie de antídoto e de veneno social.

O objetivo de promover a escolarização formal da população brasileira esteve presente no projeto de concretização do modelo republicano do país, mas a ideia de instrumentalizar a população para o rompimento com uma ordem social em que as classes dominantes se perpetuassem no comando social e econômico não. Observa-se uma preocupação constante com o que deveria ser ensinado nas escolas numa tentativa de oferecer o benefício do letramento sem permitir a circulação de ideais que pudessem desestabilizar as relações de poder vigentes.

Incumbida de alfabetizar e ensinar os valores essenciais à população, essa escola foi ao longo do período republicano ganhando cada vez mais status de instituição redentora, cuja atuação esteve sempre vigiada. As instituições escolares serviam, também, como importante instrumento de controle político da população à medida que atuava percebendo e afastando o perigo de contaminação desta com ideais revolucionários que ameaçassem o discurso de ordem e progresso no país.

É recorrente nos discursos que orientavam a educação nacional a presença de uma preocupação com o controle sobre a força de trabalho dos recém-libertos, assim como uma percepção preconceituosa a respeito dessa população. 
A escola que instruía e que possibilitava a emancipação da população através da difusão de conhecimentos era também permeada pelos preconceitos de classe e cor vigentes na sociedade brasileira

Nas cidades em geral e no Rio de Janeiro, em particular, há dois elementos presentes: uma classe média inteligente e, em geral, voltada para o bem, e classes inferiores muito miscigenadas, beirando em alguns pontos a classe média, mas quase todas possuindo um fundo hereditário de depravação que transparecerá nas ocasiões de faltas e maus exemplos [...] (PIRES DE ALMEIDA ${ }^{14}, 1882$ apud PATTO, 2017, p. 254).

A ideia de expandir a toda a população o acesso à educação foi bastante debatida e quase sempre rejeitada, tendo em vista os perigos do alfabeto.

A gratuidade do ensino foi motivo de debate porque existia a forte alegação de que a escola se transformaria em um local para a instrução de indigentes, o que aumentaria o perigo da miscigenação entre as pessoas. A esse respeito, Rui Barbosa, Segundo Moraes ${ }^{15}$ (1916) também se pronunciou:

Não venham gabar-nos os benefícios desse regime igualista, que podem assentar ombro a ombro, acotovelando-se, o filho grosseiro de uma família qualquer ao pé de uma jovem educada por uma mãe instruída, casta e de grande coração (MORAES, 1916 apud PATTO, 2007, p. 254).

O discurso de Ruy Barbosa evidencia a existência da defesa de uma escolarização universal, cuja possibilidade de acesso fosse real a todos, no entanto, a crença de que os mais pobres eram propensos a atos criminosos e atitudes que atentavam contra a ordem moral, assim como a certeza da superioridade branca fez com que uma espécie de Aparthaid social ${ }^{16}$ escolar, cujas finalidades educacionais eram distintas e bastante conservadoras, fosse instaurado no início do período republicano perdurando por décadas assim criando, uma escola voltada para a elite e outra para os "de baixo". Para estes a educação adquiria forma de reeducação de jovens criminalizados.

Nota-se que, apesar de bastante presente no discurso político, pouco se fez pela modernização e expansão da educação. O baixo investimento feito pelo Estado, normalmente era superado pelas contribuições feitas pelos empresários, fazendo com que a educação adquirisse características filantrópicas.

\footnotetext{
${ }^{14}$ PIRES DE ALMEIDA, J. R. Histoire de l'Instruction Publique au Brésil (1500-1889). Histoire et Legislation. Rio de Janeiro: Leuzinger, 1889.

${ }^{15}$ MORAES, E. Criminalidade da Infância e da adolescência. Rio de Janeiro: Francisco Alves, 1916.

${ }^{16}$ Segundo Buarque, C. (2003), Apartação ou apartheid social é a diferença que os brasileiros ricos e quase ricos começam a assumir em relação aos pobres; é a aceitação da miséria ao lado, com o cuidado de se construir mecanismos de separação.
} 
As escolas primárias e profissionalizantes normalmente ofereciam ao povo rudimentos de leitura e escrita, habilidades manuais e doutrinação moral e religiosa, tarefa normalmente desempenhada pelas instituições filantrópicas religiosas ou leigas, isso porque pouco se investiu financeiramente.

Não por acaso investia-se pouco em educação, afinal, era preciso ter cautela ao dotar o povo de instrução. A esse respeito, Segundo Patto (2007, p 252), Ruy Barbosa ${ }^{17}$, ressaltou: "Todo cuidado é pouco quando se trata de oferecer aos explorados chaves que possam dar acesso à consciência crítica" [...].

Os valores em que estavam pautados os projetos educacionais na Primeira República ${ }^{18}$ reproduziam a ideia de inferioridade das camadas populares, composta principalmente pelos negros recém-libertos e uma população miscigenada, reforçando um estereótipo que dava a essa população a condição de marginalidade, criminalização e limitação natural.

Essa população só passou a ser público alvo do sistema de ensino de forma mais abrangente e motivo de preocupação que serviu de argumento para legitimar as reformas promovidas na educação pública nos anos de 1920, quando a atuação política da população imigrante branca passou a representar um perigo para a ordem pública.

\subsection{1 "O MITO DA DEMOCRACIA RACIAL"}

Até o ano de 1933, quando ocorre a publicação da obra Casa Grande e Senzala, de Gilberto Freyre, os debates acadêmicos acerca da questão racial no Brasil demonstram-se consensuais acerca do "mal da mestiçagem". Em seu discurso, Freyre sintetizou o processo de formação do povo brasileiro tentando romper com a ideologia discriminatória mostrando as vantagens de ser mestiço. A obra ressalta os aspectos positivos da multirracialidade considerando-a um modelo para a humanidade.

Para fundamentar sua obra, Freyre recorre a um resgate histórico das origens do colonizador português e de seu comportamento sexual em relação à população indígena que aqui encontra. Ressalta as relações sexuais forçadas entre portugueses e nativos e,

\footnotetext{
${ }^{17}$ BARBOSA, R. Reforma do ensino primário. In: Obras Completas de Rui Barbosa, v.10. Rio de Janeiro: Ministério da Educação e Saúde, 1947.

${ }^{18}$ Primeira República Brasileira, ou República Velha refere-se ao período da História do Brasil compreendida entre os anos de 1889, quando ocorreu a Proclamação da República e 1930 quando ocorreu a Revolução Armada que depôs o presidente da república Washington Luís em 24 de outubro e impediu a posse do presidente eleito Júlio Prestes.
} 
posteriormente, com as mulheres negras escravizadas, como indícios de uma inconsistência quanto ao preconceito do colonizador.

$\mathrm{O}$ autor procurou enfraquecer o discurso que propagava a ideia de que o português se sentia racialmente superior em relação à população colonizada ressaltando a ideia de que o próprio português também não teria uma raça pura. Celtas, Fenícios, Gregos, Romanos, Mouros e Judeus, teriam dado origem ao povo português, dando-lhes, assim, uma condição de povo tão miscigenado quanto aquele que viria a compor o povo brasileiro.

Para Freyre, as missões portuguesas e espanholas não eram étnicas, mas cristocêntricas. O que de fato importava era que se pregasse o catolicismo da coroa portuguesa, não a origem dos missionários que por aqui passaram.

O discurso de Gilberto Freyre, que escreveu sua obra quando vivia nos Estados Unidos, onde construiu carreira intelectual, atenuou o recorrente caráter violento impresso nas relações entre brancos e negros no Brasil. Essa visão contrastava com uma realidade que perdura até os dias de hoje, quando ainda são alarmantes os números apresentados por pesquisas que buscam demonstrar a difícil realidade da população negra no país. Nesse sentido, a obra que fundamentou a criação do Mito da Democracia Racial ao mesmo tempo em que contrariava o cientificismo europeu, atenuando a concepção de inferioridade das populações miscigenadas, defendeu a irreal ideia de que brancos e negros vivenciavam harmonicamente suas diferenças sociais.

Para Telles (2003), a obra de Gilberto Freyre ajudou a encobrir externamente o que de fato ocorria e ainda ocorre nas relações sociais brasileiras. A esse respeito é possível citar o estudo encomendado pela Organização das Nações Unidas para a Educação, Ciência e Cultura (UNESCO), em 1955, a Florestan Fernandes e Roger Bastide, com o intuito de confirmar o paradigma construído e difundido pelas elites escravocratas e republicanas de que as relações entre brancos e negros no Brasil eram harmoniosas.

Durante os anos compreendidos entre 1950 e 1952 a UNESCO desenvolveu uma série de pesquisas acerca das relações raciais no Brasil. Isso porque após a segunda Grande Guerra Mundial, essa organização procurou no Brasil uma espécie de modelo que pudesse contrapor aos ideais nazistas.

As pesquisas de Florestan Fernandes e Roger Bastide, diferente do que esperava a UNESCO ao encomendá-las, tomou um rumo inesperado, desmistificando o mito da democracia racial e evidenciando a não integração do negro ex-escravo à ordem competitiva que se formava no país logo após o fim do sistema escravocrata. 
Veementemente contrário ao mito da democracia racial, Florestan Fernandes foi responsável por trabalhos que contribuíram profundamente para uma melhor compreensão sobre a formação e o desenvolvimento do Brasil como Estado-Nação, sempre evidenciando as dificuldades de uma real integração do Negro na sociedade brasileira.

Apesar das inúmeras críticas e debates, além de primorosos trabalhos que buscaram desmistificar a ideia de que o Brasil seria mesmo uma democracia racial, o fato é que são recorrentes as negativas em relação a origem africana entre a população negra, que por vezes, autodeclara-se Morena, como símbolo de orgulho e como busca de aceitação.

É importante ressaltar que Freyre só fez uso da expressão democracia racial tardiamente, já em 1962, mas a essa altura, essa noção aparecia combinada com as mais diversas posições políticas. Tomemos como exemplo o discurso proferido por Abdias do Nascimento, grande líder da luta política da população negra, na abertura do $1^{\circ}$ Congresso do Negro Brasileiro em 1950:

\footnotetext{
Observamos que a larga miscigenação praticada como imperativo de nossa formação histórica, desde o início da colonização do Brasil, está se transformando, por inspiração e imposição das últimas conquistas da Biologia, da Antropologia e da Sociologia, numa bem delineada doutrina da democracia racial, a servir de lição e modelo para outros povos de formação étnica complexa, conforme é o nosso caso. (NASCIMENTO $^{19}, 1968$ apud GUIMARÃES, 2002, p. 67).
}

A ideologia da democracia racial, assim como ocorreu no discurso citado, foi apropriada por diversos segmentos sociais, popularizou-se e difundiu a falsa ideia de que no Brasil o preconceito contra o negro não existe. Era tão forte esse discurso, que acabou sendo reproduzido pelo movimento negro como estratégia de aproximação política de importantes setores da sociedade assumindo a forma de facilitador do diálogo com estes. Em outras palavras, um discurso mais brando como o propagado pelo mito da democracia racial era muito mais aceito do que um discurso de caráter denunciador e combativo.

Florestan Fernandes foi um dos críticos que mais investiu esforços em rebater e denunciar a ideia de que o Brasil fosse uma democracia racial evidenciando que este Mito tornara-se um empecilho para a verdadeira democratização do país. Este mascarava a realidade e impedia que fossem realizadas as mudanças sociais que pudessem de fato transformar o Brasil em uma verdadeira democracia.

\footnotetext{
${ }^{19}$ NASCIMENTO, A. O genocídio do negro brasileiro: processo de um racismo mascarado. Rio de janeiro: Paz e Terra, 1968.
} 


\section{OS DISCURSOS DO MOVIMENTO NEGRO ACERCA DA EDUCAÇÃO E DA LEI $10.639 / 2003$}

Concebida pelo movimento negro como alicerce para a construção da cidadania, via de ascensão social e condição para a desconstrução ideológica do racismo, a educação desde o início esteve na pauta de reivindicações da militância negra.

Ao longo de sua trajetória foram inúmeras as iniciativas realizadas pelo movimento negro com o objetivo de garantir o acesso da população negra à educação. Destaca-se, assim, o papel da Frente Negra Brasileira (FNB), associação de caráter político, informativo, recreativo e beneficente que surgiu em 1931, em São Paulo para tornar-se um movimento articulador nacional. Esta associação promovia a educação a partir da oferta de cursos de alfabetização para crianças, jovens e adultos, visando a integração social do negro, o controle e a denúncia das formas de discriminação racial existentes na sociedade brasileira.

O Teatro Experimental Negro (TEN) ${ }^{20}$, com atuação entre os anos de 1934 e 1968, além de propor-se a contestar a discriminação racial, formar dramaturgos negros e resgatar a herança africana negada pela sociedade brasileira, também promoveu a alfabetização de seus participantes, sobretudo os primeiros, oriundos das camadas menos favorecidas como ocorria com a quase totalidade da população negra. Em seu jornal, "Quilombo", o TEN, entre os anos de 1948 e 1950, reivindicou, através de inúmeras notas, o ensino gratuito para todas as crianças brasileiras e a admissão subvencionada de estudantes negros nas instituições de ensino secundário e superior.

Segundo Nascimento (2004), a requisição de uma abordagem mais positiva da imagem e da História do negro nos currículos das instituições de ensino secundário era um dos pontos mais importantes do programa de educação do Teatro Experimental Negro.

A inclusão da população negra na escola pública, para Dias (2005), foi um dos grandes motivos de mobilização do movimento negro. Entre os anos de 1940 e 1960 é notória a participação desse movimento nos debates educacionais.

Ao analisar a discussão sobre raça no processo de tramitação da Lei de Diretrizes e Bases Educacionais de 1961 (Lei n. 4024), Dias afirma que o termo raça chegou a figurar genericamente no texto legal marcando a importância da atuação do movimento negro nos debates educacionais realizados nesse período. Ainda assim, se faz necessário observar que

\footnotetext{
${ }^{20}$ Projeto idealizado por Abdias Nascimento tinha como proposta a valorização social do negro e da cultura afrobrasileira por meio da educação e arte, além de ambicionar um novo estilo dramatúrgico, com uma estética própria e não apenas a recriação do que se produzia em outros países. (ENCICLOPÉDIA ITAÚ CULTURAL, 2016).
} 
não existiu no corpo textual da legislação nenhuma inferência explícita quanto à plena abertura da educação pública à população negra.

Ainda segundo Dias, a centralidade da questão racial só foi contemplada na Lei de Diretrizes e Bases da Educação de 1996 (Lei 9.394) a partir da alteração dos artigos 26A e 79B pela Lei 10.639/2003.

O Movimento Negro Unificado (MNU) surgido em 1978, em São Paulo, elegeu a educação e o trabalho como duas importantes pautas na luta contra o racismo, sendo este movimento um influenciador na formação de vários intelectuais negros que se tornaram referência acadêmica sobre as relações étnico raciais no Brasil, tais como Abdias do Nascimento, Petronilha Beatriz Gonçalves e Silva, Lélia d'Almeida Gonzales dentre outros.

A abertura política, a partir dos anos de 1980 possibilitou o acesso de alguns ativistas à Universidade, onde puderam aprofundar seus estudos e pesquisas construindo importantes conhecimentos acerca da população negra no mercado de trabalho e, sobretudo, acerca da trajetória dessa população na educação brasileira.

Os anos de 1980 e 1990 marcaram o Movimento Negro pela percepção de que o discurso universalista de acesso à educação não contemplava o atendimento a população negra acentuando a necessidade de se transformar as ações afirmativas como objeto real de luta.

Em 20 de novembro de 1995, foi realizada a Marcha Zumbi dos Palmares contra o Racismo pela Cidadania e a Vida, quando então foi entregue ao Presidente da República Fernando Henrique Cardoso, o Programa de Superação do Racismo e da Desigualdade Étnico Racial, em que a demanda por ações afirmativas se fazia presente como proposta para o ensino superior e o mercado de trabalho. (GOMES, 2012 p. 739). Dentre as propostas apresentada neste Programa estavam:

[...] contra a discriminação racial e a veiculação de ideias racistas nas escolas. Por melhores condições de acesso ao ensino à comunidade negra.

Reformulação dos currículos escolares visando a valorização do papel do negro na História do Brasil e a introdução de materiais como história da África e línguas africanas.

Pela participação dos negros na elaboração dos currículos em todos os níveis e órgãos de ensino. (HASENBALG ${ }^{21}, 1987$ apud SANTOS, S.A. 2005 p.24).

No plano acadêmico, no ano 2000, por iniciativa dos intelectuais Jeruse Romão, Lídia Nunes Cunha e Paulinho de Jesus Francisco Cardoso, foi fundada a Associação Brasileira de Pesquisadores Negros (ABPN), responsável pela organização do Congresso Brasileiro de

\footnotetext{
${ }^{21}$ HASENBALG, C. A. O Negro nas Vésperas do Centenário. Estudos Afro Asiáticos. n.13, p. 79-86, 1987.
} 
Pesquisadores Negros, a COPENE, que em outubro de 2018 realizará sua décima edição. A ABPN congrega pesquisadores que estudam as relações raciais e demais temas de interesse da população negra. Uma associação civil, sem fins lucrativos, filantrópica, assistencial, cultural, científica e independente, que tem por finalidade o ensino, pesquisa e extensão acadêmicocientífica sobre temas de interesse das populações negras do Brasil.

Outro marco importantíssimo na História do Movimento Negro brasileiro foi a sua participação na III Conferência Mundial Contra o Racismo, a Discriminação Racial, a Xenofobia e as Formas Correlatas de Intolerância promovida pela Organização das nações Unidas (ONU) em 2001, em Durban, África do Sul. Enquanto signatário do Plano de Ação de Durban, o Brasil reconheceu internacionalmente a existência institucionalizada do racismo e se comprometeu a construir e aplicar medidas para a sua superação, principalmente voltadas para Educação e Trabalho.

No ano de 2003 foi criada a Secretaria de Políticas de Promoção da Igualdade Racial $(\mathrm{SEPPIR})^{22}$, uma importante mudança no interior da estrutura do Estado, assim como várias universidades públicas passaram a adotar medidas de ações afirmativas como o sistema de Cotas e, em 2004, foi criado junto ao Ministério da Educação a Secretaria de Educação Continuada, Alfabetização e Diversidade (SECAD) ${ }^{23}$, dando ainda mais visibilidade a luta do movimento negro pela Educação.

\subsection{A LEI 10.639/2003: UMA CONQUISTA HISTÓRICA DO MOVIMENTO NEGRO}

Concebida pelos Movimentos Sociais Negros como uma conquista resultante de uma batalha histórica pelo direito à Educação, a promulgação da Lei 10.639/2003 é entendida como parte importante no processo de construção de uma sociedade mais justa e livre de preconceitos e discriminações.

Sancionada em 09 de janeiro de 2003 pelo então Presidente da República Luiz Inácio Lula da Silva, a Lei 10.639 tornou obrigatório o ensino das culturas africanas, da luta dos negros no Brasil, da cultura negra brasileira e do papel do negro na formação da sociedade nacional nos currículos da Educação Básica. Essa determinação legal atendeu a uma parte

22 A Secretaria de Políticas de Promoção da Igualdade Racial foi criada pela Medida Provisória ${ }^{\circ} 111$, de 21 de março de 2003, convertida na Lei no 10.678 de 23 de maio de 2003.

23 Em razão dos decretos n. 7.480 de 2011 e 7.690 de 2012 no que tange à estrutura e função de Secretaria de Educação Continuada, Alfabetização e Diversidade foi acrescentado o eixo "Inclusão" passando a se chamar: Secretaria de Educação Continuada, Alfabetização, Diversidade e Inclusão - (BRASIL, 2012). 
importante das reivindicações do Movimento negro que sempre pautou a garantia de acesso à educação como forma de emancipação social (FERNANDES, 1951).

A preocupação com a Educação formal da população negra se fez presente em diferentes documentos que registraram as pautas de reivindicações do Movimento Negro em seus diferentes momentos históricos e em diferentes regiões do Brasil. A Educação figurava como uma prioridade uma vez que o analfabetismo e a lenta inserção dos negros nas escolas oficiais se constituíam como um dos principais entraves à entrada dessa população no mundo do trabalho.

No jornal Quilombo, dirigido pelo intelectual e militante negro Abdias do Nascimento, a necessidade de educação formal para os negros como condição para a superação da desigualdade racial se fez presente desde a primeira edição, em dezembro de 1948, que, na coluna "Nosso Programa", afirmava a necessidade de

[...] lutar para que, enquanto não for gratuito o ensino em todos os graus, sejam admitidos estudantes negros como pensionistas do Estado em todos os estabelecimentos particulares e oficiais de ensino secundário e superior do país, inclusive nos estabelecimentos militares. (QUILOMBO ${ }^{24}, 2003$ apud Santos, S.A. 2005, p. 22).

As reivindicações presentes no periódico citado e em outras publicações produzidas pelo Movimento Negro chamavam o Estado a sua responsabilidade quanto à necessidade de viabilizar a universalização do ensino público e gratuito responsabilizando-o financeiramente pelos custos referentes a sua negligência.

Segundo Nascimento ${ }^{25}$ (1968 apud SANTOS, S. A. 2005, p.23) Entre os meses de agosto e setembro de 1950, durante a realização do I Congresso Negro Brasileiro que foi promovido pelo Teatro Experimental Negro (TEN), no Rio de Janeiro, se recomendou o estudo da História africana no Brasil, assim como das dificuldades enfrentadas pela população negra na sociedade brasileira e o incentivo a formação de institutos de pesquisa objetivando a construção de conhecimentos formais acerca da história da população negra e de sua condição social a partir de suas reminiscências.

O ressurgimento dos movimentos sociais negros a partir do ano de 1970, foi marcado pela formação de entidades que buscavam denunciar o racismo e organizar a comunidade negra. Dentre eles, destaca-se, por exemplo, o Grupo Palmares, criado em Porto Alegre em 1972; a Sociedade de Intercâmbio Brasil - África (SINBA), inaugurada no Rio de Janeiro em

\footnotetext{
${ }^{24}$ QUILOMBO. Edição fac-similar. Rio de Janeiro: Editora 34, 2003.

${ }^{25}$ NASCIMENTO, A. O genocídio do negro brasileiro: processo de um racismo mascarado. Rio de janeiro: Paz e Terra, 1968.
} 
1974, e o Bloco Afro Ilê Aiyê, fundado em Salvador também em 1974. Motivados por práticas de discriminação racial, como a sofrida por crianças negras que foram impedidas de treinar vôlei no time infantil do clube Regatas Tietê e pelo assassinato do jovem negro Robson Silveira da Luz, no Distrito de Guaianases, para onde havia sido levado preso, acusado de cometer furto em uma feira-livre, militantes de grupos negros, estudantes, atletas, artistas, representantes de organizações culturais e intelectuais, como Clóvis Moura e Florestan Fernandes, organizaram atos públicos como o realizado em 14 de julho de 1978, nas escadarias do Teatro Municipal de São Paulo.

O processo de abertura política que se iniciava no Brasil, a partir de 1985, permitiu a reorganização desses movimentos negros que, além da luta contra o preconceito e a discriminação, trouxeram a Educação como um dos pontos fundamentais presentes na agenda de reivindicações:

Essas reivindicações já se faziam presentes na Convenção Nacional do Negro pela Constituinte, realizada em Brasília - DF, nos dias 26 e 27 de agosto de 1986, quando se reuniram representantes de 63 entidades do Movimento Negro, de 16 Estados brasileiros. Nesse importante evento, as reivindicações formuladas foram:

O processo educacional respeitará todos os aspectos da cultura brasileira. É obrigatória a inclusão nos currículos escolares de I, II e III graus, o ensino de História da África e da História do Negro no Brasil;

Que seja alterada a redação do $\S 8^{\circ}$ do artigo 153 da Constituição Federal, ficando com a seguinte redação: "a publicação dos livros; jornais e periódicos não dependem de licença da autoridade. Fica proibida a propaganda de guerra, subversão da ordem ou de preconceitos de religião, de raça, de cor ou de classe e as publicações e exteriorizações contrárias à moral e aos bons costumes.

(CONVENÇÃO NACIONAL DO NEGRO PELA CONSTITUINTE, p. 4, 1986).

As reivindicações realizadas pelos movimentos sociais acerca da educação iam ano a ano se estruturando e se intensificando. Dentre as propostas apresentada pela Executiva Nacional da Marcha Zumbi dos Palmares estava:

Implementação da Convenção sobre eliminação da Discriminação Racial no Ensino. Monitoramento dos livros didáticos, manuais escolares e programas educativos controlados pela União.

Desenvolvimento de programas permanentes de treinamento de professores e educadores que os habilite a tratar adequadamente com a desigualdade racial, identificar as práticas discriminatórias presentes na escola e o impacto destas na evasão e repetência das crianças negras.

(EXECUTIVA NACIONAL DA MARCHA ZUMBI, p.19, 1996).

É possível observar que o atendimento a algumas reivindicações do Movimento Negro acerca da Educação se deu de forma gradual pelo Estado, como, por exemplo, a revisão de livros didáticos ou mesmo a eliminação de livros em cujo conteúdo, os negros apareciam de 
forma estereotipada, de modo subserviente e negativamente exposto (SANTOS, 2005, p. 25). Essa legislação, enquanto política pública inclusiva teve o importante papel de corrigir a omissão escolar no que tange à cultura afro-brasileira.

A Lei 10.639/2003 aparece nos discursos do Movimento Negro como o resultado de um processo histórico de lutas e reivindicações que se deu desde a abolição da escravatura e se fez presente ao longo da História desse movimento social.

Com a sua aprovação, o Estado brasileiro abandonou o discurso oficial que defendia a existência de uma cultura mestiça, assumindo o compromisso de desenvolver políticas educacionais de reparação e de ações afirmativas em relação às populações negras. Tal ação se configurou como conquista dando legitimidade ao argumento defendido pelo Movimento Negro de que é necessário reparar injustiças contra o negro ao longo da história do Brasil e de que o direito à educação é um dos mais importantes caminhos a se percorrer para desconstruir as bases ideológicas de sustentam o racismo e o preconceito enraizado na sociedade brasileira.

A alteração promovida pela Lei 10.639/2003 na Lei de Diretrizes e Bases da Educação Nacional, Lei 9394/1996 se deu através da adição de dois artigos, foram eles:

Artigo 26 - A: Nos estabelecimentos de ensino fundamental e médio, oficiais e particulares, torna-se obrigatório o ensino sobre a História e Cultura Afro-Brasileira.

Parágrafo Primeiro - O conteúdo programático a que se refere o caput deste artigo incluirá o estudo da África e dos africanos, a luta dos negros no Brasil, a cultura negra brasileira e o negro na formação da sociedade nacional, resgatando a contribuição do povo negro nas áreas social, econômica e política, pertinentes à História do Brasil.

Parágrafo Segundo - Os conteúdos referentes à História e Cultura Afro-Brasileira serão ministrados no âmbito de todo currículo escolar, em especial, nas áreas Educação Artística, de Literatura e História Brasileira.

Artigo 79 - O calendário escolar incluirá o dia 20 de novembro como "Dia Nacional da Consciência Negra” (Brasil, 2003).

Apesar de toda a importância atribuída a essa legislação enquanto conquista histórica e social do Movimento Negro em favor da população brasileira, sobretudo a de origem africana e afro brasileira, muito há ainda a ser realizado para que de fato a implementação dessa legislação efetive-se nos estabelecimentos de ensino. Nesse sentido, seguiu-se a sua publicação um esforço contínuo empregado na construção e publicação de Resoluções e Pareceres que buscaram regulamentar sua implementação nos estabelecimentos de ensino de todo o país. 


\section{O PROCESSO DE DISCUSSÃO E APROVAÇÃO DA LEI 10.639/2003 E UMA BREVE ANÁLISE DA LEGISLAÇÃO SUBSEQUENTE.}

A Lei 10.639/2003 que alterou a Lei de Diretrizes e Bases da Educação Nacional, Lei 9394/1996, tornando obrigatória a inserção das temáticas africanas e afro-brasileiras nos currículos de educação básica de escolas públicas e privadas em todo o Brasil, teve como um de seus principais objetivos possibilitar, através da escolarização formal, a desconstrução de mentalidades e práticas preconceituosas reproduzidas dentro e fora do espaço escolar ao longo da História. Para isso, a legislação objetivou garantir o acesso a conhecimentos que valorizassem a África, os africanos, sua riqueza cultural e contribuições sociais e econômicas que se fizeram profundamente presentes no Brasil em seus mais variados aspectos. A Legislação objetiva proporcionar, por meio de modificações no currículo escolar, condições para a superação das sequelas deixadas pelo longo período de escravização da população negra no país, que resultam, ainda hoje, em práticas racistas manifestas das mais variadas formas nas relações sociais, sobretudo as que se dão através de associações negativas e depreciativas das características físicas dos africanos e seus descendentes, a naturalização da falta de oportunidades de ascensão social e da marginalização dessa população, de sua produção cultural, e de suas contribuições para a construção do país.

Criado a partir de um longo processo de discussões que envolveram os segmentos sociais que lutam por igualdade e justiça, dentre eles o Movimento Negro, vários intelectuais brasileiros dedicados ao estudo das questões raciais no Brasil e representantes políticos eleitos pela sociedade civil, como deputados e senadores que reivindicavam do Estado a inclusão no currículo escolar da História da África, dos africanos, da luta dos negros no Brasil, da cultura negra brasileira e do negro na formação da sociedade brasileira, sua consolidação política se deu na forma do projeto de Lei de número 259, encaminhado em 11 de março de 1999 pelos então Deputados Federais Esther Grossi ${ }^{26}$ e Ben-Hur Ferreira ${ }^{27}$, ambos filiados ao Partido dos trabalhadores - PT. O projeto encaminhado às comissões de Educação, Cultura e Desporto e de Constituição e Justiça e de Redação dispunha, inicialmente, sobre a obrigatoriedade da

\footnotetext{
${ }^{26}$ A educadora Esther Pillar Grossi é reconhecida internacionalmente pelo desenvolvimento de pesquisas e projetos que objetivaram a busca de soluções aos grandes problemas da escola pública brasileira. Foi Deputada Federal pelo PT - Partido dos Trabalhadores no Rio Grande do Sul entre os anos de 1995 e 2002, tendo atuado prioritariamente nas áreas da educação, da cultura e da ciência e tecnologia. (CAMARA DOS DEPUTADOS, 2018).

${ }^{27}$ Eurídio Ben-Hur Ferreira enquanto deputado federal participou das Comissões de Cidadania, Trabalho e de Direitos Humanos (presidente); de Educação (presidente) e de Educação, Cultura, Desporto, Ciência e Tecnologia (membro e presidente). (FUNDAÇÃO GETÚLIO VARGAS, 2009).
} 
inclusão, no currículo oficial da Rede de Ensino, da temática " História e Cultura AfroBrasileira" e outras providências.

Originalmente de autoria do Deputado Humberto $\operatorname{Costa}^{28}$, o projeto expressava parte de reivindicações que já se faziam presentes nos manifestos negros que datam o ano de 1950, como na Declaração Final do I Congresso do Negro Brasileiro, que foi promovido pelo Teatro Experimental do Negro (TEN), no Rio de Janeiro, entre 26 de agosto e 4 de setembro de 1950. Este Congresso do TEN, conforme Maio (2015), representou mais um esforço na construção de uma aliança política antirracista, reunindo militantes e intelectuais negros e brancos, em contexto de denúncias de práticas racistas no Brasil, como foi o caso de grande repercussão à época, da proibição da antropóloga e bailarina negra norte-americana Katherine Dunham de se hospedar no Hotel Esplanada em São Paulo. Esse episódio de racismo foi o motivo para que o escritor e deputado federal Afonso Arinos de Melo Franco ${ }^{29}$ (UDN-DF) apresentasse, em meados do ano de 1950, um projeto de lei que criminaliza atos racistas. Este projeto resultou na Lei 1.390, aprovada em 3 de julho de 1951 pelo Congresso Brasileiro, tornou atos de racismo em contravenção penal. É importante dizer, no entanto, que quando seu autor morreu, em 1990, aos 85 anos, não havia registro de uma única prisão feita com seu embasamento.

Só em 1988 a Lei Afonso Arinos foi substituída por um texto que transformou em crime atos de racismo. Essa modificação ocorreu por autoria deputado negro Carlos Alberto Oliveira $^{30}$, o Caó (PDT-RJ). A Lei 7.716 tornou crime o que era apenas contravenção penal, ampliando as penas para até cinco anos de prisão e manteve os mesmos tipos de crime previstos por Afonso Arinos. Em 1997, o deputado Paulo Paim (PT-RS), também negro, ampliou o alcance da lei antirracismo, incluindo entre as práticas passíveis de punição o xingamento e a ofensa baseados em origem e cor de pele.

É digno de nota que tenham se passado 46 anos para que o Brasil conseguisse construir uma legislação com o intuito de combater e punir atos de racismo e que em seu texto fosse caracterizado de modo mais detalhado e amplo quais seriam essas práticas. A iniciativa

\footnotetext{
${ }^{28}$ O deputado Estadual Humberto Sérgio Costa Lima destacou-se ao presidir as comissões de saúde e direitos humanos, esta última criada por ele. (SENADO FEDERAL, 2018).

${ }^{29}$ Afonso Arinos de Melo Franco foi eleito deputado federal por Minas Gerais entre os anos de 1947 e 1958 foi autor da lei contra a discriminação racial, que tomou o seu nome (Lei n. 1.390, de 3 de julho de 1951). (ACADÊMIA BRASILEIRA DE LETRAS, 2017).

${ }^{30}$ Jornalista e advogado, Caó, quando deputado federal, foi autor da Lei 7.437/85, conhecida como Lei Caó, que mudou o texto da Lei Afonso Arinos, de 1951, e tornou contravenção penal o preconceito de raça, cor, sexo e estado. Também foi responsável pela inclusão na Constituição Federal de 1988 do inciso ao artigo $5^{\circ}$ que tornou racismo crime inafiançável e imprescritível. Depois, ainda foi autor da Lei 7.716/89, que regulamentou o texto constitucional determinando prisão para o crime de preconceito e discriminação racial no país. (NEXO EXPRESSO, 2018)
} 
de combate ao racismo pelo viés educacional teve seus primeiros feitos legais, até a aprovação da lei 10.639/2003, em 1979, quando o Deputado Federal do Estado de São Paulo, pelo Partido Democrático Social (PDS) Adalberto Camargo ${ }^{31}$, propôs um Projeto de Lei, em que pretendia intensificar os conteúdos de afro-brasilidade na disciplina de Estudos Sociais dos currículos de ensino de primeiro e segundo graus. Depois desta, ocorreram outras tentativas de aprovação de leis, propostas por deputados e senadores, como: Abdias do Nascimento ${ }^{32} \mathrm{em}$ 1983; Paulo Paim ${ }^{33}$ em 1988; Benedita da Silva ${ }^{34}$ em 1993 e 1995; Humberto Costa em 1995 e finalmente, Ester Grossi e BenHur Ferreira em 1999. Todos Filiados ao Partido dos trabalhadores - PT.

\subsection{JUSTIFICATIVAS PARA A APRESENTAÇÃO DO PROJETO DE LEI 259}

Como principais justificativas para a apresentação do projeto que objetivou criar condições para a implantação de um currículo na rede oficial de ensino que incluísse o ensino de História da Cultura Afro-brasileira, visando à restauração das contribuições do povo negro no desenvolvimento do país foram destacadas a necessidade de se desmistificar o "eurocentrismo" 35 através da evidenciação e da compreensão dos mecanismos de funcionamento que excluem o que o documento chama de "verdadeira história" do povo negro.

O texto ainda ressalta a necessidade de se alertar os responsáveis pelas produções didáticas acerca dessas distorções e apresenta a concepção de que a educação seria um dos principais instrumentos de garantia do direito à cidadania. Ele chama a atenção do Estado para que este assuma o compromisso político de reconstrução dos currículos escolares a partir da

\footnotetext{
${ }^{31}$ Adalberto Camargo Foi deputado federal por São Paulo. Em seu primeiro ano de mandato, em 1996, apresentou projeto instituindo o Dia da Comunidade Afro-Brasileira. Dentre outras ações criou a Editora AfroBrasileira Ltda., responsável pela publicação da revista Afrochamber, com circulação dirigida a empresários, governos, entidades brasileiras e africanas. (FUNDAÇÃO GETÚLIO VARGAS/CPDOC, 2008).

32 Abdias do Nascimento foi pioneiro do movimento negro no Brasil. Escritor, intelectual, ativista, ator e escultor, Abdias entrou para a política partidária em 1983. Nos anos 40, criou o Teatro Experimental do Negro. Também fundado por ele, o Comitê Democrático Afro-Brasileiro advogou por direitos para as empregadas domésticas e políticas afirmativas para a população negra, propostas levadas à Assembleia Nacional Constituinte de 1946. Apresentou vários projetos com objetivo de combater o racismo e buscar reparação, em razão do escravagismo, à população afrodescendente brasileira. (MUSEU AFRO BRASIL, 2011).

${ }^{33}$ O Deputado Federal Paulo Paim destacou-se pela criação de diversas Leis, entre elas o Estatuto do Idoso (10.741/03) e Estatuto da Igualdade Racial. (PARTIDO DOS TRABALHADORES, 2011).

${ }^{34}$ Benedita da Silva iniciou sua carreira política ao se eleger vereadora do Rio de Janeiro em 1982, após militância na Associação de Favelas do Estado do Rio de Janeiro. (CAMARA DOS DEPUTADOS, 2017).

${ }^{35}$ Este conceito foi amplamente utilizado para se referir aos valores que permeavam a prática exploratória de outros continentes pelos europeus no período das Grandes Navegações e Descobrimentos Marítimos (séculos XV e XVI) e durante o período neocolonial (século XIX) devido ao processo de ocupação e partilha da África e Ásia pelos europeus.
} 
adequação à realidade étnica brasileira, respondendo, assim, aos anseios dos diferentes segmentos da população.

As instituições de ensino e seus currículos são apresentados no documento como um dos principais veículos de sustentação do racismo a partir da ideia de que suas práticas colaboraram para distorção do passado cultural e histórico do povo negro. São pautadas, ainda, as necessidades de reformulação dos currículos escolares no que tangia às deformações que impediam a aproximação da população negra de sua identidade étnica. $O$ documento menciona que a discriminação racial acontece nas escolas públicas quando os agentes pedagógicos não reconhecem o direito à diferença e acabam por negligenciar a particularidade cultural negra. Por fim, o documento apresenta o Brasil como:

[...] fundamentalmente, um país de formação pluriétnica e multicultural. Mas o povo negro ocupa posições subalternas em relação à classe dominante, que considera a cultura afro-brasileira inferior e primitiva, sob a ótica e os parâmetros da cultura branca, que exclui dos currículos escolares e dos livros didáticos a verdadeira contribuição do povo negro na história, desenvolvimento e na cultura do País. (BRASIL, 1999, p. 2-3).

Entregue à Comissão de Educação, Cultura e Desporto em 12 de maio de 1999 e a ele, após cinco sessões, não apresentado nenhuma emenda conforme prazo estabelecido pelo artigo 119, "caput", I e $\S$, do Regimento Interno da Câmara dos Deputados, o projeto de lei 259 foi encaminhado por seus autores, os parlamentares Esther Grossi e Ben-Hur Ferreira, destacando-se os seguintes argumentos:

a) O objetivo principal do projeto que é tornar obrigatório o ensino sobre a História e Cultura Afro-Brasileira nos estabelecimentos de $1^{\circ}$ e $2^{\circ}$ grau, o que hoje recebem o nome de ensino fundamental e médio, compondo a Educação Básica.

b) A discriminação do conteúdo a ser trabalhado nos currículos, como a História da África e dos africanos; a luta dos negros nos Brasil; a cultura negra brasileira; e o negro na formação da sociedade nacional, resgatando a contribuição do povo negro nas áreas: econômica, política e social, pertinentes a História do Brasil.

c) A indicação das áreas de Educação Artística, de Literatura e História como preferenciais para o desenvolvimento do trabalho dos conteúdos referentes à matéria "História e Cultura Afro-Brasileira" e estabelecendo que pelo menos $10 \%$ de seu conteúdo programático anual ou semestral fosse dedicado à temática.

d) A obrigatoriedade de que os cursos de capacitação para professores que regerão as disciplinas especificadas para o desenvolvimento da temática contarão com a participação de entidades do movimento afro-brasileiro, das universidades e instituições de pesquisa pertinentes à temática.

e) A instituição do dia 20 de novembro, como o Dia Nacional da Consciência Negra, sendo esta data inserida no calendário escolar. (BRASIL, 1999, p.1).

O Deputado Evandro Milhomen (PSB), membro da Comissão de Constituição e Justiça de Cidadania no Senado em seu voto julgou o projeto de lei:

[...] louvável e oportuna a iniciativa formulada pelos nobres parlamentares, uma vez que a sociedade há muito sentia a necessidade de ver incluída no currículo da rede 
oficial de ensino uma disciplina que refletisse com maior nitidez a importância do negro africano nas áreas social, cultural, política e econômica, pertinentes à História do Brasil. (BRASÍL, 1999, p.8).

Evandro Milhomen ${ }^{36}$ reconheceu ainda o fato de o Brasil possuir umas das maiores populações negras no mundo e que existem laços fraternos de sangue e cultura que ligam brasileiros e africanos e que, apesar disso, as culturas europeia e Norte Americana continuariam a ser privilegiadas, discriminando-se os valores culturais negros. O Deputado reconhece ainda a falta de uma integração real do negro à sociedade e a necessidade de iniciativas para que a população negra possa verdadeiramente ascender em nossa sociedade e para isso, se faria necessário o resgate da cidadania negra. Sendo assim, conforme o discurso apresentado, o parecer foi no sentido da aprovação do Projeto 259/99, na forma em que foi proposto. A data do voto do relator e do parecer da Comissão de Educação, Cultura e desporto foi 17 de agosto de 1999. Estiveram presentes os Deputados ${ }^{37}$ Maria Elvira - (PMDB), Presidenta; Maria Serrano - (PSDB) e Celcita Pinheiro - (DEM), Vice-Presidentas; Ademir Lucas - (PSDB), Agnelo Queiroz - (PT), Átila Lira - (PSB), Éber Silva - (PDT), Eduardo Seabra - (PTB), Evandro Milhomen (PC do B), Fernando Marroni (PT), Flávio Arns (PSDB), Gastão Vieira - (PMDB), João Matos - (PMDB), Jonival Lucas Júnior - (PPB), José Melo - (PFL), Luis Barbosa - (PSDB), Nelson Merchezan - (PSDB), Nilson Pinto - (PSDB), Norberto Teixeira - (PMDB), Osvaldo Biolchi- (PTB), Oliveira Filho - (PRB) e Pedro Wilson - (PT).

O Projeto de Lei 259 -A, após publicação do parecer favorável e unânime da Comissão de Educação, Cultura e Desporto foi encaminhado à Comissão de Constituição e Justiça e de Redação, por meio do ofício n. p- 347/99 onde após prazo para o recebimento de emendas, seguiu para análise e voto do Deputado Federal André Benasse - (PSDB), onde foram observados, em 26 de maio de 2000, os preceitos constitucionais, jurídicos e de boa técnica, considerando obedecidos os preceitos constitucionais pertinentes.

Em sua versão para apresentação, de 26 de maio de 2000, na argumentação inicial presente na primeira parte de justificação, um de seus autores, o Deputado Ben-Hur Ferreira, apresenta a seguinte ideia:

É urgente e necessário desmistificar o eurocentrismo neste momento em que se quer repensar um novo modelo de sociedade em que todos não somos apenas brancos,

\footnotetext{
${ }^{36}$ Evandro Milhomen Foi vereador em Macapá entre 1997 e 1999, eleito pelo PSB mesmo partido pelo qual se elegeu deputado federal em 1999 e se reelegeu em 2003 para a eleição de 2007 trocou de partido, ingressando no PC do B. Também exerceu o cargo de diretor municipal de Ação Comunitária de Macapá entre 1990 e 1994. (CAMARA DOS DEPUTADOS, 2017).

${ }^{37}$ Os Partidos de filiação indicados no texto correspondem aos do período/ano de assinatura de aprovação do Projeto de Lei, 1999.
} 
como quer fazer crer o livro didático imposto aos estudantes nas escolas. Podemos captar, compreender os mecanismos de funcionamento que excluem a verdadeira história do povo negro, discriminado e excluído nas escolas e nos livros, alertando os responsáveis pela produção de livros didáticos, bem como professores e alunos vítimas destas distorções e omissões nas instituições de ensino. (BRASIL, 1999, p. 259)

Este discurso se fará presente na legislação construída a partir deste projeto de lei repetindo-se nos materiais produzidos para que seu objeto de fato fosse consolidado nos currículos escolares.

\subsection{A REDAÇÃO DO PROJETO}

O texto que seguiu para apreciação do Senado Federal, em 05 de abril de 2002, apresentou a seguinte redação:

Quadro 1 - Projeto de Lei 259/1999

Dispõe sobre a obrigatoriedade da inclusão, no currículo oficial da Rede de Ensino, da temática " História e Cultura Afro-Brasileira" e dá outras providências

O CONGRESSO NACIONAL decreta:

Art $101^{\circ}$ Nos estabelecimentos de ensino fundamental e médio, oficiais e particulares, tornase obrigatório o ensino sobre História e Cultura Afro-Brasileira.

$\S 1^{\circ} \mathrm{O}$ conteúdo programático a que se refere o caput deste artigo incluirá o estudo da História da África e dos africanos, a luta dos negros no Brasil, a cultura negra brasileira e o negro na formação da sociedade nacional, resgatando a contribuição do povo negro nas áreas social, econômica e política pertinentes à História do Brasil.

$\S 2^{\circ}$ Os conteúdos referentes à História e Cultura Afro-Brasileira serão ministrados no âmbito de todo o currículo escolar, em especial nas áreas de Educação Artística e de Literatura e História Brasileiras.

$\S 3^{\circ}$ As disciplinas História do Brasil e Educação Artística, no ensino médio, deverão dedicar, pelo menos, dez por cento de seu conteúdo programático anual ou semestral à temática referida nesta Lei.

Art. $2^{\circ}$ Os cursos de capacitação para professores deverão contar com a participação de entidades do movimento afro-brasileiro, das universidades e de outras instituições de pesquisa pertinentes à matéria.

Art. $3^{\circ} \mathrm{O}$ calendário escolar incluirá o dia 20 de novembro como "Dia Nacional da Consciência Negra".

Art. $4^{\circ}$ Esta Lei entra em vigor na data da sua publicação. 
Brasília, 05 de abril de 2002.

Fonte: Dados extraídos de BRASIL (1999, p. 36)

A aprovação do texto pelo Senado Federal ocorreu em 18 de dezembro de 2002 e ele foi então encaminhado para a Presidência da República, por meio do ofício 1462/2002, que após sua sanção promoveria a alteração da Lei de Diretrizes e Bases da Educação Nacional, Lei 9394/96, com o intuito de incluir no currículo oficial da Rede de Ensino a obrigatoriedade da temática História e Cultura Afro-Brasileira.

A sanção do Presidente da República, Luiz Inácio Lula da Silva ocorreu em 9 de janeiro de 2003 aprovando o Projeto de Lei 259/1999 Publicado no Diário Oficial da União, em 10 de janeiro de 2003, na primeira página da seção 1, como Lei 10.639/2003:

Quadro 2 - Lei 10.639/2003

\section{LEI No 10.639. DE JANEIRO DE 2003}

Altera a Lei $\mathrm{n}^{\circ}$ 9.394, de 20 de dezembro de 1996. que estabelece as diretrizes e bases da educação nacional. para incluir no currículo oficial da Rede de Ensino a obrigatoriedade da temática "História e Cultura Afro-Brasileira", e dá outras providências.

\section{O PRESIDENTE DA REPÚBLICA}

Faço saber que o Congresso Nacional decreta e eu sanciono a seguinte Lei:

Art. $1^{\circ}$ A Lei $\mathrm{n}^{\circ}$ 9.394, de 20 de dezembro de 1996. passa a vigorar acrescida dos seguintes arts. 26-A. 79-A e 79-B:

"Art. 26-A. Nos estabelecimentos de ensino fundamental e médio, oficiais e particulares torna-se obrigatório o ensino sobre História e Cultura Afro-Brasileira.

$\S 1^{\circ} \mathrm{O}$ conteúdo programático a que se refere o Caput deste artigo incluirá o estudo da História da África e a dos Africanos. a luta dos negros no Brasil. a cultura negra brasileira e o negro na formação da sociedade nacional. resgatando a contribuição do povo negro nas áreas social, econômica e política pertinentes à História do Brasil.

$\S 2^{\circ}$ Os conteúdos referentes à História e Cultura Afro-Brasileira serão ministrados no âmbito de todo o currículo escolar. em especial nas áreas de Educação Artística e de Literatura e História Brasileiras.

$\S 3^{\circ}(\mathrm{VETADO}) "$

"Art. 79-A. (VETADO)" AI1. 
79-13. O calendário escolar incluirá o dia 20 de novembro como 'Dia Nacional da Consciência Negra'."

Art. $2^{\circ}$ Esta Lei entra em vigor na data de sua publicação. Brasília, 9 de janeiro de 2003: $182^{\circ}$ da Independência e $115^{\circ}$ da República.

LUIZ INÁCIO LULA DA SILVA Cristovam Ricardo Cavalcanti Buarque

Fonte: (BRASIL, 2003)

Os vetos referentes aos $\S 3^{\circ}$ e "Art. 79-A, que constam no texto sancionado pelo Presidente da República ocorreram com justificativa embasada no $\S 1^{\circ}$ do artigo 66 da Constituição Federal pelas seguintes razões:

Artigo $26 \mathrm{~A}, \S 3^{\circ}$ - O artigo estabelecia que as que as disciplinas de História do Brasil e Educação artística deveriam dedicar pelo menos dez por cento de seu conteúdo programático anual ou semestral à temática africana. A especificação feriria a Constituição de 1988 no tocante ao respeito às peculiaridades regionais e locais. A esse respeito, o caput do artigo 26 da lei 9.394 de 20 de dezembro de 1996 preceitua:

Os currículos do ensino fundamental e médio devem ter uma base nacional comum a ser complementada, em cada sistema de ensino e estabelecimento escolar, por uma parte diversificada, exigida pelas características regionais e locais da sociedade, da cultura da economia e da clientela. (BRASIL, 1996, art. 26).

O veto se justifica, portanto, pelo entendimento de que o Artigo 26 A, § $3^{\circ}$ contrariava a liberdade garantida por lei aos estabelecimentos e sistemas de ensino de escolher sua parte diversificada do currículo com base em sua realidade e necessidades locais.

Artigo 79-A - O veto a este artigo que tratava dos cursos de capacitação para professores estipulando a participação de entidades do movimento afro-brasileiro, das universidades e de outras instituições de pesquisa pertinentes a temática africana ocorreu porque a Lei 9394 de 1996 não disciplina, nem tampouco faz menção, em nenhum de seus artigos, a cursos de capacitação de professores. O artigo 79-A, portanto, estaria rompendo com a unidade do conteúdo da Lei de Diretrizes e Bases da Educação Nacional e contrariando norma de interesse público, conforme Lei complementar $n^{\circ}$ 95, de 26 de fevereiro de 1998, onde foi estabelecido que as leis não poderiam conter matéria estranha ao seu objeto (art. ' inciso II). 


\subsection{A PROMULGAÇÃO DA LEI 10.639/2003}

A assinatura de compromissos internacionais e o esforço empregado pelo Estado em cumpri-los impulsionaram a viabilização de discussões que tratavam no âmbito do Congresso Nacional as condições sociais e econômicas da população negra no Brasil e uma maior atenção às reivindicações históricas do Movimento Negro, até então historicamente ignoradas e proteladas pelo Estado. O quadro abaixo, extraído do texto: Implementação da Lei 10.639/2003 - competências, habilidades e pesquisas para a transformação social, de autoria dos pesquisadores: Marco Antonio Bettine de Almeida e Lívia Pizauro Sanchez apresenta nove políticas que regulamentam a Lei 10.639/2003, sendo quatro relacionadas à criação de órgãos para atuação na área da igualdade racial, dos quais dois têm a função de realizar intervenções especificamente no campo educacional. Três leis contemplam os conteúdos da Lei 10.639/2003 e três documentos explicam e justificam essa mesma lei, indicando os caminhos para sua implementação, conforme o quadro a seguir:

Quadro 3 - Políticas Públicas de implementação da Lei 10.639/2003 - Regulamentação:

\begin{tabular}{|l|l|l|}
\hline Política & Objetivos & Ações \\
\hline $\begin{array}{l}\text { Criação da Secretaria de } \\
\text { Políticas de Promoção da } \\
\text { Igualdade Racial }\end{array}$ & $\begin{array}{l}\text { Formular, coordenar e } \\
\text { articular políticas, } \\
\text { diretrizes e programas. } \\
\text { Implementar legislações } \\
\text { para promoção da } \\
\text { igualdade racial. }\end{array}$ & \\
\hline $\begin{array}{l}\text { Eriação da Secretaria de } \\
\text { Educação Continuada, }\end{array}$ & $\begin{array}{l}\text { Efetivar Políticas } \\
\text { Públicas de valorização } \\
\text { da diversidade. }\end{array}$ & \\
\hline
\end{tabular}




\begin{tabular}{|c|c|c|}
\hline Parecer 003/2004 & $\begin{array}{l}\text { Orientar a } \\
\text { implementação da Lei } \\
\text { 10.639/2003. }\end{array}$ & $\begin{array}{l}\text { Atribuição de competências; determinação de } \\
\text { estratégias para formação; inclusão da Educação } \\
\text { Infantil, do Ensino Superior e de instituições de } \\
\text { formação inicial e continuada na na pera da Lei; } \\
\text { responsabilidade pela implementação da Le de } \\
\text { incentivo à produção e à divulgação de livros, } \\
\text { materiais didáticos e experiências pedagógicas; } \\
\text { destaque à importância do Movimento Negro e } \\
\text { dos Núcleos de Estudos Afro-Brasileiros. }\end{array}$ \\
\hline $\begin{array}{l}\text { Diretrizes Curriculares } \\
\text { Nacionais para a Educação das } \\
\text { Relações Étnico Raciais e para o } \\
\text { Ensino de História e Cultura } \\
\text { Afro-brasileira e Africana } \\
\text { (Resolução 001/04) }\end{array}$ & $\begin{array}{l}\text { Orientar a } \\
\text { implementação da Lei } \\
\text { 10.639/2003. }\end{array}$ & Distribuição de exemplares para professores(as). \\
\hline $\begin{array}{l}\text { Fórum Intergovernamental de } \\
\text { Promoção da Igualdade Racial }\end{array}$ & $\begin{array}{l}\text { Estimular a } \\
\text { implementação da } \\
\text { Política Nacional de } \\
\text { Promoção da Igualdade } \\
\text { Racial. }\end{array}$ & $\begin{array}{l}\text { Filiação de } 669 \text { municípios Assistência financeira } \\
\text { para formação de professores e aquisição de } \\
\text { material didático no Ensino Fundamental, nas } \\
\text { capitais da Federação, no Distrito Federal e nos } \\
\text { municípios filiados ao Fórum. }\end{array}$ \\
\hline $\begin{array}{l}\text { Comissão Técnica Nacional de } \\
\text { Diversidade para assuntos } \\
\text { relacionados à educação dos } \\
\text { afro-brasileiros }\end{array}$ & $\begin{array}{l}\text { Elaborar, acompanhar, } \\
\text { analisar e avaliar } \\
\text { Políticas Públicas } \\
\text { relacionadas à Lei } \\
10.639 / 2003 \text {. }\end{array}$ & \\
\hline $\begin{array}{l}\text { Política Nacional de Formação } \\
\text { de Profissionais do Magistério } \\
\text { da Educação Básica }\end{array}$ & $\begin{array}{l}\text { Organizar a formação } \\
\text { inicial e continuada. }\end{array}$ & $\begin{array}{l}\text { Questões relacionadas à Lei 10.639/2003 e suas } \\
\text { regulamentações. }\end{array}$ \\
\hline
\end{tabular}




\begin{tabular}{|c|c|c|}
\hline $\begin{array}{l}\text { Plano Nacional de } \\
\text { Implementação das Diretrizes } \\
\text { Curriculares Nacionais da } \\
\text { Educação das Relações Étnico } \\
\text { Raciais e para o Ensino de } \\
\text { História e Cultura Afro- } \\
\text { brasileira e Africana }\end{array}$ & $\begin{array}{l}\text { Fortalecer e } \\
\text { institucionalizar as } \\
\text { orientações que já } \\
\text { existiam. }\end{array}$ & $\begin{array}{l}\text { Estabelecimento de metas e estratégias para a } \\
\text { execução da Lei 10.639/2003; delimitação de } \\
\text { responsabilidades dos atores governamentais; } \\
\text { proposição de ações de formação de professores; } \\
\text { sensibilização de gestores; e produção de } \\
\text { material didático. }\end{array}$ \\
\hline Estatuto da Igualdade Racial & $\begin{array}{l}\text { Proteger os direitos da } \\
\text { população negra. }\end{array}$ & $\begin{array}{l}\text { Reafirmação da obrigatoriedade do estudo da } \\
\text { História Geral da África e da História da } \\
\text { população negra no Brasil Determinação de que o } \\
\text { Poder Executivo fomente a formação inicial e } \\
\text { continuada dos professores e a elaboração de } \\
\text { material didático específico Incentivo à formação } \\
\text { de grupos, núcleos e centros de pesquisa nos } \\
\text { programas de Pós-Graduação e à inclusão de } \\
\text { temas relativos à pluralidade étnica e cultural nos } \\
\text { currículos dos cursos de formação de professores. }\end{array}$ \\
\hline
\end{tabular}

Fonte: (PRÓ.POSIÇÕES OLINE, 2017)

Num esforço de caráter contínuo e que contou com a efetiva participação do Movimento Negro, as políticas públicas citadas no quadro foram implementadas. Esse processo durou mais de uma década e promoveu uma série de encontros e debates que contaram com a participação de entidades governamentais e não governamentais cuja composição fora feita principalmente por lideranças políticas e intelectuais que se dedicam a causa Negra. Dentre elas destaca-se a atuação das Professoras e Militantes Petronilha Beatriz Gonçalves e Silva ${ }^{38}$ e Nilma Lino dos Santos ${ }^{39}$.

\footnotetext{
${ }^{38}$ Por indicação do Movimento Negro, Petronilha Beatriz Gonçalves e Silva, foi conselheira da Câmara de Educação Superior do Conselho Nacional de Educação, mandato 2002-2006. Nesta condição foi relatora do Parecer CNE/CP 3/2004 que estabelece as Diretrizes Curriculares Nacionais para a Educação das Relações Étnico-Raciais e para o Ensino de História e Cultura Afro-Brasileira e Africana e participou da relatoria do Parecer CNE/CP 3/2005 relativos às diretrizes curriculares Nacionais para o curso de Pedagogia. (UNIVERSIDADE FEDERAL DE SÃO CARLOS, 2017).
} 


\subsection{A LEI 10.639/2003 E AS ALTERAÇÕES CONTIDAS NA LEI 11.645/2008}

A Lei $\mathrm{n}^{\circ} 11.645$ de 10 de março de 2008, publicada no diário oficial em 11 de março de 2008, trata da mesma orientação contida na Lei 10.639/2003 incluindo, além da obrigatoriedade do ensino das culturas africanas e afro brasileiras nos currículos de educação básica, a temática indígena. Ela altera, a Lei n 9.394 de 20 de dezembro de 1996, até então modificada pela Lei $\mathrm{n}^{\mathrm{o}} 10.639$ de 9 de janeiro de 2003, e: [...] "estabelece as diretrizes e bases da educação nacional, para incluir no currículo oficial da rede de ensino a obrigatoriedade da temática História e Cultura Afro-Brasileira e Indígena.” (BRASIL, 2008).

A alteração referida tornou obrigatório o ensino da história e da cultura afro-brasileira e indígena nos estabelecimentos de ensino fundamental e ensino médio tanto público quanto privado, e, estabeleceu, no Artigo primeiro, que altera o Artigo 26 da Lei $\mathrm{n}^{\circ}$ 9.394/96 parágrafo $1^{\circ}$ e $2^{\circ}$ que:

$\S 1^{\circ} \mathrm{O}$ conteúdo programático a que se refere este artigo incluirá diversos aspectos da história e da cultura que caracterizam a formação da população brasileira, a partir desses dois grupos étnicos, tais como o estudo da história da África e dos africanos, a luta dos negros e dos povos indígenas no Brasil, a cultura negra e indígena brasileira e o negro e o índio na formação da sociedade nacional, resgatando as suas contribuições nas áreas social, econômica e política, pertinentes à história do Brasil. $\S 2^{\circ}$ Os conteúdos referentes à história e cultura afro-brasileira e dos povos indígenas brasileiros serão ministrados no âmbito de todo o currículo escolar, em especial nas áreas de educação artística e de literatura e história brasileira. (BRASIL, 2008).

A alteração trazida pela lei 11.645/2008 acrescenta, portanto, a obrigatoriedade do ensino da história e cultura afro-brasileira, o ensino da história e cultura indígena, como grupos étnicos que compõem a formação da sociedade nacional. Essas transformações implicam em ações que viabilizem a implementação e efetivação dessas alterações no currículo escolar, mais especificamente no âmbito do ensino de história e literatura brasileira e educação artística. Considera-se as Leis $n^{\circ}$ 10.639/2003 e $n^{\circ} 11.645 / 2008$, não apenas como instrumentos de orientação para o combate à discriminação, pois elas são também leis afirmativas, reconhecem a escola como lugar de formar cidadãos, e afirmam a relevância da mesma promover a valorização das matrizes culturais brasileiras. São instrumentos legais que orientam as instituições educacionais quanto a suas atribuições. Entretanto, ao considerarmos

\footnotetext{
${ }^{39}$ Nilma Lino dos Santos possui uma ativa e reconhecida luta contra o racismo no Brasil. Em 2 de outubro de 2015 foi nomeada pela presidente Dilma Rousseff para ocupar o novo Ministério das Mulheres, da igualdade Racial e dos Direitos Humanos e parte das atribuições da Secretaria - Geral. Permaneceu no cargo até o dia do afastamento da Presidenta Dilma pelo Senado Federal. (SECRETARIA NACIONAL DE PROMOÇÃO DA IGUALDADE RACIAL, 2017).
} 
que a adoção ainda não se universalizou no sistema brasileiro de ensino, há a necessidade de fortalecer e institucionalizar essas orientações. Segundo Reis:

A existência de leis e políticas de ação afirmativa não basta para desenvolver atitudes e hábitos que garantam a construção do respeito às diferenças. Aqueles só serão alcançados se houver predisposição, por parte da sociedade, para provocar mudanças (REIS, 2009, p. 60).

O quadro a seguir, elaborado a partir de informações disponíveis no portal do MEC Ministério da Educação, na Internet, apresenta uma relação de Pareceres e Resoluções elaboradas a partir da promulgação da lei 10.639/2003 e uma síntese de seus objetivos.

Quadro 4 - Pareceres e Resoluções sobre Educação das Relações Étnico-Raciais

\begin{tabular}{|l|l|l|}
\hline $\begin{array}{l}\text { Pareceres e } \\
\text { Resoluções }\end{array}$ & Data & Objetivos \\
\hline $\begin{array}{l}\text { Parecer } \\
\text { CNE/CP - N. } \\
3\end{array}$ & $\begin{array}{l}10 \text { de março } \\
\text { de } 2004\end{array}$ & $\begin{array}{l}\text { Regulamenta a alteração trazida à Lei 9394/96 de Diretrizes e } \\
\text { Bases da Educação Nacional, pela Lei 10.639/200, que } \\
\text { estabelece a obrigatoriedade do ensino de História e Cultura } \\
\text { Afro-Brasileira e Africana na Educação Básica. (MEC. } \\
\text { PARECER CNE/CP - No. 3) }\end{array}$ \\
\hline $\begin{array}{l}\text { Resolução } \\
\text { CNE/CP - N. } \\
1\end{array}$ & $\begin{array}{l}17 \text { de junho } \\
\text { de } 2004\end{array}$ & $\begin{array}{l}\text { Institui Diretrizes Curriculares Nacionais para a Educação das } \\
\text { Relações Étnico-Raciais e para o Ensino de História e Cultura } \\
\text { Afro-Brasileira e Africana. (MEC. PARECER CNE/CP - No } \\
\text { 2) }\end{array}$ \\
\hline $\begin{array}{l}\text { Parecer } \\
\text { CNE/CEB - } \\
\text { N. 2 }\end{array}$ & $\begin{array}{l}31 \\
\text { janeiro de }\end{array}$ & $\begin{array}{l}\text { Parecer quanto à abrangência das Diretrizes Curriculares } \\
\text { Nacionais para a Educação das Relações Étnico-Raciais e para } \\
\text { o Ensino de História e Cultura Afro-Brasileira e Africana. } \\
\text { (MEC. PARECER CNE/CEB - No. 2) }\end{array}$ \\
\hline $\begin{array}{l}\text { Parecer } \\
\text { CNE/CEB - } \\
\text { N. 15 }\end{array}$ & $\begin{array}{l}01 \\
\text { setembro de } \\
2010\end{array}$ & $\begin{array}{l}\text { Orientações para que a Secretaria de Educação do Distrito } \\
\text { Federal se abstenha de utilizar material que não se coadune } \\
\text { com as políticas públicas para uma educação antirracista. }\end{array}$ \\
\hline $\begin{array}{l}\text { Parecer } \\
\text { CNE/CEB }- \\
\text { N.16 }\end{array}$ & $\begin{array}{l}01 \text { setembro } \\
\text { de 2010 }\end{array}$ & $\begin{array}{l}\text { Denúncia de racismo na Escola Estadual Delmira Ramos dos } \\
\text { Santos, localizada no Bairro Coophavilla II, Município de } \\
\text { Campo Grande, MS. }\end{array}$ \\
\hline $\begin{array}{l}\text { Parecer } \\
\text { CNE/CEB - } \\
\text { N. 06 }\end{array}$ & $\begin{array}{l}01 \text { de junho } \\
\text { de 2011 }\end{array}$ & $\begin{array}{l}\text { Reexame do Parecer CNE/CEB no 15/2010, com orientações } \\
\text { para que material utilizado na Educação Básica se coadune } \\
\text { com as políticas públicas para uma educação antirracista. }\end{array}$ \\
\hline
\end{tabular}

Fonte: (BRASIL, 2018).

A obrigatoriedade da inclusão do ensino das culturas africanas e afro brasileiras nos currículos da educação básica do país instituída pela Lei 10.639/2003 exigiu alterações no texto legal que compõe as Diretrizes e Bases de Educação Nacional, Lei 9394/96. Essas modificações foram pautadas no cumprimento aos Art. 5\%, I; Art. 206, I, Art. 210; $\$ 1^{\text {o }}$ do Art. 242; Art. 215 e Art. 216 da Constituição Federal, assim como dos Art. 26, 26A e 79B da Lei 9.394/96 que: 
[...] asseguram o direito à igualdade de condições de vida e de cidadania, assim como garantem igual direito às histórias e culturas que compõem a nação brasileira, além do direito de acesso às diferentes fontes da cultura nacional a todos brasileiros. (BRASIL, 2004, p.1).

Regulamentadas pela Resolução de número 01, de 17 de junho de 2004, as modificações ocorridas no texto das Diretrizes e Bases de Educação Nacional, Lei 9394 de 1996 deu início ao processo de construção de uma série de documentos legais cujo objetivo foi criar a efetiva possibilidade de cumprimento da Legislação 10.639/2003 nas escolas de educação básica do país e adota sempre um discurso que justifica a legitimidade da Lei e da importância histórica da adoção de um currículo que contemple a valorização das contribuições africanas para a construção do Brasil.

Em situações mais específicas, como é o caso do Parecer do Conselho Nacional de Educação (CNE) e do Conselho de Educação Básica (CEB) - n. 16, de 01 setembro de 2010, onde é tratada a denúncia de racismo em uma Escola Estadual de Campo Grande, Mato Grosso do Sul, observa-se a incisiva orientação para que a Secretaria Estadual de Educação desse Estado apoie e acompanhe a Escola, onde teriam ocorrido os fatos, no desenvolvimento de iniciativas pedagógicas de combate a prática de racismo.

São observadas também, orientações quanto à utilização de materiais que não estejam de acordo com as políticas públicas para uma educação antirracista. Como é o caso do Parecer CNE/CEB - N. 15, de 01 de setembro de 2010. O documento trata de uma denúncia sobre a utilização inadequada da obra de Monteiro Lobato intitulada Caçadas de Pedrinho (1954) cujo teor foi citado pelo autor da denúncia como "racista".

De acordo com o Parecer, a denúncia realizada em torno das ilustrações contidas na obra de Monteiro Lobato em sua $3^{\mathrm{a}}$ edição, $1^{\mathrm{a}}$ reimpressão, ano de 2009 e quanto a expressões de cunho racista que estariam nelas presentes:

[...] a crítica realizada pelo requerente foca de maneira mais específica a personagem feminina e negra Tia Anastácia e as referências aos personagens animais tais como urubu, macaco e feras africanas. Estes fazem menção revestida de estereotipia ao negro e ao universo africano, que se repete em vários trechos do livro analisado. (BRASIL, 2010, p.2).

Observa-se que o autor da denúncia faz uso da Legislação antirracista para embasar seu pedido de providências e que sua denúncia resulta na construção de um Parecer onde são reforçadas as orientações para o atendimento ao cumprimento da legislação já existente e da criação de outras mais que, de modo mais preciso, oriente o trabalho docente para um ensino também pautado no combate ao racismo. A Secretaria Especial de Promoção de Políticas de Igualdade Racial (SEPPIR) e a Secretaria de Educação Continuada, Alfabetização e 
Diversidade (SECAD) em parecer quanto a denúncia, reforça a necessidade de se conduzir com atenção a escolha de materiais didáticos e mais especificamente as chamadas obras Literárias Clássicas e dentre outras orientações observa que:

[...] cabe à Coordenação-Geral de Material Didático do MEC cumprir com os critérios por ela mesma estabelecidos na avaliação dos livros indicados para o PNBE, de que os mesmos primam pela ausência de preconceitos, estereótipos, não selecionando obras clássicas ou contemporâneas com tal teor. (BRASIL, 2010, p.5).

Em linhas gerais, nota-se um esforço institucional, por meio específico da Secretaria de Educação Continuada, Alfabetização e Diversidade (SECAD) em atender através de políticas de orientação e formação, demandas que pudessem consolidar a efetiva implementação da Legislação, em conformidade com uma de suas finalidades de criação que é a de [...] "Formulação, coordenação e articulação de políticas e diretrizes para a promoção da igualdade racial”. (SECRETARIA ESPECIAL DE PROMOÇÃO DE POLÍTICAS DE IGUALDADE RACIAL, 2017).

\subsection{AS DIRETRIZES CURRICULARES NACIONAIS PARA O ENSINO DAS RELAÇÕES ÉTNICO RACIAIS E PARA O ENSINO DE HISTÓRIA E CULTURA AFRO- BRASILEIRA E AFRICANA}

A Lei 10.639/2003, ao mesmo tempo em que indicou a inclusão obrigatória no currículo oficial da Rede de Ensino da temática "História e Cultura Afro-Brasileira", no ano de 2003, gerou também uma série de ações do governo brasileiro para sua implementação. Nesse sentido, em 2004 o Conselho Nacional de Educação instituiu as Diretrizes Curriculares para a Educação das Relações Étnico-Raciais e para o Ensino de História e Cultura AfroBrasileira e Africana, através do Parecer CNE/CP - N. 3 de 10 de março de 2004 e da Resolução CNE/CP - N. 1 de 17 de junho de 2004 que detalham os direitos e obrigações dos órgãos federativos frente à implementação da Lei ${ }^{\circ}$ 10.369/03 e justificam a necessidade do ensino da história afro-brasileira e africana pela comprovada existência de desigualdades sociais entre negros e brancos atestadas em estudos publicados, produzidos por órgãos oficiais, bem como por pesquisadores na área de educação, afirmando haver razões históricas e sociais suficientes para que as diretrizes indiquem ações efetivas em todas as instâncias do sistema educacional.

Por seu caráter normativo, o texto procura: 
[...] regular caminhos a partir de determinações iniciais que objetivam oferecer referências e critérios para a implantação de ações, de avaliação dessas ações assim como de reformulação dessas quando necessário (BRASIL, 2010, p. 16).

A obra apresenta uma coletânea de textos, com autorias diversas que são divididas em seções que abordam cada uma das diferentes etapas da Educação Básica, Superior e Educação Quilombola.

Com um discurso que ressalta a demanda por políticas de reparação e de reconhecimento e valorização da história, cultura e identidade no contexto educacional advindas da população afrodescendente, o texto chama o Estado ao seu dever constitucional de promover e incentivar políticas de reparação.

A contextualização de desigualdades sociais também é impressa no texto o que é feito a partir de dados estatísticos que procuram evidenciá-las.

Sua criação foi pautada em princípios que orientam todo o documento e que se apresentam também na Legislação que trata do ensino das Culturas Africanas e Afro brasileiras. Esses princípios foram abaixo transcritos:

\section{Consciência Política E Histórica Da Diversidade}

À igualdade básica de pessoa humana como sujeito de direitos;

À compreensão de que a sociedade é formada por pessoas que pertencem a grupos étnico-raciais distintos, que possuem cultura e história próprias, igualmente valiosas e que em conjunto constroem, na nação brasileira, sua história;

Ao conhecimento e à valorização da história dos povos africanos e da cultura afrobrasileira na construção histórica e cultural brasileira; Diretrizes Curriculares Nacionais para a Educação das Relações Étnico-Raciais e para o Ensino de História e Cultura Afro-Brasileira e Africana;

À superação da indiferença, injustiça e desqualificação com que os negros, os povos indígenas e também as classes populares às quais os negros, no geral, pertencem, são comumente tratados;

À desconstrução, por meio de questionamentos e análises críticas, objetivando eliminar conceitos, ideias, comportamentos veiculados pela ideologia do branqueamento, pelo mito da democracia racial, que tanto mal fazem a negros e brancos;

À busca, da parte de pessoas, em particular de professores não familiarizados com a análise das relações étnico-raciais e sociais com o estudo de história e cultura afrobrasileira e africana, de informações e subsídios que lhes permitam formular concepções não baseadas em preconceitos e construir ações respeitosas;

Ao diálogo, via fundamental para entendimento entre diferentes, com a finalidade de negociações, tendo em vista objetivos comuns, visando a uma sociedade justa. (BRASIL, 2004, p.18-19).

Fortalecimento de identidades e de direitos

O desencadeamento de processo de afirmação de identidades, de historicidade negada ou distorcida; 
O rompimento com imagens negativas forjadas por diferentes meios de comunicação, contra os negros e os povos indígenas;

Os esclarecimentos a respeito de equívocos quanto a uma identidade humana universal;

O combate à privação e violação de direitos;

A ampliação do acesso a informações sobre a diversidade da nação brasileira e sobre a recriação das identidades, provocada por relações étnico-raciais;

As excelentes condições de formação e de instrução que precisam ser oferecidas, nos diferentes níveis e modalidades de ensino, em todos os estabelecimentos, inclusive os localizados nas chamadas periferias urbanas e nas zonas rurais.

(BRASIL, 2004 p.19).

Ações educativas de combate ao racismo e a discriminações

A conexão dos objetivos, estratégias de ensino e atividades com a experiência de vida dos alunos e professores, valorizando aprendizagens vinculadas Diretrizes Curriculares Nacionais para a Educação das Relações Étnico-Raciais e para o Ensino de História e Cultura Afro-Brasileira e Africana às suas relações com pessoas negras, brancas, mestiças, assim como as vinculadas às relações entre negros, indígenas e brancos no conjunto da sociedade;

A crítica pelos coordenadores pedagógicos, orientadores educacionais, professores, das representações dos negros e de outras minorias nos textos, materiais didáticos, bem como providências para corrigi-las;

Condições para professores e alunos pensarem, decidirem, agirem, assumindo responsabilidade por relações étnico-raciais positivas, enfrentando e superando discordâncias, conflitos, contestações, valorizando os contrastes das diferenças;

Valorização da oralidade, da corporeidade e da arte, por exemplo, como a dança, marcas da cultura de raiz africana, ao lado da escrita e da leitura;

Educação patrimonial, aprendizado a partir do patrimônio cultural afro-brasileiro, visando a preservá-lo e a difundi-lo;

O cuidado para que se dê um sentido construtivo à participação dos diferentes grupos sociais, étnico-raciais na construção da nação brasileira, aos elos culturais e históricos entre diferentes grupos étnico-raciais, às alianças sociais;

(BRASIL, 2004, p.19).

Os princípios orientadores apresentados pelo documento completam um discurso que se diz não pretender ditar o que deve ser feito ou não pelos educadores e sistemas de ensino, colocando-se como uma fonte de estudos onde são observados caminhos e possibilidades que objetivam mudanças nos processos educativos no tocante às relações étnico-raciais dentro e fora das escolas. As Diretrizes Curriculares Nacionais para a Educação das Relações ÉtnicoRaciais e para o Ensino de História e Cultura Afro-Brasileira e Africana são apresentadas como parte de um percurso normatizador decorrente da aprovação da Lei $n^{\circ}$ 10.639/03 que, junto a outras iniciativas, objetiva possibilitar a efetivação das temáticas africana nos currículos escolares contribuindo assim para o fim da discriminação racial. 


\section{A QUESTÃO RACIAL NOS LIVROS DIDÁTICOS E OS IMPACTOS DA LEI 10.639/2003 NA PRODUÇÃO DE LIVROS DIDÁTICOS NO BRASIL}

Objeto de análises críticas e reivindicações históricas, o livro didático foi apontado pelos movimentos sociais, especialmente pelo Movimento Negro, como disseminador de preconceitos e discriminações raciais que contribuíram para a manutenção de desigualdades sociais entre brancos e negros.

Enquanto recurso pedagógico amplamente utilizado nas escolas brasileiras para veicular conhecimento, o livro didático tem um grande alcance na transmissão de conhecimentos e formação de valores, já que participa na estruturação do ensino em grande parte das escolas brasileiras. A forma como neles se encontram selecionados e organizados os saberes valorizados pela cultura escolar evidenciam, como partes integrantes dos discursos veiculados reproduzem uma série de representações que circulam na sociedade sobre as distinções sociais.

O exame histórico dos processos de avaliação e da legislação criado pelo Governo Federal com o intuito de regular a produção de livros didáticos no país pode demonstrar que as questões relacionadas ao preconceito e a discriminação racial reproduzidas nesses materiais não foram objetos de preocupação para o Estado brasileiro, mesmo com a reivindicação de outras instâncias que construíram um olhar mais cuidadoso sobre a forma como estas questões estiveram postas nestes materiais.

O presente estudo apresentará uma síntese das formas de avaliação e controle exercidas pelo Estado sobre a produção desses materiais e dos discursos do Movimento Negro acerca do preconceito racial, além de identificar os possíveis impactos da Lei 10.639/2003 sobre a produção didática.

\subsection{O LIVRO DIDÁTICO E A EDUCAÇÃO NO BRASIL}

A utilização de manuais e livros didáticos como suporte pedagógico para o ensino trata-se de uma prática bastante antiga e tradicional na educação brasileira. Segundo Circe Bittencourt (1993), a produção desses materiais teve início no Brasil em 1808, quando a Imprensa Régia produziu os primeiros manuais para os cursos criados por D. João VI no país.

Ao longo dos anos, a produção desse segmento editorial sofreu diversas modificações e ganhou cada vez mais espaço no cenário educacional brasileiro, resultando numa 
movimentação anual milionária para o mercado editorial. Na década de 1990, por exemplo, foram produzidos cerca de três bilhões de livros com média anual de 300 milhões de exemplares.

Segundo dados publicados pelo Ministério da Educação (MEC) e disponíveis eletronicamente em sua home page, a produção de obras didáticas aderidas pelo Programa Nacional do Livro Didático (PNLD), do Fundo Nacional de Desenvolvimento da Educação (FNDE), representou, em 2009, 88\% do movimento do mercado editorial brasileiro. O levantamento foi feito pela autarquia com base em dados da Associação Brasileira de Editores de Livros Escolares (ABRELIVROS), e leva em conta os 115 milhões de obras distribuídas a 36,6 milhões de estudantes da educação básica pública, além de 3 milhões de títulos voltados à alfabetização de jovens e adultos. No mesmo período, o mercado privado adquiriu 15 milhões de exemplares.

As políticas educacionais adotadas pelo Estado brasileiro provocaram um movimento contínuo de adaptação do setor editorial, que buscou adequar seus produtos às normativas governamentais estabelecidas pelo Programa Nacional do Livro Didático. Com suas demandas atendidas pelas editoras, o Governo Federal tornou-se o maior consumidor desse segmento.

A compra de livros didáticos a partir do Programa Nacional do Livro Didático PNLD, realizada com recursos públicos exclusivamente destinados a essa finalidade, justificase pela meta de universalização de distribuição do livro didático adotado pelo Ministério da Educação MEC/PNLD em cumprimento ao inciso VII do Artigo 208 da Constituição Federal de 1988:

O dever do Estado com a Educação será efetivado mediante a garantia de atendimento a educação, no Ensino Fundamental, através de programas suplementares de material didático, escolar, transporte, alimentação e assistência à saúde. (BRASIL, 1988, art. 208).

O quadro, no anexo 1, reproduzido a partir da obra: Racismo em livros didáticos: Estudo sobre negros e brancos em livros didáticos, de autoria de Paulo Vinícius Baptista Silva (2008), apresenta uma síntese das Legislações voltadas às políticas do livro didático no Brasil entre os anos de 1938 e 1996. Os dados nele presentes demonstram que as iniciativas do Estado brasileiro em relação à produção desses materiais didáticos tiveram como característica fundamental a regulação e o controle sobre a produção, priorizando, muitas vezes, aspectos financeiros, logísticos e político-ideológico. 
Nos últimos itens da tabela, que tratam da extinção do Fundo de Assistência ao Estudante (FAE), podem-se presumir algumas ações vinculadas à preocupação com a verificação da qualidade dos conteúdos, quando o texto faz menção a catálogos com a classificação dos livros didáticos avaliados pelo Estado para auxiliar os professores na escolha desses materiais.

\subsection{A AVALIAÇÃO DE LIVROS DIDÁticos E A PREOCUPAÇÃO COM A DISCRIMINAÇÃO RACIAL}

A questão da qualidade dos conteúdos presentes nos livros didáticos e, especificamente, a forma como a questão racial era abordada nesses materiais parece não ter sido uma preocupação do Governo Brasileiro até o fim da década de 1980. Essas questões foram muito mais debatidas por grupos sociais preocupados com a educação e com os valores sociais disseminados pelas escolas do que pelo Estado.

Entre os anos de 1993 e 1994, com a publicação da Portaria de número 1.230, de 05 de agosto, o Ministério da Educação - MEC, iniciou um processo de adoção de critérios gerais mais claros e objetivos para a avaliação pedagógica de livros didáticos no país, especialmente para as áreas de Português, Matemática, Estudos Sociais e Ciências, dirigidos a ensino primário - de $1^{\mathrm{a}}$ a $4^{\mathrm{a}}$ séries (BRASIL, 1994).

Ainda assim, segundo Silva P.V.B (2008), as avaliações realizadas pelos grupos de trabalho instituídos foram feitas de forma independente por cada grupo e os critérios de avaliação distintos para cada disciplina escolar. Ainda segundo o autor, foram encontrados indícios de que as equipes de avaliação das áreas de Matemática, Estudos Sociais e Português levaram em consideração aspectos levantados por pesquisas sobre preconceito racial presentes em livros didáticos. Tais equipes apresentaram pontos em que buscaram a apreensão de formas implícitas de discriminação. Essas análises se preocuparam, por exemplo, com a ausência e proporção de personagens não brancos nos textos de Matemática e Estudos Sociais e ilustrações nos materiais de Matemática e Língua Portuguesa e, por fim, exercícios e atividades estereotipadas de personagens negros sempre no papel de empregados domésticos, cozinheiros ou pedreiros nos livros de matemática.

É importante ressaltar que o processo avaliativo empregado pelo Ministério da Educação em relação à questão da discriminação presente nos livros didáticos, era superficial, problema agravado pela não adoção de um padrão único de critérios de avaliação pelos 
grupos de trabalho delas encarregados. Isso fez com que alguns materiais fossem avaliados acerca da temática, enquanto outros, não.

Os grupos de trabalho encarregados do processo avaliativo apresentaram, em virtude de pressão midiática, uma síntese sobre os principais erros encontrados nos livros didáticos e quatro recomendações ao Ministério da Educação. Foram elas:

\footnotetext{
Estabelecimento de um programa mínimo obrigatório em todas as disciplinas que constituem o currículo do $1^{\circ}$ Grau;

Instituição na FAE de uma instância de avaliação do livro didático;

Campanha sistemática de divulgação dos resultados e avaliações d livro didático nas quatro séries iniciais do $1^{\circ} \mathrm{Grau}$;

Incentivo a grupos qualificados de produção de livros didáticos (BRASIL, 1994, p. 103-104).
}

De acordo com Silva JR (1998), em dezembro de 1995, o MEC apresentou às editoras dois critérios eliminatórios que passariam a ser adotados para a aprovação e reprovação dos livros didáticos. Eram eles: [...] "os livros não poderiam expressar preconceito de origem, raça, sexo, cor, idade ou quaisquer outras formas de discriminação, assim como não poderiam induzir ao erro ou conter erros graves relativos ao conteúdo da área, como erros conceituais" (SILVA JR, 1998, p. 114).

Em 1996, tiveram início avaliações sistemáticas e os livros foram avaliados por equipes de especialistas das mesmas quatro disciplinas escolares avaliadas anteriormente: Português, Matemática, Estudos Sociais e Ciências de $1^{\mathrm{a}}$ a $4^{\mathrm{a}}$ séries. Esses materiais foram avaliados em quatro níveis: "recomendados", "recomendados, os quais, apesar disso, com ressalvas", "não recomendados" e "excluídos". Os professores receberam um guia contendo os livros recomendados e recomendados com ressalvas e um catálogo com os livros não recomendados, os quais, apesar disso, também poderiam ser escolhidos.

Em 1997, as categorias passaram a ser representadas graficamente por estrelas e, em 1999, acrescentaram-se aos critérios de exclusão as “incorreções e incoerências metodológicas". Nesse ano, os critérios eliminatórios passaram a ser três:

- Correção dos conceitos e informações básicas;

- Correção e pertinência metodológica;

- Contribuição para a construção da cidadania.

O terceiro item dos conteúdos que aborda a questão da construção da cidadania foi assim redigido:

“O livro didático não poderá veicular preconceitos de origem, cor, condição econômica - social, etnia, gênero e qualquer outra forma de discriminação, fazer doutrinação religiosa, desrespeitando o caráter leigo do ensino público" (BRASIL, 1999, p. 15-16). 
É possível perceber que a mudança do termo "cor/raça" para "cor/etnia" registrada nos critérios de avaliação em 1999, não foi acompanhada por qualquer justificativa ou explicação.

Em relação aos aspectos visuais, os guias de livros didáticos trazem uma série de indicações, entre elas a de que estes "principalmente não deverão expressar, induzir ou reforçar estereótipos" (BRASIL, 1997, p. 14).

Em 2002 a indicação passa ser mais explícita: "principalmente, devem reproduzir a diversidade étnica da população brasileira e não poderão expressar, induzir ou reforçar estereótipos (BRASIL, 2001, p. 28)

Para Silva, nos critérios de avaliação do livro didático, não é perceptível qualquer preocupação com o discurso racista que vá além do genérico. "Manifesta expressão do discriminatório" (SILVA, P.V.B, 2008, p.119).

\subsection{A REPRESENTAÇÃO DO NEGRO NOS LIVROS DIDÁTICOS E A REPRESENTAÇÃO DOS MOVIMENTOS SOCIAIS NO PROGRAMAS DE AVALIAÇÃO DO PNLD}

A representação dos negros em livros didáticos configura-se como uma problemática que possibilita uma importante reflexão acerca dos preconceitos raciais que permanecem e se renovam na sociedade brasileira à medida que são reproduzidos continuamente, seja de maneira explícita, ou implícita, em textos e imagens utilizadas nas práticas de ensino e conteúdos ensinados nas escolas.

As afirmações e imagens depreciativas presentes nos livros didáticos podem dificultar a construção de uma identidade positiva de uma criança negra em relação a sua origem. A esse respeito, Silva afirmou:

[...] Isso tem um impacto sobre a construção da identidade dos educandos de ascendência africana, indígena e mestiça, que não encontram referências positivas a sua origem, a sua cultura e a sua história, omitida ou mostrada de maneira caricatural, estereotipada e folclorizada na escola. (SILVA, A.C., 1995, p. 135).

A problemática abordada por este autor, já era discutida pelo movimento negro desde seu início, intensificando-se a partir de sua unificação, na década de 1970, quando já existia um grande engajamento deste segmento na luta pela inserção do negro no espaço escolar e por mudanças na forma como o negro e sua cultura era retratado na escola. 
Fato é que o espaço escolar, assim como os recursos pedagógicos tradicionalmente utilizados para orientar a aprendizagem, reproduziu um conjunto de valores e conhecimentos elitistas e eurocêntricos que silenciavam acerca do valor e da história de povos não brancos, principalmente a dos negros, camada vista como degradada e inferior.

A representação dos negros nos materiais didáticos foi preocupação explícita desde a constituição do Movimento Negro Unificado (MNU), em 1979, quando uma das principais reivindicações era justamente a de:

[...] uma mudança completa na educação escolar de modo a extirpar dos livros didáticos, dos currículos e das práticas de ensino os estereótipos e os preconceitos contra os negros, instilando, ao contrário, a autoestima e o orgulho. (GUIMARÃES, 2002, p. 106).

A principal crítica feita pelo Movimento negro se referiu ao fato de desses materiais reproduzirem valores sociais que mantinham o negro em uma condição social subalterna e estereotipada.

Faz-se notória, no entanto, a total exclusão dos movimentos sociais e especialmente do Movimento Negro, nas avaliações sistemáticas dos livros instituídas pelo Ministério da Educação. Segundo SILVA, P.V.B. (2008) “o movimento negro (ou qualquer outro movimento social) não foi citado como grupo de interesse ou participação no que se refere ao PNLD”. (SILVA, P.V.B., 2008, p. 120).

Excluídos das atividades desenvolvidas pelo Programa Nacional do Livro Didático, os movimentos sociais desenvolveram várias e importantes ações nas décadas de 1980 e 1990, como a realização de encontros e seminários que objetivavam discutir justamente a discriminação racial presentes nesses materiais. Tais ações, mesmo à margem do processo oficial de avaliação, ecoaram, resultando em algumas ações graduais por parte do Ministério da Educação em resposta às demandas apontadas. Num processo lento e gradual o Movimento Negro, assim como outros movimentos sociais, conseguiu explicitar suas insatisfações a respeito da forma como a questão racial era tratada.

No Relatório do Comitê Nacional para a Preparação da participação Brasileira na III Conferência Mundial das Nações Unidas Contra o Racismo, discriminação Racial, Xenofobia e Intolerância, realizada em 09 de setembro de 2001, a crítica e a superação das discriminações sociais foram objeto de preocupação e, nesse momento, foi proposta a revisão dos conteúdos dos livros didáticos visando eliminar estereótipos (OLIVEIRA, 2000, p. 26).

Também foi aprovado neste mesmo momento, um plano de ação que: 
[...] exorta a UNESCO a apoiar os Estados na preparação de materiais didáticos e de outros instrumentos de promoção do ensino, com o intuito de fomentar o ensino, capacitação e atividades educacionais relacionadas aos direitos humanos e à luta contra o racismo, discriminação racial, xenofobia e intolerância correlata. (SILVA JR, 2002, p. 9).

As diversas ações desencadeadas pelos movimentos sociais, mesmo realizadas sem apoio institucional por parte do Programa Nacional do Livro Didático, surtiram efeitos favoráveis que sinalizavam avanços em relação à educação. Isso porque surgem, a partir delas, diversos textos legais com propostas de modificações nos livros por meio de Leis Orgânicas de diversos municípios brasileiros, como demonstra o quadro a seguir:

Quadro 5 - Propostas de modificações nos livros por meio de Leis Orgânicas de diversos municípios brasileiros

\begin{tabular}{|l|l|}
\hline \multicolumn{1}{|c|}{ Município } & \multicolumn{1}{c|}{ Referencial } \\
\hline Salvador & $\begin{array}{l}\text { Capítulo II. Art. 183 §6º́ É vedada a adoção de livro didático que dissemine } \\
\text { qualquer forma de discriminação ou preconceito. }\end{array}$ \\
\hline Goiânia & $\begin{array}{l}\text { Capítulo III. Seção I. Art. 236. O ensino será administrado com base nos } \\
\text { seguintes princípios (...) VIII - educação igualitária, eliminando estereótipos } \\
\text { sexíferos, racistas e sociais da sala de aula, livros e manuais destinados à } \\
\text { população infanto-juvenil. }\end{array}$ \\
\hline $\begin{array}{l}\text { São Luís do } \\
\text { Maranhão }\end{array}$ & $\begin{array}{l}\text { Capítulo III. Seção I. É proibida toda e qualquer manifestação preconceituosa } \\
\text { ou discriminatória de qualquer natureza nas escolas públicas municipais e nas } \\
\text { conveniadas com o município. }\end{array}$ \\
\hline $\begin{array}{l}\text { Belo } \\
\text { Horizonte }\end{array}$ & $\begin{array}{l}\text { Capítulo V. Art. 163. §4. É vedada a adoção de livro didático que determine } \\
\text { qualquer forma de discriminação ou preconceito. }\end{array}$ \\
\hline $\begin{array}{l}\text { Rio } \\
\text { janeiro }\end{array}$ & $\begin{array}{l}\text { Capítulo IV. Art. 321, VIII. Educação igualitária, eliminando estereótipos } \\
\text { sexistas, racistas e sociais das aulas, cursos, livros didáticos ou de leitura } \\
\text { complementar e manuais escolares. }\end{array}$ \\
\hline São Paulo & $\begin{array}{l}\text { Capítulo I. Art. 203, II. É dever do Município garantir: educação igualitária, } \\
\text { desenvolvendo o espírito crítico em relação a estereótipos sexuais, raciais e } \\
\text { sociais das aulas, cursos, livros didáticos, manuais escolares e literatura. }\end{array}$ \\
\hline
\end{tabular}

Fonte: (SILVA JR, 1998).

\subsection{O IMPACTO DA LEI 10.639/2003 NA PRODUÇÃO DE LIVROS DIDÁTICOS}

A lei 10.639, promulgada em 09 de janeiro de 2003, conforme exposto anteriormente, foi uma importante resposta a uma antiga demanda do Movimento Negro, tendo em vista promover uma educação que contribuísse para a valorização da cultura africana e afrobrasileira, modificando os currículos da Educação Básica.

Até o ano de 2003, os livros didáticos, de modo geral, abordavam os conhecimentos a serem transmitidos pela escola numa perspectiva eurocêntrica, normalmente ignorando 
conteúdos relacionados à temática africana ou dando ao negro uma representação marcada pelo preconceito e discriminação explícita ou implícita a partir de textos, imagens e exercícios em que estes ocupavam sempre posições sociais subalternas, a ideia de passividade diante da escravidão, ou representações pautadas em aspectos folclóricos e culturais que tratavam a África como algo "exótico" (JANZ, 2014, p. 3).

Nas resenhas de livros didáticos de História aprovados pelo Ministério da Educação integrantes do Guia de Livros Didáticos - PNLD 2005 das séries finais do Ensino Fundamental onde é oferecido aos professores uma síntese das coleções disponíveis para escolha e a avaliação de cada material por especialistas é possível observar a forma genérica e superficial como as informações acerca da temática africana são registradas, normalmente, a partir da temática Cidadania ou Construção da Cidadania e tratando de questões relacionadas ao eurocentrismo e ao preconceito e discriminação:

[...] ao se romper com uma organização eurocêntrica da História, estuda-se simultaneamente África, Ásia, Europa e América e se delineiam as experiências dos diferentes grupos sociais. (BRASIL, 2005 p. 50).

[...] explicita-se de maneira clara a opção pela denúncia de injustiças sociais e pela crítica constante a todas as formas de discriminação e racismo. O etnocentrismo é combatido e a diversidade das experiências humanas é respeitada [...] (BRASIL, 2005 p. 191).

É possível observar que a Lei 10.639/2003 provocou alterações significativas na forma como normalmente eram apresentados os livros nos Guias Didáticos. Estes passaram a exibir de forma específica e mais enfatizada informações sobre como as temáticas africanas e afrobrasileiras são apresentadas nas coleções, assim como indicar se esses materiais oferecem aos professores possibilidades de atividades mais aprofundadas sobre temas africanos.

A tabela disponível no anexo 2 deste trabalho apresenta uma síntese da forma como cada uma das coleções didáticas foram apresentados em 2014 no Guia do Livro Didático PNLD, em relação a Temática Africana. Essas sínteses foram elaboradas a partir de excertos da apresentação de cada obra disponível no Portal eletrônico do MEC - Ministério da Educação na página do PNLD - Programa Nacional do Livro Didático de 2014.

Além de promover mudanças que resultaram num cuidado específico ao tratamento das informações e possibilidades de trabalho propostas em cada coleção disponibilizada aos professores, é notável também o aumento quantitativo de livros paradidáticos de literatura infantil e infanto-juvenil que abordam de forma direta as culturas africanas.

No quadro disponível no anexo 3 foi apresentada uma síntese dos títulos produzidos por três importantes editoras a partir do ano de 2003 com temáticas relacionadas a cultura 
africana no segmento Didático, Paradidático e de Literatura Infantil e Literatura InfantoJuvenil. As informações sobre cada uma das obras elencadas foram produzidas a partir das informações contidas nas páginas eletrônicas das editoras consultadas. Foram elas as Editoras Ática, Moderna e Scipione.

É possível observar que foram produzidos e publicados 33 títulos a partir da promulgação da lei 10.639/2003. Esses títulos, ao tentarem atender aos critérios estipulados pelo MEC a partir do PNLD, de alguma forma também subsidiaram a construção de conhecimentos e práticas docentes acerca da temática. É preciso ressaltar que no banco de dados das editoras relacionadas na tabela apresentada neste estudo, não constam títulos referentes à África e a Cultura Africana com data anterior a 2003 nos segmentos Didático, Paradidático e de Literatura Infantil e Literatura Infanto - Juvenil o que sugere que a lei teve como efeito induzir a produção de livros sobre essas temáticas e, por consequência, contribuiu para difundir conhecimentos sobre a África e sua diversidade cultural, possibilitando a construção de imagens mais positivas sobre o negro e sua presença na sociedade brasileira. 


\section{UMA ANÁLISE DOS DISCURSOS CONTIDOS NOS PERIÓDICOS EDUCACIONAIS: O ENSINO DAS CULTURAS AFRICANAS E AFRO-BRASILEIRAS NAS REVISTAS NOVA ESCOLA E EDUCAÇÃO}

As revistas pedagógicas, de ampla divulgação, vendidas nas bancas de jornal e /ou distribuídas nas escolas constituem um tipo de periódico educacional amplamente consultado por professores brasileiros. Segundo Fernandes (2006), data de 1890 a produção brasileira mais antiga nesse segmento, a Revista Pedagógica, periódico publicado entre os anos de 1890 e 1896 pelo Pedagogium - Museu Escolar do Distrito Federal. De acordo com o autor, essa revista desempenhou um papel significativo na produção de saberes ligados à educação e, consequentemente, na progressiva constituição do campo disciplinar pedagógico, por meio da veiculação de um discurso educacional que, com o passar dos anos foi se tornando cada vez mais especializado.

Com valores acessíveis para a aquisição individual e convênios firmados entre Editoras e o Ministério da Educação - MEC que tornam ainda mais fáceis os acessos a esses materiais, as revistas pedagógicas auxiliam o desenvolvimento da prática docente viabilizando um acesso mais prático e simplificado às normativas legais. Com textos relativamente curtos e de fácil compreensão, essas revistas promovem, além de discussões acerca de temas educacionais que tratam de Leis e Diretrizes Educacionais, a circulação de planos de aulas e projetos desenvolvidos por professores em todo o Brasil que muitas vezes se tornam modelos prontos de atividades a serem aplicadas no cotidiano escolar.

Com o intuito de verificar o impacto da Lei 10.639/2003 no discurso educacional acerca do ensino das culturas africanas e afro brasileiras, examinaram-se como esse tema aparece em dois periódicos de grande circulação entre os docentes para análise que aqui se apresenta. São eles a revista Nova Escola e a revista Educação.

\subsection{SOBRE OS PROCEDIMENTOS ADOTADOS PARA ANÁLISE DOS ARTIGOS PUBLICADOS PELA REVISTA EDUCAÇÃO E NOVA ESCOLA}

O conjunto de publicações analisadas para a construção deste capítulo foi selecionado a partir dos bancos de dados das revistas Educação e Nova Escola disponíveis na internet e da consulta a exemplares disponíveis no acervo da Biblioteca da Faculdade de Educação da Universidade de São Paulo - FEUSP. Como recorte temporal foi realizada a seleção de publicações ocorridas entre os anos de 2003 e 2018, ou seja, publicações referentes ao ano em 
que a Lei 10.639/2003 foi promulgada tornando obrigatório o ensino das culturas africanas e afro brasileiras nas escolas de educação de todo o país e o mês de março de 2018.

A pesquisa no acervo digital dos periódicos na internet foi realizada a partir das palavras-chaves: "Cultura africana"; ensino das culturas africanas; África; Lei 10.639/2003; 11.645/2008. Foi possível, assim, obter um número significativo de textos que abordam a temática e objetivam veicular conhecimentos sobre os povos africanos, sobre sua influência cultural no Brasil tendo em vista subsidiar o trabalho docente no combate à discriminação racial.

É importante dizer que em virtude de recentes reformulações das páginas eletrônicas das revistas Educação e Nova Escola foram observadas falhas que geraram lacunas que impediram a consulta integral a todos os textos, sendo necessário, para garantir maior legitimidade a pesquisa, a consulta ao acervo físico dos dois periódicos disponíveis para consulta na Biblioteca da Faculdade de Educação da Universidade de São Paulo.

\subsection{SOBRE A REVISTA NOVA ESCOLA}

Trata-se um periódico especializado em temas educacionais criado em 1987 pelo jornalista e empresário Victor Civita, presidente do Grupo Editorial Abril. No ano de 2009 um convênio firmado entre a fundação Victor Civita e o Ministério da Educação (MEC) promoveu uma ampla distribuição da revista Nova Escola entre professores das redes oficiais de ensino de todo o Brasil. Seus conteúdos possuem uma perspectiva voltada à prática pedagógica que atingem principalmente professores que se dedicam ao ensino nas séries iniciais e finais do ensino fundamental, ou seja, do $1^{\circ}$ ao $9^{\circ}$ ano do ensino fundamental.

A revista Nova Escola é uma publicação mensal que, segundo Bueno (2007), alcança tiragens que chegam a atingir 700 mil exemplares mensais. Além disso, a revista também possui uma versão digital que disponibiliza parcialmente suas publicações por meio eletrônico em sua página na internet.

Dentre seus objetivos explícitos destaca-se:

[...] a expectativa de contribuir para a melhoria do ensino fundamental, divulgando informações que contribuam diretamente para a formação e o aperfeiçoamento profissional dos professores. (NOVA ESCOLA, n. 169, 2004, p.6).

Segundo Gentil, (2006), o periódico trata-se de um veículo institucional que une interesses públicos e privados e se volta à comunidade de professores da Educação Básica de 
todo o Brasil, contemplando os mais diversos assuntos em educação, sob as mais variadas formas: entrevistas, artigos, relatos de experiências dos professores, sugestões de atividades para sala de aula etc.

Desde o ano de 2015 a revista passou a ser produzido pela associação Nova Escola com o apoio de sua mantenedora, a Fundação Lemann que apoia e desenvolve projetos educacionais, realiza pesquisas para embasar políticas públicas no setor e oferece formação para profissionais da educação e para lideranças em diversas áreas.

Durante o levantamento de informações acerca deste objeto de pesquisa foi possível observar um crescente número de estudos, dentre eles teses de Doutorado e dissertações de Mestrado que desenvolveram análises desse periódico, dentre os quais se destaca a tese de Doutorado Revistas da área da educação e professores - interlocuções. Apresentada por Mônica Salles Gentil em 2006 na Universidade Estadual de Campinas, Faculdade de Educação e a dissertação de Mestrado intitulada Agora é para alfabetizar, sim ou não?: Análise dos discursos especializados sobre a idade certa para iniciar a alfabetização no contexto da ampliação do ensino fundamental para nove anos, apresentada por Andressa Caroline Francisco Leme em 2017 na Escola de Artes, Ciências e Humanidades da Universidade de São Paulo.

Com um valor de assinatura semestral em torno de 29 reais a revista possui um dos preços mais baixos dentre os periódicos no segmento educacional. O baixo custo pode ser explicado pelo apoio de inúmeras empresas privadas que, ao patrocinar parte dos custos, conseguem ampla divulgação de seus produtos.

\subsection{SOBRE A REVISTA EDUCAÇÃO}

Destinado aos profissionais que se dedicam ao ensino na Educação Básica, o periódico veicula artigos cujas temáticas relacionam-se ao campo educacional, tais como Políticas Públicas, Pedagogia, Literatura, Cultura e Economia entre outros. De grande circulação nacional, a revista criada em 1997 pelo jornalista e professor Marco Antonio Araujo é referência na área educacional e se propõe a promover uma reflexão crítica sobre práticas e políticas educacionais, dimensões da educação e o lugar que cabe à escola e ao ensino formal nesse processo. Com linguagem acessível, mas que adota termos mais técnicos, aborda eixos temáticos com pertinência para aqueles que vivem o cotidiano escolar, tais como: Gestão e infraestrutura educacional; Formação docente; Currículo Escolar; Leitura e letramento 
linguístico, matemático e pedagógico; Tendências e experiências nos sistemas educacionais mundiais; Sociedade, diversidade e escolarização e História e filosofia da educação.

A revista tem como um de seus compromissos "publicar matérias que possam levar ao questionamento daqueles que, apesar de toda dificuldade, continuam a formar gerações." (EDITORIAL, novembro/2004- p.11). Além de uma abordagem mais crítica dos temas educacionais possui um grande número de anúncios de produtos e serviços educacionais. Seu preço é superior ao da revista Nova Escola tanto para aquisição individual, cujo valor é de aproximadamente de 13 reais, quanto para a assinatura anual, custando o dobro do valor da assinatura da revista Nova Escola. Vale, no entanto, ressaltar que sua apresentação gráfica possui qualidade superior à da revista Nova Escola.

Quadro 6 -Distribuição dos artigos selecionados por ano*e por publicação

\begin{tabular}{|l|c|c|}
\hline Ano & Nova Escola & Educação \\
\hline 2003 & 4 & 2 \\
\hline 2004 & 5 & 2 \\
\hline 2005 & 8 & 4 \\
\hline 2006 & 5 & 2 \\
\hline 2007 & 4 & 3 \\
\hline 2008 & 1 & 2 \\
\hline 2009 & 2 & 2 \\
\hline 2010 & 4 & 1 \\
\hline 2011 & 6 & 19 \\
\hline 2012 & 3 & 1 \\
\hline 2013 & 2 & 3 \\
\hline 2014 & 3 & 2 \\
\hline 2015 & 7 & 7 \\
\hline 2016 & 5 & 6 \\
\hline 2017 & 28 & 2 \\
\hline 2018 & 3 & 1 \\
\hline Total de publicações & 90 & 59 \\
\hline
\end{tabular}

Fonte: (Eliane Maria Pereira, 2018).

*1Publicações ocorridas até março de 2018.

\subsection{SOBRE AS CARACTERÍSTICAS DAS PUBLICAÇÕES CATALOGADAS E} ANALISADAS

A pesquisa permitiu a construção de uma lista dos artigos sobre o tema "O ensino das culturas africanas e afro brasileiras a partir da promulgação da Lei 10639/2003” publicados 
pelos dois periódicos entre os anos de 2013 e 2018. Destes, 59 foram publicados pela revista Educação e 90 pela revista Nova Escola.

Notou-se a partir da apreciação do conjunto de artigos catalogado que um número significativo de textos consistiam na indicação de leituras e filmes sobre a temática africana, planos de aulas, projetos executados com êxito nas redes públicas e privadas de ensino, indicação de cursos de formação sobre a temática africana, conhecimentos gerais sobre o continente africano e suas especificidades, textos que abordam práticas de formação dirigidas aos docentes, além de enquetes contendo a opinião de profissionais de ensino e intelectuais acerca da obrigatoriedade do ensino da temática a partir da lei 10.639/2003 e, posteriormente, lei 11.645/2008.

Quadro 7 - Principais temas abordados

\begin{tabular}{|l|c|c|}
\hline Legislação e contextualização social: & Nova Escola & Educação \\
\hline Condição social do negro no Brasil & 2 & 5 \\
\hline Estudos relacionados à história da educação do negro & 7 & 11 \\
\hline Lei 10.639/2003 e 11.645/2008 & \multicolumn{2}{|c|}{8} \\
\hline Conhecimentos gerais sobre o continente africano: & \multicolumn{2}{|c|}{13} \\
\hline Questões sociais africanas: cultura, educação e política. & \multicolumn{2}{|c|}{13} \\
\hline Orientação para a prática: & 34 & 0 \\
\hline Indicação de cursos de formação sobre a temática africana & 6 & 7 \\
\hline Planos de aulas & 14 & 2 \\
\hline Práticas de formação dirigidas aos docentes & & \\
\hline Projetos executados nas redes públicas e privadas de ensino & & \\
\hline
\end{tabular}

Fonte: (Eliane Maria Pereira, 2018).

As revistas Nova Escola e Educação utilizadas para a construção da presente análise foram publicadas mensalmente entre os anos de 2003 e 2018, ou seja, durante todo o período desde a promulgação da Lei 10.639 de 09 de janeiro de 2003, que foi assinada pelo então Presidente da República Luiz Inácio Lula da Silva, tornando obrigatório o ensino das culturas africanas e afro-brasileiras nos currículos da Educação básica de todo o país.

Os artigos veiculados pelas duas revistas são, em sua maioria, assinados pelos profissionais que compõem as equipes jornalísticas das editoras e se responsabilizam por 
todas as etapas que envolvem o processo editorial. Existem artigos, no entanto, cuja autoria individual não é divulgada, recebendo a assinatura de autoria da própria revista, ou seja, sem a identificação de um autor em específico. Esses casos ocorrem tanto nas revistas impressas quanto nas publicações online.

Em linhas gerais, os autores responsáveis pelas publicações são jornalistas especializados na área educacional. Esses profissionais assinam textos dedicados aos mais diversos assuntos, dentre eles, os relacionados ao ensino das culturas africanas e afro brasileiras.

Na revista Nova Escola, grande parte dos artigos analisados são de autoria da jornalista e escritora Paola Gentili, de Roberta Bencini, jornalista e editora e de Débora Menezes, jornalista e mestre em educação. Além delas, foram encontrados artigos assinados por Ana Rachel Ferreira, Cristiane Maragon, Camila Camilo, Daniele Pechi, Elena Meireles, Caroline Monteiro, Larissa Teixera, Leonardo Sá e Paula Peres. Todos esses profissionais são graduados em jornalismo e possuem especialização em Educação. Os textos são escritos em colaboração entre os profissionais e contam com assessoria de intelectuais dedicados ao estudo de questões mais específicas e complexas de temas educacionais e também de professores e outros profissionais que atuem em escolas públicas e privadas. Como exemplo é possível citar o artigo "Um jogo de tabuleiro que veio da África" publicado na revista Nova Escola, número 64, de novembro de 2005, o qual, para apresentar as possibilidades do uso didático escolar do jogo africano "Kalch", contou com a consultoria da coordenadora pedagógica de uma escola de São Paulo, Carolina Villas Boas, que tratou das possibilidades de desenvolvimento das habilidades de atenção e antecipação em crianças a partir do uso desse jogo africano ainda pouco conhecido entre os educadores brasileiros.

São comuns nos artigos da revista Nova Escola a referência a visitas a escolas públicas e privadas apresentando-se assim uma narrativa que pressupõe uma proximidade maior com a realidade dos professores e profissionais que se dedicam ao ensino.

Os discursos contidos nos artigos da revista Nova Escola disseminam ideais que percorrem os textos legais, o pensamento intelectual nacional e internacional e o discurso práticos dos professores. Todas as ideias são simplificadas e anexadas numa espécie de processo de compilação feito a partir da escrita jornalística que veicula essas informações fazendo-as chegar ao seu público alvo principal, os professores.

Intelectuais como Eliane Cavalheiro, Kabenguele Munanga, Nilma Lino dos Santos e Petronilha Beatriz Gonçalves e Silva, dentre outros, são citados nos artigos de forma 
recorrente para embasar afirmações relacionadas a temas mais polêmicos, como as questões relacionadas às políticas de cotas raciais, preconceito e racismo.

Tratando da questão do ensino das culturas africanas e afro-brasileiras com um teor um pouco mais amplo e denso e com menos questões relacionadas às práticas de ensino, a autoria dos artigos da revista Educação é assinada por profissionais graduados em jornalismo com especialização em Cultura e Educação. Dentre esses profissionais é possível citar Rubens

Barros, Luciana Alvarez e Fernanda Castro. Também foram encontradas publicações cuja autoria não é assinada individualmente, mas sim, como autoria editorial, ou seja, em nome do periódico.

Os textos analisados também embasam suas afirmações relacionadas a temas mais polêmicos em citações de intelectuais que se dedicam ao estudo da temática africana, assim como é comum nos textos dos artigos da revista Nova Escola.

\subsection{LEGISLAÇÃO E CONTEXTUALIZAÇÃO SOCIAL}

De forma recorrente, os dois periódicos abordam a obrigatoriedade do ensino das culturas africanas a partir do texto legal, ou seja, citam a Lei 10.639/2003 para anunciar a obrigatoriedade do ensino dessa temática, mas a partir de então, nota-se uma diferenciação entre os dois. Na revista Educação observa-se a ampliação desse embasamento quando é abordada a atuação dos movimentos sociais, assim como a contextualização histórica do processo de legalização da valorização e do ensino escolar das culturas africanas. Quanto à revista Nova Escola, em relação à contextualização histórica, essa se dá de forma mais superficial. Questões relacionadas ao combate à discriminação, cotas raciais e preconceito racial normalmente são abordadas pela revista Nova Escola numa perspectiva legal, apresentando-se apenas uma breve explanação acerca das condições históricas e sociais que envolvem o tema.

Com uma abordagem mais crítica e reflexiva da realidade que pauta o contexto educacional brasileiro, a revista Educação aborda a lei 10.639/2003 apresentando e discutindo dados sociais e econômicos produzidos e divulgados por institutos como o IPEA e IBGE. As presenças de dados estatísticos nos artigos analisados permitem a construção de um entendimento mais analítico e reflexivo do contexto que envolve a obrigatoriedade da temática. São observados também discussões acerca do Mito da Democracia Racial e sobre o racismo no cotidiano escolar, como ocorreu, por exemplo, no artigo "Década encoberta", de autoria da jornalista Fernanda Castro, publicado em 09 de dezembro de 2003. O texto 
problematiza a implementação da Lei 10.639/2003 após quase dez anos de sua promulgação relacionando as principais dificuldades citadas por professores, especialistas e sistemas de ensino para a sua efetiva implementação a falta de oportunidades de formação para os professores, questões religiosas e ao racismo.

[...] Para mudar essa realidade, foi aprovada, em 2003, a Lei 10.639 que altera a Lei das Diretrizes Básicas da Educação (LDB) inserindo a história e cultura afrobrasileira e africana como conteúdos obrigatórios. Seis anos depois, em 2008, a Lei 11.645 inclui também a história e cultura dos povos indígenas brasileiros. Para entusiastas, as leis têm efeito multiplicador e favorecem mudanças na formação dos professores e nos materiais didáticos. (EDUCAÇÃO, 2016).

É notório o impacto produzido pela Legislação nos dois periódicos analisados, num primeiro momento pela maior incidência de textos que tratam de temas ligados a temática africana e, mais aprofundadamente, observa-se, principalmente na revista Educação, artigos que problematizam o processo de implementação superficial da lei, a partir de uma perspectiva histórica e contextualização das dificuldades apresentadas pelos docentes.

A proposta do MEC é incluir no currículo temáticas que façam os alunos refletir sobre a democracia racial e a formação cultural brasileira. Só assim será possível romper com teorias racistas e diminuir o preconceito, afirma Juliano Custódio Sobrinho, professor de História da Universidade Nove de Julho, em São Paulo. Os educadores têm um papel fundamental nesse processo, o de mostrar aos alunos que todas as raças presentes no Brasil têm e tiveram importâncias iguais na formação da cultura brasileira, diz. (PECHI, 2011).

Em relação à revista Nova Escola o volume de publicações demonstra o impacto da Lei e um esforço notório para, a partir da prática, viabilizar a efetiva implementação da Lei 10.639/2003. Esse esforço se materializa através dos muitos planos de aulas e sugestões de atividades publicadas pela revista. Conforme é possível observar no quadro construído a partir das publicações catalogadas, os planos de aulas representam a maioria das publicações acerca da temática africana. Foram 34 publicações o que representa quase metade de todas as publicações realizadas pela revista Nova Escola entre os anos de 2013 e 2018.

\subsection{CONHECIMENTOS GERAIS SOBRE O CONTINENTE AFRICANO}

A revista Educação aborda com maior frequência temas relacionados ao continente africano. Esses artigos tratam de problemas sociais relacionados à educação, economia e religião repercutidos pela mídia e que de alguma forma contextualizam o continente africano. Esses textos permitem a construção de conhecimentos sobre o continente a partir de uma realidade construída e veiculada pela mídia. 
É possível perceber, a partir da proposta editorial dessa revista que aspectos culturais são de fato privilegiados, tornando, de modo geral, suas publicações mais densas e completas

Historiador britânico expõe vísceras da cultura extrativista que pontua continente africano: Se a história do Brasil é marcada pela cultura extrativista que tão pouco nos legou em termos de condições sociais mais igualitárias para toda a população, questão que nos aflige até os dias de hoje, o que dizer do continente africano, berço de muitos dos que hoje dão cara ao Brasil?[...] (BARROS, 2017).

Faz-se necessário ressaltar que a falta de conhecimentos sobre o continente africano que é formado por 56 países e uma gigantesca diversidade étnica e cultural é um dos problemas apontados por especialistas para dificuldade encontrada por professores em tratar das temáticas africanas em sala de aula.

A revista Educação possui uma quantidade superior de textos que tratam de aspectos relacionadas à cultura africana. Os problemas sociais, políticos e educacionais africanos são abordados e discutidos na revista com maior frequência do que se observa na revista Nova Escola. Esta última, ao tratar do Continente africano se detêm, quase na totalidade dos artigos analisados, em questões educacionais e em sugestões de atividades inspiradas em brincadeiras e jogos africanos com potencial de uso didático em escolas brasileiras.

\subsection{ORIENTAÇÕES PARA A PRÁTICA}

A formação de professores para o ensino das culturas africanas e afro-brasileiras é tratada pelas revistas Educação e Nova Escola como um ponto fundamental para o sucesso da implementação da Lei 10.639/2003 e um de seus pontos mais críticos. Nesse sentido essa questão é tema central dos artigos publicados por ambas, mas discutida de forma distinta. A revista Educação apresenta o problema discutindo-o, mas não apresenta soluções práticas que vão além da obrigação do Ministério da Educação possibilitar aos professores e a outros profissionais de ensino uma formação mais adequada e contínua sobre o tema. Em algumas publicações é possível notar também a responsabilização do professor por sua formação, mas essa responsabilização é sempre seguida pela reiterada concepção de que o Governo e seus sistemas de ensino precisam proporcionar essa oferta de modo regular e contínuo.

Em síntese, a revista Nova Escola possui uma abordagem voltada à prática docente com artigos que se propõem a ensinar os professores a abordar o ensino das culturas africanas e afro-brasileiras de acordo com as determinações legais. São privilegiados neste periódico os planos de aulas e projetos em consonância com a legislação. Eles são apresentados aos professores com a descrição de todas as etapas de desenvolvimento numa espécie de modelo 
de movimentos sociais, como o Movimento Negro e suas inúmeras vertentes espalhadas pelo país que reivindicavam, dentre outras demandas, o acesso à educação e a um Currículo Escolar que contemplasse a História e as Culturas Africanas. Nota-se que nos discursos produzidos ao longo da história pelo Movimento Social Negro o acesso à educação formal é concebido como condição necessária para a integração social do Negro, ascensão política e econômica, além de mecanismo fundamental para o enfrentamento e superação do racismo.

A Lei 10.639/2003 chegou ao Congresso Nacional na forma de Projeto de Lei 259 como resultado de um processo histórico de reivindicações sociais que, dentre outras demandas, objetivava promover reparação social a população negra, por meio da educação formal, pelas sequelas de mais de 300 anos de escravidão vivenciadas no Brasil que germinaram na população brasileira desigualdades e injustiças sociais que atingiam principalmente as populações negras. Ao vislumbrar criar uma legislação que tornasse obrigatório o ensino das culturas africanas objetivou-se valorizar a riqueza e a diversidade cultural africana incorporada pela sociedade brasileira, mas que não possuía um espaço dentro dos currículos de escolarização formal. O projeto colocou em discussão a europeização do currículo oficial brasileiro e a invisibilidade das matrizes africanas, quase sempre não discutidas ou estereotipadas pelas práticas escolares. O projeto de lei tramitou durante anos no Congresso Nacional, sendo assinada em 09 de janeiro de 2003 pelo Presidente Luiz Inácio Lula da Silva, num período de grande efervescência popular, que se deu durante a chegada do PT - partido dos trabalhadores a Presidência do Brasil. A aprovação da Lei 10.639/2003 foi seguida por um longo processo de regulamentações que pudessem viabilizar sua aplicação. Foram elaborados textos oficiais que discutiam e orientavam sua aplicação e que tentavam suprir a falta de conhecimentos acerca das culturas africanas que tanto dificultava o trabalho docente.

Em sequência foi apresentada uma análise dos impactos da Lei 10.639/2003 em relação ao tratamento dado à questão racial em livros didáticos indicados pelo Programa Nacional do Livro Didático - PNLD. Por fim, analisou-se o impacto da Legislação em revistas especializadas como Nova Escola e Educação publicadas entre os anos de 2003 e 2018. Procurou-se, a partir da perspectiva teórica aberta pelos Estudos Culturais acerca da análise das formações discursivas, compreender os impactos gerados pela Lei 10.639/2003 nos discursos pedagógicos contidos em materiais especializados de grande circulação como são os periódicos educacionais. O que se procurou fazer, portanto, foi uma caracterização dos discursos sobre o ensino das culturas africanas considerando o aspecto legal, orientador e formativo a partir da leitura dos artigos selecionados. 
de como se trabalhar de forma mais acertada as questões relacionadas ao ensino das culturas africanas e afro-brasileiras cumprindo o que determina a legislação.

Como um espaço de reflexão e construção de conhecimento, a escola não pode ficar de fora. Por isso, NOVA ESCOLA selecionou seis atividades que abordaram temas como racismo, identidade, história e cultura. Inspire-se pelos bons exemplos e convide a turma a refletir. (TEXEIRA, 2017)

É notável também a responsabilização dos professores em fazer a implementação da Lei 10.639/2003 ocorrer de fato nas escolas uma vez em que em diversos momentos a importância de sua atuação é reforçada nos diversos artigos analisados.

Nas duas publicações, o professor é apresentado como sujeito responsável por sua formação, sendo reforçada sua responsabilidade em construir conhecimentos e pôr em prática as determinações legais.

[...] "Cabe aos educadores abrir espaço para as demandas, vencer o preconceito institucionalizado e preencher lacunas na sua própria formação afirma”. (GATAMORTA, 2016).

A revista Nova Escola, no entanto, fornece inúmeras sugestões práticas de atividades que podem ser desenvolvidas pelos professores. São formas distintas de tratar o problema claramente observáveis entre os dois periódicos. Elas se assemelham ao tratar da importância da formação dos professores sobre a temática, mas se distanciam à medida que o assunto se aprofunda e caminha para a apresentação de possíveis soluções práticas.

Outra questão tratada de forma semelhante pelos dois periódicos, é a formação de professores para o ensino das culturas africana e afro-brasileiras. As duas publicações divulgam regularmente cursos ofertados para professores e ao público em geral sobre questões africanas e a Lei 10.639/2003.

\footnotetext{
“Curso sobre história e cultura africana tem inscrições abertas na USP. Programa é voltado a professores das redes pública e particular; matrículas vão até o dia 13 de março". (EDUCAÇÃO, 2017).

"Seis leituras essenciais para lidar com o racismo na Educação Infantil". (FERREIRA, 2016)
}

Elas também apresentam em seções específicas de divulgação de livros e indicação de Leituras sobre essas temáticas. São, portanto, divulgados regularmente filmes, livros e cursos presenciais e à distância ofertados pela iniciativa pública e privada no país cujo objetivo é promover conhecimentos acerca da cultura africana e de práticas didáticas que possibilitem o combate ao racismo e à discriminação racial. 


\subsection{SOBRE AS IMAGENS QUE ILUSTRAM AS PUBLICAÇÕES}

Ao abordar o continente africano em seus conteúdos, a revista Nova Escola o faz sempre pelo viés educacional abordando temas relacionados a jogos e musicalidade. São conteúdos apresentados de forma didática que ensinam ao professor como trabalhar em salas de aulas brasileiras as práticas culturais e educacionais africanas. Os títulos são objetivos e são seguidos por pequenas notas que tornam a apresentação inicial ainda mais clara e objetiva. No Artigo intitulado "África de todos nós", escrito por Paola Gentili, e publicado em 01 de novembro de 2005, é possível exemplificar como são apresentados esses artigos: "Desde 2003, a cultura africana faz parte do currículo. Descubra com seus alunos a riqueza das ciências, das tecnologias e da história dos povos desse continente".

Figura 1 - Exemplo de imagem utilizada pela revista Nova Escola para representar o continente africano

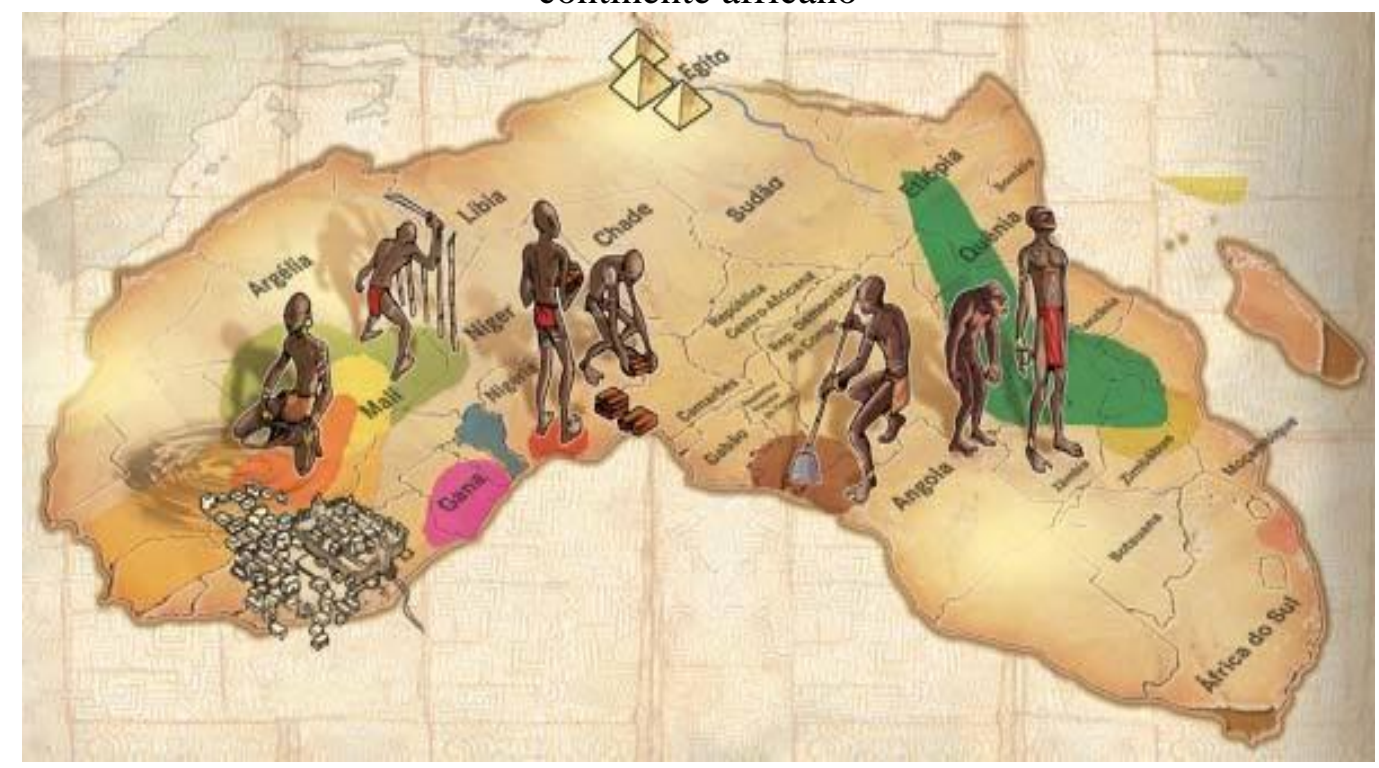

Fonte: Gentili (2005)

Uma outra característica dos artigos que tratam do continente africano e de suas especificidades é que eles possuem normalmente uma única página e poucas vezes apresentam cenas reais do Continente, como fotos, por exemplo. Normalmente são inseridas figuras coloridas, ou, quando são utilizadas imagens reais, retratam rituais festivos ou crianças brincando. Nota-se, a exemplo da imagem apresentada, um caráter estereotipado e preconceituoso da representação da África, que, num material contemporâneo como em que ela se faz presente, acaba por produzir um efeito contrário em relação ao objetivo da lei. 
Ao abordar a educação argeliana a partir de uma pesquisa acerca do nível de satisfação das crianças desse país em relação à escola, a revista Educação, em 01 de junho de 2015, como normalmente faz, utilizou imagens reais de crianças indo à escola.

Figura 2 - Exemplo de imagem utilizada para representar crianças africanas

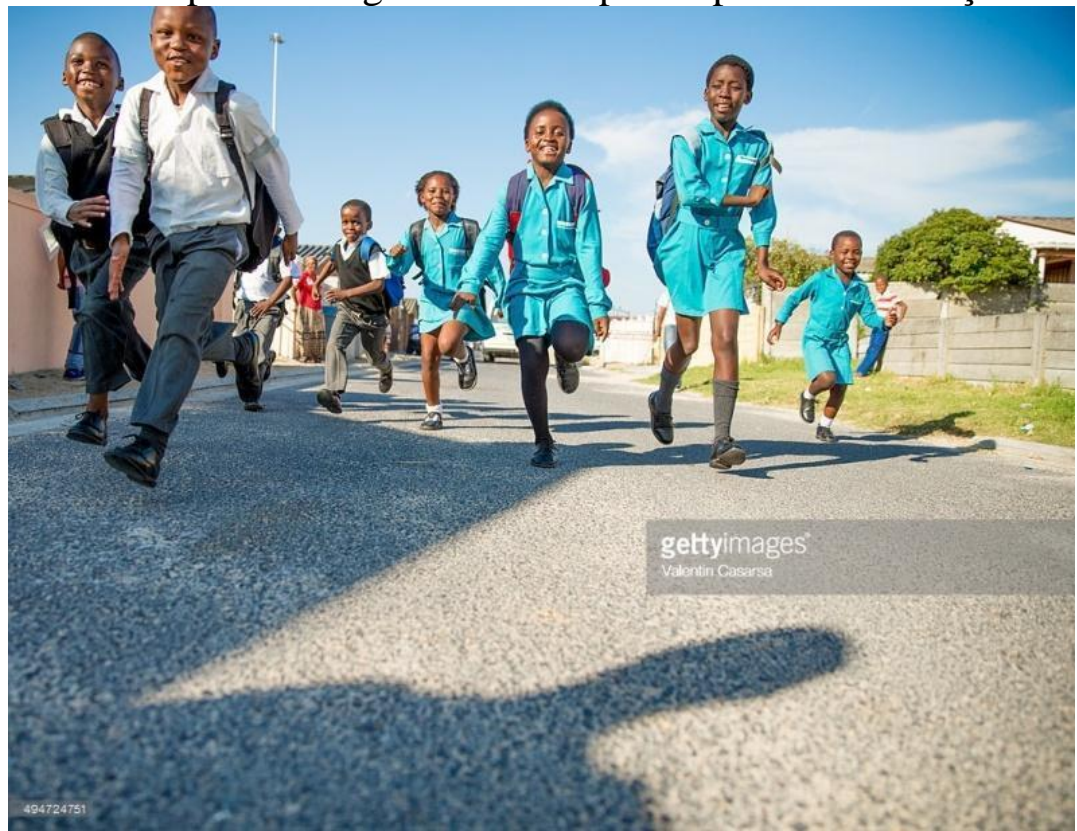

Fonte: Educação (2015)

A revista Educação privilegia em suas publicações o uso de imagens reais e coloca as pessoas negras em primeiro plano, normalmente em situações cotidianas e não apenas escolar, como ocorre na revista Nova Escola.

\subsection{COMO OS DISCURSOS ANALISADOS SE DIRIGEM AOS PROFESSORES?}

Os textos da revista Nova Escola apresentam um caráter instrutivo com modelos de aulas prontas e sugestões de atividades que visam facilitar o trabalho docente. Esses planos de ensino e sugestões de atividades compõe a maior parte das publicações. Não foram encontrados, por exemplo, artigos que submetam a Lei 10.639/2003 a uma análise crítica, mas apenas textos em concordância com o teor da Lei. A única exceção trata-se de uma publicação da revista Nova Escola ocorrida em maio de 2003 quando a partir de uma enquete, três profissionais de ensino foram convidados a opinar a respeito da criação de leis ser, de fato, a maneira mais correta de levar a questão racial para as salas de aula. Dos três entrevistados, 
apenas um posicionou-se a favor da obrigatoriedade do ensino da Cultura Africana por meio de um dispositivo legal. : “A Lei só vem somar ao que é sugerido pelas Diretrizes Curriculares Nacionais. No Brasil, temos que chover no Molhado" [...]. (FERES, 2003).

A opinião de Maria José Vieira Féres, que era então Secretária de Educação Fundamental do Ministério da Educação - MEC divergiu dos outros dois entrevistados, dentre eles o Pesquisador e Coordenador de Pós Graduação em Educação da Pontifícia Universidade Católica de São Paulo - PUC/SP, Antônio Chizzotti, que declarou: "A inclusão formal atrapalha a abordagem do assunto dentro das escolas: Um tema tão importante não deve ser imposto" [...] (CHIZZOTTI, 2003)

Entre os anos de 2003 e 2018, não ocorreram mais publicações que questionassem a forma ou o conteúdo da legislação, prevalecendo a concepção de que a Lei 10.639/2003 voltava-se para a correção de uma desigualdade histórica que recaiu sobre os negros brasileiros. Essa concordância em relação ao texto legal e a ausência de questionamentos diretos são adotadas pelos dois periódicos. No artigo "A história da África em sala", de Daniele Pechi, publicado em 01 de outubro de 2011 na revista Nova Escola nota-se a seguinte expressão "Duas leis federais determinam o ensino de história e cultura afro-brasileira e indígena. Veja como trabalhar esses conteúdos em aula”. (PECHI, 2017)

A recorrente argumentação embasada na conotação de obrigatoriedade traz muitas vezes um discurso de ordem, cujo não atendimento é compreendido como omissão e resistência.

\footnotetext{
"Diante da omissão das escolas em tomar à frente das iniciativas, o professor de história, filosofia e sociologia Eduardo Fera ressalta o papel do docente como protagonista desse processo [...]" (EDUCAÇÃO, 2016).
}

Além de citar a obrigatoriedade legal e responsabilizar a escola e os docentes pela efetiva implementação da legislação, os textos costumam apresentar as justificativas mais recorrentes para o não atendimento a Lei presentes nos discursos docentes e sistemas de ensino.

[...] Para ajudar os professores a selecionar alguns aspectos que podem ser trabalhados nas diferentes etapas de ensino no decorrer de todo o ano, o MEC elaborou alguns materiais de apoio que estão disponíveis para consulta no site oficial do Ministério, assim como as Orientações e Ações para a Educação das Relações Étnico-Raciais. Abaixo, veja algumas sugestões de como e quando abordar alguns dos conteúdos relacionados à cultura afro-brasileira em diferentes etapas de ensino[...] (PECHI, 2011) 
Essa construção narrativa típica adianta e esgota as possibilidades de argumentação na própria leitura. Principalmente por ser seguida de sugestões de leitura e atividades práticas, como ocorre de forma recorrente nas publicações da revista Nova Escola. 


\section{CONCLUSÃO}

O objetivo deste trabalho foi analisar a Lei 10.639/2003 que instituiu a obrigatoriedade do ensino das culturas africanas e afro brasileiras nos currículos de Educação Básica assim como dos discursos veiculados a partir de sua promulgação, ocorrida em 09 de janeiro de 2003. Para isso, inicialmente buscou-se caracterizar as condições históricas vividas no Brasil associadas à composição multirracial da população brasileira, o persistente racismo que caracteriza a sociedade e as resistências que tomaram forma nos movimentos sociais. A motivação para a pesquisa se deu em razão das dificuldades vivenciadas enquanto professora da rede municipal de ensino de São Paulo em encontrar subsídios didáticos e metodológicos que pudessem viabilizar o atendimento a determinação legal contida na Lei 10.639/2003 e dos problemas fomentados pelo Mito da Democracia Racial que ainda influencia as relações dentro e fora do espaço escolar dificultando, por exemplo, a discussão entre a comunidade escolar sobre as possibilidades de abordagem do tema em sala de aula. Sem formação inicial e nem continuada, os discursos que se faziam circular através dos periódicos educacionais foram por inúmeras vezes o único material orientador e formativo a que os docentes tiveram acesso durante os primeiros anos de vigência da Lei 10.639/2003. Isso porque, o processo de adequação dos materiais de apoio ao trabalho docente como, por exemplo, os livros didáticos distribuídos em escolas públicas através do Programa Nacional do Livro Didático, também se deu de forma lenta e gradual e, as revistas pedagógicas, em razão de convênios com o governo federal que facilitou cada vez mais sua distribuição nas escolas, de maneira bastante prática e objetiva, se fez presente nas salas de professores e formações pedagógicas tratando de questões importantes sobre educação e práticas pedagógicas, dentre elas, as relacionadas à questão racial no Brasil.

A primeira etapa do trabalho de pesquisa resultou na construção de uma perspectiva sobre o contexto sócio histórico dos debates que deram origem ao projeto de lei e de sua trajetória no Congresso Nacional até sua aprovação e promulgação. Foram abordados os principais discursos científicos que circularam na Europa e no Brasil entre os séculos XVIII e XIX buscando explicar numa perspectiva racial as desigualdades sociais existentes entre brancos e negros. Esses discursos fomentaram a construção de argumentos debatidos por intelectuais brasileiros que objetivavam explicar nossa nação e suas especificidades sociais, dentre elas, a miscigenação e desigualdade social que caracterizava a população brasileira. Com uma desigualdade econômica e social histórica entre a população branca e negra, a luta por melhores condições de vida para a população negra no Brasil ganhou força e voz através 
Verificou-se a partir de um levantamento bibliográfico realizado com o objetivo de identificar as produções acadêmicas contemporâneas sobre o tema que, além do aumento quantitativo de artigos científicos, livros didáticos e artigos de revistas abordando o tema após a promulgação da Lei, ou seja, a partir do ano de 2003, uma preocupação em fornecer subsídios didáticos e metodológicos aos professores em sala de aula também surgiu, sempre embasando os argumentos discursivos na obrigatoriedade legal e nos relatos de professores que enfrentam o desafio de colocar em prática a modificação que essa legislação promoveu nos currículos escolares de todo o país. Os periódicos especializados analisados assumem, por vezes, um caráter formativo dando aos docentes noções básicas de como atender a legislação a partir de discursos voltados ao fornecimento de informações acerca do continente africano e modelos prontos de atividades, sugestões de assuntos relacionados à temática e a exemplos de aulas consideradas bem-sucedidas pelos autores e responsáveis editoriais desses periódicos.

Os artigos científicos analisados também apresentam em seus discursos a ideia de legalidade, ou seja, repetem reiteradamente o fator da obrigatoriedade e do dever de cumprimento da legislação em vigor, justificando-a normalmente a partir da ideia de justiça social ou reparação aos danos sociais e econômicos a que estariam submetidos ainda os negros em nosso país em virtude dos 300 anos de escravidão a que estiveram submetidos. Foi observado um crescente número de publicações que discutem a temática africana e suas possibilidades reais de aplicação numa perspectiva crítica que problematiza a oferta de formação aos docentes tanto em questões quantitativas quanto qualitativas. Essas publicações não se resumem a artigos científicos, mas ganham forma de dissertações de mestrado e teses de doutorados que aprofundam ainda mais as discussões ampliando a problemática para o âmbito do ensino superior onde se encontram possibilidades de discussão fundamentais para se tratar mais efetivamente a questão. O levantamento bibliográfico demonstrou, portanto, uma preocupação com aspectos teóricos e práticos sobre a legislação considerando de forma mais ampla as possibilidades e dificuldades encontradas pelos professores, pelas comunidades escolares e sistemas de ensino em atender a legislação no tocante às modificações dos currículos oficiais e alcance dos objetivos estipulados pela legislação.

Em relação aos livros didáticos, de forma bastante objetiva, observou-se modificações tanto em aspectos quantitativos quanto qualitativos. Isso porque a forma como a questão racial era abordada nesses materiais não demonstrava ser objeto de preocupação para o Governo Brasileiro, pelo menos até o fim da década de 1980 quando essa preocupação figurava nos documentos oficiais de forma bastante superficial. Com a promulgação da Lei 10.639/2003 observou-se que assuntos relacionados à escravidão foram aos poucos 
substituídos por abordagens relacionadas, por exemplo, à aspectos culturais do continente africano, como o desenvolvimento econômico e social desse Continente e suas especificidades culturais, além da forte influência e presença dessas culturas no Brasil. Modificou-se, portanto, um paradigma escolar que enquadrava o negro brasileiro quase sempre a condição de escravo, passando a apresentá-lo como sujeito histórico e social. Além disso, a temática africana ganhou espaço nos textos de apresentação dos livros didáticos indicados pelo Programa Nacional do Livro Didático tornando-se um dos itens de análise destacados nos resumos de cada obra e de avaliação realizados pelo Ministério da Educação.

Ao concluir este trabalho, espera-se ter oferecido subsídios para a compreensão das condições históricas e sociais que fomentaram em nossa sociedade a reivindicação de uma legislação que pudesse criar condições para a superação do racismo. Buscou-se apresentar a lei 10.639 /2003 e os discursos a partir dela produzidos atentando para a forma como estes assumem um caráter de verdade e são dirigidos aos professores. Essa problemática demonstra uma concepção de educação e de formação docente que historicamente trata a escola e os professores como reprodutores de projetos políticos e sociais sob a premissa de um discurso que trata a escola como principal espaço de transformação social e, ao professor, como um agente fundamental para essa transformação. Esses discursos ganham forma na produção de legislação e materiais de formação e orientação que ensinam a escola e a seus agentes a como colocar em prática as determinações legais. Esse processo de "ensinar a fazer" por vezes cria uma grande quantidade de informações e orientações a serem seguidas, mas esvaziadas de sentido e de condições reais de efetivação. Uma superficial verdade reproduzida na forma de determinações legais, mas que se configura como prática esporádica que não se incorpora realmente a cultura escolar. Sendo assim, o que se percebe é uma concordância com um discurso que se tornou oficial, mas que não encontrou ainda as bases necessárias para sua incorporação à cultura escolar. Essa incorporação vem aos poucos acontecendo, mas num processo ainda lento e impulsionado muito mais pela força da legislação do que por um processo de conscientização político e social. Quanto a isso, acredita-se ser fundamental ampliar oportunidades de formação e discussão a respeito de nossas matrizes sociais e as origens das desigualdades sociais que afetam a população brasileira. 


\section{REFERÊNCIAS ${ }^{40}$}

ACADEMIA BRASILEIRA DE LETRAS [website]. Acadêmicos. Afonso Arino de Melo Franco. Disponível em: < http://www.academia.org.br/academicos/afonso-arinos-de-melofranco/biografia $>$ Acesso em: 25 jun. 2018.

ALLGAYER, H. HILLER, R.F. Uma análise acerca da ética evolucionista tradicional (Darwinismo Social): Críticas sobre a fundamentação evolutiva. Revista Problemata, v. 6 p. 178-193, 2015. Disponível em:

<http://www.periodicos.ufpb.br/ojs/index.php/problemata/article/view/22601> Acesso em: 15 dez. 2017

ALMEIDA, M.A.B.; SANCHEZ, L. P. Implementação da Lei 10.639/2003 - competências, habilidades e pesquisas para a transformação social. Pro-posiçoes [online], v.28, n.1, p.55-80, 2017. Disponível em: $<$ https://www.fe.unicamp.br/publicacoes/noticias/lancamento-darevista-pro-posicoes-vol28-n1-82-janabr-2017> Acesso em: 17 nov. 2017.

ALVES, E. F. Por que a Medicina ignora a teoria da evolução? Cracionismo. Maringá: Editorial NUMARSCB, 2015, p.171-182. Disponível em: < http://www.criacionismo.com.br/2015/08/por-que-medicina-ignora-teoria-da.html > Acesso em 18 out. 2017.

AMÉRICO, M. C; Luiz, V. Formação de professores em uma perspectiva multirracial: a Lei n. 10.639 e as contribuições para a consolidação de uma autoimagem negra positiva. Revista identidade! V. 15, n. 2, jul.-dez. 2010, p. 85-98. Disponível em:

<http://periodicos.est.edu.br/index.php/identidade/article/view/31/149>. Acesso em: fev. 2016.

ANSELMO, Eliane Regina Martins. Das práticas políticas e jurídicas na formação de professores para educação étnico-racial. 2015. 194 f. Tese (Doutorado em Educação) Faculdade de Educação, Universidade Federal do Rio Grande do Sul, Porto Alegre, 2015.

ATICA/SCIPIONE [website]. Catálogo didático e paradidático. Disponível em: < http://www.aticascipione.com.br/> Acesso em: 25 out. 2017.

AZEREDO, S. A questão racial na pesquisa. In: AZEREDO, S., STOLCKE, V. (coords.) Direitos reprodutivos. São Paulo: FCC [PRODIR], 1991. p.125-30.

BAKKE, Rachel Rua Baptista. Na escola com os orixás: o ensino das religiões afrobrasileiras na aplicação da Lei 10.639. 2011. 222f. Tese (Doutorado em Antropologia Social). Faculdade de Filosofia Letras e Ciências Humanas. Universidade de São Paulo, São Paulo, 2011.

${ }^{40}$ De acordo com a Associação Brasileira de Normas Técnicas (ANBT NBR 6023). 
BARROS, R. Historiador britânico expõe vísceras da cultura extrativista que pontua continente africano. Revista Educação, edição 244, ago. 2017. Disponível em: < http: //revistaeducacao.com.br/historiador-britanico-expoe-visceras-da-cultura-extrativista-quepontua-continente-africano> Acesso em: 12 jan. 2018.

BEISIEGEL, C. Cultura e democracia dos movimentos sociais na articulação entre o Estado e a sociedade brasileira nos séculos XIX e XX. Revista Educação e Sociedade [online]. 2006, vol.27, n.97, pp.1137-1157. Disponível em:

<http://www.scielo.br/scielo.php?script=sci_arttext\&pid=S0101-73302006000400004 > Acesso em:20 jan. 2016.

BEM, A. S. A centralidade dos movimentos sociais na articulação entre o Estado e a sociedade brasileira nos séculos XIX e XX. Educação \& Sociedade, v. 27, n. 97, 2006. p.1137-1157

BITTENCOURT, C. Livros didáticos entre textos e imagens. In: O saber histórico na sala de aula. São Paulo: Contexto, 2002. p. 112-130.

BITTENCOURT, C. M. F. Livro didático e conhecimento histórico: uma história do saber escolar. 1993, 369f. Tese (Doutorado em História Social). Faculdade de Filosofia, Letras e Ciências Humanas, Universidade de São Paulo, São Paulo, 1993.

BLUNT, W. El Naturalista: vida, obra y viajes de Carl von Linné, Barcelona: Ediciones del Serbal, 1982.

BORGES, Marley de Fátima Moraes. O Ensino de História, Cultura Africana e AfroBrasileira, na perspectiva da Lei $\mathbf{N}^{\circ}$ 10.639/2003: análise de políticas públicas na EE. Prof. Hélio Palermo. 2016. 125f. Dissertação. (Mestrado Profissional em Políticas Públicas) Faculdade de Ciências Humanas e Sociais, Universidade Estadual Paulista, Franca, 2016.

BOURDIEU, P.; CHAMPAGNE, P. P. Os três estados do capital cultural. Castro, M. (trad.) In.: NOGUEIRA, M.A; CATANI, A.M (Org.). Escritos de educação. Petrópolis, RJ: Vozes, p. 71-79, 1998.

BRASIL, Constituição da República Federativa do Brasil. Diário Oficial da União. Brasília, 05 out. 1988, seção1. Disponível em: < http://www2.camara.leg.br/legin/fed/consti/1988/constituicao-1988-5-outubro-1988-322142publicacaooriginal-1-pl.html > Acesso em: 14 set. 2017.

Decreto 7.480/2011. Aprova a estrutura regimental e o quadro demonstrativo dos cargos em comissão do grupo - direção e assessoramento superiores - das funções gratificadas do Ministério da Educação e dispõe sobre remanejamento de cargos em comissão. Diário Oficial da União, Brasília, 17 mai. 2011, seção 1.

Decreto 7.690/2012. Aprova a estrutura regimental e o quadro demonstrativo dos cargos em comissão e das funções gratificadas do Ministério da Educação. Diário Oficial da União, Brasília, 06 mar. 2012, seção 1. p 15. 
Definição de critérios para avaliação dos livros didáticos. Brasília: FAE, 1994. Disponível em : <http://www.dominiopublico.gov.br/download/texto/me002396.pdf> .Acesso em: 05 mar. 2017. 1999.

Diagnóstico do Setor Editorial Brasileiro. Belo Horizonte: Fundação João Pinheiro,

Guia de Livro Didáticos. $1^{\mathrm{a}}$ a $4^{\mathrm{a}}$ séries. Ministério da Educação. Fundo Nacional de Desenvolvimento Educacional PNLD, 1997. Brasília: MEC, 1996 Disponível em: <http://www.fnde.gov.br/programas/livro-didatico/livro-didatico-historico> Acesso em: 30 jan. 2017.

Guia de Livro Didáticos. $1^{\mathrm{a}}$ a $4^{\mathrm{a}}$ séries. Ministério da Educação. Fundo Nacional de Desenvolvimento Educacional PNLD, 1998. Brasília: MEC, 1997 Disponível em: <http://www.fnde.gov.br/programas/livro-didatico/livro-didatico-historico> Acesso em: 01 fev. 2017.

Guia de Livro Didáticos. $1^{\mathrm{a}}$ a $4^{\mathrm{a}}$ séries. Ministério da Educação. Fundo Nacional de Desenvolvimento Educacional PNLD, 2000. Brasília: MEC, 2001 Disponível em: <http://www.fnde.gov.br/programas/livro-didatico/livro-didatico-historico $>$ Acesso em: 02 fev. 2017.

Guia de Livro Didáticos. $1^{\mathrm{a}}$ a $4^{\mathrm{a}}$ séries. Ministério da Educação. Fundo Nacional de Desenvolvimento Educacional PNLD, 2004. Brasília: MEC, 2003 Disponível em: $<$ http://www.fnde.gov.br/programas/livro-didatico/livro-didatico-historico $>$ Acesso em: 04 fev. 2017.

Guia de Livros didáticos. $1^{\mathrm{a}}$ a $4^{\mathrm{a}}$ séries. Ministério da Educação. Fundo Nacional de Desenvolvimento Educacional PNLD 1998. Brasília: MEC, 1997. Disponível em: <http://www.dominiopublico.gov.br/download/texto/me002406.pdf $>$ Acesso em: 06 mar. 2017.

Guia de Livros didáticos. $5^{\mathrm{a}}$ a $8^{\mathrm{a}}$ séries. Ministério da Educação. Fundo Nacional de Desenvolvimento Educacional PNLD 1999. Brasília: MEC, 1998. Disponível em: <http://portal.mec.gov.br/seb/arquivos/pdf/Avalmat/pnldapres07.pdf> Acesso em: 08 mai. 2017.

. Guia de Livro Didáticos. $5^{\mathrm{a}}$ a $8^{\mathrm{a}}$ séries. Ministério da Educação. Fundo Nacional de Desenvolvimento Educacional. PNLD, 2005. Brasília: MEC, 2004. Disponível em: $<$ http://www.fnde.gov.br/programas/programas-do-livro/livro-didatico/guia-do-livrodidatico/item/8792-guia-pnld-2005> Acesso em: 18 mar. 2017.

Lei n. 1.187, de 13 de setembro de 1996. Diário Oficial do Distrito Federal, Brasília, 14 set.1996. Seção 1.Disponível em: < http://www.lexml.gov.br/urn/urn:lex:br;distrito.federal:distrital:lei:1996-09-13;1187>. Acesso em: 14 fev. 2017. 
Lei $n^{\circ}$ 4.024, de 20 de dezembro de 1961. Fixa as diretrizes e bases da educação nacional. Lei de Diretrizes e Bases da Educação-LDB. Diário Oficial da União, Brasília, 18 dez. 1961, Seção 1. Disponível em: 〈 http://www.planalto.gov.br/Ccivil 03/leis/L9394.htm> Acesso em: 14 set. 2014.

Lei ${ }^{\circ}$ 9.394, de 20 de dezembro de 1996. LDB: Lei das Diretrizes e Bases da Educação nacional. Estabelece as diretrizes e bases da educação nacional. Diário Oficial da União, Brasília, 23 dez, 1996. Seção 1. Disponível em:

<http://portal.mec.gov.br/arquivos/pdf/ldb.pdf> Acesso em: 01 dez. 2014.

Lei $\mathrm{n}^{\circ} .10 .639$ de 09 de janeiro de 2003. Inclui a obrigatoriedade da temática "História e Cultura Afro-Brasileira" no currículo oficial da rede de ensino. Diário Oficial da União, Brasília, 10 jan. 2003. Seção 1. Disponível em: < http://www.planalto.gov.br/CCivil_03/leis/2003/L10.639.htm> Acesso em: $10 \mathrm{dez} 2017$.

Lei n. ${ }^{\circ} 10.639$, de 9 de janeiro de 2003 - Veto. Diário Oficial da União, Brasília, 10 jan. 2003. Seção 1. Disponível em <http://www2.camara.leg.br/legin/fed/lei/2003/lei-106399-janeiro-2003-493157-veto-13762-pl.html> Acesso em: 21 abr. 2018.

. Medida Provisória n ${ }^{\circ} 111$, de 21 de marco 2003 - Cria a Secretaria Especial de Políticas de Promoção da Igualdade Racial, da Presidência da República, e dá outras providências. Diário Oficial da União, Brasília, 21 mar 2003. Seção 1. Disponível em: < http://www2.camara.leg.br/legin/fed/medpro/2003/medidaprovisoria-111-21-marco-2003496057-publicacaooriginal-1-pe.html> Acesso em: 10 fev. 2018.

Ofício n. 1462, de 09 de janeiro de 2003. Presidência da República. Legislação Informatizada. Câmara dos Deputados - LEI No 10.639, DE 9 DE JANEIRO DE 2003 Veto. Disponível em <http://www2.camara.leg.br/legin/fed/lei/2003/lei-10639-9-janeiro2003-493157-veto-13762-pl.html > Acesso em: 21 abr. 2018.

Pareceres e Resoluções sobre Educação das Relações Étnico Raciais. Ministério da Educação [website]. Disponível em <http://portal.mec.gov.br/programa-saude-da-escola/323secretarias-112877938/orgaos-vinculados-82187207/12988-pareceres-e-resolucoes-sobreeducacao-das-relacoes-etnico-raciais> Acesso em: 23 dez. 2017.

Parecer $\mathrm{CNE} / \mathrm{CEB} \mathrm{n}^{\circ} 15$, de 01 de setembro de 2010. Orientações para que a Secretaria de Educação do Distrito Federal se abstenha de utilizar material que não se coadune com as políticas públicas para uma educação antirracista. Ministério da Educação .Disponível em: <http://portal.mec.gov.br/secretaria-de-regulacao-e-supervisao-daeducacao-superior-seres/323-secretarias-112877938/orgaos-vinculados-82187207/15074-ceb2010-sp-1493348564> Acesso em: 28 dez. 2017.

Parecer CNE/CEB n ${ }^{\circ}$ 16, de 01 de setembro de 2010. Denúncia de racismo na Escola Estadual Delmira Ramos dos Santos, localizada no Bairro Coophavilla II, Município de Campo Grande, MS. Ministério da Educação. Disponível em:

$<$ http://portal.mec.gov.br/secretaria-de-regulacao-e-supervisao-da-educacao-superiorseres/323-secretarias-112877938/orgaos-vinculados-82187207/15074-ceb-2010-sp1493348564> Acesso em: 28 dez. 2017. 
Parecer $n^{\circ}$ CNE/CP 003/2004, de 10 de março de 2004. Diretrizes curriculares nacionais para a educação das relações étnico-raciais e para o ensino de história e cultura afrobrasileira e africana. Diário Oficial da união, Brasília, 19 mai. 2004. Seção 1. Disponível em: $<$ http://portal.mec.gov.br/conselho-nacional-de-educacao/atos-normativos--sumulaspareceres-e-resolucoes> Acesso em: 14 set 2017.

. Sobre a SEPPIR. Secretaria de Promoção de políticas de Igualdade Racial [website]. Disponível em: < http://www.seppir.gov.br/sobre-a-seppir/a-secretaria > Acesso em: 06 abr. 2018.

Lei n. ${ }^{\circ}$ 10.639, de 9 de janeiro de 2003 - Veto. Diário Oficial da União, Brasília, 10 jan. 2003. Seção 1. Disponível em <http://www2.camara.leg.br/legin/fed/lei/2003/lei-106399-janeiro-2003-493157-veto-13762-pl.html> Acesso em: 21 abr. 2018.

Projeto de lei n. 259, de 11 de marco de 1999. Dispõe sobre a obrigatoriedade da inclusão, no currículo oficial da Rede de Ensino, da temática "História e Cultura AfroBrasileira" e dá outras providências. Câmara dos Deputados. [Website]. Disponível em: $\langle$ http://www.camara.gov.br/proposicoesWeb/fichadetramitacao?idProposicao=15223 > Acesso em: 14 abr. 2018.

BUARQUE, C. O que é apartação: O apartheid social no Brasil. Rio de janeiro: Editora brasiliense, 2003. (Primeiros passos, 278)

BUENO, S. F. Semicultura e educação: uma análise crítica da revista Nova Escola. Revista Brasileira de Educação, v. 12, n. 35, p. 300-307, maio/ago, 2007.

CAMARA DOS DEPUTADOS [website]. Biografias. Esther Grossi. Disponível em: $<$ http://www2.camara.leg.br/deputados/pesquisa/layouts_deputados_biografia?pk=73894\&tip $\underline{\mathrm{o}=1}>$ Acesso em: 19 abr. 2018.

Benedita da Silva. Disponível em:

< http://www.camara.leg.br/Internet/Deputado/dep_Detalhe.asp?id=73701 > Acesso em: 20 abr. 2018.

Evandro Milhomen. Disponível em:

$<$ http://www2.camara.leg.br/deputados/pesquisa/layouts_deputados_biografia?pk=74345\&tip $\underline{\mathrm{o}=1}>$ Acesso em: 18 abr. 2018.

CARVALHO, M. M. C. de. A Escola e a república e outros ensaios. Bragança Paulista: USF, 2003.

CARVALHO, O. Porque não sou um fã de Charles Darwin. Diário do Comércio, São Paulo, 20 de fevereiro, 2009. Disponível em < http://www.olavodecarvalho.org/por-que-nao-souum-fa-de-charles-darwin/> Acesso em: 01 mai. 2017.

CAVALCANTI, Maria Laura Viveiros de Castro. O aspecto humano de nossos dados: a relação Pierson/Nogueira, a etnografia e a abordagem das relações raciais. Ideais de 
modernidade e sociologia no Brasil: ensaios sobre Luiz de Aguiar Costa Pinto, Porto Alegre, Ed. da UFRGS, p. 185-202, 1999.

CHIZZOTTI, A. Deve ser obrigatório o ensino da história afro brasileira? Revista Nova Escola, São Paulo, Edição 177, 2004.

CONVENÇÃO NACIONAL DO NEGRO PELA CONSTITUINTE, p. 4, Brasília - DF, 26 e 27 de agosto, 1986.

CRUZ, Mariléia dos Santos. A história da disciplina Estudos Sociais a partir de representações sobre o negro no livro didático (período 1981-2000). 2018. 235f. Dissertação (Mestrado em Educação), Faculdade de Filosofia e Ciência, Universidade Estadual Paulista, 2018.

CURITIBA. Secretaria de Estado da Educação, Superintendência de Educação. inserção dos conteúdos de história e cultura afro-brasileira e africana. Cadernos temáticos. Curitiba: SEED, 2005. $<$ http://www.educadores.diaadia.pr.gov.br/modules/conteudo/conteudo.php?conteudo=764> Acesso em: 25 mar. 2018.

DARWIN, C. A origem das espécies. São Paulo: Martin Claret, 2014.

DARWIN, C. The descente of man (1871). In GOULD, S. J. A falsa medida do homem. São Paulo, Martins Fontes, 2014. p 127.

DIAS, L.R. Quantos passos já foram dados? A questão de raça nas leis educacionais - da LDB de 1961 à Lei 10.639, de 2003. In: ROMÃO, J. (Org.). História da educação dos negros e outras histórias. Brasília, DF: MEC; SECAD, 2005. p.49-62.

DOMINGUES, P. A nova abolição. São Paulo: Selo Negro, 2008.

Movimento negro brasileiro: alguns apontamentos históricos. Tempo [online]. 2007, v.12, n.23, p.100-122.

EDUCAÇÃO. Crianças de países africanos se sentem mais satisfeitas na escola. Revista Educação[website]. 2015. Disponível em: 〈http:// revistaeducacao.com.br/criancas-depaises-africanos-se-sentem-mais-satisfeitas-na-escola $>$ Acesso em: 12 jan. 2018.

Curso sobre história e cultura africana tem inscrições abertas na USP. Revista Educação [website]. 2016. Disponível em: <http:// revistaeducacao.com.br/curso-sobrehistoria-e-cultura-africana-tem-inscricoes-abertas-na-usp> Acesso em: 14 mar. 2018.

Ensino de cultura e história afro e indígena ainda enfrenta obstáculos no Brasil.

Revista Educação [website]. 2016. Disponível em: < htpp:// revistaeducacao.com. br/ensinode-cultura-e-historia-afro-e-indigena-ainda-enfrenta-obstaculos-no-brasil> Acesso em: 12 jan. 2018. 
EXECUTIVA NACIONAL DA MARCHA ZUMBI. Por uma política nacional de combate ao racismo e à desigualdade racial: Marcha Zumbi contra o racismo, pela cidadania e vida. Brasília: Cultura Gráfica e Editora, p. 19, 1996.

FÉRES, M.J.V. A. Deve ser obrigatório o ensino da história afro brasileira? Revista Nova Escola, São Paulo, Edição 177, 2004.

FERNANDES, F. A integração do negro na sociedade de classes. 3. ed. São Paulo: Ática, 1962, 1 Vols.

A integração do negro à sociedade de classes. Faculdade de Filosofia, Ciências e Letra da Universidade de São Paulo, 1965, 2 vols.

F.; BASTIDE, R. Relações raciais entre negros e brancos em São Paulo. São

Paulo: Editora Anhembi, 1955.

FERREIRA, A. R. Seis leituras essenciais para lidar com o racismo na Educação Infantil.

Nova Escola, 2016. Disponível em: < https://novaescola.org.br/conteudo/3371/blog-leituraessenciais-racismo-educacao > Acesso em: 14 mar. 2018.

FERREIRA, Cléa Maria da Silva. Formação de Professores à luz da História e Cultura Afro-brasileira e Africana: novas tendências, novos desafios para uma prática reflexiva. 2009. 230f. 2009. Tese de Doutorado. Dissertação (Mestrado em Educação). Faculdade de Educação, Universidade de São Paulo, São Paulo, 2009.

FUNDAÇÃO GETÚLIO VARGAS MODERNA. [website]. Centro de Pesquisa e Documentação de História Contemporânea do Brasil. Acervo biográfico. Adalberto Camargo. Disponível em: <http://www.fgv.br/cpdoc/acervo/dicionarios/verbete-biografico/camargoadalberto> Acesso em: 28 mar. 2018.

Ben - Hur Ferreira. Disponível em:

< http://www.fgv.br/cpdoc/acervo/dicionarios/verbete-biografico/ferreira-ben-hur $>$ Acesso em: 20 mar. 2018.

FREIRE, P. Pedagogia da Autonomia: saberes necessários à prática educativa. São Paulo: Paz e Terra, 1996.

FOUCAULT, Michel. Microfísica do poder. Organização e tradução de Roberto Machado. Rio de Janeiro: Edições Graal, 1979.

A ordem do discurso. São Paulo: Loyola, 1996.

FREYRE, G. Casa Grande e Senzala. 46. ed. Rio de Janeiro: Record, 2002.

FREZZATTI Jr., W. A. A construção da oposição entre Lamarck e Darwin e a vinculação de Nietzsche ao eugenismo. Scientiae Studia, v. 9, n. 4, p. 791-820, 2011. 
GATAMORTA, L. Ensino de cultura e história afro e indígena ainda enfrenta obstáculos no Brasil. Revista Educação [website]. 2016. Disponível em: < htpp:// revistaeducacao.com.br/ensino-de-cultura-e-historia-afro-e-indigena-ainda-enfrentaobstaculos-no-brasil> Acesso em: 12 jan. 2018.

GENTIL, M. S. Revistas da área da educação e professores - interlocuções. 2006. $288 \mathrm{f}$. Tese (Doutorado). Universidade Estadual de Campinas, Faculdade de Educação. Campinas, SP, 2006.

GENTILI, P. África de todos nós. Nova Escola, 2005. Disponível em: < novaescola.org.br/conteudo/2393/africa-de-todos-nos> Acesso em: 12 abr. 2018. p.14, 2005.

Um jogo de tabuleiro que veio da África. Nova Escola. São Paulo: Ed. Abril, n. 64,

GOBINEAU, J. A. Essai sur l'inégalité des races humaines (1853) p. 539. A tela da reflexão. Disponível em <http://manmessias21.blogspot.com.br/2013/05/a-miscingenacao-do-brasilsob-o-olhar.html> Acesso em: 21 mai. 2018.

1937.

Ensayo sobre la desigualdad de la srazas humanas. Barcelona: Editorial Apolo,

GOMES, J. B. B. Ação Afirmativa \& Princípio Constitucional da Igualdade: o direito como instrumento de transformação social. A experiência dos EUA. Rio de Janeiro: Renovar, 2001.

. ; JESUS, R. E. As práticas pedagógicas de trabalho com relações étnico-raciais na escola na perspectiva de Lei 10.639/2003: desafios para a política educacional e indagações para a pesquisa. Educar em Revista, v. 29, n. 47, p. 19-33, 2013.

GONÇALVES, Luciane Ribeiro Dias. Representações sociais sobre educação étnico-racial de professores de Ituiutaba - MG e suas contribuições para a formação docente. 2011. 168 f. Tese (Doutorado em Educação). Campinas, Universidade Estadual de Campinas, 2011.

GOULD, S. A falsa medida do homem. São Paulo: Martins Fontes, 2014. 127.

Ontogeny and Phylogeny (Cambridge, Mass: Harvard University Press, 1977), p.

GOUVÊA, M. C. S.; GERKEN, C. H. S. Desenvolvimento humano: história, conceitos e polêmicas. São Paulo: Cortez, 2010.

GUIMARÃES, A. S. A. Classes, raças e democracia. São Paulo: Fundação de Apoio à Universidade de São Paulo. Ed. 34, 2002. 
HUMPHRIES, C. J.; HUXLEY, R. Carl Linnaeus: The man who brought order to nature. The great naturalists, p. 132-139, 2007.

INSTITUTO BRASILEIRO DE GEOGRAFIA E ESTATÍSTICA. Brasil: 500 anos de povoamento. Rio de Janeiro: 2000. Disponível em <https://www.ibge.gov.br/estatisticasnovoportal/sociais/populacao/9372-caracteristicas-etnico-raciais-da-populacao.html $?=\& \mathrm{t}=\mathrm{o}-$ que-e> Acesso em: 12 out. 2017.

INSTITUTO BRASILEIRO DE GEOGRAFIA E ESTATÍSTICA - IBGE. Censo Demográfico, 2010. Disponível em: < https://censo2010.ibge.gov.br/> Acesso em: 14 dez. 2017.

INSTITUTO BRASILEIRO DE GEOGRAFIA E ESTATÍSTICA - IBGE. IBGE divulga resultados de Estudo sobre cor e raça, 2015. Disponível em: < https://agenciadenoticias.ibge.gov.br/agencia-sala-de-imprensa/2013-agencia-denoticias/releases/14057-asi-ibge-divulga-resultados-de-estudo-sobre-cor-ou-raca $>$ Acesso em: 15 dez. 2017.

INSTITUTO DE PESQUISA ECONOMICA APLICADA. Retrato das Desigualdades de Gênero e Raça com base em séries históricas de 1995 a 2015. Brasília: 2017. Disponível em < http://www.ipea.gov.br/portal/index.php?option=com content $\&$ view=article\&id=29526 $>$. Acesso em:

JANZ, Rubia Caroline. Dez anos da Lei 10.639/03: o que mudou nos livros didáticos de História? Uma proposta de análise. Anais do XV Encontro Estadual de História, p. 1-13, 2014.

LEITE, C.R.S.C. 1.888: a Abolição foi feita! E agora? Disponível em <http://www.afropress.com/post.asp?id=20467> Acesso em: 22 de mai. 2018.

LEME, Andressa Caroline Francisco. Agora é para alfabetizar, sim ou não? Análise dos discursos especializados sobre a idade certa para iniciar a alfabetização no contexto da ampliação do ensino fundamental para nove anos. 2015. 105f. Dissertação (Mestrado em Estudos Culturais). São Paulo, Escola de Artes, Ciências e Humanidades, São Paulo, 2015. Versão corrigida.

LIMA, M. N. M. Identidades e cultura afro-brasileira: a formação de professoras na escola e na universidade, 2007.224f. Tese (Doutorado em Letras). Salvador, Instituto de Letras, Universidade Federal da Bahia, 2007.

LIPPOLD, W. G. R. A África no curso de licenciatura em história da Universidade Federal do Rio Grande do Sul: possibilidades de efetivação da Lei 11.645/2008 e da Lei 10.639/2003: um estudo de caso, 2008.

LOBATO. M. Caçadas de Pedrinho. Rio de janeiro: Globo, 2009.

LUCIANO, Tiago Ricardo. Currículo e reprodução da desigualdade: análise da Proposta Curricular do estado de São Paulo para a disciplina de História. 2016. 122f. Dissertação 
(Mestrado em Educação). -Universidade Estadual Paulista “Julio de Mesquita Filho", Bauru, 2016.

LUIZ, M. F. Educação das relações étnico-raciais: contribuições de cursos de formação continuada para professoras (es). 2013. 138f. Dissertação (Mestrado em Educação). São Carlos, Universidade Federal de São Carlos, 2013.

MARINGONI, G. O destino dos negros após a abolição. Revista Desafios do Desenvolvimento. Disponível

em: < http://www.ipea.gov.br/desafios/index.php?option=com_content\&id=2673\%3Acatid\% 3D28\&Itemid=23> Acesso em: 25 fev. 2018.

MINISTERIO DA EDUCAÇÃO. Livros Didáticos: Governo federal compra 88\% da produção de obras escolares. Disponível em <

http://portal.mec.gov.br/component/content/article?id=15438:governo-> Acesso em: 30 jan. 2017.

MODERNA. [website]. Catálogo didático e paradidático. Disponível em: < https://www.moderna.com.br/main.jsp?lumPageId=4028818B2E3AAEB2012E49CCECE92E 58\&IdColecaoCatalogo=75021F964D094BA2BCD376C6A6C38AA8> Acesso em: 12 out. 2017.

MOTA, Edimilson Antônio. O negro e a cultura afro-brasileira: uma bricolagem multicultural do ensino de geografia. 2013, 222f. Tese (Doutorado em Educação) Faculdade de Educação, Universidade Federal do Rio de Janeiro, Rio de Janeiro. Disponível em: < http://www.educacao.ufrj.br/tedmilsonmota.pdf > Acesso em: 25 abr. 2016.

MUNANGA, K. (Org.). Estratégias e políticas de combate à discriminação racial. São Paulo: EDUSP/Estação Ciências, 1996.

MUSEU AFRO BRASIL. História e memória. [web sites]. Abdias do Nascimento. Disponível em: < http://www.museuafrobrasil.org.br/pesquisa/hist\%C3\%B3ria-emem\%C3\%B3ria/historia-e-memoria/2014/12/10/abdias-nascimento > Acesso em: 25 jun. 2018.

NASCIMENTO, A. Teatro experimental do negro: trajetória e reflexões. Estudos Avançados. São Paulo, USP, vol.18, n.50, jan.-br. 2004. pp. 209-224. Disponível em: < http://www.scielo.br/scielo.php?script=sci_arttext\&pid=S0103-40142004000100019 >. Acesso em: 25 set. 2010.

NEXO EXPRESSO. Quem foi Caó, autor da lei que definiu o crime de racismo no Brasil. Disponível em < https://www.nexojornal.com.br/expresso/2018/02/05/Quem-foi-

Ca\%C3\%B3-autor-de-lei-que-definiu-o-crime-de-racismo-no-Brasil > Acesso em: 25 mar. 2018.

NOVA ESCOLA. Quem somos nós. São Paulo: Ed. Abril, n. 169, p. 6, 2004. 
NOVA ESCOLA. Nossa história. Nova Escola, 2016. Disponível em <https://novaescola.org.br/quem-somos> Acesso em: 29 mai. 2018.

NUNES, Erica Melanie Ribeiro. Cidadania e multiculturalismo: a lei 10.639/03 no contexto das bibliotecas municipais de Belo Horizonte. 2010 140f. Dissertação (Mestrado em Ciência da Informação). Belo Horizonte, Escola de Ciência da Informação, Universidade Federal de Minas Gerais, 2010.

OLIVEIRA, M. A. O negro no ensino de história: temas e representações. 2010, Dissertação (Mestrado em Educação), São Paulo, Universidade de São Paulo, 2000.

PARTIDO DOS TRABALHADORES. Paulo Paim. Disponível em <http://www.pt.org.br/paulo-paim/> Acesso em: 04 de abril de 2018.

PATTO, M. H. S. Escolas cheias, cadeias vazias: nota sobre as raízes ideológicas do pensamento educacional brasileiro. Estudos avançados, v. 21, n. 61, p. 243-266, 2007.

PAZZINATO, A. L. \& SENISE, M. H. V. História Moderna e Contemporânea. São Paulo: Ática, 2002, p. 226.

PECHI, D. A história da África em sala. Nova Escola, 2011. Disponível em:

$<$ http://novaescola.org.br/conteudo/1422/a-historia-da-africa-em-sala $>$ Acesso em: 16 mar. 2018.

PINHEIRO, Juliano Soares. Aprendizagens de um grupo de futuros (as) professores (as) de química na elaboração de conteúdos pedagógicos digitais: em face dos caminhos abertos pela Lei Federal no 10.639 de 2003. 2009, 202f. Dissertação (Mestrado em Química). Uberlandia, Universidade Federal de Uberlandia, 2009.

PIRES DE ALMEIDA, J.R. Históire the l'instruction Publique au Brésil (1889). In PATTO. Escolas cheias cadeias vazias: Notas sobre as raízes ideológicas do pensamento educacional brasileiro. Estudos Avançados/USP. São Paulo. Disponível em <http://www.revistas.usp.br/eav/article/view/10278/11921> Acesso em: 14 set. 2017.

POLIAKOV, L. O mito ariano. São Paulo: Edusp, 1974.

QUILOMBO. Coluna Nosso Programa. Rio de Janeiro, ano III, n. 11, 09 dez.1950, p.3. Disponível em < http://ipeafro.org.br/acervo-digital/leituras/ten-publicacoes/jornal-quilombono-01/> Acesso em: 25 mar. 2017.

QUILOMBO. Coluna Nosso Programa. In SANTOS, A. S. A Lei 10.639/2003 como fruto da luta anti - racista do movimento negro em Educação anti-racista: caminhos abertos pela Lei Federal 10.639/2003. Coleção Educação para todos. MEC/BID/UNESCO. Brasília, 2005. 
para Todos - Brasília: Ministério da Educação, Secretaria de Educação Continuada, Alfabetização e Diversidade, 2005.

REIS, R. C. da C. Leitura Imagética, Relações Étnico-raciais e Formação de Professores de Línguas. In: CASTILHO, Maria Roseli; FERREIRA, Aparecida de Jesus (org). Formação de Professores de Línguas: investigações e intervenções. EDUNIOESTE. Cascavel, 2009.

RIBEIRO, D. O povo brasileiro: a formação e o sentido do Brasil. São Paulo: Conpanhia das Letras, 1995.

SANTANA, Jair. A lei 10.639/03 e o ensino de artes nas séries iniciais: políticas afirmativas e folclorização racista. 2010. 248f. Tese (Doutorado em Educação). Curitiba, Universidade Federal do Paraná, 2010.

SANTOS, R. A. Estado do conhecimento da área de educação e Relações raciais em programas de pós-graduação em Educação (2000-2010). ANPAE, $25^{\circ}$ simpósio brasileiro de política e administração da educação, 2011. Disponível em:

<http://www.anpae.org.br/simposio2011/cdrom2011/PDFs/trabalhosCompletos/comunicacoe sRelatos/0448.pdf > Acesso em: jan. 2016

SANTOS, S. A. A lei no 10.639/03 como fruto da luta anti-racista do Movimento Negro. In: Educação anti-racista: caminhos abertos pela Lei Federal $n^{\circ} 10.639 / 03$. Coleção para todos. Brasília: MEC/SECAD, 2005.

SANTOS, U. G. Livros didáticos: contribuição para a aplicação no ensino de história e cultura afro-brasileira em instituições de ensino públicos e particulares. Revista África e Africanidades - Ano 3 - n. 10, agosto, 2010.

SCHWARCZ, L. M. Espetáculo da miscigenação. In: Estudos Avançados/USP, vol.8 n²0. São Paulo, Jan./Apr. 1994, pg. 146-147.

SCHWARCZ, L. M. O Espetáculo das Raças: cientistas, instituições e questão racial no Brasil 1870-1930. São Paulo: Companhia das Letras, 1993.

SENADO FEDERAL. Morre o ex-senador e ativista Abdias Nascimento. Disponível em $<$ https://www12.senado.leg.br/noticias/materias/2011/05/24/morre-ex-senador-e-ativistaabdias-nascimento > Acesso em: 02 abr. 2018.

SILVA, A. C. A ideologia do embranquecimento na educação brasileira e proposta de revisão. In: MUNANGA, K. (Org.). Estratégias e políticas de combate à discriminação racial. São Paulo: EDUSP/Estação Ciências, 1996.

A discriminação do negro no livro didático. Salvador: CED - Centro Editorial Didático e CEAO - Centro de Estudos Afro - Orientais, 1995, p 34; 47; 135. 
Estereótipos e Preconceitos em relação ao negro no livro de comunicação e Expressão de $1^{a}$ grau nível 1. Dissertação de mestrado apresentada na FACED/UFBA, Salvador, 1988. Disponível em< http://publicacoes.fcc.org.br/ojs/index.php/cp/article/view/1282/1283> Acesso em: 23 jan. 2018.

SILVA, Gizelda Costa da. O estudo da história e cultura afro-brasileira no ensino fundamental: currículos, formação e prática docente. 2011, 212f. Tese (Doutorado em Ciências Humanas). Uberlandia, Universidade Federal de Uberlândia, 2011.

SILVA, JR. H. Anti-Racismo: Coletânea de Leis Brasileiras - Federais, Estaduais e Municipais. São Paulo: Editora Oliveira Mendes, 1998.

SILVA, P. V. B. Racismo em livros didáticos: Estudo sobre negros e brancos em livros didáticos. Belo Horizonte: Autêntica, 2008.

SILVA, R. S. A afro descendência nas investigações científicas: uma década da implementação da lei 10.639/2003. Revista Espaço do Currículo, Paraíba. Disponível em <http://periodicos.ufpb.br/ojs/index.php/rec/article/view/22222> Acesso em: 20 jun. 2017.

SKIDMORE, T. E. Preto no Branco: Raça e nacionalidade no pensamento brasileiro. Rio de Janeiro: Paz e Terra. 1976.

SOUSA, R. O conde de Gobineau e o horror à ambivalência. Usos do Passado - XII Encontro regional de História, ANPUH/RJ, 2006, p. 1-6.

TEATRO EXPERIMENTAL NEGRO. Enciclopédia Itaú Cultural. Disponível em: <http://enciclopedia.itaucultural.org.br/grupo399330/teatro-experimental-do-negro>. Acesso em: 18 nov. 2017.

TEIXEIRA, L. Práticas para discutir racismo e identidade na sala de aula. Nova Escola, 2016. Disponíve em: <https://novaescola.org.br/conteudo/9117/6-praticas-para-discutir-racismo-eidentidade-na-sala-de-aula $>$ Acesso em: 12 jan. 2018.

TELLES, E. Racismo à brasileira: uma nova perspectiva sociológica. Rio de Janeiro: Relume-Dumará: Fundação Ford, 2003. 347 p.

TONINI, R. A Arte Perniciosa: a repressão Penal aos Capoeiras na República Velha. Rio de Janeiro: Lumen Juris, 2008.

UNIVERSIDADE FEDERAL DE SÃO CARLOS [website]. Biografias. Petronilha Beatriz Golçalves e Silva. Disponível em: 〈http://www.ufscar.br/ defmh/spqmh/bio_petro.html> Acesso em: 12 dez. 2017.

SENADO FEDERAL [website]. Senadores. Humberto Costa. Disponível em: < https:// https://www25.senado.leg.br/web/senadores/senador/-/perfil/5008 > Acesso em: 17 mar. 2018 
Nilma Lino Gomes. Disponível em< http://www.seppir.gov.br/central-deconteudos/noticias/outubro/nilma-lino-gomes-e-indicada-como-titular-do-ministerio-dasmulheres-igualdade-racial-e-direitos-humanos > Acesso em: 12 dez. 2017.

XAVIER, Andreza Santos. A imagem do negro em manuais para o professor: uma análise linguístico-discursiva e ideológica. 2011, 176f. Dissertação (Mestrado em Linguística).Belo Horizonte, Universidade Federal de Minas gerais, 2011. 
ANEXO 1 - SÍNTESE SOBRE LEGISLAÇÕES VOLTADAS ÀS POLÍTICAS DO LIVRO DIDÁTICO NO BRASIL

\begin{tabular}{|c|c|c|c|}
\hline Órgão & Regulamento e Período & Objetivo & Resultados \\
\hline $\begin{array}{l}\text { Comissão Nacional do Livro } \\
\text { Didático }\end{array}$ & $\begin{array}{l}\text { Decreto - Lei n. 1.006,0de } \\
\text { 30/12/1938. }\end{array}$ & $\begin{array}{l}\text { Estabelecer condições para produção, importação e utilização } \\
\text { do livro didático. }\end{array}$ & $\begin{array}{l}\text { Função muito mais de controle político-ideológico que de } \\
\text { controle didático (Freitag, Motta e Costa, 1989). }\end{array}$ \\
\hline CNLD & $\begin{array}{l}\text { Decreto - Lei n.8.460, de } \\
1945 .\end{array}$ & $\begin{array}{l}\text { Deliberação sobre processos de autorização para adoção e uso } \\
\text { do livro didático; deliberação sobre atualização e substituição } \\
\text { dos mesmos; deliberação de precauções em relação á } \\
\text { especulação comercial. }\end{array}$ & $\begin{array}{l}\text { Mantém a centralização, os poderes e problemas da CNLD } \\
\text { (Freitag, Motta e Costa, 1989). }\end{array}$ \\
\hline $\begin{array}{l}\text { Comissão do Livro Técnico } \\
\text { do livro Didático/COLTED }\end{array}$ & $\begin{array}{l}\text { Decreto n. 59.355, de } \\
\text { 04/10/1966. (acordo MEC - } \\
\text { SNEL - USAID). }\end{array}$ & $\begin{array}{l}\text { "Incentivar, avaliar, orientar, coordenar, executar, produzir, } \\
\text { editar, aprimorar e distribuir livros técnicos e didáticos" (Cruz, } \\
\text { 2000, p. 55). }\end{array}$ & $\begin{array}{l}\text { Assegurou a distribuição de } 51 \text { milhões de livros nos três anos } \\
\text { subsequentes. Comprou livros obsoletos, "salvando" editoras } \\
(\text { Cruz, 2000). }\end{array}$ \\
\hline $\begin{array}{l}\text { Programa do } r \text { Livro } \\
\text { Didático/PLID, } \\
\text { reponsabilidade do Instituto } \\
\text { Nacional do Livro/INL. }\end{array}$ & $\begin{array}{l}\text { Decreto n. 68.728, de } \\
\text { 08/06/1971. }\end{array}$ & $\begin{array}{l}\text { Assumir atribuições administrativas e de gerenciamento dos } \\
\text { recursos financeiros. }\end{array}$ & $\begin{array}{l}\text { Necessidade de contrapartida financeira estadual com o fim do } \\
\text { acordo MEC/SNEL/USAID (Castro, 1996). }\end{array}$ \\
\hline $\begin{array}{lc}\text { Fundação } & \text { nacional } \\
\text { material } & \text { Escolar/FENAME } \\
\text { passa a } & \text { responsável pelo } \\
\text { PLID } & \end{array}$ & $\begin{array}{l}\text { Decreto n. } 77.107, \text { de } \\
\text { 04/02/1976. }\end{array}$ & $\begin{array}{l}\text { Formular programa editorial; executar os programas do livro } \\
\text { didático; definir diretrizes para a produção de material didático } \\
\text { e assegurar sua distribuição: cooperar com as instituições, } \\
\text { públicas e privadas, na execução de objetivos comuns. }\end{array}$ & $\begin{array}{l}\text { A grande maioria das escolas públicas municipais foi excluída } \\
\text { do Programa, devido a insuficiência dos recursos e por ter } \\
\text { ficado a cargo das secretarias estaduais o critério do corte } \\
\text { (Castro, 1996). O Programa de Criação e Bibliotecas nos } \\
\text { Municípios foi esvaziado. (Cruz, 2000). }\end{array}$ \\
\hline $\begin{array}{l}\text { Fundação de Assistência ao } \\
\text { Estudante/FAE }\end{array}$ & Lei 7.091, de abril de 1983. & $\begin{array}{l}\text { Apoiar secretarias de ensino do MEC e desenvolver os } \\
\text { programas de assistência ao estudante: Programa do Livro } \\
\text { Didático - Ensino fundamental/PLIDEF, Programa Nacional de } \\
\text { Alimentação Escolar/PNAE e outros. }\end{array}$ & $\begin{array}{l}\text { Dificuldades em distribuir os livros nos prazos, lobbies das } \\
\text { editoras, autoritarismo na distribuição de livros, proposta de } \\
\text { participação dos professores na escolha dos livros e ampliação } \\
\text { do Programa para as demais séries do ensino Fundamental } \\
\text { (Freitag, Motta e Costa, 1989). }\end{array}$ \\
\hline $\begin{array}{l}\text { Programa Nacional do livro } \\
\text { Didático/PNLD, a cargo da } \\
\text { FAE }\end{array}$ & $\begin{array}{l}\text { Decreto n. 9.154, } \begin{array}{r}\text { de } \\
\text { com }\end{array} \\
\text { 19/08/1985, } \\
\text { procedimentos estabelecidos } \\
\text { na Portaria FAE n. 863, de } \\
\text { 30/10/1985. }\end{array}$ & $\begin{array}{l}\text { Disponibilizar guias de livros didáticos para a indicação pelos } \\
\text { professores. Implantação de bancos de livros didáticos e } \\
\text { reutilização dos livros. Universalização do atendimento } \\
\text { inicialmente a todos os alunos de } 1^{\mathrm{a}} \text { e } 2^{\mathrm{a}} \text { séries e posteriormente } \\
\text { às oito séries do } 1^{\circ} \text { grau. }\end{array}$ & $\begin{array}{l}\text { Editoras com maior estrutura e melhores estratégias de } \\
\text { marketing conquistaram maior número de escolhas pelos } \\
\text { professores (Castro, 1996). }\end{array}$ \\
\hline PNLD & $\begin{array}{l}\text { Resolução n. 6, de 13/07/1993 } \\
\text { do FNDE. }\end{array}$ & $\begin{array}{l}\text { Vincular recursos para a aquisição dos livros didáticos do } \\
\text { PNLD. }\end{array}$ & $\begin{array}{l}\text { Estabeleceu fluxo regular de recursos para a aquisição e } \\
\text { distribuição de livros didáticos Editoras com maior estrutura e } \\
\text { melhores estratégias de marketing conquistaram maior número } \\
\text { de escolhas pelos professores (Castro, 1996). }\end{array}$ \\
\hline
\end{tabular}



elaborar catálogos com classificação para escolha pelos editoras. Ampliação progressiva de alocação de recursos, de responsabilidade do FNDE com extinção da FAE em fev. de 1997. 


\section{ANEXO 2 - SÍNTESE DA APRESENTAÇÃO DAS COLEÇÕES DIDÁTICAS DO COMPONENTE CURRICULAR HISTÓRIA NO GUIA DE LIVROS DIDÁTICOS - PNLD 2014}

\begin{tabular}{|c|c|c|c|c|}
\hline OBRA & ANO & AUTOR & EDITORA & TIPO DE ABORDAGEM DADA AO NEGRO E A ÁFRICA E LOCALIZAÇÃO \\
\hline Encontros com a história & PNLD/2014 & $\begin{array}{l}\text { Carla Maria J. } \\
\text { Anastasia } \\
\text { Maria Ribeiro }\end{array}$ & $\begin{array}{l}\text { Positivo/2012 - } 3^{\mathrm{a}} \\
\text { edição }\end{array}$ & $\begin{array}{l}\text { A obra possibilita a discussão de temas como racismo e preconceitos, entre outras temáticas } \\
\text { fundamentais. A história da África, dos afrodescendentes e das comunidades indígenas aparece em } \\
\text { todos os volumes, afirmando a diversidade étnica e cultural que permeia as experiências dessas } \\
\text { populações. Ressalta-se não apenas a diversidade, como também a riqueza cultural e histórica dos } \\
\text { povos africanos, dos afrodescendentes e dos povos indígenas. } 6^{\circ} \text { ano Povos do Oriente Antigo e da } \\
\text { África; } 7^{\circ} \text { ano Encontros de mundos diferentes; } 8^{\circ} \text { Ano Construção de um mundo novo; } 9^{\circ} \text { ano } \\
\text { Transformações para o século XX. }\end{array}$ \\
\hline $\begin{array}{l}\text { Estudar história: das origens } \\
\text { do homem à era digital }\end{array}$ & PNLD/2014 & Patrícia Ramos Braick & Moderna/2011 & 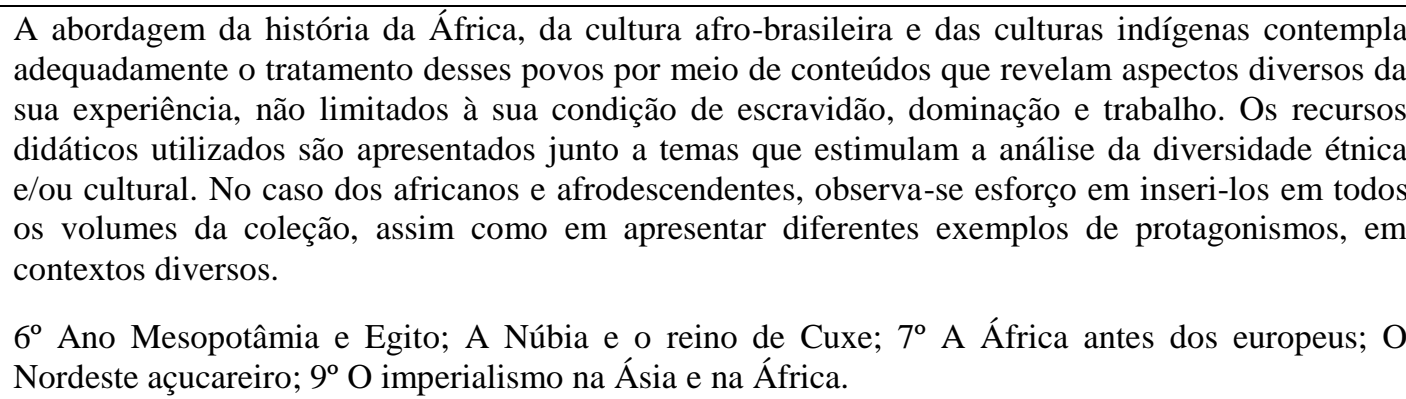 \\
\hline Link história & PNLD/2014 & $\begin{array}{l}\text { Denise Mattos Marino } \\
\text { Léo Stampacchio }\end{array}$ & $\begin{array}{l}\text { IBEP/2012 } \\
\text { edição }\end{array}$ & $\begin{array}{l}\text { A abordagem da coleção sobre a História da África, dos afrodescendentes e das comunidades } \\
\text { indígenas contempla a luta dos negros no Brasil, a cultura negra brasileira e o negro na formação da } \\
\text { sociedade nacional, assim como a contribuição desses povos nas áreas social, econômica e política } \\
\text { do país, porém está mais circunscrita aos períodos colonial e imperial da história do Brasil }-7^{\circ} \text { ano } \\
\text {-Trabalhadores: rebeldes e conquistadores. }\end{array}$ \\
\hline OBRA & ANO & AUTOR & EDITORA & TIPO DE ABORDAGEM DADA AO NEGRO E A ÁFRICA E LOCALIZAÇÃO \\
\hline $\begin{array}{lll}\text { HISTÓRIA } & \text { E } & \text { VIDA } \\
\text { INTEGRADA } & & \end{array}$ & PNLD/2014 & $\begin{array}{lr}\text { Nelson } & \text { Piletti } \\
\text { Claudino } & \text { Piletti } \\
\text { Thiago Tremonte de } \\
\text { Lemos }\end{array}$ & $\begin{array}{l}\text { Ática/2012 } \\
\text { edição }\end{array}$ & $\begin{array}{l}\text { A temática da história da África, das culturas afro-brasileira e indígena é abordada em todos os } \\
\text { volumes da coleção. Os conteúdos são tratados não apenas vinculados à escravidão como também } \\
\text { de forma autônoma, por exemplo, ao trabalhar um capítulo exclusivamente sobre a África. Vale } \\
\text { ressaltar que a abordagem da coleção sobre a história da África e dos africanos, a luta dos afro- } \\
\text { brasileiros no Brasil, a cultura africana e suas descendências na formação da cultura e da sociedade } \\
\text { brasileira busca identificar a contribuição desses povos nas áreas social, econômica e política, com } \\
\text { pertinência à história do Brasil. }\end{array}$ \\
\hline HISTÓRIA & PNLD/2014 & Joelza & FTD/2012 & $\begin{array}{l}\text { Em relação à história da África, podem ser encontrados diversos capítulos específicos ao longo da } \\
\text { coleção que a abordam, por exemplo: o Egito Antigo e os faraós negros, as antigas culturas nok e }\end{array}$ \\
\hline
\end{tabular}




\begin{tabular}{|c|c|c|c|c|}
\hline $\begin{array}{l}\text { DOCUMENTO IMAGEM } \\
\text { E TEXTO }\end{array}$ & & Domingues & $2^{\mathrm{a}}$ EDIÇÃO & $\begin{array}{l}\text { banto; os fenícios; o reino cristão de Axum; os reinos africanos sobre influência islâmica; os reinos } \\
\text { africanos tradicionais; a escravidão na África; o comércio de escravos; as relações com o Brasil no } \\
\text { século XViii; o imperialismo e as lutas contra o domínio europeu; as guerras e a segregação. } \\
\text { Quanto à cultura afro-brasileira, a coleção contempla conteúdos relacionados, por exemplo, com a } \\
\text { vida dos escravos no Brasil; as estratégias de resistência, a forma de organização familiar; os } \\
\text { aspectos culturais, as relaçães com a África no século XViii; o papel dos negros em eventos como a } \\
\text { Cabanagem, a Balaiada, a Revolta dos Malês e a sabinada; e o fim da escravidão. }\end{array}$ \\
\hline $\begin{array}{l}\text { HISTÓRIA NOS } \\
\text { DIAS DE HOJE }\end{array}$ & PNLD/2014 & $\begin{array}{l}\text { Flávio de Campos } \\
\text { Regina Claro } \\
\text { Miriam Dolhnikof }\end{array}$ & $\begin{array}{l}\text { Leya/2012 } \\
1^{\text {a edição }}\end{array}$ & $\begin{array}{l}\text { Constam orientações sobre o trabalho com história e cultura dos povos africanos em textos sobre } \\
\text { aspectos históricos e historiográficos africanos e sobre racismo. No Livro do Aluno, os textos a } \\
\text { respeito da história da África estão em capítulos específicos ou integrados aos temas gerais, que } \\
\text { tratam de economia, política, cultura e sociedade oferecendo um grande panorama da Antiguidade à } \\
\text { atualidade. } 6^{\circ} \text { Ano: A África de muitos povos, Volume } 1,7^{\circ} \text { Anos. A economia colonial e o tráfico } \\
\text { negreiro. A sociedade escravista colonial; Volume } 2 \text {. }\end{array}$ \\
\hline OBRA & ANO & AUTOR & EDITORA & TIPO DE ABORDAGEM DADA AO NEGRO E A ÁFRICA E LOCALIZAÇÃO \\
\hline $\begin{array}{l}\text { HISTÓRIA } \\
\text { SOCIEDADE \& } \\
\text { CIDADANIA }\end{array}$ & PNLD/2014 & Alfredo Boulos Júnior & $\begin{array}{l}\text { Editora FTD } \\
2^{\mathrm{a}} \text { edição } 2012\end{array}$ & $\begin{array}{l}\text { No tocante à inclusão da história da África e da cultura africana, afro-brasileira e indígena há, na } \\
\text { coleção, conteúdos, textos diversos e atividades que abordam predominantemente aspectos da } \\
\text { história política e cultural desses povos. Destacam-se os textos de apoio sobre a implementação } \\
\text { legal das referidas temáticas no ensino básico assim como as indicações de referências } \\
\text { bibliográficas sobre a historiografia da África. } 6^{\circ} \text { ano Vida urbana: Oriente e África; A luta por } \\
\text { direitos. } 7^{\circ} \text { ano: Diversidade e discriminação religiosa. } 8^{\circ} \text { ano: - Cultura e trabalho; A luta pela } \\
\text { cidadania; } \\
\text { Emancipação, terra e liberdade. } 9^{\circ} \text { ano: Dominação e resistência. }\end{array}$ \\
\hline $\begin{array}{l}\text { JORNADAS. } \\
\text { HISTÓRIA }\end{array}$ & PNLD/2014 & $\begin{array}{l}\text { Silvia Panazzo } \\
\text { Maria Luísa Albiero } \\
\text { Vaz }\end{array}$ & $\begin{array}{l}\text { Saraiva Livreiros } \\
\text { Editores } \\
2^{\text {a }} \text { edição } 2012\end{array}$ & $\begin{array}{l}\text { Em relação à História da África, da cultura afro-brasileira e das culturas indígenas, constam } \\
\text { conteúdos em todos os volumes da coleção, podendo ser citados, a título de exemplo: no } 6^{\circ} \text { ano, o } \\
\text { sedentarismo e a pré-história na África e na América, os egípcios e outros povos africanos; no } 7^{\circ} \\
\text { ano, a história dos povos indígenas e africanos nos séculos anteriores ao contato com os europeus, } \\
\text { as trocas culturais e as consequências dos contatos entre indígenas e europeus; no } 8^{\circ} \text { ano, o } \\
\text { apresamento dos indígenas pelos bandeirantes, a escravidão dos africanos na exploração das minas, } \\
\text { a Revolta dos Malês, a participação de afrodescendentes nas campanhas abolicionistas; no } 9^{\circ} \text { ano, o } \\
\text { imperialismo e a descolonização da África, os desafios desse continente na nova ordem mundial. } \\
\text { Pesar disso, persiste na coleção certa centralização narrativa no estudo da Europa e da América, o } \\
\text { que resulta em uma abordagem pouco atrelada ao exame das especificidades dos povos africanos e } \\
\text { indígenas no Brasil }\end{array}$ \\
\hline OBRA & ANO & AUTOR & EDITORA & TIPO DE ABORDAGEM DADA AO NEGRO E A ÁFRICA E LOCALIZAÇÃO \\
\hline $\begin{array}{l}\text { LEITURAS DA } \\
\text { HISTÓRIA }\end{array}$ & PNLD/2014 & Oldimar Cardoso & $\begin{array}{l}\text { Escala Educacional } \\
1^{\text {a }} \text { edição } 2012\end{array}$ & $\begin{array}{l}\text { Apresenta-se na coleção por meio da história da África, contemplada, por exemplo, no trabalho com } \\
\text { os reinos africanos do Norte e no sul do continente e na apresentação de contos e lendas africanas. } \\
\text { Explicita as formas de resistência à escravidão e trata sobre a importância dos quilombos. } \\
\text { Sucintamente, é trabalhada a situação dos afrodescendentes no país atualmente, discutindo questões } \\
\text { e políticas contemporâneas relativas à questão racial no Brasil acompanhada de reflexões acerca do }\end{array}$ \\
\hline
\end{tabular}




\begin{tabular}{|c|c|c|c|c|}
\hline & & & & $\begin{array}{l}\text { combate ao preconceito e das desigualdades sociais. Entretanto, esses sujeitos são tratados ainda na } \\
\text { relação com uma história eurocêntrica. } 6^{\circ} \text { ano: A Antiguidade na África, } 7^{\circ} \text { ano: África, Ásia. } 8^{\circ} \\
\text { ano: a Abolição da escravidão. }\end{array}$ \\
\hline $\begin{array}{lr}\text { NOVO } & \text { HISTÓRIA, } \\
\text { CONCEITOS } & \text { E } \\
\text { PROCEDIMENTOS }\end{array}$ & PNLD/2014 & $\begin{array}{l}\text { Ricardo Dreguer } \\
\text { Eliete Toledo }\end{array}$ & $\begin{array}{l}\text { Saraiva Livreiros } \\
\text { Editores } \\
3^{\text {a edição }} 2012\end{array}$ & $\begin{array}{l}\text { A história da África, abordada desde a Antiguidade até a contemporaneidade, contempla } \\
\text { importantes temas da história Política e das trocas culturais entre povos. Dá-se atenção às } \\
\text { resistências desses sujeitos e grupos frente aos processos de colonização ocorridos entre os séculos } \\
\text { XVI e XX. Privilegiam-se, também, as trocas culturais entre povos africanos e outros povos para } \\
\text { além do continente. O tratamento dado à história dos afro-brasileiros é destaque da coleção. } \\
\text { Reforça-se o papel ativo dos trabalhadores escravizados no processo abolicionista e dos afro- } \\
\text { brasileiros no pós-abolição. Questões atuais, como a luta por direitos travada pelos } \\
\text { afrodescendentes, são discutidas nas seções Diálogo com o presente, outras visões, Vida cotidiana e } \\
\text { para ampliar o conhecimento. } 5^{\circ} \text { ano: Âfrica, Ásia e América; } 7^{\circ} \text { ano: América: indígenas, africanos } \\
\text { e europeus. }\end{array}$ \\
\hline OBRA & ANO & AUTOR & EDITORA & TIPO DE ABORDAGEM DADA AO NEGRO E A ÁFRICA E LOCALIZAÇÃO \\
\hline $\begin{array}{ll}\text { PARA ENTENDER } & \text { A } \\
\text { HISTÓRIA } & \end{array}$ & PNLD/2014 & $\begin{array}{l}\text { João Tristan Vargas } \\
\text { Divalte } \quad \text { Garcia } \\
\text { Figueira }\end{array}$ & $\begin{array}{l}\text { Saraiva Livreiros } \\
\text { Editores } \\
4^{\text {a }} \text { edição } 2012\end{array}$ & $\begin{array}{l}\text { História da África, da cultura afro-brasileira e das culturas indígenas, observa-se que a coleção } \\
\text { articula essa temática à formação sociocultural do Brasil e da população brasileira. Esse esforço } \\
\text { contribui para promover o respeito e a valorização das culturas indígena e africana bem como a } \\
\text { compreensão do caráter multicultural da formação do Brasil. Há ainda textos e atividades que } \\
\text { buscam explorar diferentes relações e aspectos no tocante às questões sociais, culturais e } \\
\text { econômicas. Em se tratando do Brasil, o livro do aluno dimensiona a escravidão, a discriminação } \\
\text { como também as resistências e lutas dos diferentes grupos sociais e étnicos. } 6^{\circ} \text { ano: As múltiplas } \\
\text { civilizações africanas; } 7^{\circ} \text { ano: Açúcar e escravidão no Brasil colonial. }\end{array}$ \\
\hline $\begin{array}{l}\text { PARA VIVER } \\
\text { JUNTOS } \\
\text { HISTÓRIA }\end{array}$ & PNLD/2014 & $\begin{array}{l}\text { Muryatan Santana } \\
\text { Barbosa } \\
\text { Débora } \\
\text { Motooka } \\
\text { Anderson } \\
\text { Reis } \\
\text { Ana Loberti dos } \\
\text { Anicia Lana Nemi }\end{array}$ & 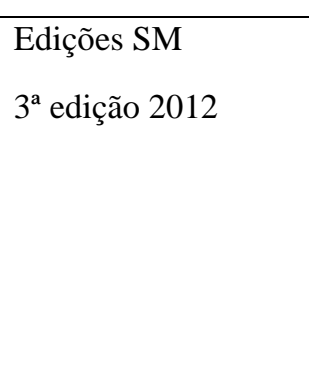 & $\begin{array}{l}\text { A história dos afrodescendentes no Brasil começa com a experiência da escravidão, no período } \\
\text { colonial. Aborda-se o contexto do continente africano anterior à prática do tráfico de escravos pelos } \\
\text { portugueses, tratando também das condições da viagem nos navios negreiros e das atividades rurais } \\
\text { e urbanas as quais os negros eram submetidos. Também apresenta as formas de resistência à } \\
\text { escravidão, a constituição dos quilombos e as lutas e os direitos dos remanescentes quilombolas, } \\
\text { além de destacar suas contribuições para a cultura brasileira. Há, inclusive, quantidade expressiva } \\
\text { de imagens de afrodescendentes, principalmente associados à experiência da escravidão. Sua } \\
\text { presença na atualidade é destacada em figuras como a do jogador de futebol a ou do sambista. } 6^{\circ} \\
\text { ano: Á África; } 7^{\circ} \text { ano A África e os africanos no Brasil. }\end{array}$ \\
\hline $\begin{array}{l}\text { PERSPECTIVA } \\
\text { HISTÓRIA }\end{array}$ & PNLD/2014 & $\begin{array}{l}\text { Renato Mocellin } \\
\text { Rosiane de Camargo }\end{array}$ & $\begin{array}{l}\text { Editora do Brasil } \\
2^{\mathrm{a}} \text { edição } 2012\end{array}$ & $\begin{array}{l}\text { A história da África e da cultura afro-brasileira são tratadas de forma bem equilibrada, ao longo da } \\
\text { obra, em seus quatro volumes. O continente africano é abordado antes, durante e depois do tráfico } \\
\text { atlântico. No caso dos afro-brasileiros, o impacto da escravidão é significativo na construção da } \\
\text { narrativa do Livro do Aluno. Há uma abordagem que privilegia a análise da importância da mão de } \\
\text { obra escrava na produção econômica dos períodos colonial e imperial. } 7^{\circ} \text { ano: Culturas da Ásia, } \\
\text { África e América. }\end{array}$ \\
\hline
\end{tabular}




\begin{tabular}{|c|c|c|c|c|}
\hline OBRA & ANO & AUTOR & EDITORA & TIPO DE ABORDAGEM DADA AO NEGRO E A ÁFRICA E LOCALIZAÇÃO \\
\hline $\begin{array}{l}\text { POR DENTRO DA } \\
\text { HISTÓRIA }\end{array}$ & PNLD/2014 & $\begin{array}{l}\text { Maria Aparecida } \\
\text { Pontes } \\
\text { Célia Cerqueira } \\
\text { Pedro Santiago }\end{array}$ & 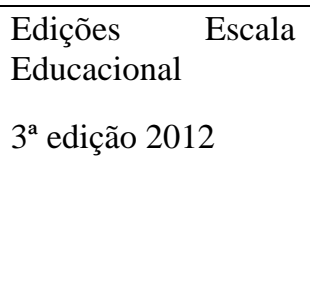 & $\begin{array}{l}\text { História da África, da cultura afro-brasileira e das culturas indígenas encontram-se bem distribuídos } \\
\text { nos quatro volumes por meio de capítulos, em imagens, atividades, boxes e seções. Os temas são } \\
\text { tratados de modo plural, não estando restritos ao período colonial ou imperial, incluindo também a } \\
\text { experiência contemporânea desses sujeitos. Há, também, incentivos variados que promovem a } \\
\text { reflexão sobre a tolerância religiosa, a importância de se respeitar as diferenças e, ainda, sobre as } \\
\text { relações de desigualdade. Nessa direção, observam-se diferentes atividades em que serna possível } \\
\text { discutir acerca de conflitos, discriminação e preconceito bem como de lutas e injustiça social. }\end{array}$ \\
\hline $\begin{array}{l}\text { PROJETO ARARIBÁ } \\
\text { HISTÓRIA }\end{array}$ & PNLD/2014 & $\begin{array}{ll}\text { Maria } & \text { Raquel } \\
\text { Apolinário } & \end{array}$ & $\begin{array}{l}\text { Editora Moderna } \\
3^{\text {a }} \text { edição } 2010\end{array}$ & $\begin{array}{l}\text { A coleção contempla elementos sobre a história da África, da cultura afro-brasileira e das culturas } \\
\text { indígenas. Há uma valorização da cultura africana, promovendo o respeito à diversidade e às } \\
\text { experiências históricas de seus povos. A história dos afro-brasileiros contempla a experiência da } \\
\text { escravidão: da situação dos povos escravizados antes da inserção dos europeus em seus territórios } \\
\text { até os trabalhos a que eram submetidos, no campo e nas cidades; nas formas de resistência à } \\
\text { escravidão, com o intuito de incorporar a renovada historiografia sobre a história da escravidão no } \\
\text { Brasil, concebendo os escravizados como sujeitos ativos, destacando as estratégias ligadas aos } \\
\text { quilombos. Há uma perspectiva que confere uma valorização da cultura afrodescendente como } \\
\text { integrante e contribuinte da cultura brasileira. }\end{array}$ \\
\hline $\begin{array}{l}\text { PROJETO RADIX - } \\
\text { HISTÓRIA }\end{array}$ & PNLD/2014 & Cláudio Vicentino & $\begin{array}{l}\text { Editora Scipione } \\
2^{\text {a }} \text { edição } 2012\end{array}$ & $\begin{array}{l}\text { A história da África encontra-se articulada ao processo histórico europeu, havendo um módulo } \\
\text { dedicado aos povos africanos e seus reinos desde os primeiros humanos até o tráfico de escravos. A } \\
\text { África é tratada também a partir do processo de descolonização e na temática que aborda o } \\
\text { apartheid. A escravidão é trabalhada como parte da história africana. A história dos africanos volta } \\
\text { a ser discutida nos módulos dedicados à história do Brasil. } 7^{\circ} \text { ano: África: dos primeiros humanos } \\
\text { ao tráfico de escraos. }\end{array}$ \\
\hline OBRA & ANO & AUTOR & EDITORA & TIPO DE ABORDAGEM DADA AO NEGRO E A ÁFRICA E LOCALIZAÇÃO \\
\hline $\begin{array}{ll}\text { PROJETO } & \text { TELÁRIS } \\
\text { HISTÓRIA } & \\
\end{array}$ & PNLD/2014 & $\begin{array}{lr}\text { Reinaldo } & \text { Seriacopi } \\
\text { Gislane Campos A. } \\
\text { Seriacopi }\end{array}$ & $\begin{array}{l}\text { Ática } 1^{a} \text { edição } \\
2012\end{array}$ & $\begin{array}{l}\text { A história da África e da cultura afro-brasileira é expressa na coleção pelo tratamento das } \\
\text { civilizações e diversidades dos povos africanos na África e na América, bem como pela evidência } \\
\text { de sua participação e resistência à exploração no meio da escravidão e exploração colonial. A } \\
\text { visibilidade dos africanos e afrodescendentes é uniforme na coleção como um todo, com ênfase } \\
\text { maior no volume do } 7^{\circ} \text { ano. Membros de comunidades africanas e afro-brasileiras aparecem na } \\
\text { coleção como agentes da história desde o mundo antigo até depois do período da descolonização } \\
\text { afro-asiática. Trabalha também a valorização afro-brasileira por meio das discussões sobre seu } \\
\text { passado histórico, da questão dos remanescentes de quilombos, do Teatro Experimental do Negro, } \\
\text { dos movimentos negros brasileiros e de outros expedientes que evidenciam o negro como sujeito da } \\
\text { história. Nesse sentido, é positivo o recurso às lutas africanas pela independência, o pan-africanismo } \\
\text { e a menção aos vários exemplos positivos de sujeitos afrodescendentes em posiçães sociais de } \\
\text { destaque. }\end{array}$ \\
\hline
\end{tabular}




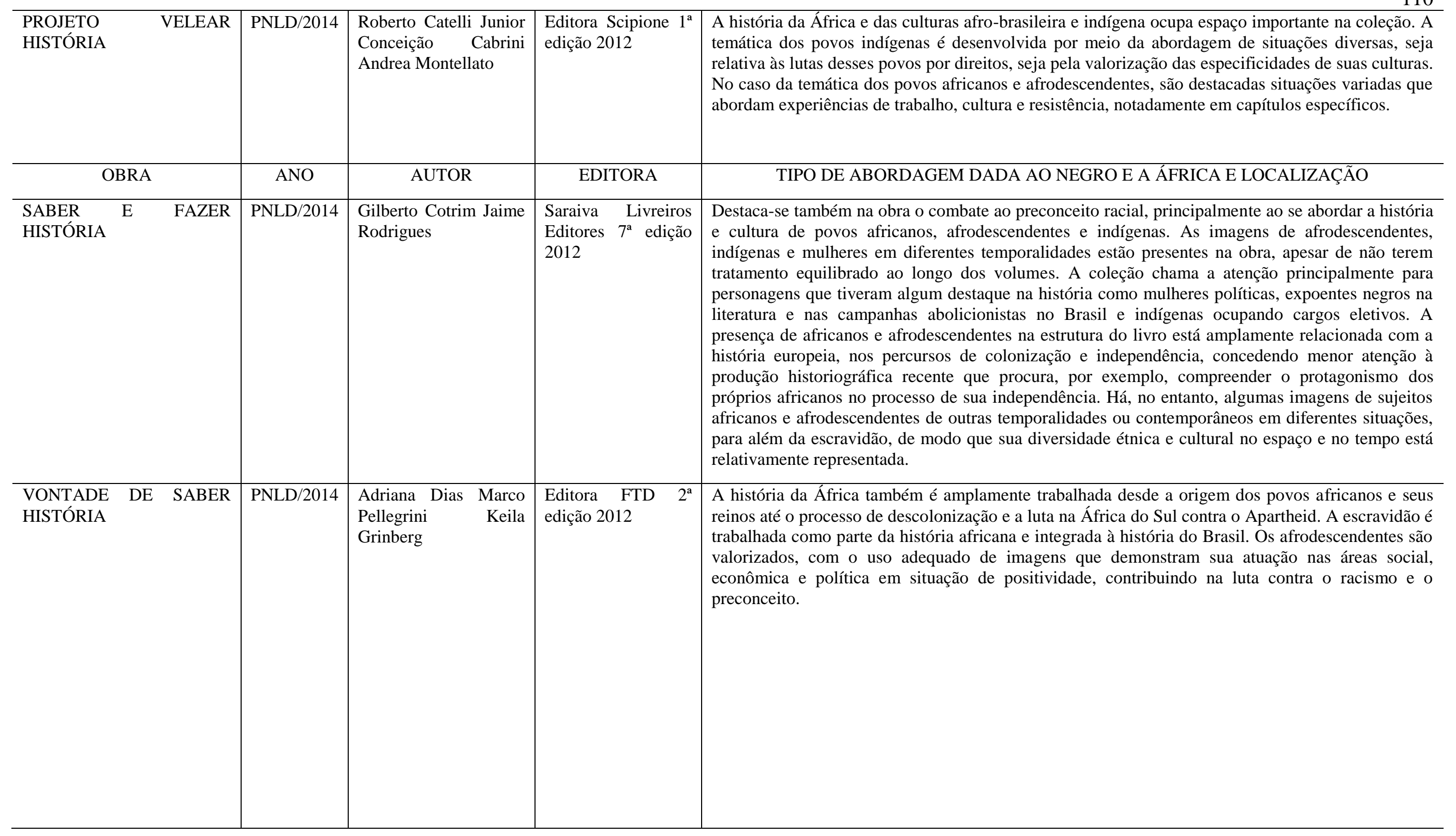

(BRASIL Guia Nacional do Livro Didático, 2014). 
ANEXO 3 - SÍNTESE DOS TÍTULOS PUBLICADOS PELAS EDITORAS: ÁTICA, MODERNA E SCIPIONE, A PARTIR DO ANO DE 2003, COM TEMÁTICAS RELACIONADAS A CULTURA AFRICANA NO SEGUIMENTO DIDÁTICO, PARADIDÁTICO E DE LITERATURA INFANTIL E LITERATURA INFANTO - JUVENIL.

\begin{tabular}{|c|c|c|c|c|c|}
\hline TÍTULO & EDITORA/ SEGUIMENTO & AUTOR & ANO & TEMÁTICAS & SINÓPSE \\
\hline $\begin{array}{l}\text { "Nós" do Brasil } \\
\text { Estudo das } \\
\text { Relações Étnico- } \\
\text { Raciais }\end{array}$ & $\begin{array}{l}\text { Editora: Moderna } \\
\text { Coleção Polêmica } \\
\text { Segmento: Literatura Juvenil } \\
\text { Ano Escolar: } 1^{\circ} \text { Ano (EM), } \\
2^{\circ} \text { Ano (EM), } 3^{\circ} \text { Ano (EM) } \\
\text { ISBN: } 9788516082529 \\
\text { Edição: } 1\end{array}$ & Rosiane Rodrigues & 2016 & $\begin{array}{l}\text { África, africanos, etnias, indígenas, } \\
\text { judeus, muçulmanos, raças, relações } \\
\text { raciais/ étnicas. }\end{array}$ & $\begin{array}{l}\text { Com um estilo leve, agradável, instigante, do início ao } \\
\text { fim, nós do Brasil não se contenta em ficar na superfície } \\
\text { dos temas. Vai fundo! Fala de integridade negra, } \\
\text { identidade africana, identidade indígena. Fala de } \\
\text { ciganos, de judeus, de muçulmanos, das diversas } \\
\text { Áfricas que existem dentro da África, suas diferenças } \\
\text { culturais, povos e religiões, e fala do Brasil. } \\
\text { Este livro nos proporciona viagens, que possibilitam } \\
\text { conexões históricas importantes para a compreensão de } \\
\text { quem somos } \\
\text { Ele nos mostra que há saídas, sim, para a aplicação da } \\
\text { temática das Relações Raciais sem incorrer em dogmas, } \\
\text { estereótipos ou folclorizações. }\end{array}$ \\
\hline $\begin{array}{lr}\text { África - } & \text { Terra, } \\
\text { sociedades } & \text { e } \\
\text { conflitos. } & \end{array}$ & $\begin{array}{l}\text { Editora: Moderna } \\
\text { Coleção Polêmica } \\
\text { Série Escolar: } 1^{\circ} \text { Ano (EM), } \\
2^{\circ} \text { Ano (EM), } 3^{\circ} \text { Ano (EM) } \\
\text { Segmento: Literatura Juvenil } \\
\text { ISBN: } 9788516077747 \\
\text { Edição: } 2\end{array}$ & $\begin{array}{l}\text { Nelson Bacic Olic, Beatriz } \\
\text { Canepa }\end{array}$ & 2016 & $\begin{array}{l}\text { Aids, Conflitos étnicos, Conflitos } \\
\text { políticos, Conflitos } \\
\text { População africana, Riqueza natural }\end{array}$ & $\begin{array}{l}\text { A África, até recentemente, ficou à margem do processo } \\
\text { de globalização e se mostrou para o mundo apenas pelos } \\
\text { seus enormes problemas socioeconômico e pelas } \\
\text { tragédias decorrentes de seus conflitos. Fatos recentes } \\
\text { têm sinalizado, ainda que timidamente, que algo está } \\
\text { mudando para melhor. } \\
\text { Neste livro, em sua } 2^{\text {a }} \text { edição, revista e atualizada, o } \\
\text { leitor encontrará um conjunto de informações e análises } \\
\text { cuja intenção é contribuir para um melhor conhecimento } \\
\text { das realidades africanas atuais. }\end{array}$ \\
\hline TÍTULO & EDITORA/ SEGUIMENTO & AUTOR & ANO & TEMÁTICAS & SINÓPSE \\
\hline Arte africana & $\begin{array}{l}\text { Editora: Moderna } \\
\text { Coleção Artistas anônimos } \\
\text { Série Escolar: 6 }{ }^{\circ} \text { Ano (EF2), } \\
7^{\circ} \text { Ano (EF2), } 8^{\circ} \text { Ano (EF2), } \\
9^{\circ} \text { Ano (EF2) } \\
\text { Segmento: Literatura Infanto }\end{array}$ & Hildegard Feist & 2010 & Pluralidade Cultural. & $\begin{array}{l}\text { Neste livro, apresentamos a arte africana, expressão que } \\
\text { os estudiosos ocidentais encontraram para englobar toda } \\
\text { a produção artística tradicional das centenas de povos } \\
\text { que vivem nas dezenas de países da África negra. Não } \\
\text { teríamos como mostrar a arte de tantos povos, com } \\
\text { culturas, línguas, dialetos e religiões diferentes em um } \\
\text { só livro. Por isso, selecionamos alguns exemplos de arte } \\
\text { que nos pareceram mais interessantes, mais bonitos, } \\
\text { mais significativos em materiais tão diversos como }\end{array}$ \\
\hline
\end{tabular}




\begin{tabular}{|c|c|c|c|c|c|}
\hline & $\begin{array}{l}\text { Juvenil } \\
\text { ISBN: } 9788516066925 \\
\text { Edição: } 1\end{array}$ & & & & argila, metal e madeira. \\
\hline Bia na África & $\begin{array}{l}\text { Editora: Moderna } \\
\text { Coleção : viagens de Bia } \\
\text { Série Escolar : } 3^{\circ} \text { Ano (EF1), } \\
4^{\circ} \text { Ano (EF1), 5º Ano (EF1) } \\
\text { Segmento: Literatura Infanto } \\
\text { Juvenil } \\
\text { ISBN: } 9788516102715 \\
\text { Edição: } 1\end{array}$ & Ricardo Dreguer & 2007 & $\begin{array}{l}\text { Influências culturais africanas no Brasil, } \\
\text { Angola: Origens e costumes de nossos } \\
\text { antepassados, que vieram escravizados } \\
\text { para o Brasil, Egito: Pirâmides, múmias e } \\
\text { a influência árabe, Quênia: Das cidades à } \\
\text { reserva de Masai Mara, Visita ao Sudão, } \\
\text { Mali, Congo e Zimbábue. }\end{array}$ & $\begin{array}{l}\text { Bia é filha de uma diplomata e viaja com a mãe por } \\
\text { diferentes partes do mundo: África, Europa, Ásia... } \\
\text { Nessas viagens ela conhece muitas das influências que } \\
\text { outros países trouxeram para o Brasil. } \\
\text { Prepare suas malas e viaje com a Bia para a África. } \\
\text { Conheça o Egito e o Quênia e more com ela em Angola! } \\
\text { Lá você encontrará muitas das raízes do brasil e dos } \\
\text { brasileiros. Boa Viagem! }\end{array}$ \\
\hline TÍTULO & EDITORA/ SEGUIMENTO & AUTOR & ANO & TEMÁTICAS & SINÓPSE \\
\hline $\begin{array}{l}\text { Com os pés na } \\
\text { África }\end{array}$ & $\begin{array}{l}\text { Editora: Moderna } \\
\text { Série Giro } \\
\text { Série escolar: } 8^{\circ} \text { Ano (EF2), } \\
9^{\circ} \text { Ano (EF2) } \\
\text { Segmento: Literatura Infanto } \\
\text { Juvenil } \\
\text { ISBN: } 9788516102463 \\
\text { Edição: } 1\end{array}$ & Sérgio Túlio Caldas & 2016 & $\begin{array}{l}\text { África, Angola, Cultura e tradições, Diário } \\
\text { de viagem, Marrocos. }\end{array}$ & $\begin{array}{l}\text { Depois de ganhar o grande prêmio em um programa de } \\
\text { quiz da televisão, o jovem Túlio joga a mochila nas } \\
\text { costas e parte para ver o mundo. O primeiro destino é a } \\
\text { África. Em uma terra desconhecida, ele passa por } \\
\text { perrengues, faz descobertas, encara riscos e encontra } \\
\text { pessoas com valores diferentes dos seus. Enquanto } \\
\text { viaja, vai aprendendo sobre história, geografia, natureza } \\
\text { e a cultura das regiões que visita. Nessa jornada, o } \\
\text { personagem se torna uma importante testemunha dos } \\
\text { nossos tempos. }\end{array}$ \\
\hline
\end{tabular}




\begin{tabular}{|c|c|c|c|c|c|}
\hline Cordel África & $\begin{array}{l}\text { Editora: Moderna } \\
\text { Coleção Saber em Cordel } \\
\text { Série Escolar: } 2^{\circ} \text { Ano (EF1), } \\
3^{\circ} \text { Ano (EF1), } 4^{\circ} \text { Ano (EF1), } \\
5^{\circ} \text { Ano (EF1), } 6^{\circ} \text { Ano (EF2) } \\
\text { Segmento: Literatura Infanto } \\
\text { Juvenil } \\
\text { ISBN: } 9788516092399 \\
\text { Edição: } 1\end{array}$ & César Obeid & 2014 & $\begin{array}{l}\text { Cultura africana, danças e músicas do } \\
\text { Brasil, herança africana na língua, história } \\
\text { da invasão da África e da escravidão, } \\
\text { influência africana em ritmos, literatura de } \\
\text { cordel. }\end{array}$ & $\begin{array}{l}\text { O livro propõe uma visita, por meio da literatura de } \\
\text { cordel, às diversas culturas que atravessaram o Atlântico } \\
\text { - vindas do distante continente africano -, se fundiram } \\
\text { em solo brasileiro e tomaram dimensões próprias. A } \\
\text { consciência da enorme influência dessas culturas no } \\
\text { cotidiano de todos os brasileiros ajudará na tentativa de } \\
\text { acabar com os preconceitos que até hoje, infelizmente, } \\
\text { assombram a nossa sociedade. Para ilustrar toda essa } \\
\text { riqueza de detalhes em forma de rimas, foi escolhida } \\
\text { uma técnica de ilustrações digitais baseada na } \\
\text { xilogravura. }\end{array}$ \\
\hline TÍTULO & EDITORA/ SEGUIMENTO & AUTOR & ANO & TEMÁTICAS & SINÓPSE \\
\hline $\begin{array}{l}\text { Da cor da } \\
\text { esperança } \\
\text { A libertação dos } \\
\text { escravos }\end{array}$ & $\begin{array}{l}\text { Editora: Moderna } \\
\text { Série recontando a História } \\
\text { Série Escolar: } 6^{\circ} \text { Ano (EF2), } \\
7^{\circ} \text { Ano (EF2), } 8^{\circ} \text { Ano (EF2), } \\
9^{\circ} \text { Ano (EF2) } \\
\text { Segmento: Literatura Infanto } \\
\text { Juvenil } \\
\text { ISBN: } 9788516102746 \\
\text { Edição } 1\end{array}$ & Márcia Abreu & 2016 & $\begin{array}{l}\text { Abolicionismo, Caifazes, Escravidão, Lei } \\
\text { Áurea. }\end{array}$ & $\begin{array}{l}\text { Que cor deve ter alguém para ser gente? De que cor } \\
\text { deve ser para ter esperança? Até o século XIX, muitos } \\
\text { negros foram escravizados e tratados como animais ou } \\
\text { coisas. Eram comprados e vendidos, trabalhavam à } \\
\text { força, eram castigados duramente. Gente não se } \\
\text { submete a este tipo de tratamento sem revolta, por isso } \\
\text { eles organizaram rebeliões e fugas, resistiram aos } \\
\text { desmandos e lutaram para se tornar livres. Da cor da } \\
\text { esperança conta a história de um grupo de negros - } \\
\text { escravos, livres e libertos - desde a captura na África } \\
\text { até os movimentos abolicionistas. Gente que tinha dor e } \\
\text { queria ser livre, gente que sofria e fazia festa, gente que } \\
\text { amava e sentia medo. }\end{array}$ \\
\hline
\end{tabular}




\begin{tabular}{|c|c|c|c|c|c|}
\hline $\begin{array}{l}\text { Kiese: História } \\
\text { de um africano } \\
\text { no Brasil }\end{array}$ & $\begin{array}{l}\text { Editora: Moderna } \\
\text { Coleção Antepassados } \\
\text { Série Escolar: } 4^{\circ} \text { Ano (EF1), } \\
5^{\circ} \text { Ano (EF1), } 6^{\circ} \text { Ano (EF2) } \\
\text { Segmento: Literatura Infanto } \\
\text { Juvenil } \\
\text { ISBN: } 9788516096700 \\
\text { Edição: } 1^{a} \text { Edição }\end{array}$ & Ricardo Dreguer & 2016 & $\begin{array}{l}\text { África, Cultura afro-brasileira, Escravidão } \\
\text { no Brasil. }\end{array}$ & $\begin{array}{l}\text { O livro narra a trajetória de Kiese, um menino que foi } \\
\text { capturado ainda na infância em sua aldeia, na África, e } \\
\text { trazido para o Brasil para ser escravizado. É também a } \\
\text { história de muitos africanos que foram tirados de seu } \\
\text { território, separados de seus familiares e amigos e } \\
\text { trazidos para o Brasil ao longo do tempo que durou o } \\
\text { regime escravista em nosso país. A história de Kiese é a } \\
\text { história de um brasileiro que lutou para conquistar um } \\
\text { lugar para ser feliz com sua família, seus amigos e sua } \\
\text { gente. Sua história se confunde com a própria formação } \\
\text { do Brasil. }\end{array}$ \\
\hline TÍTULO & EDITORA/ SEGUIMENTO & AUTOR & ANO & TEMÁTICAS & SINÓPSE \\
\hline Moçambique & $\begin{array}{l}\text { Editora: Moderna } \\
\text { Autor: Júlio Emílio Braz } \\
\text { Segmento escolar } 7^{\circ} \text { Ano } \\
\text { (EF2), } 8^{\circ} \text { Ano (EF2), } 1^{\circ} \text { Ano } \\
(\mathrm{EM}), 2^{\circ} \text { Ano (EM), } 3^{\circ} \text { Ano } \\
\text { (EM) } \\
\text { Segmento: Literatura Juvenil } \\
\text { ISBN: } 978851607072\end{array}$ & Júlio Emílio Braz & 2016 & História, Cultura, África e Angola. & $\begin{array}{l}\text { Desde criança sou apaixonado pelo saber, conhecer, } \\
\text { descobrir. Tenho uma necessidade quase orgânica de } \\
\text { conhecer e saber sobre tudo e qualquer coisa. } \\
\text { Moçambique fez parte durante muito tempo de um de } \\
\text { meus maiores interesses: a África como um todo e a } \\
\text { África que fala português, em particular. Natural olhar } \\
\text { para os países africanos que partilham conosco o } \\
\text { português e todo o Oceano Atlântico: Angola, Cabo } \\
\text { Verde, entre outros. Mas, e Moçambique? Esse grande } \\
\text { país fica do outro lado do continente africano e talvez } \\
\text { isso explique o fascínio que sempre despertou em mim. } \\
\text { Esse livro de contos e lendas é apenas o começo de sua } \\
\text { descoberta. Espero que vocês gostem de lê-lo tanto } \\
\text { quanto eu gostei de escrevê-lo. Júlio Emilio Braz }\end{array}$ \\
\hline $\begin{array}{ll}\text { Navegando pela } \\
\text { língua } \\
\text { portuguesa }\end{array}$ & $\begin{array}{l}\text { Editora: Moderna } \\
\text { Série Navegando } \\
\text { Série Escolar: } 2^{\circ} \text { Ano (EF1), } \\
3^{\circ} \text { Ano (EF1), } 4^{\circ} \text { Ano (EF1) }\end{array}$ & Douglas Tufano & 2007 & Pluralidade Cultural & $\begin{array}{l}\text { Nós conversamos, pensamos cantamos, escrevemos e } \\
\text { até sonhamos em português, afinal essa é a nossa língua. } \\
\text { Se viajarmos pelo imenso território brasileiro, } \\
\text { poderemos ouvir diferentes sotaques e até mesmo } \\
\text { algumas palavras que não conhecemos. Mesmo assim } \\
\text { conseguiremos entender o que brasileiros de outras } \\
\text { regiões dizem apesar dessa variedade de jeitos de falar, } \\
\text { todos no Brasil falam uma mesma língua. E você sabe }\end{array}$ \\
\hline
\end{tabular}




\begin{tabular}{|c|c|c|c|c|c|}
\hline & $\begin{array}{l}\text { Seguimento: Literatura } \\
\text { Infantil } \\
\text { ISBN: } 9788516054694 \\
\text { Edição: } 1\end{array}$ & & & & $\begin{array}{l}\text { como ela surgiu? Ela nasceu lá em Portugal e foi se } \\
\text { transformando no Brasil pela valiosa contribuição dos } \\
\text { índios, africanos e imigrantes. Vamos navegar e } \\
\text { conhecer um pouco mais dessa história? }\end{array}$ \\
\hline TÍTULO & EDITORA/ SEGUIMENTO & AUTOR & ANO & TEMÁTICAS & SINÓPSE \\
\hline $\begin{array}{l}\mathrm{O} \text { homem- } \\
\text { pássaro } \\
\text { História de um } \\
\text { migrante }\end{array}$ & $\begin{array}{l}\text { Editora: Moderna } \\
\text { Coleção Antepassados } \\
\text { Série Escolar: } 4^{\circ} \text { Ano (EF1), } \\
5^{\circ} \text { Ano (EF1), } 6^{\circ} \text { Ano (EF2) } \\
\text { Seguimento: Infanto-Juvenil } \\
\text { ISBN: 9788516093440 } \\
\text { Edição: 2a Edição }\end{array}$ & Ricardo Dreguer & 2014 & $\begin{array}{l}\text { Dificuldades nas cidades grandes, } \\
\text { diversidade de cultural, Migração. }\end{array}$ & $\begin{array}{l}\text { O livro conta a trajetória do menino Pedro desde as } \\
\text { origens de seus antepassados indígenas e africanos. O } \\
\text { foco principal da narrativa é sua migração da região do } \\
\text { Cariri, no Ceará, nos anos 1950, para São Paulo, Paraná, } \\
\text { Brasília e Amazonas nas décadas seguintes. Entre as } \\
\text { duas pontas de sua história estão relatos de seu modo de } \\
\text { vida no Ceará, os motivos da migração, as dificuldades } \\
\text { da viagem, os sofrimentos e as alegrias nos locais onde } \\
\text { se estabeleceu, desânimo e esperança, derrotas e } \\
\text { conquistas. Ingredientes que fazem parte da vida de } \\
\text { todos os brasileiros que um dia partiram em busca de } \\
\text { um canto em que pudessem ser felizes }\end{array}$ \\
\hline
\end{tabular}




\begin{tabular}{|c|c|c|c|c|c|}
\hline TÍTULO & EDITORA/ SEGUIMENTO & AUTOR & ANO & TEMÁTICAS & SINÓPSE \\
\hline $\begin{array}{l}\mathrm{O} \text { que há de } \\
\text { África em nós }\end{array}$ & $\begin{array}{l}\text { Editora: Moderna } \\
\text { Coleção Viramundo } \\
\text { Série escolar: } 4^{\circ} \text { Ano (EF1) } \\
\text { Seguimento: Literatura } \\
\text { Infantil } \\
\text { ISBN: } 9788516084769 \\
\text { Edição } 1\end{array}$ & $\begin{array}{l}\text { Wlamyra R. de Albuquerque, } \\
\text { Walter Fraga }\end{array}$ & 2009 & Africanos, escravidão, negros no Brasil. & $\begin{array}{l}\text { O que há de África em nós é um livro de viagens. Os } \\
\text { personagens atravessam o oceano Atlântico, visitam } \\
\text { outros períodos históricos, embarcam em navios e } \\
\text { chegam a lugares e situações diferentes. Cecília, } \\
\text { Camila, Akin, Chico, Isabel e Alice são alguns dos } \\
\text { viajantes a nos guiar nessa incrível história sobre a } \\
\text { presença africana no no prasil. } \\
\text { Tudo começa com uma pergunta: Desde quando o } \\
\text { mundo é mundo? Essa questão nos leva ao continente } \\
\text { africano. As invenções dos primeiros grupos humanos } \\
\text { que ali habitavam, a colonização portuguesa, a } \\
\text { escravidão, as relações entre o Brasil e os países } \\
\text { africanos e as criações culturais de africanos e seus } \\
\text { descendentes em nosso país são alguns dos pontos de } \\
\text { embarque rumo ao conhecimento sobre nossa história. } \\
\text { As rotas? É você quem faz. Experimente ler a partir de } \\
\text { qualquer capítulo, misture os personagens, refaça as } \\
\text { histórias que, afinal, também são suas. Mas venha logo, } \\
\text { o embarque já está garantido a quem tiver imaginação e } \\
\text { curiosidade. }\end{array}$ \\
\hline TÍTULO & EDITORA/ SEGUIMENTO & AUTOR & ANO & TEMÁTICAS & SINÓPSE \\
\hline $\begin{array}{l}\text { Papo de café } \\
\text { Conversando } \\
\text { sobre relações } \\
\text { internacionais }\end{array}$ & $\begin{array}{l}\text { Editora Moderna } \\
\text { Coleção Polêmica } \\
\text { Série Escolar: } 1^{\circ} \text { Ano (EM), } \\
2^{\circ} \text { Ano (EM), } 3^{\circ} \text { Ano (EM) } \\
\text { Seguimento Infantil } \\
\text { ISBN: } 9788516102456 \\
\text { Edição: } 1^{a} \text { Edição }\end{array}$ & Gilberto M. A. Rodrigues & 2016 & Geopolítica, Relações internacionais. & $\begin{array}{l}\text { O livro traz uma seleção de artigos publicados pelo } \\
\text { autor na mídia no período de } 2011 \text { a } 2015 \text {, adaptados e } \\
\text { atualizados. Os temas - assuntos internacionais que } \\
\text { ganharam destaque nos noticiários - foram organizados } \\
\text { em regiões: América Latina, África, Oriente Médio e } \\
\text { países árabes, Ásia, EUA e Europa. Além deles, o autor } \\
\text { abordou outros três tópicos: A ONU e suas agendas, } \\
\text { Ciência, Tecnologia \& Política e Esporte e Relações } \\
\text { Internacionais. }\end{array}$ \\
\hline Um $\quad$ grito $\mathrm{de}$ & Editora Moderna & Álvaro Cardoso Gomes, & 2016 & Escravidão, $\quad$ Palmares, & Um jovem escravo, batizado como Francisco, vive em \\
\hline
\end{tabular}




\begin{tabular}{|c|c|c|c|c|c|}
\hline 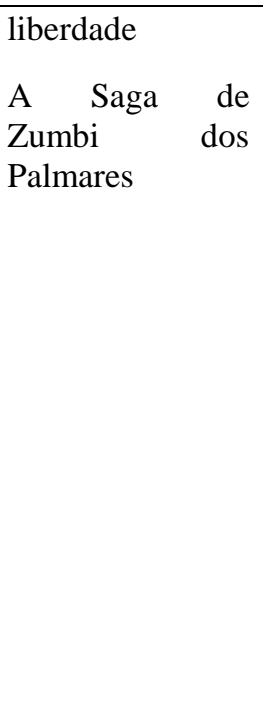 & 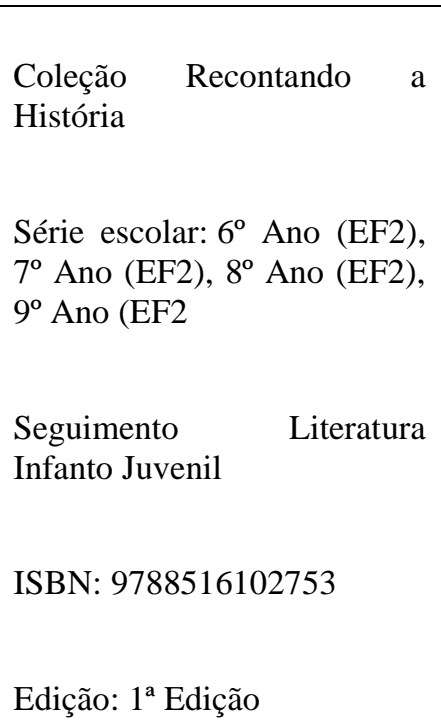 & Rafael Lopes de Sousa & & Sociedade Açucareira, Zumbi. & $\begin{array}{l}\text { companhia de um padre que é seu protetor. Aprendeu a } \\
\text { ler, a escrever e tem regalias que seus companheiros não } \\
\text { têm. Mesmo assim, é um eterno descontente, porque } \\
\text { almeja conquistar o bem que considera mais precioso - } \\
\text { a liberdade. Isso faz com que ele fuja em busca do reino } \\
\text { dos negros, em Palmares, que, sob o comando de } \\
\text { Ganga-Zumba, acolhe negros fugidos. Perseguido como } \\
\text { uma fera por caçadores de escravos, terá que mostrar } \\
\text { toda sua coragem para conseguir o que deseja. Ao } \\
\text { mesmo tempo, a história contempla também o drama da } \\
\text { jovem Kênia, uma escrava recém-chegada da África e } \\
\text { que se apaixonará por um forte guerreiro chamado } \\
\text { Vemba. Contando com muita ação, lutas sangrentas, } \\
\text { atos de heroísmo, a narrativa procura resgatar a saga de } \\
\text { Palmares. No reino criado pelos negros, estes } \\
\text { personagens farão de tudo para manter acesa a chama da } \\
\text { liberdade. }\end{array}$ \\
\hline $\begin{array}{l}\text { A Sabedoria de } \\
\text { Madi, o viajante } \\
\text { tolo }\end{array}$ & $\begin{array}{l}\text { Editora: Scipione } \\
\text { Coleção: Sabedoria do } \\
\text { Mundo } \\
\text { Segmento: Literatura juvenil } \\
\text { Ano Escolar: } 6^{\circ} \text { aos } 7^{\circ} \text { anos } \\
\text { ISBN: } 9788526292697 \\
\text { Edição: } 1\end{array}$ & Salim Hatubou & 2014 & $\begin{array}{l}\text { Cultura africana, contos da tradição oral } \\
\text { das ilhas Comores, filosofia }\end{array}$ & $\begin{array}{l}\text { As ilhas Comores ficam entre o continente africano e } \\
\text { Madagascar. É nesse arquipélago que o ingênuo e } \\
\text { irônico Madi vivencia situações inusitadas, nas quais } \\
\text { mostra toda a sua sabedoria. De uma ilha a outra, por } \\
\text { terra ou por mar, em palácios ou vilarejos e até mesmo } \\
\text { na floresta, as } 25 \text { histórias deste livro convidam o leitor } \\
\text { a seguir os passos desse viajante tolo - que de tolo, na } \\
\text { verdade, não tem nada. }\end{array}$ \\
\hline $\begin{array}{l}\text { Meninos em } \\
\text { guerra }\end{array}$ & $\begin{array}{l}\text { Editora: Ática } \\
\text { Coleção: Vasto Mundo } \\
\text { Segmento: Literatura juvenil } \\
\text { Ano Escolar: } 8^{\circ} \text { aos } 9^{\circ} \text { anos e }\end{array}$ & Jerry Piasecki & 2012 & $\begin{array}{l}\text { Cultura africana, crítica social, amizade, } \\
\text { guerra civil. }\end{array}$ & $\begin{array}{l}\text { Uma triste realidade é comum em vários países da } \\
\text { África: as guerras civis, que destroem populações e } \\
\text { impedem o progresso de gerações. Esse assunto } \\
\text { delicado é abordado em Meninos em guerra e pode ser } \\
\text { introduzido em sala de aula por meio da história de } \\
\text { Thomas e Deng, garotos sequestrados por milicianos e } \\
\text { forçados a guerrilhar. Torturas, ataques armados e } \\
\text { mortes passam a fazer parte do dia a dia, e eles precisam } \\
\text { esquecer que são adolescentes e lutar pela }\end{array}$ \\
\hline
\end{tabular}




\begin{tabular}{|c|c|c|c|c|c|}
\hline & $\begin{array}{l}\text { EM } \\
\text { ISBN: } 9788508156795 \\
\text { Edição:2 }\end{array}$ & & & & $\begin{array}{l}\text { sobrevivência. Uma lição de paz, que inspira o } \\
\text { enfrentamento das injustiças e do ódio que gera } \\
\text { preconceito e violência contra inocentes. }\end{array}$ \\
\hline TÍTULO & EDITORA/ SEGUIMENTO & AUTOR & ANO & TEMÁTICAS & SINÓPSE \\
\hline $\begin{array}{l}\text { Coração } \quad \text { das } \\
\text { trevas }\end{array}$ & $\begin{array}{l}\text { Editora: Scipione } \\
\text { Coleção: Reencontro } \\
\text { Literatura } \\
\text { Segmento: Literatura juvenil } \\
\text { Ano Escolar: } 6^{\circ} \text { aos } 7^{\circ} \text { anos } \\
\text { ISBN: } 9788526292659 \\
\text { Edição: } 1\end{array}$ & $\begin{array}{llll}\text { Joseph } & \text { Conrad, Ivan Jaf } \\
\text { (adap.) } & & & \end{array}$ & 2014 & $\begin{array}{l}\text { Culturas, violência, África, dominação, } \\
\text { adaptação de clássico da literatura } \\
\text { universal. }\end{array}$ & $\begin{array}{l}\text { Marlow é capitão de um barco a vapor na África. Seu } \\
\text { trabalho é transportar marfim rio abaixo. No entanto, } \\
\text { sua missão mais urgente é encontrar e trazer de volta o } \\
\text { famoso mercador de marfim Kurtz, cujos métodos } \\
\text { desagradam à companhia mercante que o contratou. Em } \\
\text { sua viagem pela selva, Marlow se depara com os limites } \\
\text { da razão humana ao testemunhar a violência dos } \\
\text { europeus contra os nativos, a corrupção dos traficantes e } \\
\text { a ganância descabida pelo marfim. O livro inspirou o } \\
\text { filme Apocalypse Now, de Francis Ford Coppola. }\end{array}$ \\
\hline $\begin{array}{l}\text { África e Brasil } \\
\text { africano }\end{array}$ & $\begin{array}{l}\text { Editora: Ática } \\
\text { Coleção: Avulso } \\
\text { Segmento: Informativo } \\
\text { juvenil } \\
\text { ISBN: } 9788508160525 \\
\text { Edição: } 3\end{array}$ & Marina de Mello e Souza & 2014 & História e cultura afro-brasileira & $\begin{array}{l}\text { Este livro traz um consistente panorama da formação do } \\
\text { continente e das sociedades africanas, o comércio de } \\
\text { escravos para a América e a integração de seus } \\
\text { descendentes à nossa } \\
\text { contemporaneidade. A obra } \\
\text { iconografia. }\end{array}$ \\
\hline $\begin{array}{l}\text { Capulana - Um } \\
\text { pano estampado } \\
\text { de histórias }\end{array}$ & $\begin{array}{l}\text { Editora: Scipione } \\
\text { Coleção: Avulso } \\
\text { Segmento: Literatura infantil } \\
\text { ISBN: } 9788526292611 \\
\text { Edição: } 1\end{array}$ & $\begin{array}{l}\text { Mário Lemos, Heloisa Pires } \\
\text { Lima }\end{array}$ & 2014 & $\begin{array}{l}\text { Língua portuguesa, cultura africana, } \\
\text { diferenças (aceitação), comportamento, } \\
\text { comunicação, pontos de vista, amizade, } \\
\text { memórias, família. }\end{array}$ & $\begin{array}{l}\text { Dandara, uma menina que mora em São Paulo, recebe } \\
\text { um presente de seu amigo Tulany, de Moçambique. É É } \\
\text { uma capulana! Na terra do garoto, o uso desse tecido é } \\
\text { tradição. Ele serve para muitas coisas: cobrir o corpo ou } \\
\text { a cabeça, enfeitar, carregar bebê nas costas, presentear } \\
\text { alguém em ocasiões especiais... A amizade entre as duas } \\
\text { crianças resgata uma bela tradição africana, ainda viva } \\
\text { entre os povos de Moçambique. }\end{array}$ \\
\hline
\end{tabular}




\begin{tabular}{|c|c|c|c|c|c|}
\hline TÍTULO & EDITORA/ SEGUIMENTO & AUTOR & ANO & TEMÁTICAS & SINÓPSE \\
\hline $\begin{array}{l}\text { O ninho de } \\
\text { cobras }\end{array}$ & $\begin{array}{l}\text { Editora: Ática } \\
\text { Coleção: The } 39 \text { Clues } \\
\text { Segmento: Literatura juvenil } \\
\text { Ano Escolar: } 6^{\circ} \text { aos } 7^{\circ} \text { anos } \\
\text { ISBN: } 9788508143931 \\
\text { Edição: } 1\end{array}$ & Peter Lerangis & 2011 & 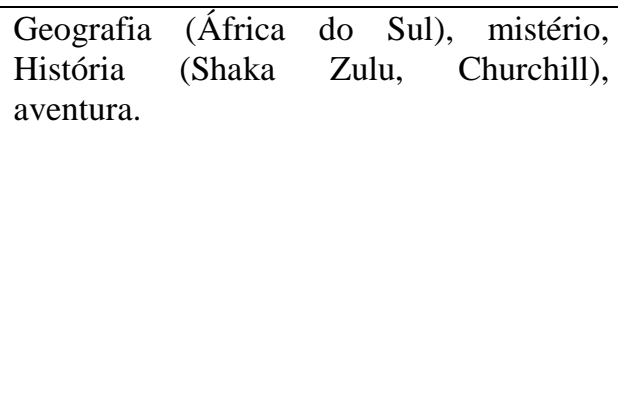 & $\begin{array}{l}\text { Os acontecimentos na Indonésia deixaram Amy e Dan } \\
\text { arrasados, mas eles devem continuar a busca pelas } \\
\text { pistas e pela verdade sobre a morte dos pais. A caça ao } \\
\text { tesouro dos Cahill os leva à África do Sul, onde um } \\
\text { segredo será revelado: o clã a que pertencem. }\end{array}$ \\
\hline $\begin{array}{l}\text { Contos africanos } \\
\text { dos países de } \\
\text { língua } \\
\text { portuguesa }\end{array}$ & $\begin{array}{l}\text { Editora: Ática } \\
\text { Coleção: Para Gostar de Ler } \\
\text { Segmento: Literatura juvenil } \\
\text { Ano Escolar: } 8^{\circ} \text { aos } 9^{\circ} \text { anos } \\
\text { ISBN: } 9788508120536 \\
\text { Edição: } 1\end{array}$ & $\begin{array}{l}\text { Boaventura Cardoso, Odete } \\
\text { Costa Semedo, José Eduardo } \\
\text { Agualusa, Nelson Saúte, } \\
\text { Luandino Vieira, Ondjaki, } \\
\text { Teixeira de Sousa, Albertino } \\
\text { Bragança, Luís Bernardo } \\
\text { Honwana, Mia Couto }\end{array}$ & 2009 & $\begin{array}{l}\text { Culturas, cultura, memórias, cotidiano, } \\
\text { guerra. }\end{array}$ & $\begin{array}{l}\text { Este livro traz dez contos dos mais representativos } \\
\text { escritores africanos contemporâneos de língua } \\
\text { portuguesa. Com base nessas narrativas é possível traçar } \\
\text { um cenário cultural e político dos países que têm o } \\
\text { português como uma de suas línguas oficiais. }\end{array}$ \\
\hline $\begin{array}{lll}\text { A cor } & \text { do } \\
\text { preconceito } & \end{array}$ & $\begin{array}{l}\text { Editora: Ática } \\
\text { Coleção: Jovem Cidadão } \\
\text { Segmento: Informativo } \\
\text { Juvenil } \\
\text { ISBN: } 9788508109371\end{array}$ & $\begin{array}{l}\text { Vera Vilhena, Carmen Lucia } \\
\text { Campos, Sueli Carneiro }\end{array}$ & 2007 & $\begin{array}{l}\text { Colonialismo africano, rap e movimento } \\
\text { hip-hop, apartheid, cultura, discriminação, } \\
\text { continente e cultura africanos, cultura } \\
\text { afro-brasileira, o negro na mídia, } \\
\text { linguagem e preconceito, mulheres negras, } \\
\text { o negro e a cultura, preconceito, } \\
\text { democracia racial, abolicionismo, } \\
\text { democracia. }\end{array}$ & $\begin{array}{l}\text { Mira é uma garota negra que mora na periferia e se } \\
\text { confronta com questões sobre sua identidade quando } \\
\text { percebe o racismo e o preconceito. }\end{array}$ \\
\hline
\end{tabular}




\begin{tabular}{|c|c|c|c|c|c|}
\hline & Edição: 2 & & & & \\
\hline TÍTULO & EDITORA/ SEGUIMENTO & AUTOR & ANO & TEMÁTICAS & SINÓPSE \\
\hline $\begin{array}{l}\begin{array}{l}\text { Zekeyêe vai à } \\
\text { escola }\end{array} \\
\end{array}$ & $\begin{array}{l}\text { Editora: Scipione } \\
\text { Coleção: Zekeyê } \\
\text { Segmento: Literatura infantil } \\
\text { ISBN: } 9788526292376 \\
\text { Edição: } 1\end{array}$ & Nathalie Dieterlé & 2014 & $\begin{array}{l}\text { Cultura africana, rito de passagem, } \\
\text { responsabilidade, independência. }\end{array}$ & $\begin{array}{l}\text { Zekeyê vai sozinho à escola pela primeira vez. Sua avó } \\
\text { recomenda que ele não saia do caminho. Mas Zekeyê } \\
\text { não resiste e para a fim de brincar com os macaquinhos. } \\
\text { Depois, aperta o passo para compensar o atraso. Porém, } \\
\text { fica curioso para explorar a mata e se atrasa ainda mais. } \\
\text { De novo na estrada, o garoto depara com pássaros } \\
\text { presos pedindo socorro. Zekeyê não pode parar, mas seu } \\
\text { coração fala mais alto e ele liberta as aves. Agora, ele } \\
\text { está mesmo atrasado! As aves levam o menino até a } \\
\text { escola. Ainda assim, ele é penalizado pelo atraso, só que } \\
\text { Zekeyêe consegue se sair bem no final. }\end{array}$ \\
\hline $\begin{array}{l}\text { Orum Ayê - Um } \\
\text { mito africano da } \\
\text { criação }\end{array}$ & $\begin{array}{l}\text { Editora: Scipione } \\
\text { Coleção: Avulso } \\
\text { Segmento: Literatura infantil } \\
\text { ISBN: } 9788526292536 \\
\text { Edição: } 1\end{array}$ & Raimundo Matos de Leão & 2014 & $\begin{array}{l}\text { Cultura africana, comportamento, lenda, } \\
\text { mitos. }\end{array}$ & $\begin{array}{l}\text { Este é um reconto de mitos africanos, narrados e } \\
\text { ritualizados pelos seguidores do candomblé até hoje. No } \\
\text { principio de tudo, Olorum, o senhor da vida, decide } \\
\text { criar um lugar para contemplar e orixás para ajudar a } \\
\text { governar esse lugar. Cabe a Oxalá, filho de Olorum, a } \\
\text { tarefa da criação. Porém, ele falha em sua missão, que } \\
\text { acaba sendo cumprida por seu irmão Odudua. Depois de } \\
\text { ser perdoado pelo pai, Oxalá cria o ser humano usando } \\
\text { barro. Deuses e homens convivem bem até que a } \\
\text { desobediência de um menino provoca a separação entre } \\
\text { o Orum (Céu) e o Ayê (Terra), e o mundo se torna o que } \\
\text { é hoje. }\end{array}$ \\
\hline $\begin{array}{l}\text { Zekeyêr e } \\
\text { os olhos da noite }\end{array}$ & $\begin{array}{l}\text { Editora: Scipione } \\
\text { Coleção: Zekeyê } \\
\text { Segmento: Literatura infantil } \\
\text { ISBN: } 9788526292352 \\
\text { Edição: } 1\end{array}$ & Nathalie Dieterlé & 2014 & $\begin{array}{l}\text { Cultura africana, deficiência visual, } \\
\text { heroísmo, superação, amizade, infância. }\end{array}$ & $\begin{array}{l}\text { Maína é uma menina cega, amiga de Zekeyê. Numa } \\
\text { tarde, as crianças decidem ir à cachoeira e se recusam a } \\
\text { levar a garota, porque teriam de ir mais devagar para } \\
\text { ajudá-la pelo caminho. Zekeyê fica com a amiga. Eles } \\
\text { brincam pra valer e só param quando cai uma } \\
\text { tempestade. Mas as outras crianças não retornam, pois a } \\
\text { chuva e a escuridão as impedem de achar o caminho de } \\
\text { volta. Como Maína tem os sentidos aguçados, Zekeyêe e } \\
\text { a menina resolvem resgatar os amigos. Ao encontrá-los, } \\
\text { eles estão encurralados por um leão. Com coragem e } \\
\text { inteligência, a dupla salva a turma. }\end{array}$ \\
\hline
\end{tabular}




\begin{tabular}{|c|c|c|c|c|c|}
\hline TÍTULO & EDITORA/ SEGUIMENTO & AUTOR & ANO & TEMÁTICAS & SINÓPSE \\
\hline $\begin{array}{ll}\text { O vampiro } & \text { e o } \\
\text { Zumbi } & \text { dos } \\
\text { Palmares } & \end{array}$ & $\begin{array}{l}\text { Editora: Ática } \\
\text { Coleção: Memórias } \\
\text { Sangue } \\
\text { Segmento: Literatura juvenil } \\
\text { Ano Escolar: } 8^{\circ} \text { aos } 9^{\circ} \text { anos e } \\
\text { EM } \\
\text { ISBN: } 9788508164837 \\
\text { Edição: } 1\end{array}$ & Ivan Jaf & 2013 & $\begin{array}{l}\text { Quilombos, história do Brasil e da África } \\
\text { (século XVII), vampiros, escravidão, } \\
\text { liberdade. }\end{array}$ & $\begin{array}{l}\text { Gaspar é vendido como escravo a um engenho em } \\
\text { Pernambuco. Graças aos ensinamentos de seu pai sobre } \\
\text { feitiçaria, ele consegue fugir. Na mata da Serra da } \\
\text { Barriga, vive só e em paz, mas o sossego acaba quando } \\
\text { outros fugitivos se juntam em um local vizinho. Os } \\
\text { brancos se aproximam e há um vampiro à espreita. } \\
\text { Gaspar, então, terá de decidir se fará parte da resistência } \\
\text { negra. }\end{array}$ \\
\hline Mitos africanos & $\begin{array}{l}\text { Editora: Scipione } \\
\text { Coleção: Mitos } \\
\text { Quadrinhos } \\
\text { Segmento: Literatura juvenil } \\
\text { Ano Escolar: } 6^{\circ} \text { aos } 7^{\circ} \text { anos } \\
\text { ISBN: } 9788526285194 \\
\text { Edição: } 1\end{array}$ & Gary Jeffrey & 2011 & $\begin{array}{l}\text { Cultura, civilizações, folclore, cultura } \\
\text { popular, História. }\end{array}$ & $\begin{array}{l}\text { Neste livro, o leitor tem a chance de conferir um pouco } \\
\text { da tradição oral africana que remonta a tempos } \\
\text { imemoriais. As lendas reunidas explicam como o } \\
\text { mundo foi criado e contam fábulas de personagens } \\
\text { trapaceiros e de animais que falam. }\end{array}$ \\
\hline $\begin{array}{l}\text { Ritmos } \\
\text { brasileiros }\end{array}$ & $\begin{array}{l}\text { Editora: Scipione } \\
\text { Coleção: Avulso } \\
\text { Segmento: Informativo } \\
\text { juvenil } \\
\text { Disciplina: Arte }\end{array}$ & Ricardo Elias & 2012 & $\begin{array}{l}\text { Arte, culturas, história, folclore, cultura } \\
\text { popular, música, História, poesia. }\end{array}$ & $\begin{array}{l}\text { Neste livro, o escritor aborda as três matrizes principais } \\
\text { da identidade musical do país: indígena, europeia e } \\
\text { africana. Em seguida, apresenta dez ritmos que } \\
\text { abrangem as cinco regiões do Brasil. São eles: samba, } \\
\text { frevo, baião, maracatu, boi-bumbá, carimbó, moda. }\end{array}$ \\
\hline
\end{tabular}




\begin{tabular}{|c|c|c|c|c|c|}
\hline & $\begin{array}{l}\text { ISBN: } 9788526286665 \\
\text { Edição: } 1\end{array}$ & & & & \\
\hline TÍTULO & EDITORA/ SEGUIMENTO & AUTOR & ANO & TEMÁTICAS & SINÓPSE \\
\hline $\begin{array}{l}\text { As minas do Rei } \\
\text { Salomão }\end{array}$ & $\begin{array}{l}\text { Editora: Scipione } \\
\text { Coleção: Reencontro } \\
\text { Literatura } \\
\text { Segmento: Literatura juvenil } \\
\text { Ano Escolar: } 6^{\circ} \text { aos } 7^{\circ} \text { anos } \\
\text { ISBN: } 9788526247727 \\
\text { Edição: } 11\end{array}$ & $\begin{array}{l}\text { Henry Rider Haggard, Werner } \\
\text { Zotz (adap.) }\end{array}$ & 2003 & $\begin{array}{l}\text { África, colonialismo inglês, adaptação de } \\
\text { clássico da literatura universal. }\end{array}$ & $\begin{array}{l}\text { Com a ajuda de Allan Quatermain, o barão inglês Henry } \\
\text { Curtis vai à África em busca de seu irmão Neville, } \\
\text { desaparecido quando procurava as lendárias minas do } \\
\text { rei Salomão. A eles junta-se o africano Umbopa. } \\
\text { Durante meses, os três enfrentam perigos terríveis. O } \\
\text { livro aborda a presença inglesa na África e o } \\
\text { colonialismo imperialista do século XIX. }\end{array}$ \\
\hline
\end{tabular}

ANEXO 4 - LEVANTAMENTO BIBLIOGRÁFICO - ARTIGOS QUE TRATAM DA LEI 10.639/2003 E SEUS DIRECIONAMENTOS AOS PROFESSORES

\begin{tabular}{l|l|l|l|l|l|l}
\hline TÍTULO & AUTORES & PALAVRAS CHAVE & RESUMO & OBJETIVO & JUSTIFICATIVA & METODOLOGIA \\
\hline
\end{tabular}




\begin{tabular}{|c|c|c|c|c|c|c|}
\hline $\begin{array}{l}\text { As práticas } \\
\text { pedagógicas de } \\
\text { trabalho com } \\
\text { relações étnico- } \\
\text { raciais na escola } \\
\text { na perspectiva } \\
\text { de Lei } \\
\text { 10.639/2003: } \\
\text { desafios para a } \\
\text { política } \\
\text { educacional e } \\
\text { indagações para } \\
\text { a pesquisa. }\end{array}$ & $\begin{array}{l}\text { Nilma, L. G.; Rodrigo, E. de Jesus. As } \\
\text { práticas pedagógicas de trabalho com } \\
\text { relações étnico-raciais na escola na } \\
\text { perspectiva de Lei 10.639/2003: desafios } \\
\text { para a política educacional e indagações para } \\
\text { a pesquisa. Educ. Revista. N 47. Curitiba, } \\
\text { jan/mar, 2013. } \\
\text { Disponível em: } \\
\text { < } \\
\text { <http://www.scielo.br/scielo.php?script=sci_ } \\
\text { arttext\&pid=S0104-40602013000100003 > } \\
\text { Acesso em: janeiro de 2016. }\end{array}$ & $\begin{array}{lr}\text { Educação; } & \text { relações } \\
\text { étnico-raciais; } & \text { práticas } \\
\text { pedagógicas; } & \text { Lei } \\
10.639 / 2003 . & \end{array}$ & 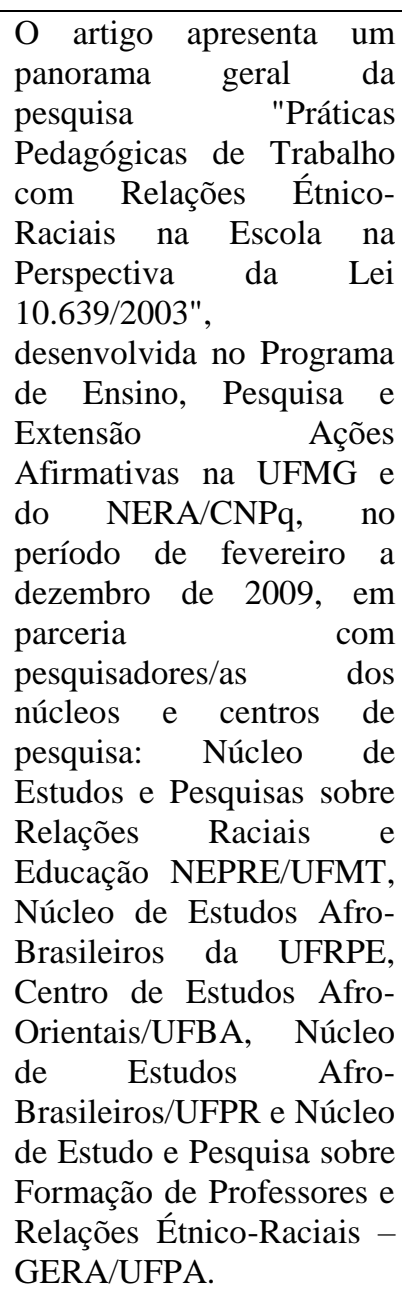 & $\begin{array}{l}\text { Mapear e analisar as } \\
\text { práticas pedagógicas } \\
\text { desenvolvidas pelas } \\
\text { escolas públicas e } \\
\text { pelas redes de ensino } \\
\text { de acordo com a Lei } \\
10.639 / 2003 \text {, a fim de } \\
\text { subsidiar e induzir } \\
\text { políticas e práticas de } \\
\text { implementação desta } \\
\text { Lei em nível nacional } \\
\text { em consonância com } \\
\text { o Plano Nacional de } \\
\text { Implementação das } \\
\text { Diretrizes } \\
\text { Curriculares a a a } \\
\text { Nacionais para a } \\
\text { Educação das } \\
\text { Relaçôs Étnico- } \\
\text { Raciais e para o } \\
\text { Ensino de História e } \\
\text { Cultura Afro- } \\
\text { Brasileira e Africana. }\end{array}$ & $\begin{array}{l}\text { Identificar como se } \\
\text { deu o processo de } \\
\text { implementação } \\
\text { dessa legislação - } \\
\text { que foi uma } \\
\text { alteração da LDB - } \\
\text { pela ra sua } \\
\text { imprescindibilidade } \\
\text { para compreender } \\
\text { os desafios da } \\
\text { política pública em } \\
\text { educação e a } \\
\text { diversidade, bem } \\
\text { como novos } \\
\text { elementos de } \\
\text { análise para a } \\
\text { pesquisa } \\
\text { educacional. }\end{array}$ & $\begin{array}{l}\text { Pesquisa } \\
\text { abordagem } \\
\text { quantitativa, uso de } \\
\text { questionário online, } \\
\text { seleção das escolas } \\
\text { analisados por meio } \\
\text { de indicação dos } \\
\text { NEAB's } \\
\text { conjunto com o } \\
\text { questionário } \\
\text { aplicado, para } \\
\text { posterior estudo de } \\
\text { caso acerca das } \\
\text { instituições } \\
\text { escolhidas. }\end{array}$ \\
\hline TÍTULO & AUTORES & PALAVRAS CHAVE & RESUMO & OBJETIVO & JUSTIFICATIVA & METODOLOGIA \\
\hline
\end{tabular}




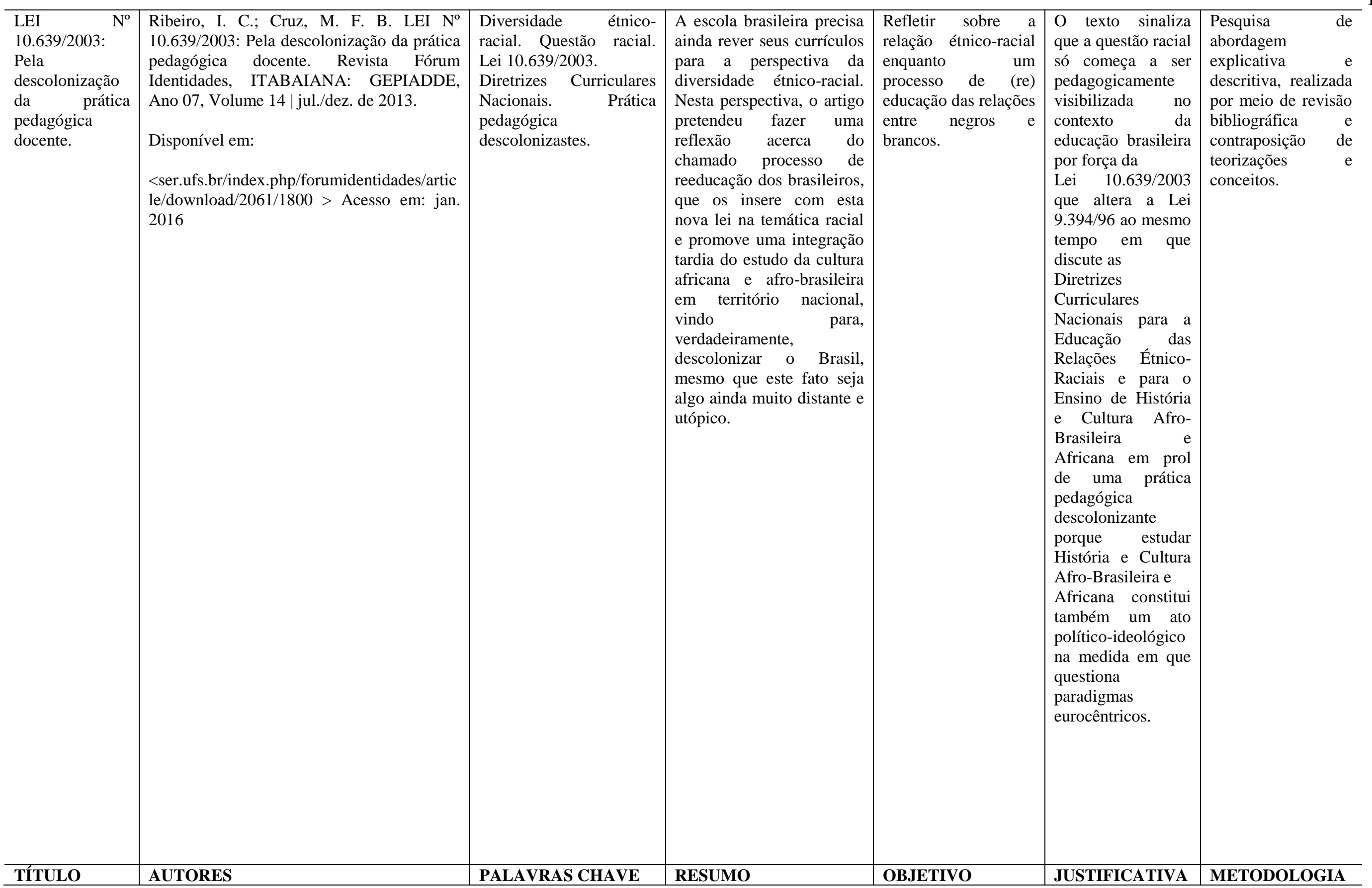




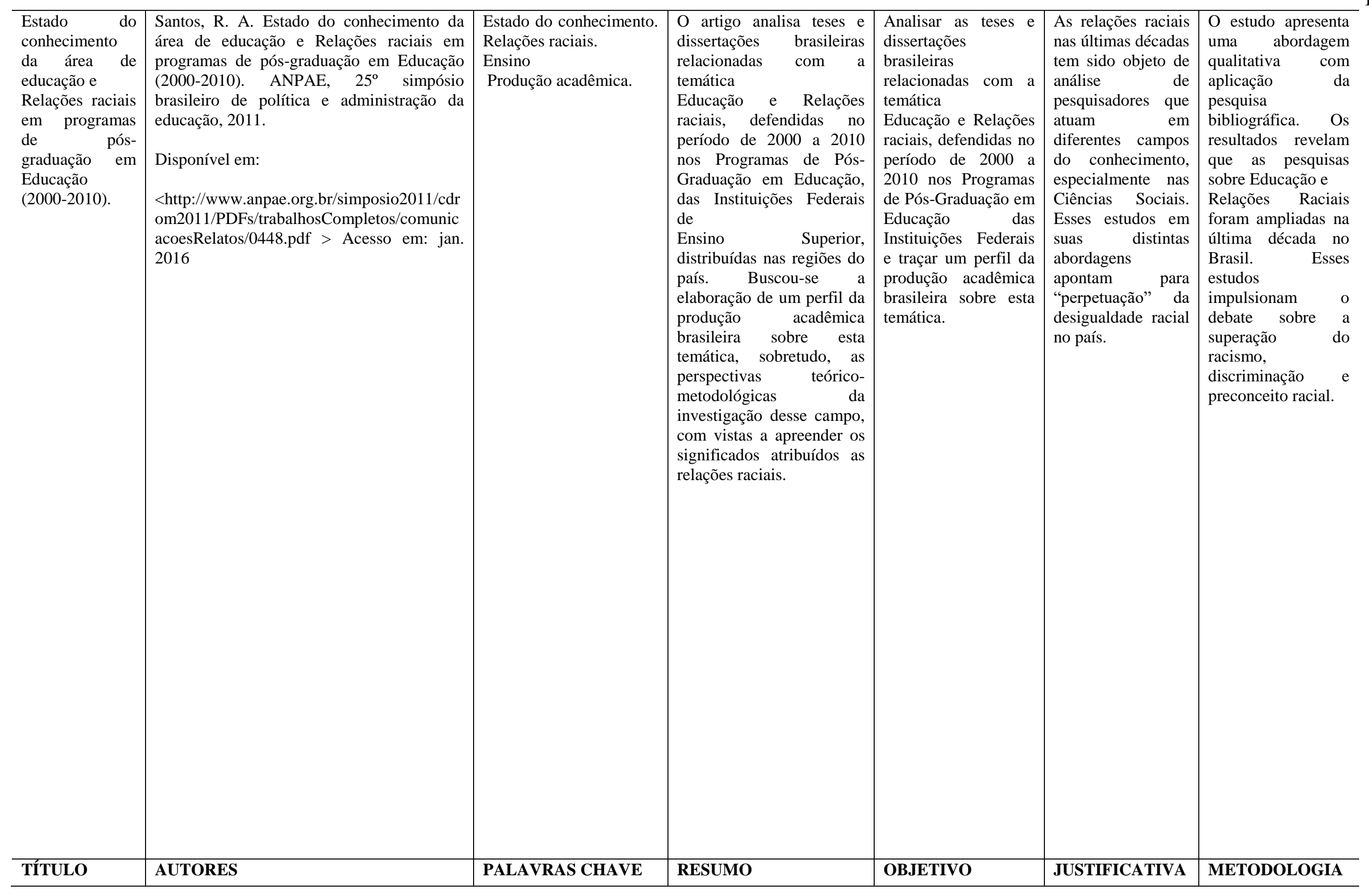




\begin{tabular}{|c|c|c|c|c|c|c|}
\hline $\begin{array}{l}\text { Breves } \\
\text { considerações } \\
\text { sobre o estado } \\
\text { do } \\
\text { conhecimento } \\
\text { na área de } \\
\text { formação de } \\
\text { professores } \\
\text { acerca da } \\
\text { educação para } \\
\text { as relações } \\
\text { étnico-raciais } \\
(2005-2009) .\end{array}$ & $\begin{array}{l}\text { Mendonça, A. P. F. Breves considerações } \\
\text { sobre o estado do conhecimento na ára de } \\
\text { formação de professores acerca da educação } \\
\text { para as relações étnico-raciais (2005-2009). } \\
\text { Revista Contrapontos - Eletrônica, Vol. } 11 \text { - } \\
\text { n. } 3 \text { - p. 299-313 / set-dez } 2011 . \\
\text { Disponível em: } \\
\text { <http://siaiap32.univali.br/seer/index.php/rc/ } \\
\text { article/view/2851/2030 > Acesso em: jan. } \\
2016\end{array}$ & $\begin{array}{l}\text { Formação de professores, } \\
\begin{array}{l}\text { Diversidade étnico- } \\
\text { racial, Educação. }\end{array}\end{array}$ & $\begin{array}{l}\text { O artigo trata do estado do } \\
\text { conhecimento na área de } \\
\text { formação de professores } \\
\text { acerca da educação para as } \\
\text { relações étnico-raciais. }\end{array}$ & $\begin{array}{l}\text { Mapear os estudos } \\
\text { realizados a partir da } \\
\text { diversidade étnico- } \\
\text { racial e sua interface } \\
\text { com a formação de } \\
\text { professores, } \\
\text { averiguando } \\
\text { elementos } \\
\text { pertinentes, como } \\
\text { referenciais teóricos, } \\
\text { reflexões } \\
\text { resultados, ou } \\
\text { destacando, ainda, } \\
\text { possíveis lacunas. }\end{array}$ & $\begin{array}{l}\text { Faz-se necessário } \\
\text { tratar dar } \\
\text { interlocução da } \\
\text { temática racial e da } \\
\text { educação, } \\
\text { apontando os fatos } \\
\text { que consolidaram a } \\
\text { luta dos } \\
\text { movimentos negros } \\
\text { até a promulgação } \\
\text { das legislações } \\
\text { atuais que preveem } \\
\text { a inclusão do } \\
\text { estudo da história } \\
\text { da África e da } \\
\text { cultura africana e } \\
\text { afro-brasileira. }\end{array}$ & $\begin{array}{lr}\begin{array}{lr}\text { Levantamento } \\
\text { dados }\end{array} & \begin{array}{r}\text { de } \\
\text { investigação } \\
\text { pesquisas }\end{array} \\
\text { disponíveis } \\
\text { Internet no período } \\
\text { entre } 2005 \text { e } 2009 \\
\text { que se envolvem na } \\
\text { temática apontada. }\end{array}$ \\
\hline $\begin{array}{l}\text { Uma reflexão } \\
\text { sobre o ensino } \\
\text { de História e } \\
\text { cultura } \\
\text { afrobrasileira e } \\
\text { africana e a } \\
\text { formação de } \\
\begin{array}{ll}\text { professores em } \\
\text { Sergipe }\end{array} \\
\end{array}$ & $\begin{array}{l}\text { Aguiar, J. C. T. M.; Aguiar, F. J. Uma } \\
\text { reflexão sobre o ensino de História e cultura } \\
\text { afro-brasileira e africana e a formação de } \\
\text { professores em Sergipe, Revista Fórum } \\
\text { Identidades Itabaiana: GEPIADDE, Ano 4, } \\
\text { Volume } 7 \text { |jan-jun de 2010. } \\
\text { Disponível em: } \\
\text { <http://200.17.141.110/periodicos/revista_fo } \\
\text { rum_identidades/revistas/ARQ_FORUM_IN } \\
\text { D_7/FORUM_V7_06.pdf > Acesso em: jan. } \\
\text { 2016 }\end{array}$ & $\begin{array}{lr}\text { Lei } & 10639 / 03, \\
\text { Diversidade, } & \text { Micro- } \\
\text { Ações Afirmativas, } \\
\text { Educação, Formação de } \\
\text { Professores. }\end{array}$ & $\begin{array}{l}\text { Este artigo apresenta uma } \\
\text { reflexão sobre a Lei } \\
\text { Federal n } \mathrm{n}^{\circ} 10639 / 03 \text { e o } \\
\text { processo de formação de } \\
\text { professores no estado de } \\
\text { Sergipe. }\end{array}$ & $\begin{array}{l}\text { O artigo destaca a } \\
\text { importância das } \\
\text { Micro-ações } \\
\text { afirmativas cotidianas } \\
\text { enquanto ações } \\
\text { voltadas à promoção } \\
\text { de discussões sobre a } \\
\text { História e a Cultura } \\
\text { Afro-Brasileira e } \\
\text { Africana em sala de } \\
\text { aula }\end{array}$ & 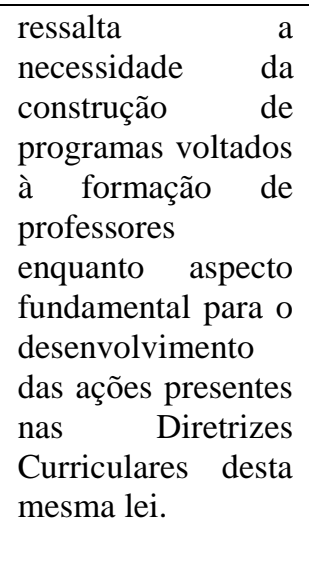 & $\begin{array}{lr}\text { Pesquisa } & \text { de } \\
\text { abordagem } & \\
\text { explicativa } & \text { e } \\
\text { descritiva, realizada } & \text { por meio de revisão } \\
\text { bibliográfica } & \text { e } \\
\text { contraposição } & \text { de } \\
\text { teorizações } & \text { e } \\
\text { conceitos além da } \\
\text { pesquisa de campo } \\
\text { junto a professores } \\
\text { que atuam em } \\
\text { escolas de Educação } \\
\text { básica }\end{array}$ \\
\hline
\end{tabular}




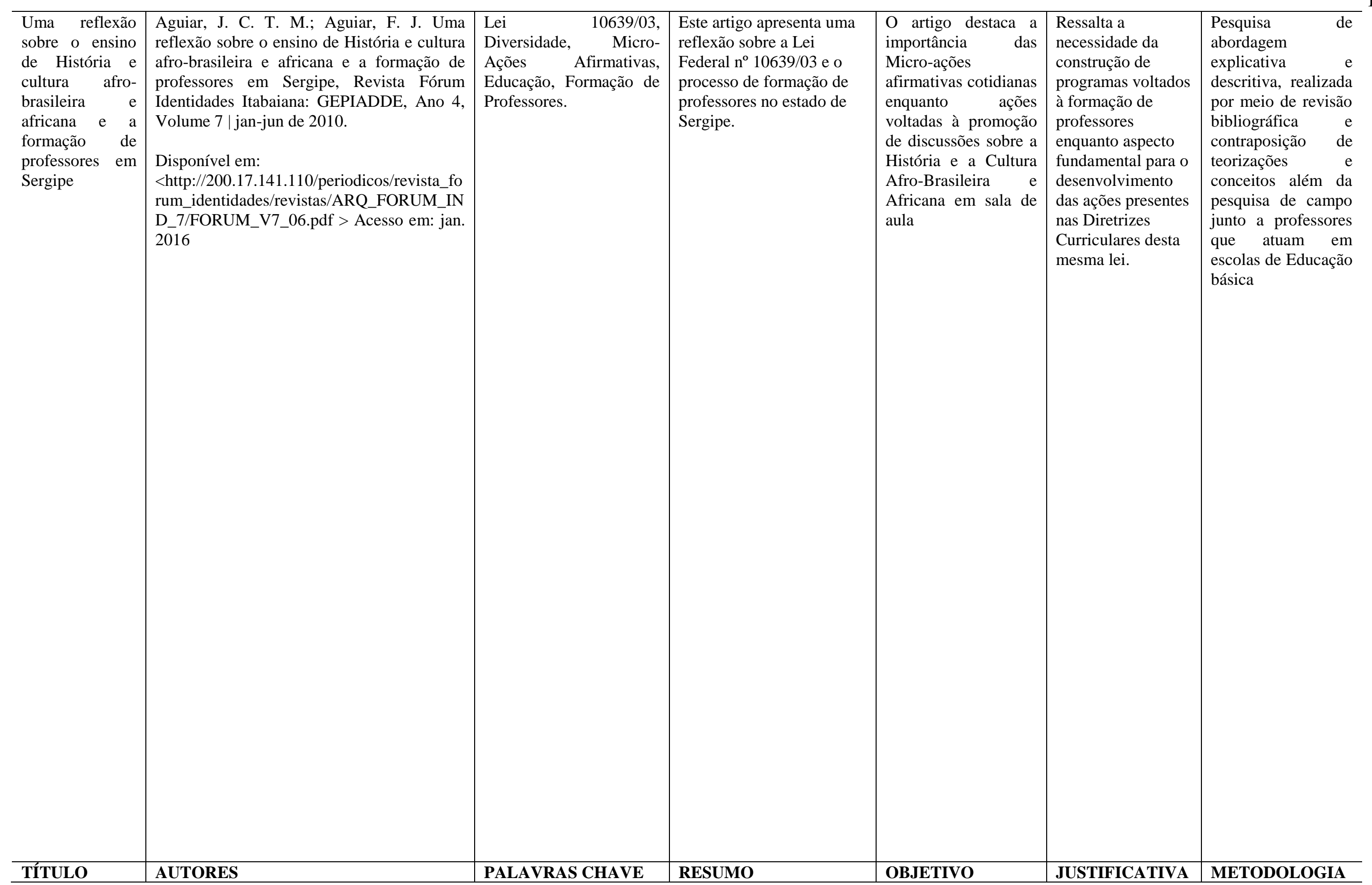




\begin{tabular}{|c|c|c|c|c|c|c|}
\hline $\begin{array}{lr}\text { A } & \text { história } \\
\text { africana } & \text { nos } \\
\text { cursos } & \text { de } \\
\text { formação } & \text { de } \\
\text { professores. } & \\
\text { Panorama, } & \\
\text { perspectivas } & \text { e } \\
\text { experiências } & \end{array}$ & $\begin{array}{l}\text { Oliva, A. R. A história africana nos cursos } \\
\text { de formação de professores. Panorama, } \\
\text { perspectivas e experiências Estudos Afro- } \\
\text { Asiáticos, Ano 28, nos 1/2/3, Jan-Dez 2006, } \\
\text { pp. 187-220. } \\
\text { Disponível em: } \\
\text { <http://repositorio.unb.br/bitstream/10482/6 } \\
\text { 224/1/ARTI } \\
\text { GO_Hist\%C3\%B3riaAfricanaCursosForma } \\
\text { \%C3\%A7\%C3\%A3oProfessores.pdf } \\
\text { Acesso em : fevereiro, 2016 }\end{array}$ & $\begin{array}{l}\text { África; História africana; } \\
\text { Ensino da História da } \\
\text { África; Cursos de } \\
\text { Formação de Professores }\end{array}$ & $\begin{array}{l}\text { O artigo resgata a } \\
\text { importância do debate } \\
\text { acerca da participação } \\
\text { africana na construção da } \\
\text { cultura } \\
\text { brasileira e a necessidade } \\
\text { de se construir um } \\
\text { currículo que possibilite a } \\
\text { visualização dessa } \\
\text { participação do negro em } \\
\text { nossa sociedade. }\end{array}$ & 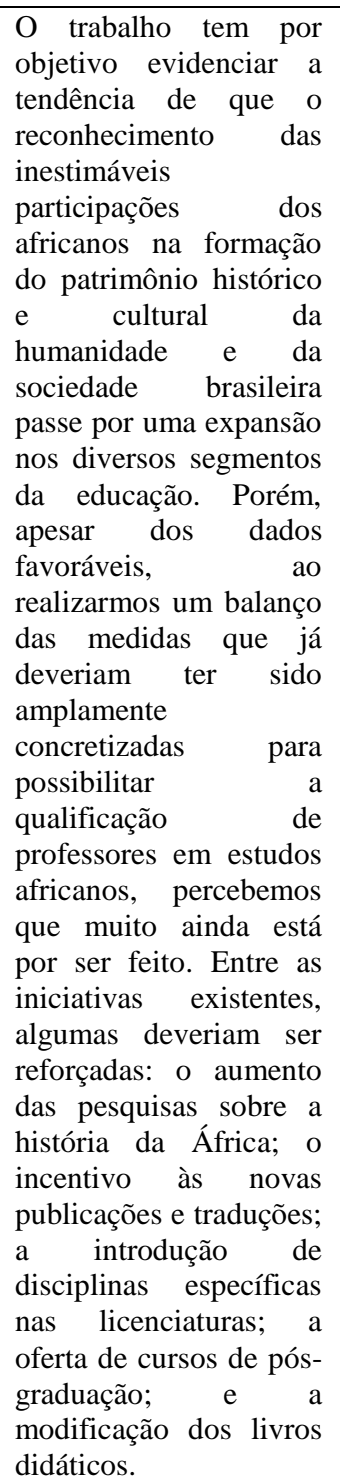 & $\begin{array}{l}\text { Vivenciamos nos } \\
\text { últimos anos um } \\
\text { importante debate } \\
\text { acerca do ensino da } \\
\text { História da África. } \\
\text { Acadêmicos, } \\
\text { professores, alunos } \\
\text { e intelectuais } \\
\text { participaram, em } \\
\text { vários espaços, de } \\
\text { experiências bem- } \\
\text { sucedidas. Também } \\
\text { é clara a tendência } \\
\text { de que o } \\
\text { reconhecimento } \\
\text { das inestimáveis } \\
\text { participações dos } \\
\text { africanos na } \\
\text { formação do } \\
\text { patrimônio } \\
\text { histórico e cultural } \\
\text { da humanidade e } \\
\text { da sociedade } \\
\text { brasileira passe por } \\
\text { uma expansão nos } \\
\text { diversos segmentos } \\
\text { da educação. }\end{array}$ & $\begin{array}{l}\text { Pesquisa } \\
\text { documental de } \\
\text { abordagem } \\
\text { explicativa realizada } \\
\text { por meio de revisão } \\
\text { bibliográfica }\end{array}$ \\
\hline TÍTULO & AUTORES & PALAVRAS CHAVE & RESUMO & OBJETIVO & JUSTIFICATIVA & METODOLOGIA \\
\hline
\end{tabular}




\begin{tabular}{|c|c|c|c|c|c|c|}
\hline $\begin{array}{lr}\text { Desafios } & \text { para o } \\
\text { ensino } & \text { de } \\
\text { História } & \mathrm{e} \\
\text { cultura } & \text { afro- } \\
\text { brasileira } & \mathrm{e} \\
\text { indígena } & \end{array}$ & $\begin{array}{l}\text { ROCHA, A. C. Desafios para o ensino de } \\
\text { História e cultura fro brasileira e indígena. } \\
\text { UNIFRA, XIV jornada nacional de } \\
\text { educação- Educação: territórios e saberes, } \\
2012 . \\
\text { Disponível em: } \\
\text { <http://jne.unifra.br/artigos/4811.pdf > } \\
\text { Acesso em: fevereiro, 2016 }\end{array}$ & $\begin{array}{l}\text { Afro-Indígena; Cultura; } \\
\text { Relações étnico-raciais; } \\
\text { Formação de professores }\end{array}$ & $\begin{array}{lr}\text { O artigo aborda } & \text { as } \\
\text { questões a partir } & \text { das } \\
\text { perspectivas sobre o ensino } \\
\text { de Historia e formação de } \\
\text { professores } & \text { que } \\
\text { desenvolvemos } & \text { nos } \\
\text { últimos anos } & \end{array}$ & $\begin{array}{l}\text { O objetivo é } \\
\text { apresentar algumas } \\
\text { bases teóricas que } \\
\text { referendam os nossos } \\
\text { estudos, como por } \\
\text { exemplo, } \\
\text { Bergamaschi }(2010), \\
\text { Bittencourt (2007), } \\
\text { Silva (2010), Funari/ } \\
\text { Piñoón (2011), } \\
\text { Oliveira (2012) entre } \\
\text { outros. }\end{array}$ & $\begin{array}{lr}\text { Apresenta } & \text { a } \\
\text { necessidade de } \\
\text { chamar a atenção } \\
\text { para a amplitude e } \\
\text { fertilidade do do } \\
\text { campo de pesquisa } \\
\text { além de apontar as } \\
\text { inquietações sobre } \\
\text { a realidade das } \\
\text { mesmas. }\end{array}$ & $\begin{array}{l}\text { Pesquisa } \\
\text { documental de } \\
\text { abordagem } \\
\text { explicativa realizada } \\
\text { por meio de revisão } \\
\text { bibliográfica. }\end{array}$ \\
\hline $\begin{array}{l}\text { Formação de } \\
\text { professores para } \\
\text { a } \\
\text { implementação } \\
\text { da Lei } \\
\text { 10.639/2003: o } \\
\text { ensino da } \\
\text { história e cultura } \\
\text { afro brasileira e } \\
\text { indígena no } \\
\text { currículo escolar }\end{array}$ & $\begin{array}{l}\text { Américo, M. C. Formação de professores } \\
\text { para a implementação da Lei 10.639/2003: o } \\
\text { ensino da história e cultura afro brasileira e } \\
\text { indígena no currículo escolar. Poiésis, } \\
\text { Tubarão. v.8, n.14, p. } 515 \text { a 534, Jul/Dez } \\
\text { 2014. } \\
\text { Disponível em: } \\
\text { <http://www.portaldeperiodicos.unisul.br/in } \\
\text { dex.php/Poiesis/article/viewFile/1540/1916 } \\
\text { > Acesso em: fevereiro, } 2016\end{array}$ & $\begin{array}{lr}\text { Lei } & 10.639 / 2003 ; \\
\text { Formação } & \text { de } \\
\text { Professores; } & \text { criança } \\
\text { negra } & \\
\end{array}$ & $\begin{array}{l}\text { O texto visa a apresentar } \\
\text { algumas reflexões sobre a } \\
\text { implementação da lei } \\
10.639 / 2003 \text {, alterada pela } \\
\text { Lei } 11.645 / 2008 \text {. }\end{array}$ & $\begin{array}{lr}\begin{array}{l}\text { Objetiva } \\
\text { algumas }\end{array} & \text { apresentar } \\
\text { sobre } & \text { reflexões } \\
\text { implementação da lei } \\
\text { 10.639/2003, alterada } \\
\text { pela Lei } 11.645 / 2008 .\end{array}$ & $\begin{array}{l}\text { Justifica-se a partir } \\
\text { da compreensão de } \\
\text { que a formação de } \\
\text { profissionais da } \\
\text { educação, } \\
\text { embasada } \\
\text { teoricamente na } \\
\text { compreensão dos } \\
\text { fundamentos da lei } \\
\text { e em ações que } \\
\text { visem a sua } \\
\text { implementação, } \\
\text { possibilita que a } \\
\text { infância nas } \\
\text { instituiçõos } \\
\text { educaionais seja } \\
\text { tratada como uma } \\
\text { construção } \\
\text { histórica, social, } \\
\text { cultural e política. }\end{array}$ & $\begin{array}{lr}\text { Pesquisa } & \text { de } \\
\text { abordagem } & \\
\text { explicativa } & \mathrm{e} \\
\text { descritiva, realizada } \\
\text { por meio de revisão } \\
\text { bibliográfica } \\
\text { contraposição } \\
\text { teorizações } \\
\text { conceitos. }\end{array}$ \\
\hline TÍTULO & AUTORES & PALAVRAS CHAVE & RESUMO & OBJETIVO & JUSTIFICATIVA & METODOLOGIA \\
\hline
\end{tabular}




\begin{tabular}{|c|c|c|c|c|c|c|}
\hline 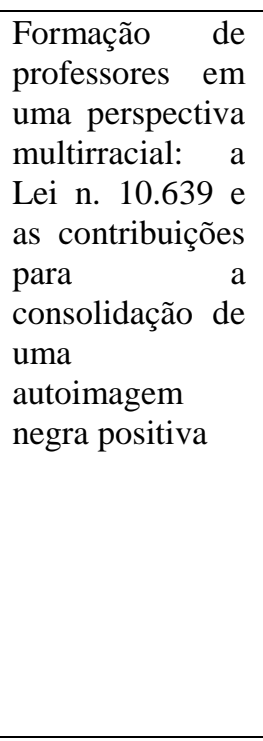 & $\begin{array}{l}\text { Américo, M. C; Luiz, V. Formação de } \\
\text { professores em uma perspectiva multirracial: } \\
\text { a Lei n. } 10.639 \text { e as contribuições para a } \\
\text { consolidação de uma autoimagem negra } \\
\text { positiva Revista identidade! São Leopoldo, } \\
\text { RS, v. 15, n. 2, jul.-dez. 2010. } \\
\text { Disponível em: } \\
\text { <http://periodicos.est.edu.br/index.php/ident } \\
\text { idade/article/view/31/149. Acesso em: } \\
\text { fevereiro } 2016\end{array}$ & $\begin{array}{lr}\text { Lei } & 10.639 / 2003 ; \\
\text { Formação } & \text { de } \\
\text { Professores; autoimagem }\end{array}$ & $\begin{array}{l}\text { O trabalho apresenta um } \\
\text { panorama geral das } \\
\text { práticas educativas mais } \\
\text { comuns de acordo com } \\
\text { registros de trabalho dos } \\
\text { professores de uma escola } \\
\text { de ensino fundamental e } \\
\text { médio de Santa Catarina }\end{array}$ & 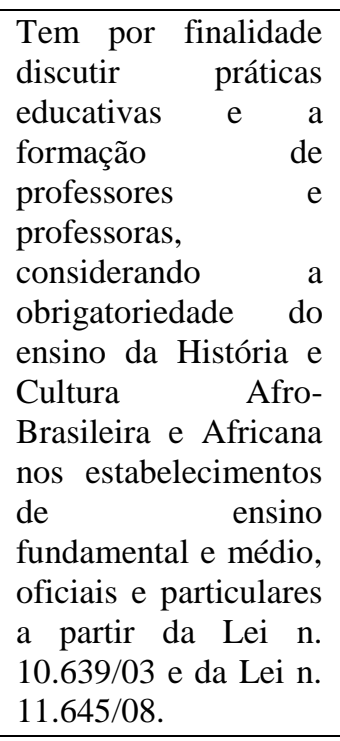 & $\begin{array}{lr}\text { Justifica-se } & \text { pela } \\
\text { necessidade } & \text { de } \\
\text { promover } & \text { uma } \\
\text { reflexão acerca dos } \\
\text { impactos } & \text { da } \\
\text { implementação da } \\
\text { Lei 10.639/2003 na } \\
\text { prática docente }\end{array}$ & $\begin{array}{l}\text { Pesquisa } \\
\text { abordagem } \\
\text { explicativa } \\
\text { descritiva, realizada } \\
\text { por meio de revisão } \\
\text { bibliográfica } \\
\text { contraposição de } \\
\text { teorizações } \\
\text { conceitos além da } \\
\text { pesquisa de campo } \\
\text { junto a professores } \\
\text { que atuam em } \\
\text { escolas de Educação } \\
\text { Básica }\end{array}$ \\
\hline $\begin{array}{l}\text { Percurso da lei } \\
\text { 10.639/2003: } \\
\text { Antecedentes e } \\
\text { desdobramentos }\end{array}$ & $\begin{array}{l}\text { Pereira, M. M; Silva, M. Percurso da lei } \\
\text { 10.639/2003: Antecedentes } \\
\text { desdobramentos. Revista Linguagens } \\
\text { cidadania, Ano } 16 \mathrm{~N}^{\circ} 1 \text { Jan-dez } 2014 . \\
\text { Disponível em } \\
\\
\text { <http://jararaca.ufsm.br/websites/l\&c/downl } \\
\text { oad/Artigos12/marc_mauric.pdf.pdf } \\
\text { Acesso em: fevereiro de } 2016\end{array}$ & $\begin{array}{lr}\text { Ensino de } & \text { Literatura, } \\
\text { Literatura } & \text { Africana } \\
\text { Lusófona, Escola, Lei } \\
10639 .\end{array}$ & $\begin{array}{l}\text { O trabalho apresenta expor } \\
\text { algumas considerações a } \\
\text { respeito da lei } 10639 / 03 \text {, a } \\
\text { qual institui a } \\
\text { obrigatoriedade do ensino } \\
\text { de história e cultura } \\
\text { africana e afro-brasileira } \\
\text { nas escolas e o ensino de } \\
\text { literatura }\end{array}$ & 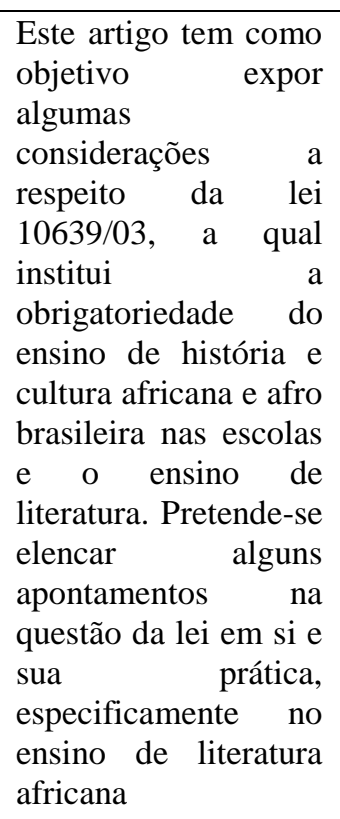 & 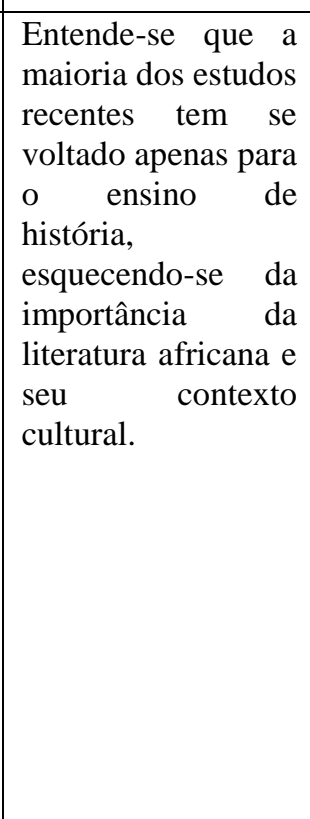 & $\begin{array}{lr}\text { Pesquisa } & \text { de } \\
\text { abordagem } & \\
\text { explicativa } & \text { e } \\
\text { descritiva, realizada } \\
\text { por meio de revisão } \\
\text { bibliográfica r } \\
\text { contraposição } & \text { de } \\
\text { teorizações } & \text { e } \\
\text { conceitos }\end{array}$ \\
\hline TÍTULO & AUTORES & PALAVRAS CHAVE & RESUMO & OBJETIVO & JUSTIFICATIVA & METODOLOGIA \\
\hline
\end{tabular}




\begin{tabular}{|c|c|c|c|c|c|c|}
\hline 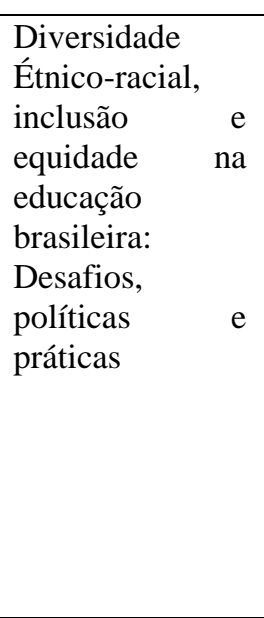 & $\begin{array}{l}\text { Gomes, N. L. Diversidade Étnico-racial, } \\
\text { inclusão e equidade na educação brasileira: } \\
\text { Desafios, políticas e práticas. ANPAE, } \\
\text { Congresso, Ibero, Luso, Brasileiro, } 2010 \text {. } \\
\text { Disponível em < } \\
\text { <http://www.anpae.org.br/iberolusobrasileir } \\
\text { o2010/cdrom/94.pdf > Acesso em: fevereiro, } \\
2016\end{array}$ & $\begin{array}{lr}\text { diversidade étnico-racial; } \\
\text { políticas } & \text { educacionais; } \\
\text { equidade; movimentos } \\
\text { sociais. }\end{array}$ & $\begin{array}{l}\text { O artigo pretende auxiliar } \\
\text { o debate sobre inclusão, } \\
\text { diversidade e equidade na } \\
\text { educação começa a ocupar } \\
\text { um lugar mais destacado } \\
\text { possibilitando indagações, } \\
\text { problematizações, desafios } \\
\text { e redirecionamentos das } \\
\text { políticas e das práticas } \\
\text { realizadas pelo Ministério } \\
\text { da Educação, pela gestão } \\
\text { dos sistemas de ensino e } \\
\text { pelas escolas. }\end{array}$ & $\begin{array}{lr}\text { Promover } & \text { o debate } \\
\text { sobre } & \text { inclusão, } \\
\text { diversidade } & \text { e } \\
\text { equidade } & \text { na } \\
\text { educação. } & \end{array}$ & $\begin{array}{l}\text { A educação } \\
\text { brasileira tem sido } \\
\text { apontada pelas } \\
\text { pesquisas oficiais e } \\
\text { acadêmicas, assim } \\
\text { como pelos } \\
\text { movimentos sociais } \\
\text { e, em especial pelo } \\
\text { Movimento Negro, } \\
\text { como um } \\
\text { espaço/tempo no } \\
\text { qual persistem } \\
\text { históricas } \\
\text { desigualdades } \\
\text { sociais e raciais. }\end{array}$ & $\begin{array}{lr}\text { Pesquisa } & \text { de } \\
\text { abordagem } & \\
\text { explicativa } & \mathrm{e} \\
\text { descritiva, realizada } \\
\text { por meio de revisão } \\
\text { bibliográfica } \\
\text { contraposição } \\
\text { teorizações } \\
\text { conceitos }\end{array}$ \\
\hline $\begin{array}{l}\text { Relações étnico- } \\
\text { raciais na } \\
\text { educação } \\
\text { infantil: } \\
\text { implementação } \\
\text { da la lei } \\
\text { 10.639/2003. }\end{array}$ & $\begin{array}{l}\text { Oramísio, A.S.; Costa, O. H. Relações étnico } \\
\text { raciais na educação infantil: implementação } \\
\text { da lei } 10.639 / 2003 \text {, Fundação Cultural } \\
\text { Palmares, 2010. } \\
\text { Disponível em: } \\
\text { < http://www.palmares.gov.br/wp-com } \\
\text { ent/uploads/2010/11/RELA\%C3\%87\%C3\% } \\
\text { 95ES-\%C3\%89TNICO-RACIAIS-NA- } \\
\text { EDUCA\%C3\%87\%C3\%83O- } \\
\text { INFANTIL.pdf > Acesso em: fevereiro, } \\
\text { 2016 }\end{array}$ & $\begin{array}{lrr}\text { educação } & \text { infantil, } \\
\text { racismo } & \text { e } & \text { relações } \\
\text { étnicos- } & \text { raciais, } & \text { Lei } \\
10.639 / 2003, & \text { cultura } \\
\text { negra. } & \end{array}$ & 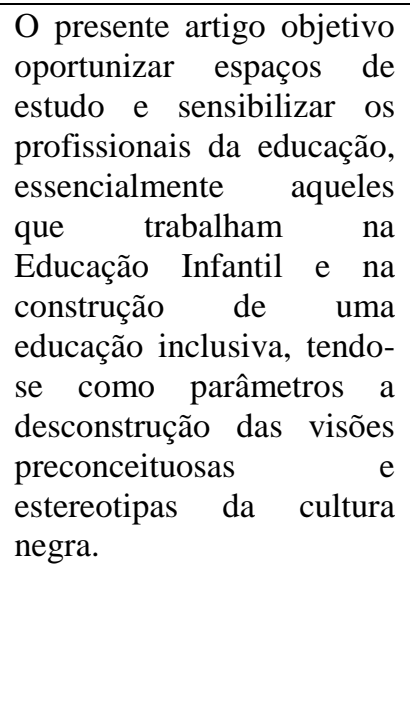 & 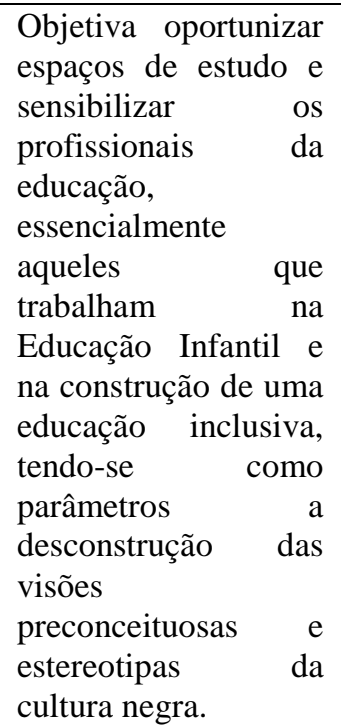 & $\begin{array}{l}\text { A necessidade de } \\
\text { se promover a } \\
\text { discussão sobre a s } \\
\text { relações Étnico } \\
\text { raciais no espaço } \\
\text { escolar como forma } \\
\text { venceras sérias } \\
\text { barreiras à cultura } \\
\text { afro-brasileira nas } \\
\text { escolas }\end{array}$ & $\begin{array}{lr}\text { Pesquisa } & \text { de } \\
\text { abordagem } & \\
\text { explicativa } & \text { e } \\
\text { descritiva, realizada } \\
\text { por meio de revisão } \\
\text { bibliográfica } \\
\text { contraposição } \\
\text { teorizações } \\
\text { conceitos }\end{array}$ \\
\hline TíTULO & AUTORES & PALAVRAS CHAVE & RESUMO & OBJETIVO & JUSTIFICATIVA & METODOLOGIA \\
\hline
\end{tabular}




\begin{tabular}{|c|c|c|c|c|c|c|}
\hline $\begin{array}{lr}\text { Formação } & \text { de } \\
\text { professores à luz } \\
\text { da história e } \\
\text { cultura } & \text { afro- } \\
\text { brasileira } & \mathrm{e} \\
\text { africana: } & \text { novos } \\
\text { desafios para } \\
\text { uma prática } \\
\text { reflexiva }\end{array}$ & $\begin{array}{l}\text { Oramísio, A. S. Formação de professores à } \\
\text { luz da história e cultura afro-brasileira e } \\
\text { africana: novos desafios para uma prática } \\
\text { reflexiva. Revista Eletrônica Acolhendo a } \\
\text { Alfabetização nos Países de Língua } \\
\text { Portuguesa, 2013. } \\
\text { Disponível em: } \\
\text { <http://www.revistas.usp.br/reaa/article/vie } \\
\text { wFile/11516/13284 > Acesso em: fevereiro, } \\
2016 \text { : }\end{array}$ & $\begin{array}{lr}\text { educação e relações } \\
\text { étnico-raciais; } \text { Lei n } \text { no }^{\circ} \\
10.639 / 2003 ; & \text { formação } \\
\text { de professores; currículo } \\
\text { escolar }\end{array}$ & $\begin{array}{l}\text { O presente trabalho busca } \\
\text { provocar discussões no } \\
\text { sentido de analisar, refletir } \\
\text { e problematizar a formação } \\
\text { docente a educação das } \\
\text { relações étnico-raciais na } \\
\text { formação inicial e } \\
\text { continuada de docentes da } \\
\text { educação básica. }\end{array}$ & 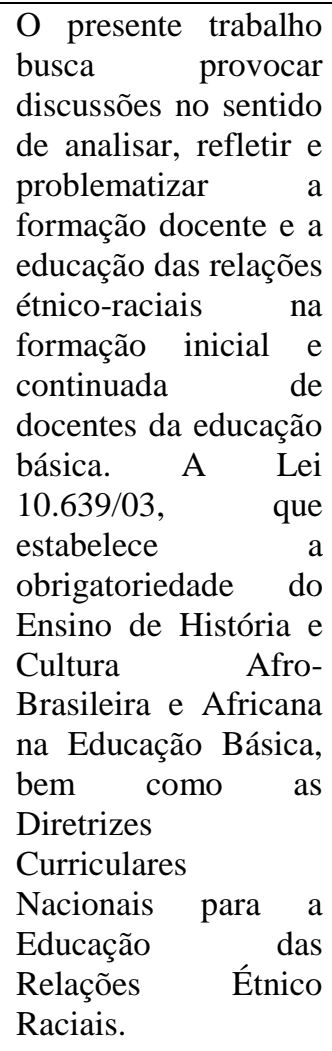 & $\begin{array}{l}\text { A formação } \\
\text { docente deve } \\
\text { instrumentalizar os } \\
\text { professores para } \\
\text { que estes venham a } \\
\text { desenvolver em } \\
\text { sala de aula } \\
\text { conteúdos, } \\
\text { metodologias } \\
\text { práticas } \\
\text { contemplem que } \\
\text { história e cultura } \\
\text { do } \\
\text { difundindo negro, } \\
\text { conhecimentos } \\
\text { base do que vem a } \\
\text { contemplar a } \\
\text { cultura africana } \\
\text { afro-brasileira. }\end{array}$ & $\begin{array}{l}\text { A pesquisa tem } \\
\text { como referência } \\
\text { metodológica um } \\
\text { estudo bibliográfico } \\
\text { e análise } \\
\text { documental. }\end{array}$ \\
\hline
\end{tabular}




\begin{tabular}{|c|c|c|c|c|c|c|}
\hline $\begin{array}{ll}\text { O uso da lei } \\
10.639 / 03 & \text { em } \\
\text { sala de aula. } & \end{array}$ & $\begin{array}{l}\text { Guedes, E.; Nunes, P.; Andrade, T. O uso da } \\
\text { lei } 10.639 / 03 \text { em sala de aula. Revista } \\
\text { Latino-Americana de História Vol. 2, no. } 6 \text { - } \\
\text { Agosto de } 2013 \text { - Edição Especial. } \\
\text { Disponível em } \\
\text { <http://projeto.unisinos.br/rla/index.php/rla/ } \\
\text { article/viewFile/205/159 > Acesso em: } \\
\text { fevereiro, 2016. }\end{array}$ & $\begin{array}{l}\text { Lei } 10.639 / 03 \text {. Cultura } \\
\text { africana. Educação }\end{array}$ & $\begin{array}{l}\text { O presente artigo buscará } \\
\text { fazer uma análise sobre a } \\
\text { Lei } 10.639 \text {, que entrou em } \\
\text { vigor no ano de } 2003 \text {, } \\
\text { tornando obrigatório o } \\
\text { ensino da História e } \\
\text { cultura africana e afro- } \\
\text { brasileira nas instituições } \\
\text { de ensino básico. }\end{array}$ & 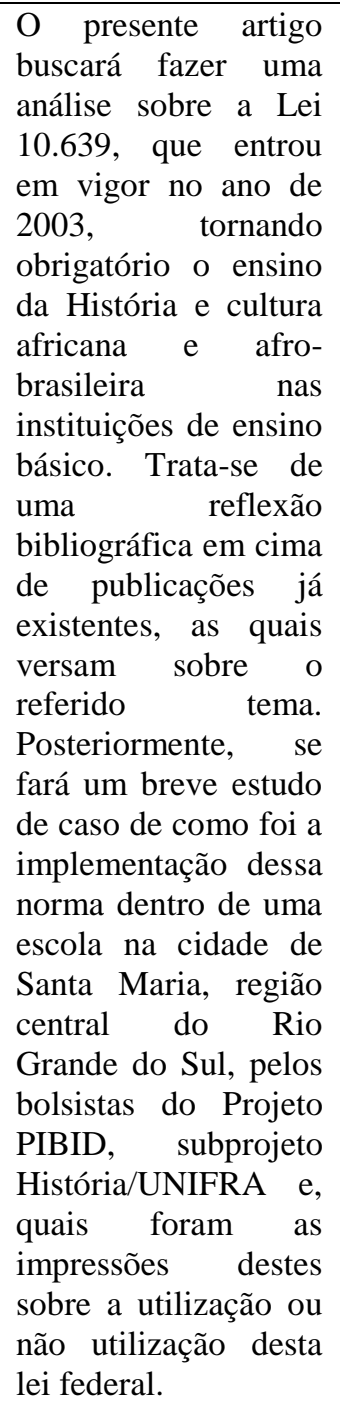 & $\begin{array}{l}\text { A educação exerce } \\
\text { um papel } \\
\text { determinante para o } \\
\text { agravamento e } \\
\text { superação } \\
\text { preocuação com a } \\
\text { situação do negro } \\
\text { no Brasil assume } \\
\text { uma importância } \\
\text { ainda } \\
\text { maior a se } \\
\text { comparada a outras } \\
\text { nações, pois aqui } \\
\text { esta herança da } \\
\text { África está mais } \\
\text { presente, } \\
\text { porém menos } \\
\text { valorizada. }\end{array}$ & $\begin{array}{l}\text { A pesquisa foi de } \\
\text { cunho qualitativo, } \\
\text { utilizou } \\
\text { procedimentos } \\
\text { metodológicos de } \\
\text { análise documental, } \\
\text { entrevistas r e } \\
\text { observações de } \\
\text { campo. r A } \\
\text { perspectiva teórica } \\
\text { que referendou as } \\
\text { análises foi o } \\
\text { transculturalismo } \\
\text { crítico, em fase de } \\
\text { construção. }\end{array}$ \\
\hline TíTULO & AUTORES & PALAVRAS CHAVE & RESUMO & OBJETIVO & JUSTIFICATIVA & METODOLOGIA \\
\hline
\end{tabular}




\begin{tabular}{|c|c|c|c|c|c|c|}
\hline $\begin{array}{l}\text { Livros } \\
\text { didáticos: } \\
\text { contribuição } \\
\text { para a pplicação } \\
\text { no ensino de } \\
\text { história e cultura } \\
\text { afro-brasileira } \\
\text { em instituições } \\
\text { de ensino } \\
\text { públicos e } \\
\text { particulares }\end{array}$ & $\begin{array}{l}\text { Santos, U. G. Livros didáticos: contribuição } \\
\text { para a aplicação no ensino de história e } \\
\text { cultura afro-brasileira em instituições de } \\
\text { ensino públicos e particulares. Revista } \\
\text { África e Africanidades - Ano } 3 \text { - n. 10, } \\
\text { agosto, 2010. } \\
\text { Disponível em: } \\
\text { <http://www.africaeafricanidades.com.br/do } \\
\text { cumentos/10082010_24.pdf > Acesso em: } \\
\text { março de 2016 }\end{array}$ & 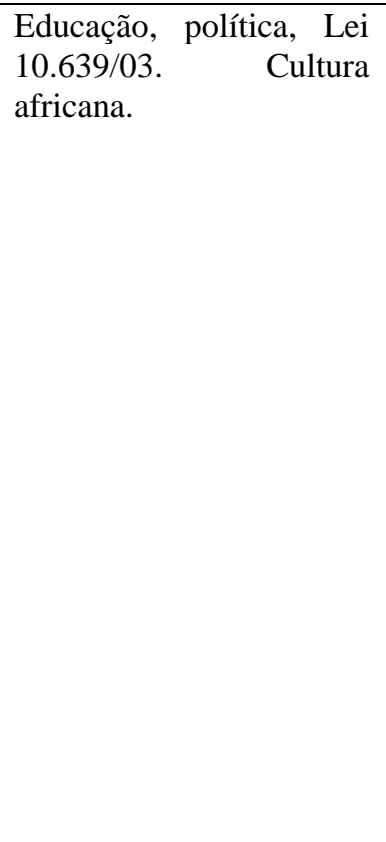 & $\begin{array}{l}\text { O artigo pretende expor e } \\
\text { discutir uma experiência d } \\
\text { matérias didáticos o estado } \\
\text { da Bahia onde pretendeu- } \\
\text { se atender ao que } \\
\text { determina a legislação em } \\
\text { vigor acerca do ensino das } \\
\text { culturas africanas e afro - } \\
\text { brasileiras. }\end{array}$ & $\begin{array}{l}\text { O artigo tem por } \\
\text { objetivo apresentar } \\
\text { uma experiência } \\
\text { inédita ocorrida no } \\
\text { estado da Bahia em } \\
\text { relação a elaboração } \\
\text { de livros didáticos } \\
\text { acerca da história da } \\
\text { África, ara, afro- } \\
\text { brasileira-brasileira e } \\
\text { indígena } \\
\text { atendimentos as leis } \\
10.639 / 2003\end{array}$ & $\begin{array}{l}\text { As } \\
10.639 / 2003 \text { Leis } \\
11.645 / 2008 \text { foram } \\
\text { criadas com o } \\
\text { objetivo de corrigir } \\
\text { injustiças históricas } \\
\text { e relação ao ensino } \\
\text { de histórica e } \\
\text { cultura africana. } \\
\text { Nesse contexto, a } \\
\text { publicação de } \\
\text { livros didáticos } \\
\text { sobre essas } \\
\text { temáticas tem } \\
\text { crescido, } \\
\text { principalmente em } \\
\text { virtude } \\
\text { necessidade da } \\
\text { expressa desses } \\
\text { materias para o } \\
\text { exercício docente. }\end{array}$ & $\begin{array}{l}\text { A pesquisa foi de } \\
\text { cunho qualitativo, } \\
\text { utilizou } \\
\text { procedimentos } \\
\text { metodológicos de } \\
\text { análise documental, } \\
\text { entrevistas e } \\
\text { observações de } \\
\text { campo. } \\
\text { perspectiva teórica } \\
\text { que referendou as } \\
\text { análises foi o } \\
\text { transculturalismo } \\
\text { crítico, em fase de } \\
\text { constituição. }\end{array}$ \\
\hline
\end{tabular}




TÍTULO

\section{Lei}

10.639/2003:

por

educação

antirracismo no

Brasil

\section{AUTORES}

Silva, T. F. O. Lei 10.639/2003: por uma educação antirracismo no Brasil. Revista interdisciplinar Ano VII, V.16, jul-dez de 2012 - ISSN 1980-8879 |p. 103-116.

\section{Disponível em:}

<http://www.seer.ufs.br/index.php/interdisci plinar/article/view/1010 >. Acesso em: fevereiro, 2016.

\section{PALAVRAS CHAVE

Educação. Diretrizes. Lei

$10639 / 03$.

Lei Federal 10.639/03 e

das Diretrizes Curriculares

Nacionais para a

implementação dessa lei,

este artigo discute e

reivindica que as propostas

de reparação à população

negra, presentes nessas

políticas de ações

afirmativas, sejam

efetivamente praticadas

dentro das escolas, a partir

da construção de um

currículo que atenda a

essas demandas. Para isso,

além da Lei e das

Diretrizes, discutimos a

relação entre raça e

educação.

\section{OBJETIVO}

$\mathrm{O}$ artigo pretende

discutir a s propostas

de reparação

população negra no

âmbito escolar e

relação entre raça e

educação.
JUSTIFICATIVA

Ainda que as

discussões das

relações étnico-

raciais

incloncusas,

escolas, espaços

privilegiados de

poder,

podem usar o seu

poder

influenciar a ordem

do mundo e nos

encorajar para

agirmos

contra discursos

hegemônicos que

querem dominar e

silenciar os grupos

étnicos

racialmente

minoritarizados.
METODOLOGIA

A pesquisa tem

como referência

metodológica um

estudo bibliográfico

documental.

análise

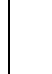




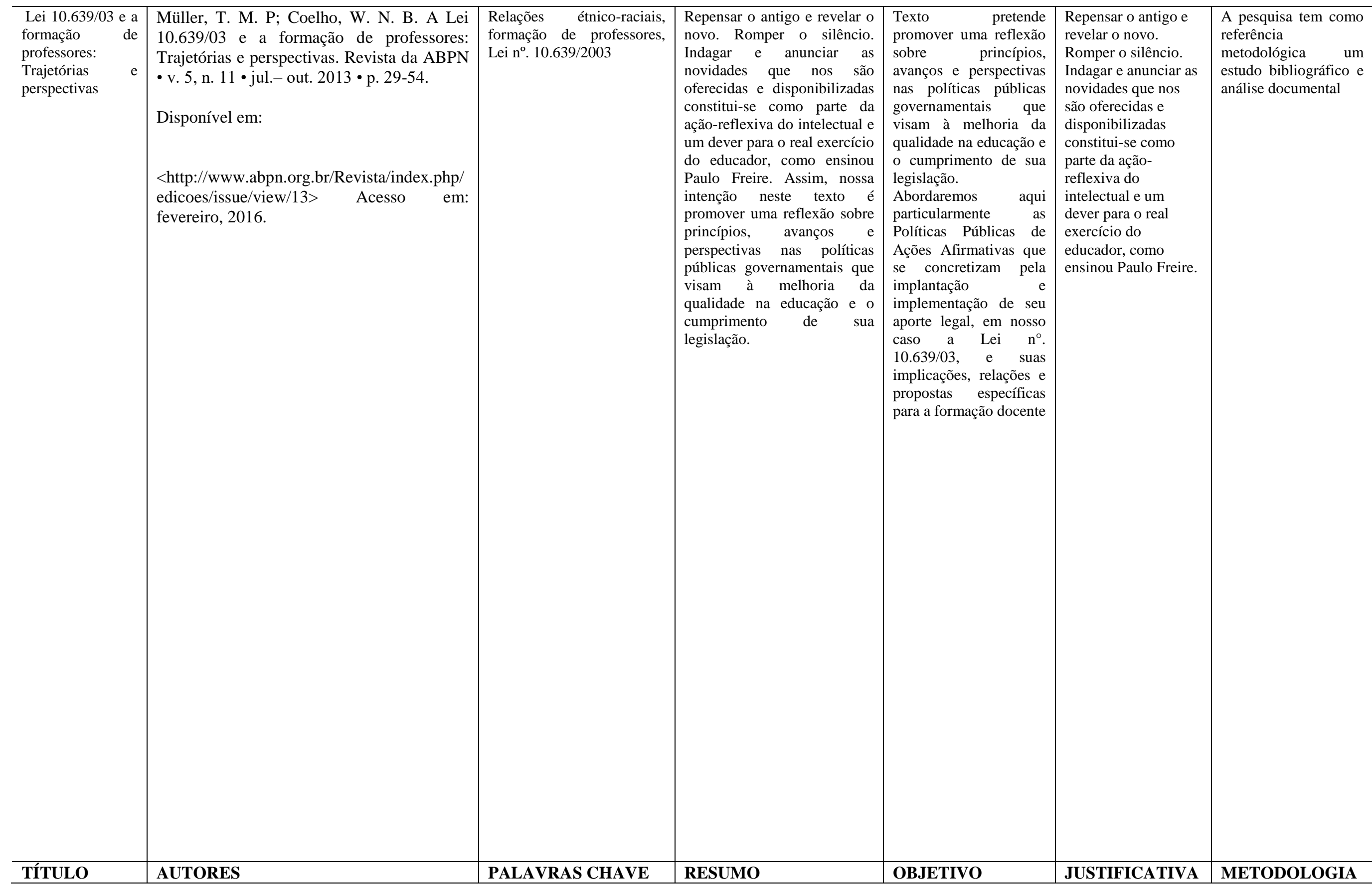




\begin{tabular}{|c|c|c|c|c|c|c|}
\hline $\begin{array}{l}\text { A implantação } \\
\text { da } \quad \text { Lei } \\
10.639 / 2003 \text { em } \\
\text { uma escola da } \\
\text { rede pùblica } \\
\text { estadual, no } \\
\text { ensino } \\
\begin{array}{l}\text { fundamental, na } \\
\text { cidade } \\
\text { Curitiba - PR }\end{array}\end{array}$ & $\begin{array}{l}\text { Pacífico, T. M. A implantação da Lei } \\
\text { 10.639/2003 em uma escola da rede pública } \\
\text { estadual, no ensino fundamental, na cidade e } \\
\text { Curitiba - PR. } 8^{\circ} \text { Congresso Nacional de } \\
\text { educação - Educere, 2008. } \\
\text { Disponível em : } \\
\text { http://www.pucpr.br/eventos/educere/educer } \\
\text { e2008/anais/pdf/259_680.pdf >. Acesso } \\
\text { em:fevereiro, 2016. }\end{array}$ & $\begin{array}{l}\text { Lei n. }{ }^{\circ} \quad 10639 / 03 ; \\
\text { Educação; Cultura afro- } \\
\text { brasileira; Auto estima; } \\
\text { História da África. }\end{array}$ & $\begin{array}{l}\text { Este estudo analisou as } \\
\text { implicações } \\
\text { implantação da lei n. } \\
10639 \text { de } 9 \text { de janeiro de } \\
2003 \text {. Na condição de } \\
\text { pedagoga negra, discuto a } \\
\text { ação dos professores como } \\
\text { mediadores nas questões } \\
\text { relacionadas à diversidade } \\
\text { racial nas escolas e } \\
\text { comunidades. Analisou-se } \\
\text { a implementação da Lei n. } \\
10639 / 03 \text { e seus } \\
\text { delineamentos, buscando } \\
\text { entender as possibilidades } \\
\text { de intervenção para } \\
\text { permanência e sucesso dos } \\
\text { alunos aos negros no } \\
\text { Ensino Fundamental } \\
\text { Público. }\end{array}$ & $\begin{array}{l}\text { Objetivos correlatos: } \\
\text { a) o incentivo aos } \\
\text { professores para } \\
\text { utilizar em seus } \\
\text { planos de ação e em } \\
\text { sua prática } \\
\text { pedagógica, a } \\
\text { História da África e } \\
\text { Cultura Africana, } \\
\text { buscando despertar } \\
\text { nos alunos negros, } \\
\text { autoestima e } \\
\text { reconhecimento de } \\
\text { seu valor na } \\
\text { formação histórica e } \\
\text { cultural do Brasil; b) } \\
\text { a discussão e debate } \\
\text { com o grupo de } \\
\text { professores, por meio } \\
\text { de estratégias } \\
\text { pedagógicas, de } \\
\text { formas de realização } \\
\text { das propostas de } \\
\text { ensino de História e } \\
\text { Cultura Afro- } \\
\text { Brasileira }\end{array}$ & $\begin{array}{l}\text { A resistência dos } \\
\text { professores } \\
\text { dificulta a } \\
\text { implementação da } \\
\text { lei, mas que através } \\
\text { da sensibilização } \\
\text { deles pela temática } \\
\text { o resultado } \\
\text { contribui para } \\
\text { valorização da } \\
\text { contribuição dos } \\
\text { negros para } \\
\text { formação do Brasil. }\end{array}$ & $\begin{array}{l}\text { Foi feita uma } \\
\text { análise documental } \\
\text { da lei e como os } \\
\text { delineamentos da lei } \\
\text { se refletem na } \\
\text { prática escolar. }\end{array}$ \\
\hline
\end{tabular}




\begin{tabular}{|c|c|c|c|c|c|c|}
\hline $\begin{array}{lr}\text { Cultura } & \text { Afro- } \\
\text { brasileira } & \text { e } \\
\text { Educação: } & \text { O } \\
\text { processo } & \text { de } \\
\text { implementação } \\
\text { da } & \text { Lei } \\
\text { 10.639/2003 nas } \\
\text { escolas públicas } \\
\begin{array}{ll}\text { de } & \text { Belo } \\
\text { Horizonte. }\end{array}\end{array}$ & $\begin{array}{l}\text { AVELAR, C. P. R. C; VALENTIM, S. S. } \\
\text { Cultura Afro-brasileira e Educação: O } \\
\text { processo de implementação da Lei } \\
10.639 / 2003 \text { nas escolas públicas de Belo } \\
\text { Horizonte. } 4^{\circ} \text { SENEPT - Seminário nacional } \\
\text { de Educação Profissional e Tecnológica, } \\
2010 \text {. } \\
\text { Disponível em } \\
\text { <http://www.senept.cefetmg.br/galerias/Ana } \\
\text { is_2010/Artigos/GT9/CULTURA_AFRO- } \\
\text { BRASILEIRA.pdf >. Acesso em: fevereiro, } \\
\text { 2016. }\end{array}$ & $\begin{array}{lr}\text { Educação das } & \text { Relações } \\
\text { Étnicorraciais; } & \text { Lei } \\
10.639 / 2003 ; & \\
\text { Diversidade } & \\
\text { Étnicorracial. } & \end{array}$ & $\begin{array}{l}\text { A publicação da Lei } \\
\text { Federal 10.639/2003 } \\
\text { tornou obrigatório o ensino } \\
\text { da temática História e } \\
\text { Cultura Afro-brasileira nos } \\
\text { estabelecimentos de ensino } \\
\text { fundamental e médio das } \\
\text { redes pública e particular } \\
\text { do país. Este artigo propõe } \\
\text { analisar, a partir do } \\
\text { trabalho desenvolvido pelo } \\
\text { Núcleo de Relações } \\
\text { Étnicorraciais e de Gênero } \\
\text { da Secretaria Municipal de } \\
\text { Educação de Belo } \\
\text { Horizonte, quais são as } \\
\text { possibilidades e os } \\
\text { desafios que os espaços } \\
\text { escolares públicos } \\
\text { municipais da capital } \\
\text { mineira oferecem para } \\
\text { acolher a implementação } \\
\text { da Lei 10639/2003. } \\
\text { Portanto, fazemos uma } \\
\text { breve reflexão acerca da } \\
\text { dinâmica do cotidiano } \\
\text { escolar no que tange às } \\
\text { questões étnicorraciais. }\end{array}$ & 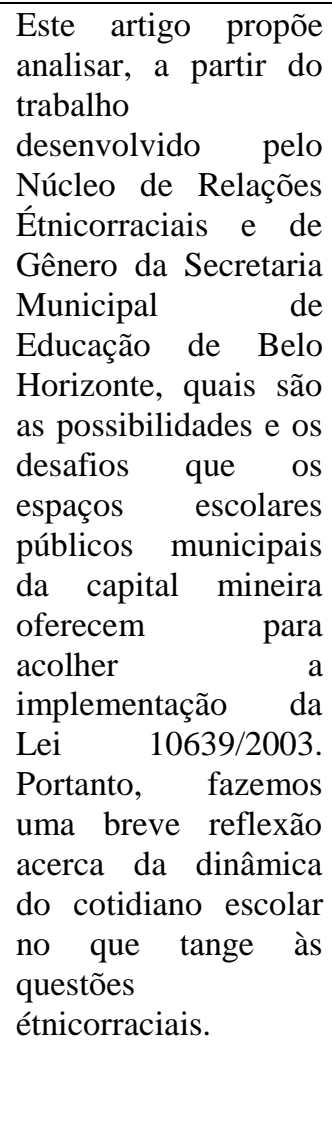 & $\begin{array}{l}\text { Brasil não é um } \\
\text { país de relações } \\
\text { raciais } \\
\text { harmoniosas. } \\
\text { Considerando-se } \\
\text { nossa sociedade } \\
\text { multirracial e } \\
\text { multiétnica, } \\
\text { profundamente } \\
\text { marcada por } \\
\text { desigualdades e } \\
\text { contradições neste } \\
\text { contexto, a escola é } \\
\text { eleita como locus } \\
\text { privilegiado para } \\
\text { agenciar alterações } \\
\text { nessa realidade. }\end{array}$ & $\begin{array}{l}\text { A pesquisa tem } \\
\text { como referência } \\
\text { metodológica um } \\
\text { estudo bibliográfico } \\
\text { e análise } \\
\text { documental. }\end{array}$ \\
\hline
\end{tabular}




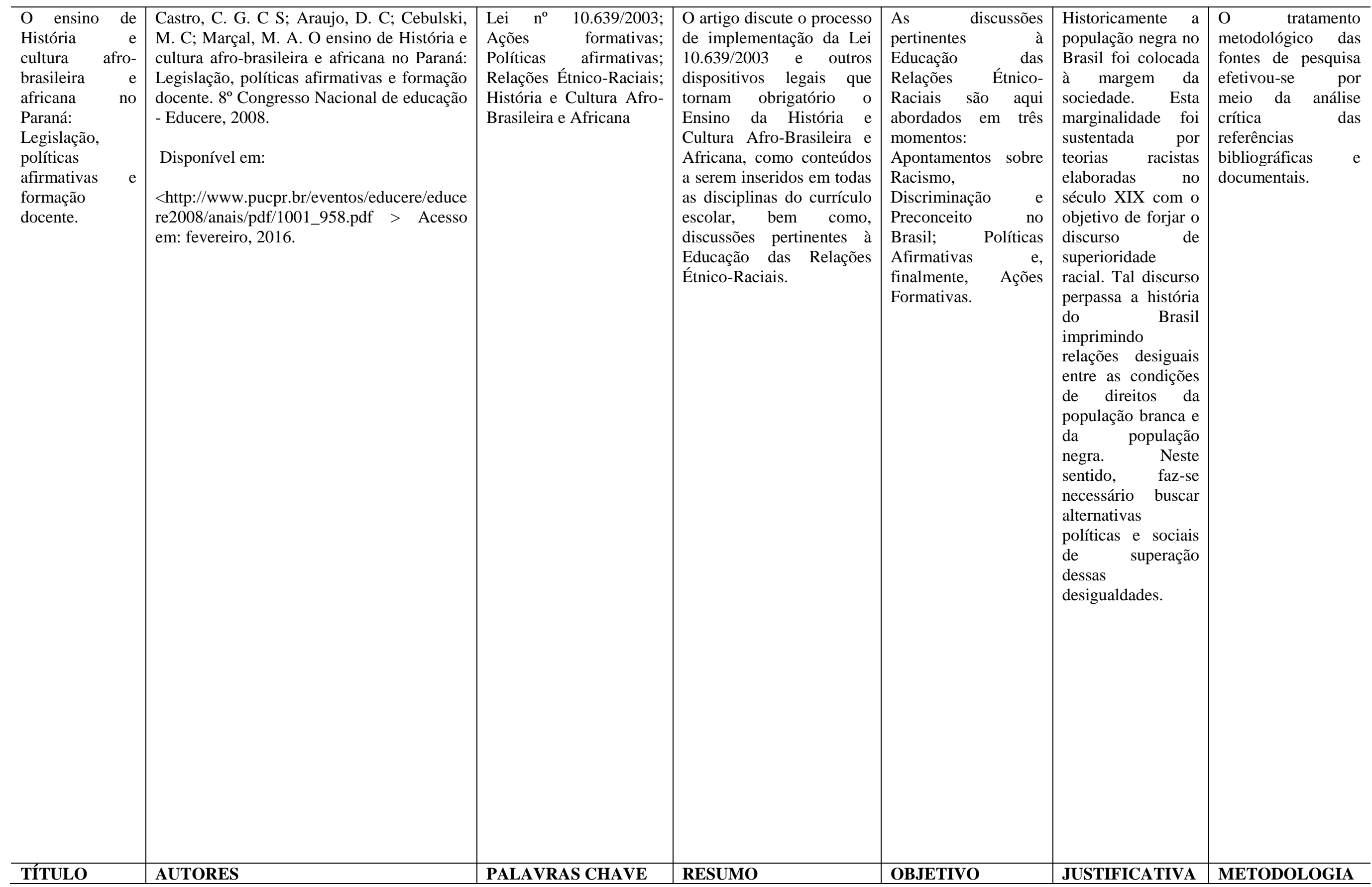


10 anos da lei Benjamin Xavier, B. P; Guimarães, S. $10 \mid$ Ensino - História da federal

\section{$\mathrm{n}^{\mathrm{o}}$}

$10.639 / 2003$ e a

formação professores: uma leitura de

pesquisas científicas Paulo, v. 40, n. 2, p. 435-448, abr./jun. 2014. formação de professores: uma leitura de

pesquisas científicas. Educ. Pesquisa, São

Disponível em

$<$ http://www.scielo.br/scielo.php?script=sci arttext\&pid=S1517-97022014000200009 > Acesso em: fevereiro, 2016.

África - Formação de

professo

O estudo aborda a formação de professores com implementação da História e Cultura da África e Afro-brasileira, conforme dispõe a lei federal $n^{\circ} 10.639 / 2003$ e as disposições correlatas. Faz parte de uma pesquisa mais ampla cuja opção metodológica ampara-se na abordagem defendida por Canen (2008). Nessa concepção, entende-se o multiculturalismo como conceito e prática estruturante na pesquisa científica em educação e na formação professores, bem como na pluralidade paradigmática como eixo teóricometodológico para essas pesquisas.
$\mathrm{O}$ texto tem por objetivo elencar e analisar o estado da arte na perspectiva defendida Ferreira (2002)

André; Romanowski (1999); e a pesquisa bibliográfica,

conforme disposto em Gil (2002) e Lima; Mioto (2007). Nossas fontes de investigac̃a relatório de pesquisa, consolidado a partir do banco de teses e dissertações

Fundação

Coordenação de Aperfeiçoamento de Pessoal de Nível Superior (CAPES) sobre a produção de teses de doutorado e dissertações mestrado; e relatório de consolidado a parti do banco de artigo científicos constantes na base da Scientific Electronic Library Online (SCIELO).
As pesquisas apontam para uma invisibilidade do tema nos anos anteriores à década que começa no ano 2000.

investigação respeito do esta da arte nas pesquisas sobre formação professores,

realizadas nos anos de 1980 e 1990 não evidencia essa temática. O tema não é visível até década de 1990 para as instituições de educação e pesquisa, em especial aquelas votadas para a formação dos professores para a educação básica e para o ensino superior; na década de 2000, torna-se um dos temas com crescente demanda e inserção no campo da pesquisa, do ensino e da extensão.
O tratamento metodológico das fontes de pesquisa efetivou-se por meio da análise crítica das

referências

bibliográficas

documentais. 


\begin{tabular}{|c|c|c|c|c|c|c|}
\hline $\begin{array}{l}\text { Cumpra-se a lei: } \\
\text { um estudo dos } \\
\text { processos contra } \\
\text { as escolas que } \\
\text { não } \\
\text { implantaram a } \\
\text { Lei } 10.639 \text { de } \\
2003\end{array}$ & $\begin{array}{l}\text { Freitas, L. F. Cumpra-se a lei: um estudo dos } \\
\text { processos contra as escolas que não } \\
\text { implantaram a Lei 10.639 de 2003. 26 } 6^{\mathrm{a}} \\
\text { Reunião Brasileira de Antropologia, junho - } \\
\text { 2009, Porto Seguro, Bahia, Brasil. } \\
\text { Disponível em: } \\
\text { <http://www.abant.org.br/conteudo/ANAIS/ } \\
\text { CD_Virtual_26_RBA/grupos_de_trabalho/tr } \\
\text { abalhos/GT\%2008/ludmila\%20fernandes\%2 } \\
\text { Ode\%20freitas.pdf > Acesso em: fevereiro, } \\
\text { 2016. }\end{array}$ & $\begin{array}{l}\text { Políticas Públicas, Ações } \\
\text { Afirmativas, "Raça". }\end{array}$ & $\begin{array}{l}\text { Pretende-se compreender } \\
\text { as consequências da } \\
\text { implantação da Lei } \\
10.639 / 2003 \text {. Pretendo } \\
\text { analisar o percurso e os } \\
\text { impactos dessa política } \\
\text { pública em primeiro lugar } \\
\text { no que se refere aos novos } \\
\text { parâmetros de construção } \\
\text { de hierarquias com base na } \\
\text { "raça". }\end{array}$ & $\begin{array}{l}\text { O objetivo do texto é } \\
\text { analisar o percurso e } \\
\text { os impactos dessa } \\
\text { política pública em } \\
\text { primeiro lugar no que } \\
\text { se refere aos novos } \\
\text { parâmetros de } \\
\text { construção de de } \\
\text { hierarquias com base } \\
\text { na "raça". Pretendo } \\
\text { também compreender } \\
\text { quais as formas de } \\
\text { implantação dessa } \\
\text { Lei pelo Estado e } \\
\text { como ela compõe o } \\
\text { novo cenário das } \\
\text { relações raciais } \\
\text { brasileiras. Para tanto } \\
\text { analisarei as ações do } \\
\text { Ministério Público } \\
\text { Federal em relação às } \\
\text { escolas que não estão } \\
\text { cumprindo as a a } \\
\text { exigências da Lei } \\
10.639 / 2003 \text {. }\end{array}$ & $\begin{array}{l}\text { A Lei } 10.639 / 2003 \\
\text { relaciona-se às } \\
\text { novas orientações } \\
\text { assumida pelo } \\
\text { Estado brasileiro } \\
\text { em relação às } \\
\text { políticas públicas. } \\
\text { Após 2001, o } \\
\text { Governo Brasileiro } \\
\text { incorporou "a } \\
\text { categoria "raça"2 } \\
\text { na definição dos } \\
\text { critérios de } \\
\text { distribuição de } \\
\text { direitos sociais, } \\
\text { inaugurando uma } \\
\text { classificação } \\
\text { racializada nas } \\
\text { ações burocráticas } \\
\text { e jurídicas. }\end{array}$ & $\begin{array}{l}\text { Tem como } \\
\text { referência } \\
\text { metodológica um } \\
\text { estudo bibliográfico } \\
\text { e análise } \\
\text { documental. }\end{array}$ \\
\hline
\end{tabular}




\begin{tabular}{|c|c|c|c|c|c|c|}
\hline $\begin{array}{l}\text { A cultura afro- } \\
\text { brasileira e um } \\
\text { possível diálogo } \\
\text { com a lei } \\
\text { 10.639/2003: } \\
\text { diretrizes e } \\
\text { práticas }\end{array}$ & $\begin{array}{l}\text { Thiago Silveira de Melo, T. S; Apolinário, J. } \\
\text { R. A cultura afro-brasileira e um possível } \\
\text { diálogo com a lei 10.639/2003: diretrizes e } \\
\text { práticas. IX Seminário Nacional de Estudos } \\
\text { e Pesquisas "História, Sociedade e Educação } \\
\text { no Brasil" Universidade Federal da Paraíba } \\
\text { - João Pessoa - 31/07 a 03/08/2012 - Anais } \\
\text { Eletrônicos, 2012. } \\
\text { Disponível em } \\
\text { <http://www.histedbr.fe.unicamp.br/acer_his } \\
\text { tedbr/seminario/seminario9/PDFs/5.10.pdf > } \\
\text {. Acesso em: fevereiro, 2016 }\end{array}$ & $\begin{array}{ll}\text { Livro didático. } & \text { Cultura } \\
\text { Afro-brasileira. } & \\
\text { Representação } & \end{array}$ & $\begin{array}{l}\text { Trata-se de um estudo da } \\
\text { aplicabilidade da Lei } \\
10.639 / 2003 \text {, na Escola } \\
\text { Normal Estadual Padre } \\
\text { Emídio Viana Correia, } \\
\text { através de um esboço } \\
\text { sobre as características da } \\
\text { escola, bem como dos } \\
\text { materiais fomentadores do } \\
\text { conhecimento histórico, } \\
\text { adotado pelos docentes da } \\
\text { mesma, haja vista que sua } \\
\text { modalidade é responsável } \\
\text { por formar docentes para o } \\
\text { magistério, responsáveis } \\
\text { pelo ensino básico. }\end{array}$ & $\begin{array}{l}\text { Na perspectiva de } \\
\text { fazermos um diálogo } \\
\text { com o saber histórico } \\
\text { e compreendermos } \\
\text { como o ensino da } \\
\text { cultura afro-brasileira } \\
\text { é visibilizado nos } \\
\text { conteúdos deste } \\
\text { camporar do } \\
\text { conhecimento, no } \\
\text { nível médio, é que } \\
\text { propomos, a partir de } \\
\text { pesquisa realizada na } \\
\text { Escola Normal } \\
\text { Estadual Padre } \\
\text { Emídio Viana } \\
\text { Correia, lócus deste } \\
\text { estudo, identificar, } \\
\text { como este segmento } \\
\text { étnico-cultural está } \\
\text { sendo discutido no } \\
\text { campo historiográfico }\end{array}$ & $\begin{array}{l}\text { Tendo em vista que } \\
\text { no cotidiano dos } \\
\text { fazeres escolares, } \\
\text { os docentes e os/as } \\
\text { alunos/as sas são } \\
\text { sujeitos históricos } \\
\text { importantes na na } \\
\text { elaboração de uma } \\
\text { nova forma de } \\
\text { pensar e } \\
\text { representar } \\
\text { cultura } \\
\text { afro-brasileira no } \\
\text { contexto } \\
\text { educaçãa, en da } \\
\text { particular no ensino } \\
\text { da História, } \\
\text { torna-se necessária } \\
\text { a verificação de } \\
\text { como, através do } \\
\text { livro didático, os } \\
\text { indivíduos } \\
\text { observam } \\
\text { aplicabilidade da } \\
\text { Lei 10.639/2003, } \\
\text { bem como de que } \\
\text { forma eles se } \\
\text { relacionam e se } \\
\text { identificam com a } \\
\text { cultura e história } \\
\text { afro-brasileira. }\end{array}$ & $\begin{array}{l}\text { empregou-se como } \\
\text { recurso } \\
\text { metodológico a } \\
\text { pesquisa de campo, } \\
\text { o estudo } \\
\text { bibliográfico } \\
\text { análise documental. }\end{array}$ \\
\hline
\end{tabular}




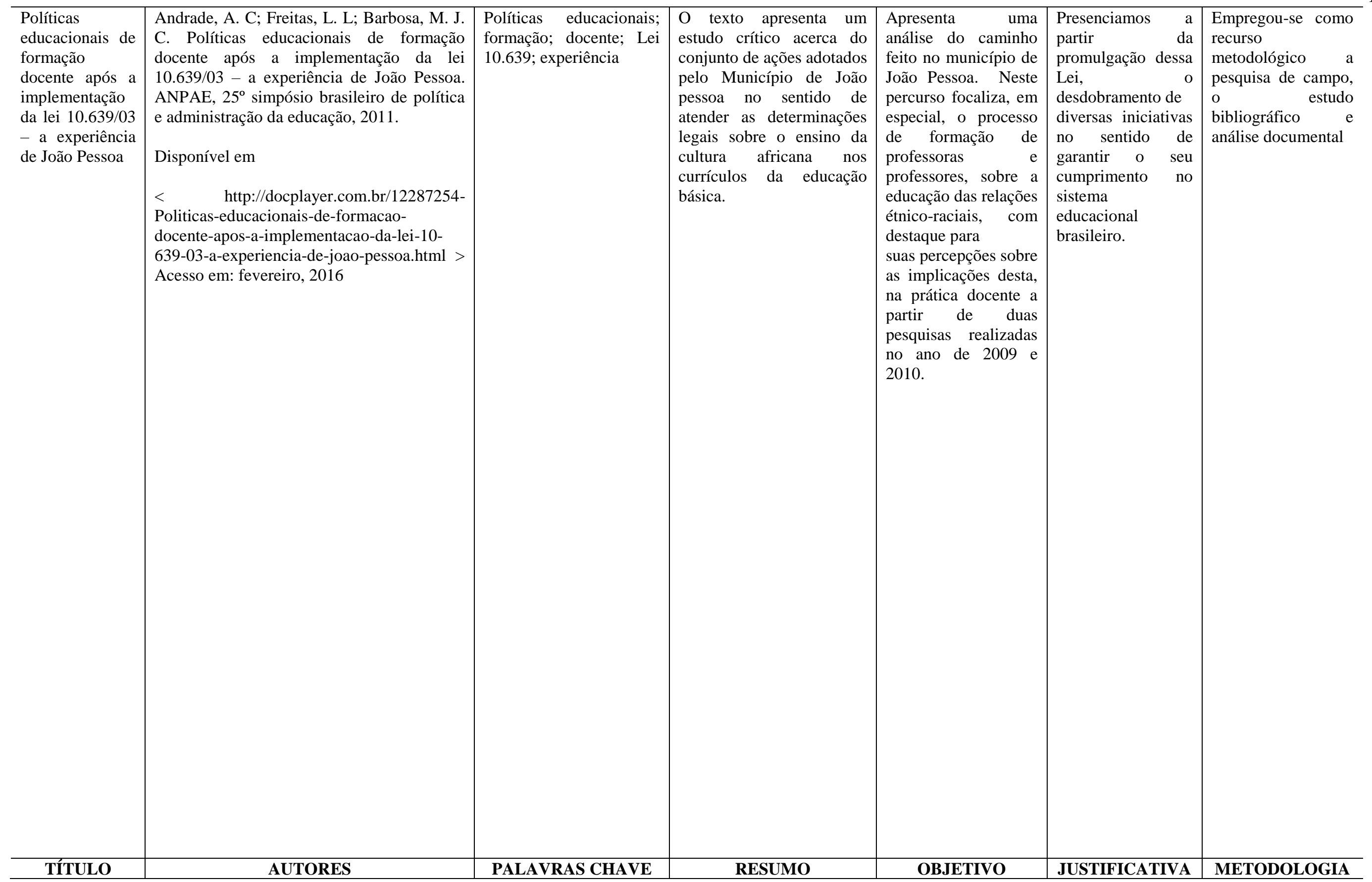




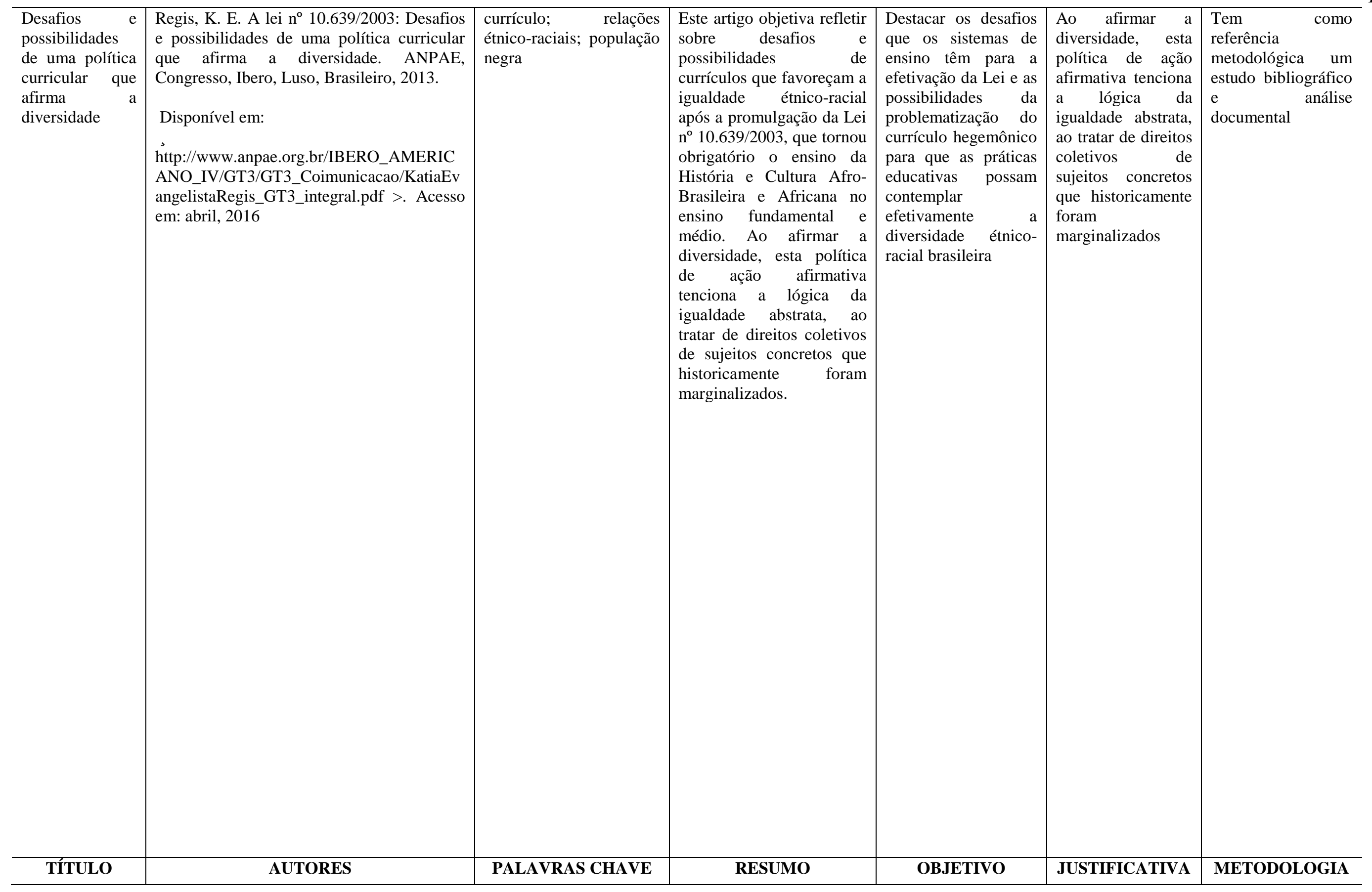




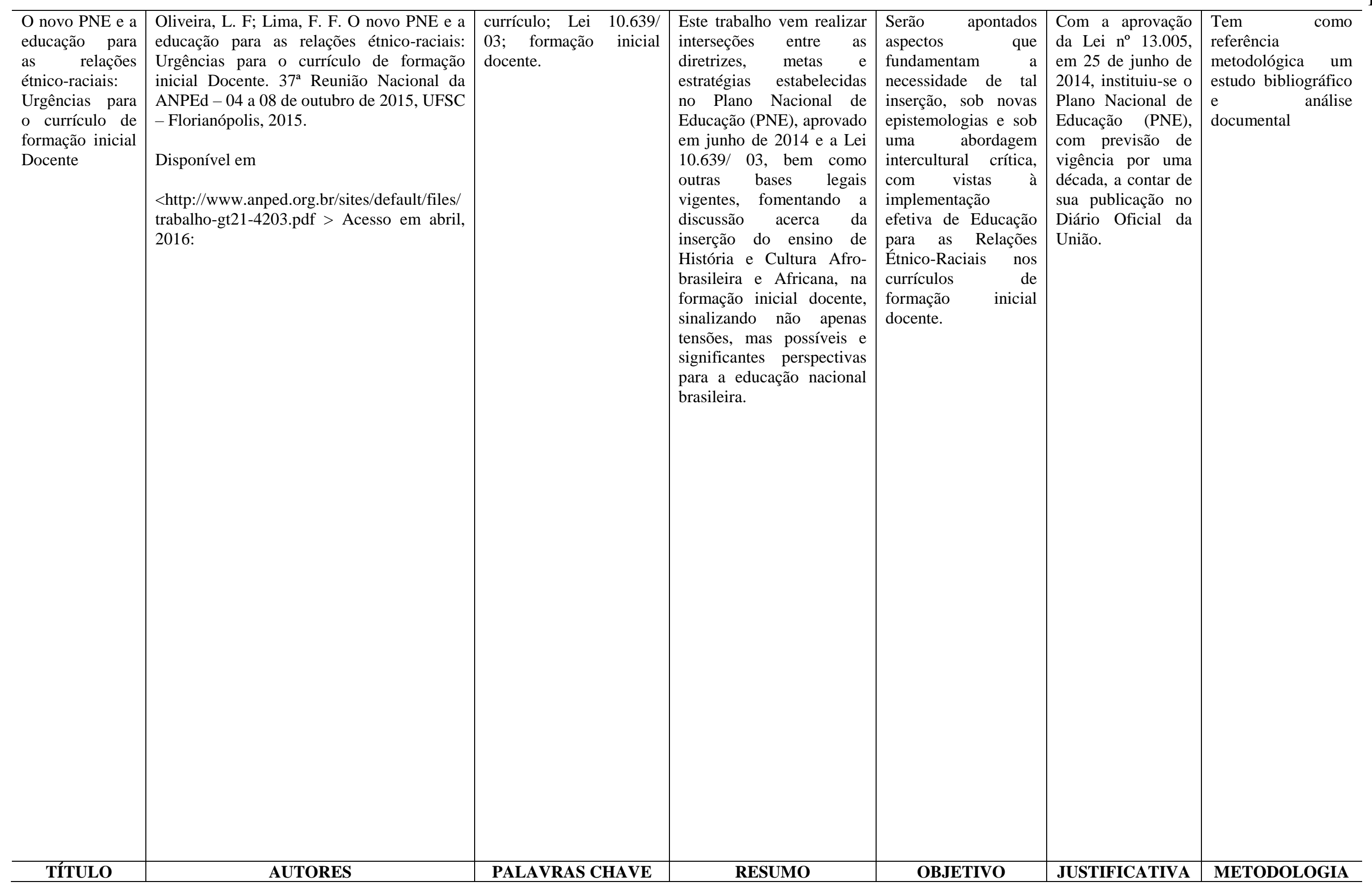




\begin{tabular}{|c|c|c|c|c|c|c|}
\hline $\begin{array}{l}\text { A luz da lei } \\
\text { 10.639/2003: } \\
\text { movimentos } \\
\text { sociais negros, } \\
\text { legislação } \\
\text { educacional e } \\
\text { experiências } \\
\text { pedagógicas }\end{array}$ & $\begin{array}{l}\text { Rocha, S.; Silva, J. A. N. A luz da lei } \\
\text { 10.639/2003: movimentos sociais negros, } \\
\text { legislação educacional e experiências } \\
\text { pedagógicas. Revista da ABPN • v. 5, n. 11 } \\
\text { jul.- out. } 2013 \cdot \text { p. 55-82. } \\
\text { Disponível em: } \\
\text { <http://www.abpn.org.br/Revista/index.php/ } \\
\text { edicoes/article/viewFile/399/284 >. Acesso } \\
\text { em: fevereiro, } 2016\end{array}$ & $\begin{array}{l}\text { Lei } 10.639 / 2003 \\
\text { Movimento Sociais, } \\
\text { Legislação. educação }\end{array}$ & 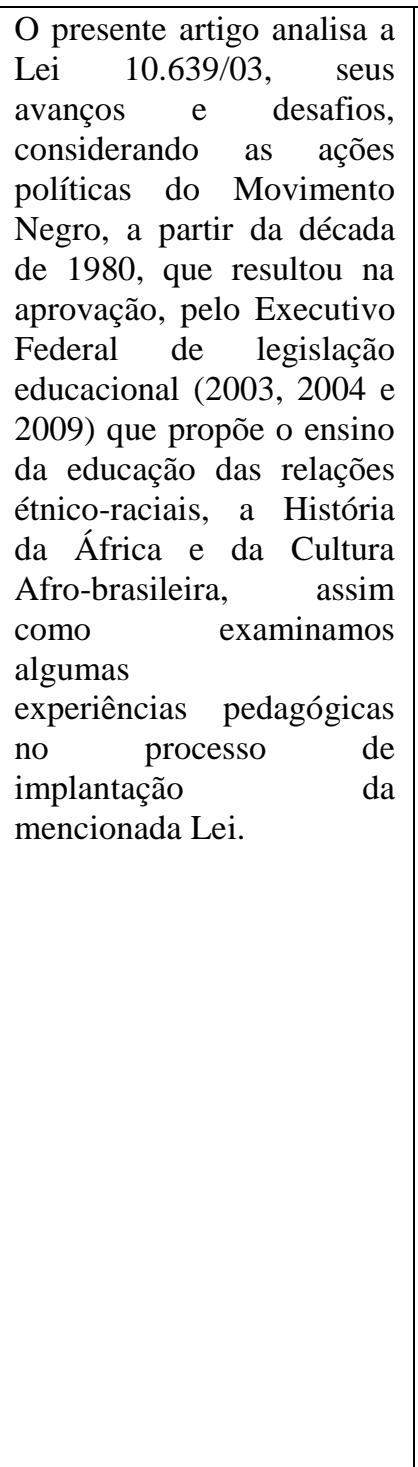 & 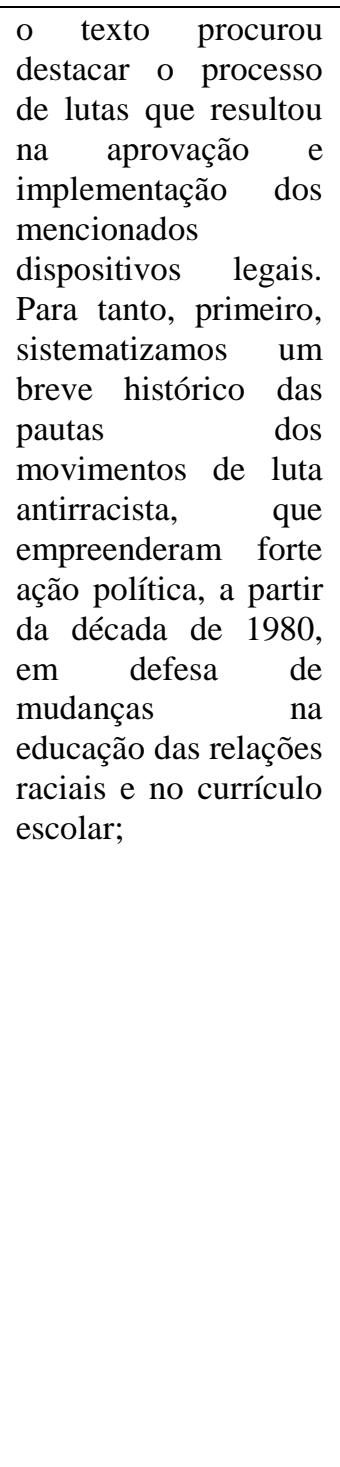 & 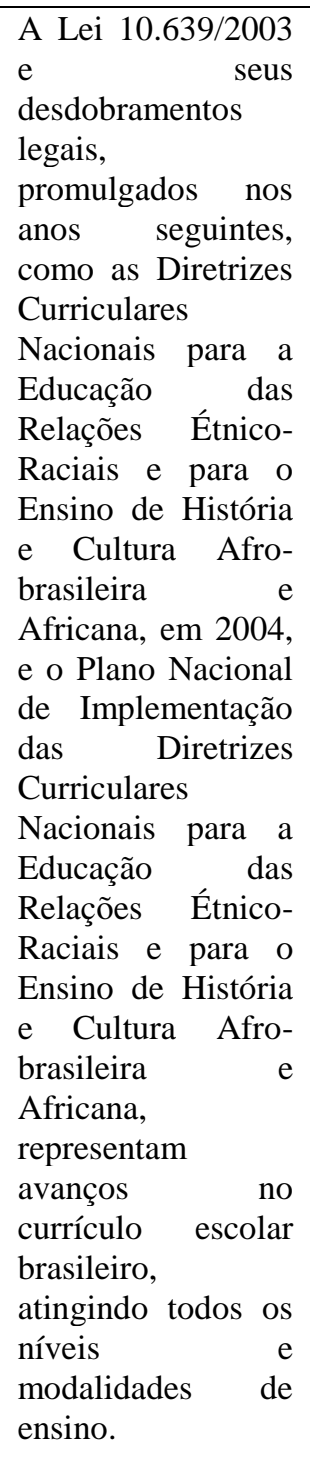 & $\begin{array}{l}\text { A pesquisa tem } \\
\text { como referência } \\
\text { metodológica um } \\
\text { estudo bibliográfico } \\
\text { e r análise } \\
\text { documental. }\end{array}$ \\
\hline TÍTULO & AUTORES & PALAVRAS CHAVE & RESUMO & OBJETIVO & JUSTIFICATIVA & METODOLOGIA \\
\hline
\end{tabular}




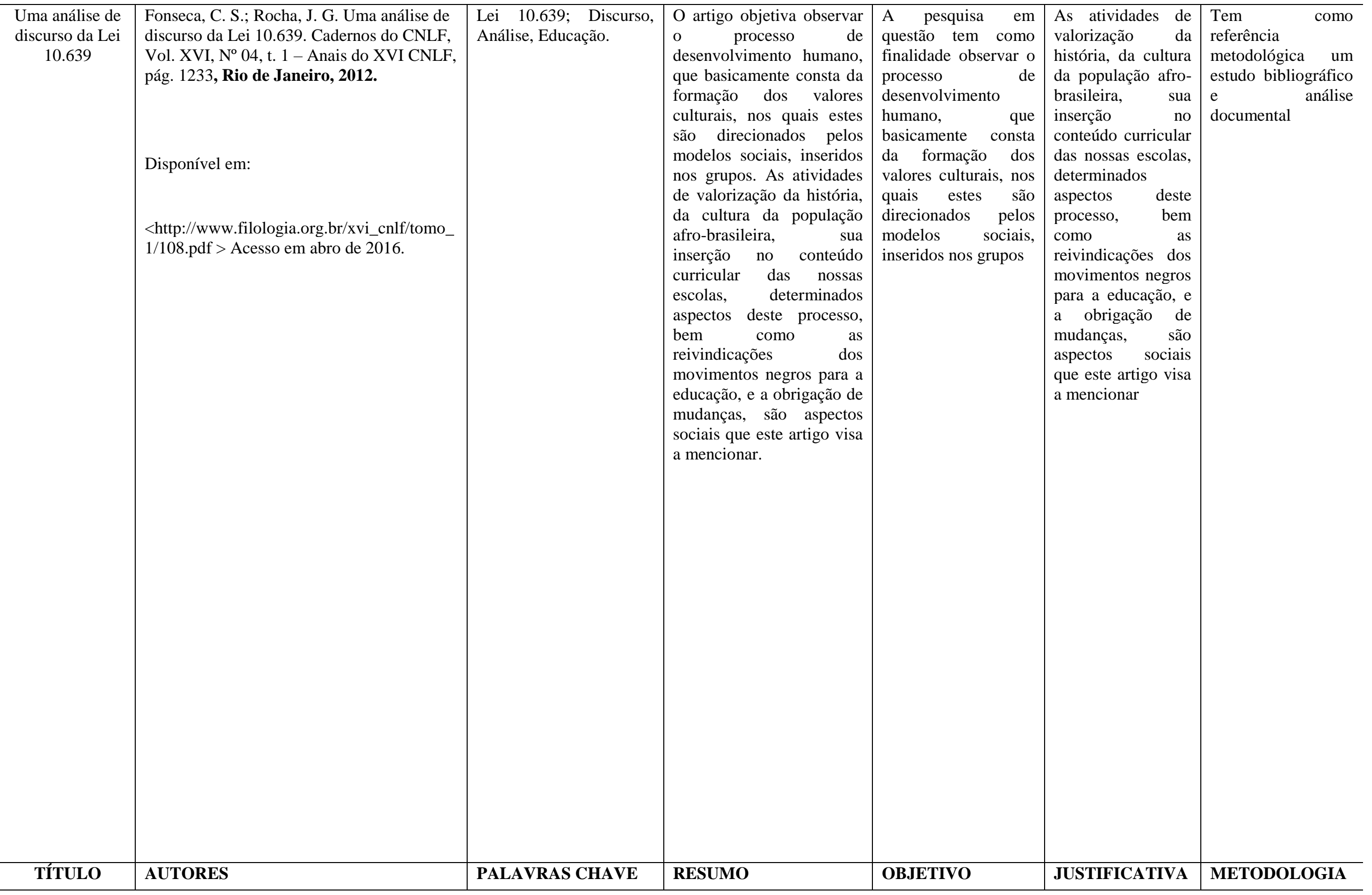




\begin{tabular}{|c|c|c|c|c|c|c|}
\hline $\begin{array}{l}\text { Igualdade ou } \\
\text { reparação? Uma } \\
\text { releitura } \\
\text { histórica da Lei } \\
10.639 / 20013\end{array}$ & $\begin{array}{l}\text { Moraes, G. K. Igualdade ou reparação? Uma } \\
\text { releitura histórica da Lei 10.639/20013. } \\
\text { Universidade de Sorocaba, Sorocaba, } 2015 \text {. } \\
\text { Disponível em: } \\
\text { http://educacao.sorocaba.sp.gov.br/wp- } \\
\text { content/uploads/2015/03/IgualdadeouRepara } \\
\text { cao.pdf >. Acesso em abri, 2016. }\end{array}$ & $\begin{array}{l}\text { História e Cultura afro } \\
\text { Brasileira e Africana; } \\
\text { Políticas Afirmativas; } \\
\text { Movimento Negro }\end{array}$ & $\begin{array}{l}\text { Este presente artigo expõe } \\
\text { investigação do processo } \\
\text { de tramitação da Lei } \\
10.639 / 03 \text { que instituiu a } \\
\text { obrigatoriedade da } \\
\text { inclusão, entre outras } \\
\text { temáticas, da "História e } \\
\text { Cultura afro-Brasileira e } \\
\text { Africana" no currículo } \\
\text { oficial da Rede de Ensino } \\
\text { de Educação Básica. Teve } \\
\text { como eixo norteador as } \\
\text { seguintes questões: A } \\
\text { origem da ideia de uma } \\
\text { política de reparação e } \\
\text { afirmação para os } \\
\text { afrodescendentes no } \\
\text { Brasil; quais foram às } \\
\text { forças que influenciaram } \\
\text { na elaboração da Lei; } \\
\text { atende às expectativas de } \\
\text { quais setores da sociedade; } \\
\text { quais políticos } \\
\text { manifestaram-se } \\
\text { favoravelmente e quais } \\
\text { conceitos defenderam; em } \\
\text { que momento essa Lei } \\
\text { surgiu; quais expectativas } \\
\text { havia em torno da Lei? }\end{array}$ & 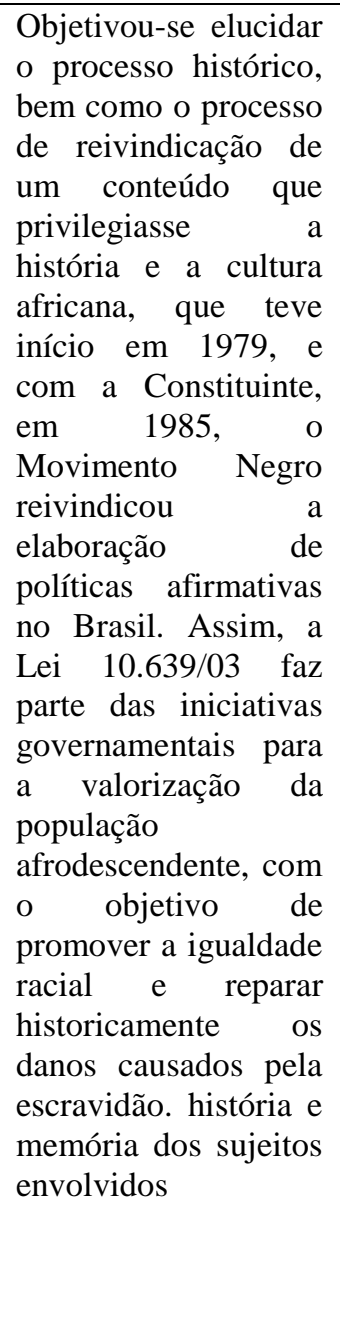 & $\begin{array}{l}\text { A origem da ideia } \\
\text { de uma política de } \\
\text { reparação } \\
\text { afirmação para os } \\
\text { afrodescendentes } \\
\text { no Brasil; quais } \\
\text { foram às forças que } \\
\text { influenciaram na } \\
\text { elaboração da Lei; } \\
\text { atende à } \\
\text { expectativas de } \\
\text { quais setores da } \\
\text { sociedade; quais } \\
\text { políticos } \\
\text { manifestaram-se } \\
\text { favoravelmente e } \\
\text { quais conceitos } \\
\text { defenderam; em } \\
\text { que momento essa } \\
\text { Lei surgiu; quais } \\
\text { expectativas havia } \\
\text { em torno da Lei? } \\
\text { Essas questões e as } \\
\text { fontes documentais } \\
\text { e } \\
\text { possibilitaram orais a } \\
\text { reconstrução do } \\
\text { processo de luta do } \\
\text { Movimento Negro } \\
\text { e a reflexão sobre } \\
\text { história e memória } \\
\text { dos sujeitos } \\
\text { envolvidos }\end{array}$ & $\begin{array}{l}\text { Estudo bibliográfico } \\
\mathrm{e} \quad \text { análise } \\
\text { documental. }\end{array}$ \\
\hline
\end{tabular}




\begin{tabular}{|c|c|c|c|c|c|c|}
\hline 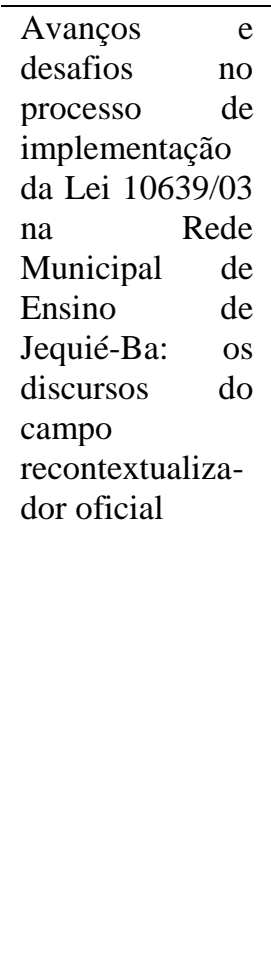 & $\begin{array}{l}\text { Souza, J. B; Santos. J. J. R; Eugêni, B. G. } \\
\text { Avanços e desafios no processo de } \\
\text { implementação da Lei } 10639 / 03 \text { na Rede } \\
\text { Municipal de Ensino de Jequié-Ba: os } \\
\text { discursos do campo recontextualizador } \\
\text { oficial. Revista Práxis Educacional, Vitória } \\
\text { da Conquista. v. 11, n. 18 p. 177-197 } \\
\text { jan./abr. 2015. } \\
\text { Disponível em: } \\
\text { http://periodicos.uesb.br/index.php/praxis/art } \\
\text { icle/viewFile/4708/4493 >. Acesso em abril, } \\
\text { 2016. }\end{array}$ & $\begin{array}{l}\text { Discurso pedagógico. Lei } \\
10639 / 03 . \quad \text { Relações } \\
\text { etnicorraciais. }\end{array}$ & $\begin{array}{l}\text { A Lei } 10639 / 03 \text {, entendida } \\
\text { como uma política de ação } \\
\text { afirmativa, trouxe para os } \\
\text { sistemas de ensino novas } \\
\text { demandas para serem } \\
\text { inseridas no currículo. } \\
\text { Neste artigo, abordamos o } \\
\text { discurso pedagógico das } \\
\text { gestoras acerca dos } \\
\text { desafios e avanços no } \\
\text { processo de discussão e } \\
\text { implementação da Lei } \\
\text { 10639/03 na Rede } \\
\text { Municipal de Educação de } \\
\text { Jequié-Ba. Os dados foram } \\
\text { construídos a partir de } \\
\text { entrevistas realizadas com } \\
\text { três funcionárias da } \\
\text { Secretaria Municipal de } \\
\text { Educação e Cultura que } \\
\text { acompanharam, em } \\
\text { diferentes momentos, a } \\
\text { política de educar para as } \\
\text { relações etnicorraciais. }\end{array}$ & $\begin{array}{l}\text { A Lei } 10639 / 03, \\
\text { entendida como uma } \\
\text { política de ação } \\
\text { afirmativa, trouxe } \\
\text { para os sistemas de } \\
\text { ensino novas } \\
\text { demandas para serem } \\
\text { inseridas no currículo }\end{array}$ & $\begin{array}{lr}\text { A Lei } & 10639 / 03, \\
\text { entendida como } \\
\text { uma política de } \\
\text { ação } & \text { afirmativa, } \\
\text { trouxe para os } \\
\text { sistemas } & \text { de ensino } \\
\text { novas } & \text { demandas } \\
\text { para } & \text { serem } \\
\text { inseridas } & \text { no } \\
\text { currículo } & \end{array}$ & $\begin{array}{l}\text { Os dados foram } \\
\text { construídos a partir } \\
\text { de entrevistas } \\
\text { realizadas com três } \\
\text { funcionárias da } \\
\text { Secretaria } \\
\text { Municipal de } \\
\text { Educação e Cultura } \\
\text { que acompanharam, } \\
\text { em diferentes } \\
\text { momentos, a } \\
\text { política de educar } \\
\text { para as relações } \\
\text { etnicorraciais. }\end{array}$ \\
\hline
\end{tabular}


ANEXO 5 -LEVANTAMENTO DE DISSERTAÇÕES

\begin{tabular}{|c|c|c|c|c|c|c|c|c|c|}
\hline TÍTULO & AUTORES & LOCAL & TIPO & ANO & $\begin{array}{c}\text { PALAVRAS } \\
\text { CHAVE }\end{array}$ & RESUMO & OBJETIVO & JUSTIFICATIVA & METODOLOGIA \\
\hline $\begin{array}{l}\text { Educação das } \\
\text { relações étnico- } \\
\text { raciais: } \\
\text { contribuições de } \\
\text { cursos de } \\
\text { formação } \\
\text { continuada para } \\
\text { professoras(es). }\end{array}$ & 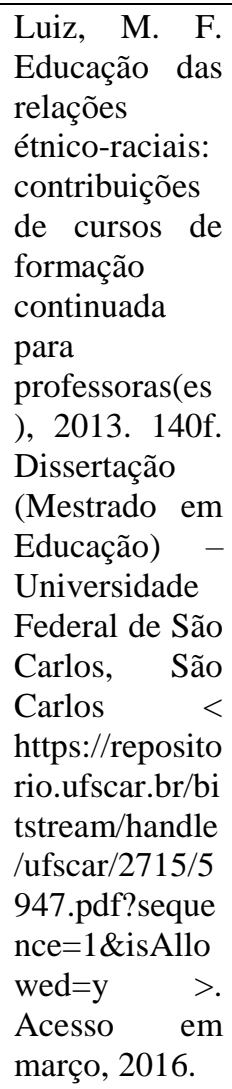 & $\begin{array}{l}\text { Universi } \\
\text { dade } \\
\text { Federal } \\
\text { de São } \\
\text { Carlos. }\end{array}$ & Dissertação & 2013 & $\begin{array}{l}\text { Práticas } \\
\text { pedagógicas. } \\
\text { Processo } \\
\text { educativo. } \\
\text { Formação } \\
\text { continuada de } \\
\text { professores(as } \\
\text { ). } \\
\text { Educação das } \\
\text { relaçôes } \\
\text { étnico-raciais. }\end{array}$ & $\begin{array}{l}\text { A presente } \\
\text { pesquisa } \\
\text { investiga as } \\
\text { contribuições } \\
\text { para mudanças } \\
\text { (ou não) nas } \\
\text { práticas } \\
\text { pedagógicas de } \\
\text { professoras(es) } \\
\text { dos anos iniciais } \\
\text { do ensino } \\
\text { fundamental } \\
\text { advindas dos } \\
\text { processos } \\
\text { educativos } \\
\text { desencadeados } \\
\text { nos cursos de } \\
\text { formação } \\
\text { referentes a } \\
\text { temática étnico- } \\
\text { racial. }\end{array}$ & $\begin{array}{l}\text { Possibilidade de reflexão } \\
\text { sobre pontos que em cursos } \\
\text { de formação continuada } \\
\text { contribuíram, ou não, para } \\
\text { mudança da prática dessas } \\
\text { professoras, questões que } \\
\text { precisam ser repensadas na } \\
\text { formulação de futuros } \\
\text { cursos, bem como a } \\
\text { influência de questões } \\
\text { subjetivas referentes às } \\
\text { vivências de professoras(es) } \\
\text { e que influenciam na } \\
\text { compreensão e adesão da } \\
\text { temática. }\end{array}$ & $\begin{array}{l}\text { A partir } \quad \text { da } \\
\text { implementação da lei } \\
\text { 10.639/031, os temas } \\
\text { referentes à História e } \\
\text { Cultura afro-brasileira e } \\
\text { africana tornaram-se } \\
\text { obrigatórios no currículo } \\
\text { escolar das redes públicas } \\
\text { e particulares, o que cria } \\
\text { demanda para realização } \\
\text { de cursos de formação } \\
\text { continuada para docentes } \\
\text { dos diferentes níveis de } \\
\text { ensino atuantes nestes } \\
\text { sistemas. }\end{array}$ & $\begin{array}{l}\text { Pesquisa de campo } \\
\mathrm{e} \\
\text { documental. }\end{array}$ \\
\hline
\end{tabular}




\begin{tabular}{|c|c|c|c|c|c|c|c|c|c|}
\hline TÍTULO & AUTORES & LOCAL & TIPO & ANO & $\begin{array}{c}\text { PALAVRAS } \\
\text { CHAVE }\end{array}$ & RESUMO & OBJETIVO & JUSTIFICATIVA & METODOLOGIA \\
\hline $\begin{array}{ll}\text { A imagem do } & \text { degro em } \\
\text { negro } & \text { manuais para o } \\
\text { professor: uma } \\
\text { análise } \\
\text { linguístico- } \\
\text { discursiva } \\
\text { ideológica. }\end{array}$ & 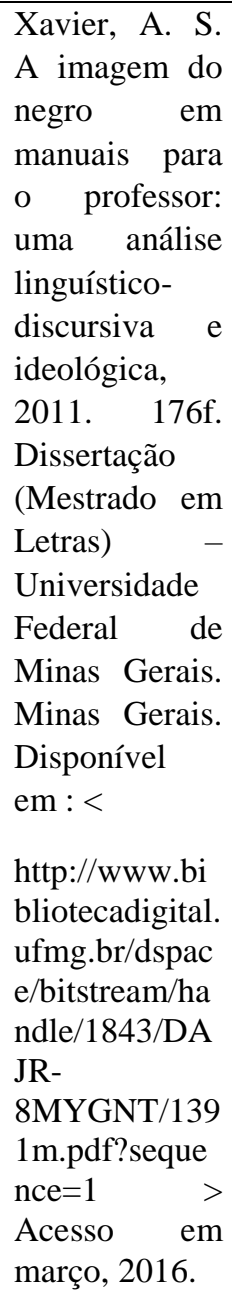 & UFMG & Dissertação & 2011 & $\begin{array}{l}\text { Linguística. } \\
\text { Discurso. } \\
\text { Negros. } \\
\text { Educação. } \\
\text { Professores. } \\
\text { Formação. } \\
\text { Racismo. }\end{array}$ & $\begin{array}{l}\text { No presente } \\
\text { estudo, visamos } \\
\text { investigar como } \\
\text { se constrói, } \\
\text { linguística e } \\
\text { discursivamente, } \\
\text { a imagem do } \\
\text { negro em dois } \\
\text { livros destinados } \\
\text { a professores que } \\
\text { pertencem, } \\
\text { respectivamente, } \\
\text { ao II e ao IV Kit } \\
\text { de Literatura } \\
\text { Afro-brasileira, } \\
\text { elaborados pela } \\
\text { rede municipal de } \\
\text { ensino de Belo } \\
\text { Horizonte/MG, } \\
\text { em cumprimento } \\
\text { à Lei n }{ }^{\circ} \\
\text { 10.639/03. }\end{array}$ & $\begin{array}{l}\text { Visamos investigar como se } \\
\text { constrói, linguística e } \\
\text { discursivamente, a imagem } \\
\text { do negro em dois livros } \\
\text { destinados a professores que } \\
\text { pertencem, respectivamente, } \\
\text { ao II e ao IV Kit de } \\
\text { Literatura Afro-brasileira, } \\
\text { elaborados pela rede } \\
\text { municipal de ensino de Belo } \\
\text { Horizonte/MG, è } \\
\text { cumprimento à Lei no } \\
\text { 10.639/03 - Bonecas negras, } \\
\text { cadê? O negro no currículo } \\
\text { escolar: sugestões práticas, } \\
\text { de Maria Zilá Teixeira de } \\
\text { Matos (2004); e e } \\
\text { Africanidade } \\
\text { afrobrasilidade: orientações } \\
\text { metodológicas para a } \\
\text { implementação da lei } \\
\text { 10.639/03. }\end{array}$ & $\begin{array}{l}\text { Busca-se o novo papel do } \\
\text { professor com as } \\
\text { mudanças trazidas com a } \\
\text { lei } \mathrm{n}^{\circ} 10.639 / 2003 \text {, se } \\
\text { para Matos (2004), antes } \\
\text { o professor cumpre o } \\
\text { papel de reprodutor da } \\
\text { dinâmica social } \\
\text { excludente } \\
\text { discriminatória, em } \\
\text { Arruda (2009), ele se } \\
\text { constitui como um } \\
\text { profissional norteador de } \\
\text { um processo de mudanças } \\
\text { no atual momento que se } \\
\text { apresenta. }\end{array}$ & $\begin{array}{l}\text { Estudo } \\
\text { bibliográfico } \\
\text { análise } \\
\text { documental. }\end{array}$ \\
\hline
\end{tabular}




\begin{tabular}{|c|c|c|c|c|c|c|c|c|c|}
\hline TÍTULO & AUTORES & LOCAL & TIPO & ANO & $\begin{array}{l}\text { PALAVRAS } \\
\text { CHAVE }\end{array}$ & RESUMO & OBJETIVO & JUSTIFICATIVA & METODOLOGIA \\
\hline $\begin{array}{lr}\text { Formação } & \text { de } \\
\text { professores à luz } \\
\text { da História e } \\
\text { cultura afro- } \\
\text { brasileira } \\
\text { africana. }\end{array}$ & 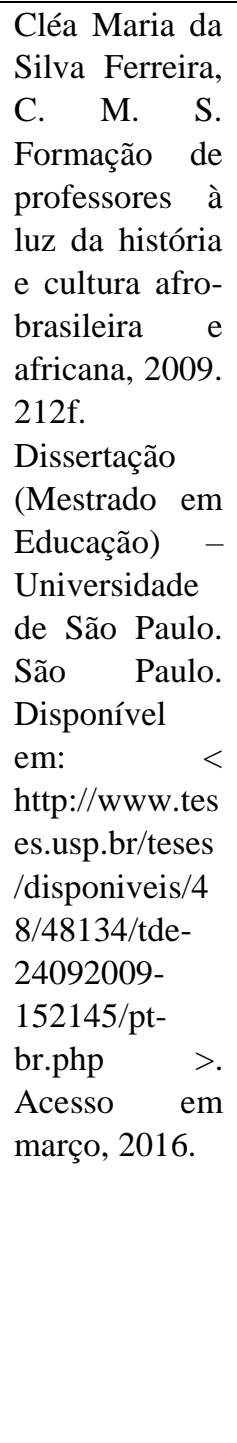 & USP & Dissertação & 2009 & $\begin{array}{lr}\text { Formação } & \text { de } \\
\text { professores. } \\
\text { História } & \text { e } \\
\text { cultura } & \text { afro } \\
\text { brasileira } & \text { e } \\
\text { africana. } & \\
\text { Prática } & \\
\text { reflexiva. } & \\
\text { Transposição } \\
\text { didática. }\end{array}$ & 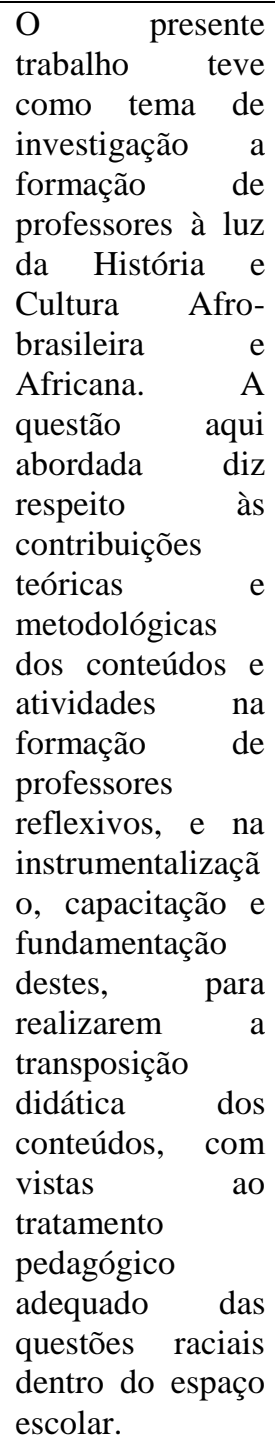 & $\begin{array}{l}\text { Esta pesquisa situa-se na } \\
\text { problemática da formação } \\
\text { continuada de professores à } \\
\text { luz da temática História e } \\
\text { Cultura Afro-Brasileira e } \\
\text { Africana, numa perspectiva } \\
\text { de reflexão sobre seu papel } \\
\text { na formação de professores } \\
\text { reflexivos, e na } \\
\text { instrumentalização destes } \\
\text { para a construção do } \\
\text { conhecimento prático capaz } \\
\text { de tratar de forma } \\
\text { pedagogicamente adequada } \\
\text { às questões raciais no espaço } \\
\text { escolar. }\end{array}$ & $\begin{array}{l}\text { A implementação da Lei } \\
10.639 / 03 \text {, que institui o } \\
\text { ensino de História e } \\
\text { Cultura Afro-Brasileira e } \\
\text { Africana nas escolas, } \\
\text { além de representar uma } \\
\text { ação afirmativa da mais } \\
\text { alta relevância, também } \\
\text { trouxe à tona uma } \\
\text { questão que há muito } \\
\text { vem sendo discutida no } \\
\text { que se refere à qualidade } \\
\text { do ensino nas escolas } \\
\text { brasileiras: a formação de } \\
\text { professores. A situação } \\
\text { ganha contornos mais } \\
\text { delicados por se tratar de } \\
\text { questões raciais. O mito } \\
\text { da democracia racial que } \\
\text { impera no Brasil há } \\
\text { muitos anos precisa ser } \\
\text { desfeito e caberá a estes } \\
\text { profissionais essa difícil } \\
\text { tarefa. }\end{array}$ & $\begin{array}{l}\text { Abordagem } \\
\text { qualitativa; estudo } \\
\text { de caso; } \\
\text { metodologia auto } \\
\text { biográfica aliada ao } \\
\text { levantamento } \\
\text { bibliográfico aliado } \\
\text { ao conteúdo } \\
\text { bibliográfico } \\
\text { produção } \\
\text { educadores. }\end{array}$ \\
\hline
\end{tabular}




\begin{tabular}{|c|c|c|c|c|c|c|c|c|c|}
\hline TÍTULO & AUTORES & LOCAL & TIPO & ANO & $\begin{array}{c}\text { PALAVRAS } \\
\text { CHAVE }\end{array}$ & RESUMO & OBJETIVO & JUSTIFICATIVA & METODOLOGIA \\
\hline $\begin{array}{l}\text { Aprendizagens } \\
\text { de um grupo de } \\
\text { futuros(as) } \\
\text { professores(as) } \\
\text { de química na } \\
\text { elaboração de } \\
\text { conteúdos } \\
\text { pedagógicos } \\
\text { digitais: em face } \\
\text { dos caminhos } \\
\text { abertos pela Lei } \\
\text { Federal no } 10.639 \\
\text { de } 2003 \text {. }\end{array}$ & 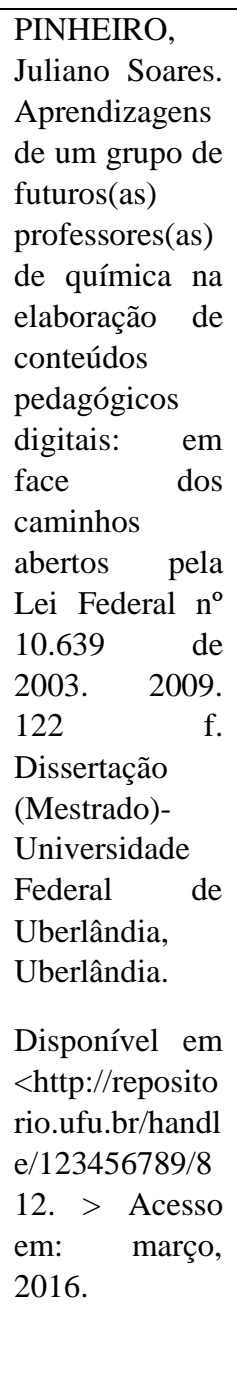 & UFU & Dissertação & 2009 & $\begin{array}{l}\text { Química. África. } \\
\text { Aprendizagens } \\
\text { para docência. } \\
\text { Professores de } \\
\text { química. } \\
\text { Formação } \\
\text { Química. Estudo } \\
\text { e ensino } \\
\text { África } \\
\text { História. } \\
\text { Discriminação } \\
\text { na educação. } \\
\text { Tecnologia } \\
\text { educacional. }\end{array}$ & 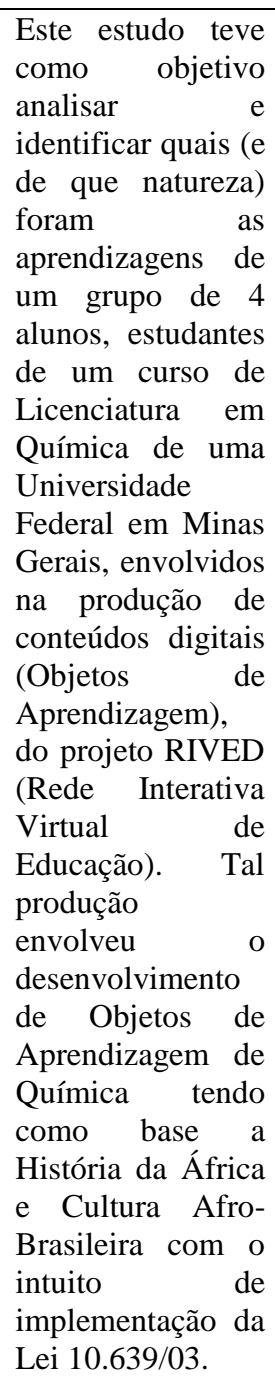 & $\begin{array}{l}\text { Este estudo teve como } \\
\text { objetivo analisar e identificar } \\
\text { quais (e de que natureza) } \\
\text { foram as aprendizagens de um } \\
\text { grupo de } 4 \text { alunos, estudantes } \\
\text { de um curso de Licenciatura } \\
\text { em Química de uma } \\
\text { Universidade Federal em } \\
\text { Minas Gerais, envolvidos na } \\
\text { produção de conteúdos } \\
\text { digitais (Objetos de } \\
\text { Aprendizagem), do projeto } \\
\text { RIVED (Rede Interativa } \\
\text { Virtual de Educação). }\end{array}$ & $\begin{array}{l}\text { Trabalhar na perspectiva } \\
\text { da diversidade étnico- } \\
\text { racial de forma positiva } \\
\text { implicou em revogar o } \\
\text { espontaneísmo pseudo } \\
\text { didático gerado pela falta } \\
\text { de planejamento e a } \\
\text { manutenção ideológica de } \\
\text { que a contribuição do } \\
\text { negro para a sociedade } \\
\text { brasileira foi somente } \\
\text { como mão de obra escrava. }\end{array}$ & $\begin{array}{l}\text { Como técnicas para } \\
\text { construção de dados } \\
\text { foram utilizadas a } \\
\text { aplicação } \\
\text { questionários, } \\
\text { observação } \\
\text { gravação em áudio } \\
\text { digital das reuniões } \\
\text { realizadas com o } \\
\text { grupo de alunos } \\
\text { para discussão das } \\
\text { etapas de produção } \\
\text { dos Objetos de } \\
\text { Aprendizagem, bem } \\
\text { como a análise dos } \\
\text { documentos } \\
\text { produzidos por eles } \\
\text { (design pedagógico } \\
\text { e roteiro) O trabalho } \\
\text { se insere na } \\
\text { perspectiva de uma } \\
\text { pesquisa qualitativa, } \\
\text { caracterizada como } \\
\text { um estudo de caso. }\end{array}$ \\
\hline
\end{tabular}




\begin{tabular}{|c|c|c|c|c|c|c|c|c|c|}
\hline TÍTULO & AUTORES & LOCAL & TIPO & ANO & $\begin{array}{c}\text { PALAVRAS } \\
\text { CHAVE }\end{array}$ & RESUMO & OBJETIVO & JUSTIFICATIVA & METODOLOGIA \\
\hline $\begin{array}{ll}\text { A África } & \text { no } \\
\text { curso } & \text { de } \\
\text { licenciatura } & \text { em } \\
\text { história da } & \text { da } \\
\text { Universidade } \\
\text { Federal do Rio } \\
\text { Grande do Sul: } \\
\text { possibilidades } \\
\text { de efetivação da } \\
\text { lei } 11.645 / 2008 \\
\text { e da lei } \\
\text { 10.639/2003: } \\
\text { um estudo de } \\
\text { caso. }\end{array}$ & 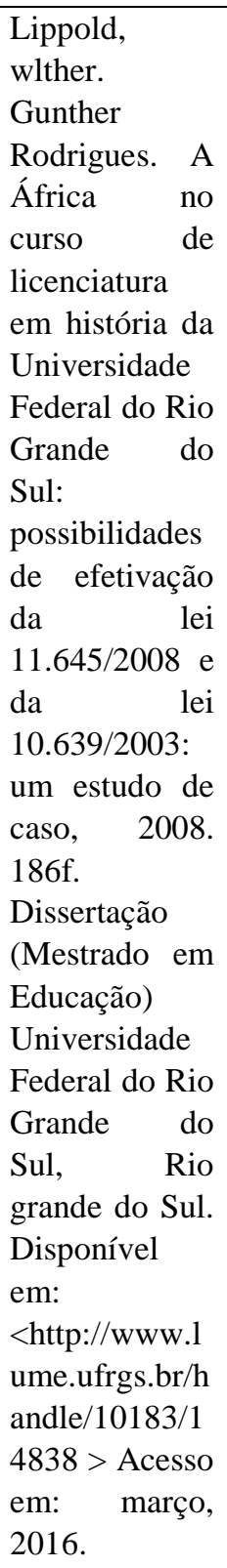 & UFRG & Dissertação & 2008 & $\begin{array}{l}\text { Professor. } \\
\text { Formação. } \\
\text { História. } \\
\text { Cultura afro- } \\
\text { brasileira. } \\
\text { Lei n. } 10.639 \text {, } \\
\text { de } 9 \quad \text { de } \\
\text { janeiro de } \\
2003 .\end{array}$ & 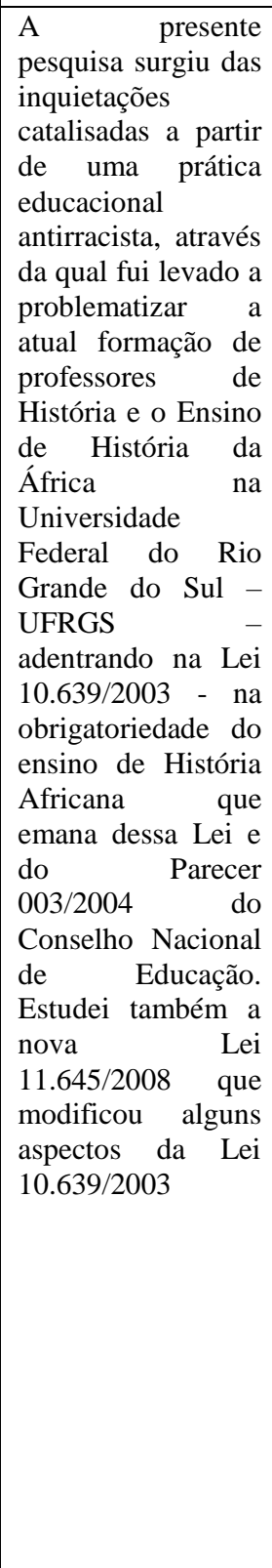 & $\begin{array}{l}\text { Almejo conhecer e } \\
\text { apreender as possibilidades } \\
\text { produzidas pela prática } \\
\text { social e educativa dos } \\
\text { estudantes e professores do } \\
\text { Curso de História da } \\
\text { UFRGS, através das quais se } \\
\text { produziram suas } \\
\text { representações sociais. }\end{array}$ & 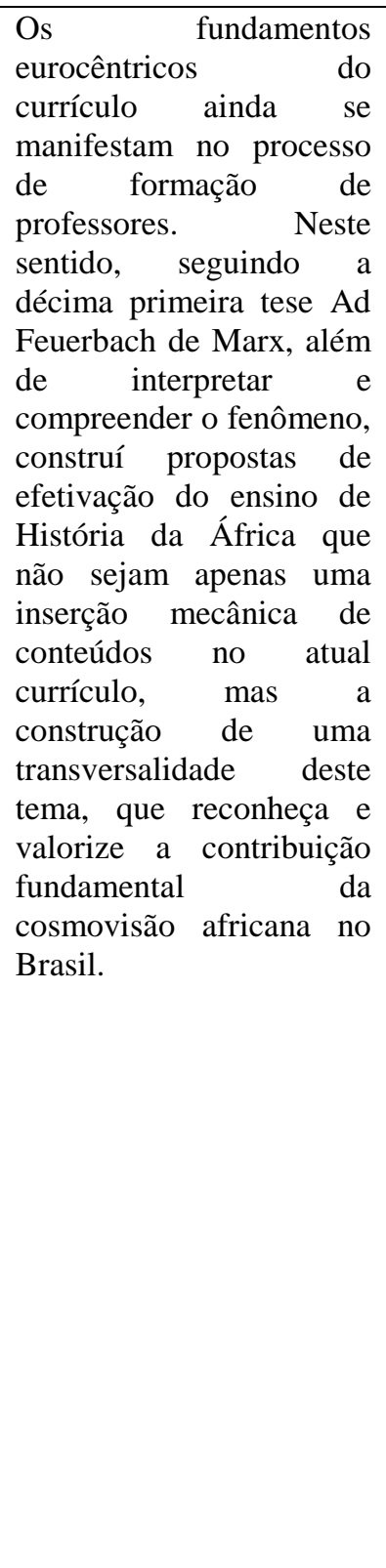 & $\begin{array}{l}\text { Através do Estudo } \\
\text { de Caso, enquanto } \\
\text { metodologia de } \\
\text { pesquisa, valendo- } \\
\text { se de entrevistas } \\
\text { semiestruturadas, } \\
\text { da observação } \\
\text { semi-dirigida em } \\
\text { sala de aula e em } \\
\text { eventos ligados ao } \\
\text { Ensino e História } \\
\text { Africana, da } \\
\text { análise da } \\
\text { documentação } \\
\text { legal afim e do } \\
\text { apoio teórico- } \\
\text { metodológico, } \\
\text { fundamentado no } \\
\text { pensamento de } \\
\text { Marx, Lukács e } \\
\text { Frantz Fanon, }\end{array}$ \\
\hline
\end{tabular}




\begin{tabular}{|c|c|c|c|c|c|c|c|c|c|}
\hline TíTULO & AUTORES & LOCAL & TIPO & ANO & $\begin{array}{c}\text { PALAVRAS } \\
\text { CHAVE }\end{array}$ & RESUMO & OBJETIVO & JUSTIFICATIVA & METODOLOGIA \\
\hline $\begin{array}{l}\text { Velhos } \\
\text { problemas, } \\
\text { novas questões: } \\
\text { Uma análise dos } \\
\text { discursos raciais } \\
\text { na política } \\
\text { nacional do } \\
\text { livro didático. }\end{array}$ & 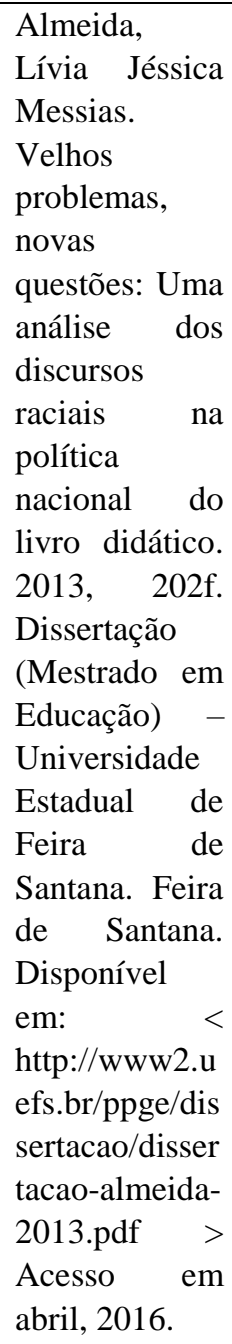 & UEFS & Dissertação & 2013 & $\begin{array}{l}\text { Política do } \\
\text { Livro Didático. } \\
\text { Relações } \\
\text { Etnicorraciais. } \\
\text { Professor. } \\
\text { Habitus. } \\
\text { Políticas } \\
\text { Públicas.. }\end{array}$ & $\begin{array}{l}\text { A presente } \\
\text { pesquisa } \\
\text { objetivou analisar } \\
\text { como a política } \\
\text { nacional do livro } \\
\text { didático legitima } \\
\text { e reproduz } \\
\text { representações } \\
\text { do/a negro/a no } \\
\text { livro didático }\end{array}$ & $\begin{array}{l}\text { O estudo tem por objetivo } \\
\text { apresentar uma analise a } \\
\text { produção de livros didáticos } \\
\text { percebendo a } \\
\text { representatividade do negro } \\
\text { nesses materiais. }\end{array}$ & $\begin{array}{l}\text { numa análise da política } \\
\text { nacional do livro didático } \\
\text { em seus dois eixos, posso } \\
\text { concluir que a referida } \\
\text { política legitima e e } \\
\text { reproduz representações } \\
\text { negativas de } \\
\text { desvalorização do/a } \\
\text { negro/a, por meio de uma } \\
\text { política de } \\
\text { silenciamento/invisibilida } \\
\text { de a partir da não adoção } \\
\text { de medidas/ações } \\
\text { afirmativas para uma } \\
\text { representação positiva do } \\
\text { povo negro no livro } \\
\text { didático. }\end{array}$ & $\begin{array}{l}\text { Pesquisa } \\
\text { documental, com } \\
\text { análise } \\
\text { documentos } \\
\text { oficiais, pesquisa } \\
\text { qualitativa } \\
\text { pesquisa d campo. }\end{array}$ \\
\hline
\end{tabular}




\begin{tabular}{|c|c|c|c|c|c|c|c|c|c|}
\hline TÍTULO & AUTORES & LOCAL & TIPO & ANO & $\begin{array}{c}\text { PALAVRAS } \\
\text { CHAVE }\end{array}$ & RESUMO & OBJETIVO & JUSTIFICATIVA & METODOLOGIA \\
\hline 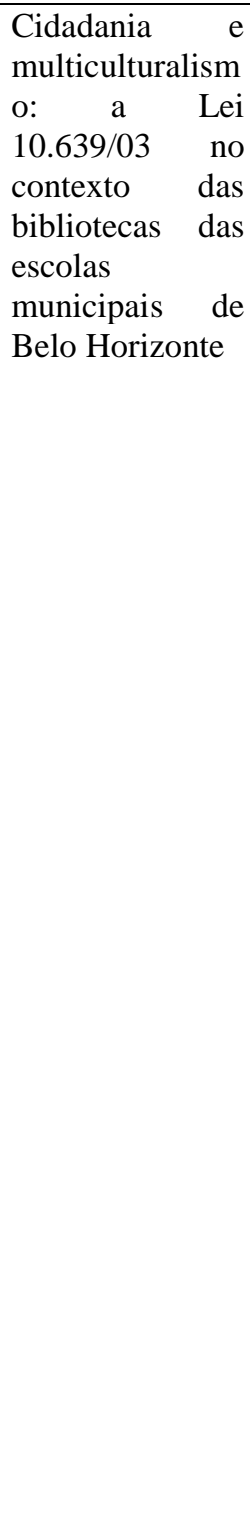 & 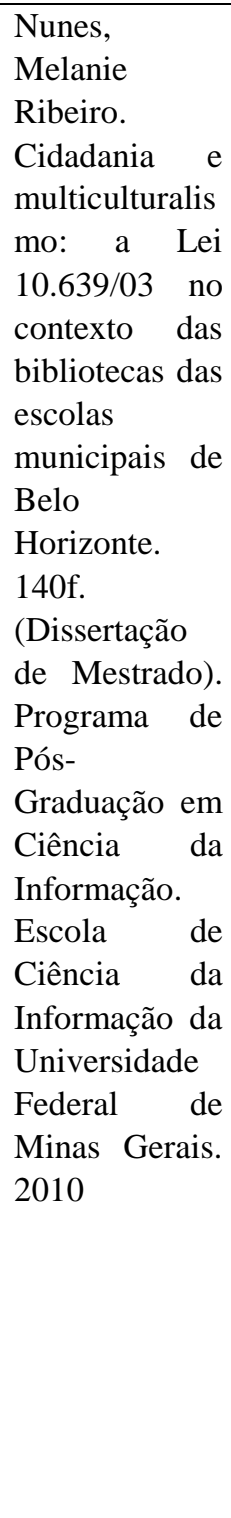 & UFMG & Dissertação & 2010 & $\begin{array}{l}\text { Cidadania; } \\
\text { Multiculturali } \\
\text { smo; Lei } \\
\text { 10.639/03; } \\
\text { Bibliotecas; } \\
\text { Escolas. }\end{array}$ & 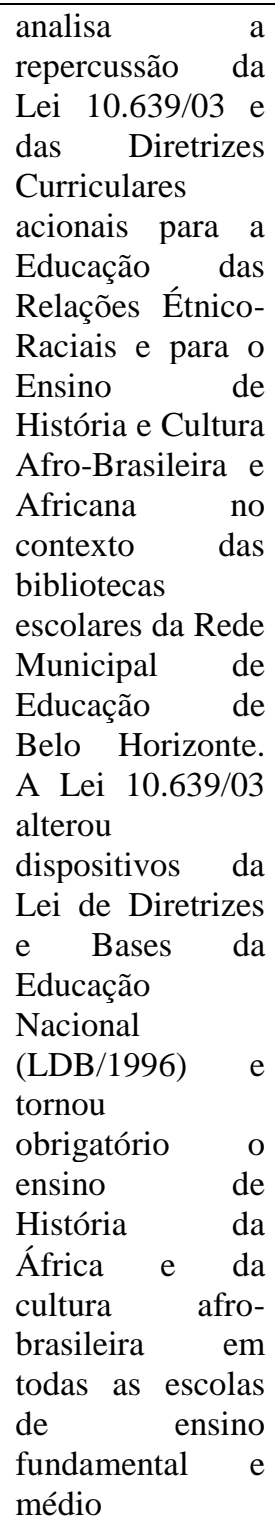 & $\begin{array}{l}\begin{array}{l}\text { Buscou-se neste } \\
\text { recuperar }\end{array} \\
\begin{array}{r}\text { trabalho } \\
\text { algumas }\end{array} \\
\text { concepções e } \\
\text { presentes no debate acerca } \\
\text { da Lei e de suas Diretrizes } \\
\text { Curriculares correlatas. } \\
\text { Procurou-se, ainda, } \\
\text { contextualizar o cenário da } \\
\text { aprovação dessa Lei, } \\
\text { apontando os desafios que } \\
\text { esta indica ao Estado e à } \\
\text { sociedade civil ao dar } \\
\text { visibilidade a temas como a } \\
\text { educação anti-racista, a } \\
\text { pluralidade cultural e o } \\
\text { multiculturalismo, além de } \\
\text { colocar em pauta a discussão } \\
\text { do novo papel do Estado na } \\
\text { conformação da cidadania. }\end{array}$ & 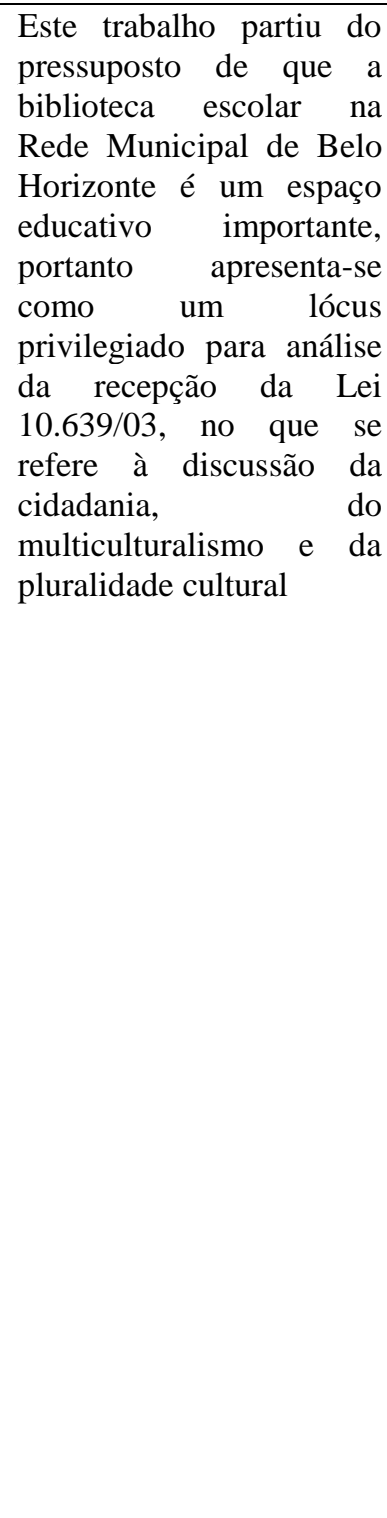 & $\begin{array}{l}\text { Pesquisa } \\
\text { documental, com } \\
\text { análise } \\
\text { documentos } \\
\text { oficiais, pesquisa } \\
\text { qualitativa } \\
\text { pesquisa de campo. }\end{array}$ \\
\hline
\end{tabular}


ANEXO 6 - LEVANTAMENTO BIBLIOGRÁFICO - TESES

\begin{tabular}{|c|c|c|c|c|c|c|c|c|c|}
\hline TÍTULO & AUTORES & LOCAL & TIPO & ANO & $\begin{array}{c}\text { PALAVRAS } \\
\text { CHAVE }\end{array}$ & RESUMO & OBJETIVO & JUSTIFICATIVA & METODOLOGIA \\
\hline $\begin{array}{lr}\text { Das práticas } \\
\text { políticas } \\
\text { jurídicas na } \\
\text { formação de } \\
\text { professores para } \\
\text { educação } \\
\text { étnico-racial. }\end{array}$ & 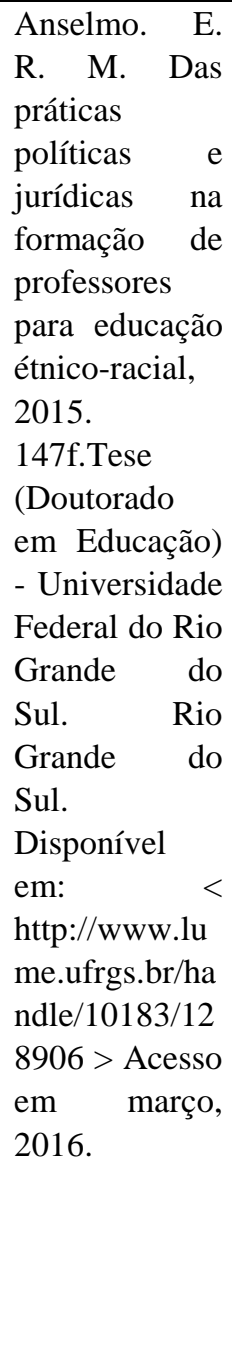 & UFRGS & Tese & 2015 & $\begin{array}{l}\text { Ações } \\
\text { afirmativas. } \\
\text { Estatística. } \\
\text { Formação de } \\
\text { professores. }\end{array}$ & $\begin{array}{l}\text { Esta tese investiga } \\
\text { o modo como os } \\
\text { discursos da } \\
\text { legislação e da } \\
\text { estatística, } \\
\text { produzem efeitos } \\
\text { na formação de } \\
\text { professores - } \\
\text { estabelecendo um } \\
\text { modo de tratar a } \\
\text { temática étnico- } \\
\text { racial na escola. }\end{array}$ & $\begin{array}{l}\begin{array}{l}\text { Pesquisa com } \\
\text { documental das } \\
\text { programas, leis, } \\
\text { diretrizes e projetos, } \\
\text { documentos orientadores do }\end{array} \\
\text { Ministério da } \\
\text { Educação via Secretaria da } \\
\text { Diversidade e Secretaria de } \\
\text { Políticas de Promoção da } \\
\text { Igualdade Racial, bem como } \\
\text { o exame da proposta de } \\
\text { formação de professores } \\
\text { elaborada pelas secretarias } \\
\text { municipais de educação de } \\
\text { Novo } \\
\text { Hamburgo e São Leopoldo, } \\
\text { voltadas à implementação } \\
\text { da Lei 10.639/2003, que } \\
\text { determina a inserção da } \\
\text { temática étnico-racial no } \\
\text { currículo escolar. }\end{array}$ & $\begin{array}{l}\text { Apresenta-se o aporte } \\
\text { teórico das concepções } \\
\text { sobre raças nos campos } \\
\text { da Genética, da } \\
\text { Antropologia, e da } \\
\text { Sociologia, visualizando- } \\
\text { as como dispositivos que } \\
\text { produzem verdades sobre } \\
\text { raças, racismos e } \\
\text { diferenças raciais. } \\
\text { Apresentam-se as } \\
\text { estatísticas, como prática } \\
\text { de intervenção e de } \\
\text { governo da vida. Para } \\
\text { analisar como a questão } \\
\text { racial passou a ser um } \\
\text { discurso de governo, e a } \\
\text { importância de conhecer } \\
\text { minunciosamente a a a para melhor } \\
\text { população para } \\
\text { governá-la. }\end{array}$ & 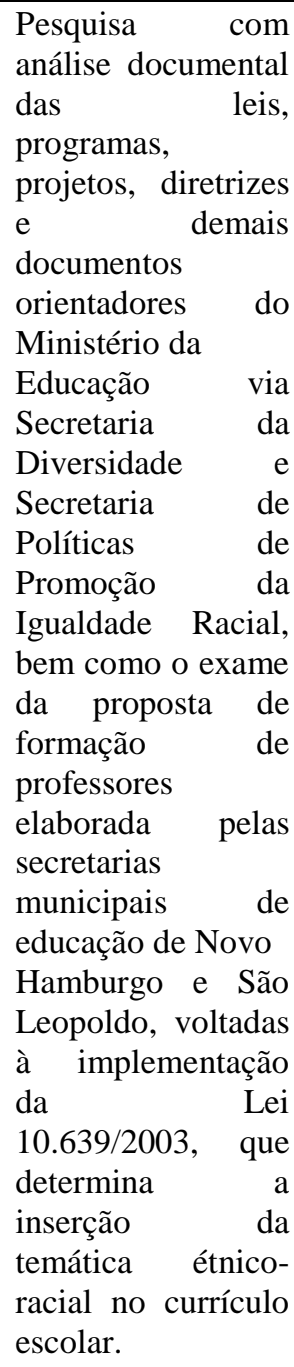 \\
\hline
\end{tabular}




\begin{tabular}{|c|c|c|c|c|c|c|c|c|c|}
\hline TÍTULO & AUTORES & LOCAL & TIPO & ANO & $\begin{array}{l}\text { PALAVRAS } \\
\text { CHAVE }\end{array}$ & RESUMO & OBJETIVO & JUSTIFICATIVA & METODOLOGIA \\
\hline $\begin{array}{l}\text { Representações } \\
\text { sociais sobre } \\
\text { educação } \\
\text { étnico-racial de } \\
\text { professores de } \\
\text { Ituiutaba-MG e } \\
\text { suas } \\
\text { contribuições } \\
\text { para a formação } \\
\text { docente. }\end{array}$ & $\begin{array}{l}\text { Gonçalves. } \\
\text { Luciane } \\
\text { Ribeiro Dias, } \\
\text { Representaçõe } \\
\text { s sociais sobre } \\
\text { educação } \\
\text { étnico-racial } \\
\text { de professores } \\
\text { de Ituiutaba- } \\
\text { MG e suas } \\
\text { contribuições } \\
\text { para a } \\
\text { formação } \\
\text { docente, 2011. } \\
\text { 177f Tese } \\
\text { (Doutorado } \\
\text { em Educação) } \\
\text { - Universidade } \\
\text { Estadual de } \\
\text { Campinas. } \\
\text { Campinas. } \\
\text { Disponível } \\
\text { em: } \\
\text { http://www.bi } \\
\text { bliotecadigital. } \\
\text { unicamp.br/do } \\
\text { cument/?code } \\
=000831544> \\
\text {. Acesso em: } \\
\text { março, 2016. }\end{array}$ & UNICAMP & Tese & 2011 & $\begin{array}{l}\text { Representações } \\
\text { sociais. } \\
\text { Relações } \\
\text { étnicas. } \\
\text { Relações raciais. } \\
\text { Educação. } \\
\text { Formação } \\
\text { docente. } \\
\text { Pedagogia. }\end{array}$ & 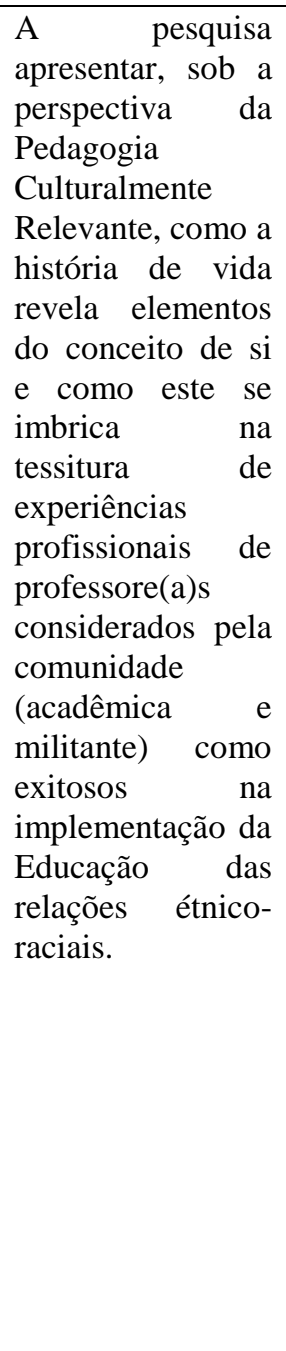 & $\begin{array}{l}\text { Essa pesquisa objetiva } \\
\text { compreender, sob a } \\
\text { perspectiva da Pedagogia } \\
\text { Culturalmente Relevante, } \\
\text { como a história de vida } \\
\text { revela elementos do } \\
\text { conceito de si e como este } \\
\text { se imbrica na tessitura de } \\
\text { experiências profissionais } \\
\text { de professore(a)s } \\
\text { considerados pela } \\
\text { comunidade (acadêmica e } \\
\text { militante) como exitosos na } \\
\text { implementação da Educação } \\
\text { das relações étnico-raciais. }\end{array}$ & $\begin{array}{l}\text { A legislação educacional, } \\
\text { através da Lei } 10.639 / 03 \\
\text { e de outros aparatos, } \\
\text { reconhece a necessidade } \\
\text { de estruturar a Educação } \\
\text { das relações étnico- } \\
\text { raciais. Contudo, ainda } \\
\text { são poucas e pontuais as } \\
\text { experiências no cotidiano } \\
\text { escolar que possibilitam a } \\
\text { concretização da lei }\end{array}$ & $\begin{array}{l}\text { A partir da } \\
\text { observação de } \\
\text { campo, entrevista } \\
\text { livre e roda de } \\
\text { conversa. Para } \\
\text { interpretação, } \\
\text { recorri aos dois } \\
\text { processos definidos } \\
\text { na abordagem } \\
\text { processual da } \\
\text { Teoria das } \\
\text { Representações } \\
\text { Sociais: ancoragem } \\
\text { e objetivação, que } \\
\text { embasaram as } \\
\text { inferências. }\end{array}$ \\
\hline
\end{tabular}




\begin{tabular}{|c|c|c|c|c|c|c|c|c|c|}
\hline TÍTULO & AUTORES & LOCAL & TIPO & ANO & $\begin{array}{c}\text { PALAVRAS } \\
\text { CHAVE }\end{array}$ & RESUMO & OBJETIVO & JUSTIFICATIVA & METODOLOGIA \\
\hline $\begin{array}{l}\text { O estudo da } \\
\text { História } \\
\text { cultura afro- } \\
\text { brasileira no } \\
\text { ensino } \\
\text { fundamental: } \\
\text { currículos, } \\
\text { formação } \\
\text { prática docente. }\end{array}$ & $\begin{array}{l}\text { Silva, G. C. } \\
\text { O estudo da } \\
\text { história e } \\
\text { cultura afro- } \\
\text { brasileira no } \\
\text { ensino } \\
\text { fundamental: } \\
\text { currículos, } \\
\text { formação e } \\
\text { prática } \\
\text { docente, 2011. } \\
212 \text { f. Tese } \\
\text { (Doutorado } \\
\text { em Educação) } \\
\text {-Universidade } \\
\text { Federal de } \\
\text { Uberlândia, } \\
\text { Uberlândia, } \\
\text { 2011. } \\
\text { Disponível } \\
\text { em: } \\
\text { http://repositor } \\
\text { io.ufu.br/handl } \\
\text { e/123456789/8 } \\
\text { 93 > Acesso } \\
\text { em: março, } \\
\text { 2016. }\end{array}$ & UFU & Tese & 2011 & 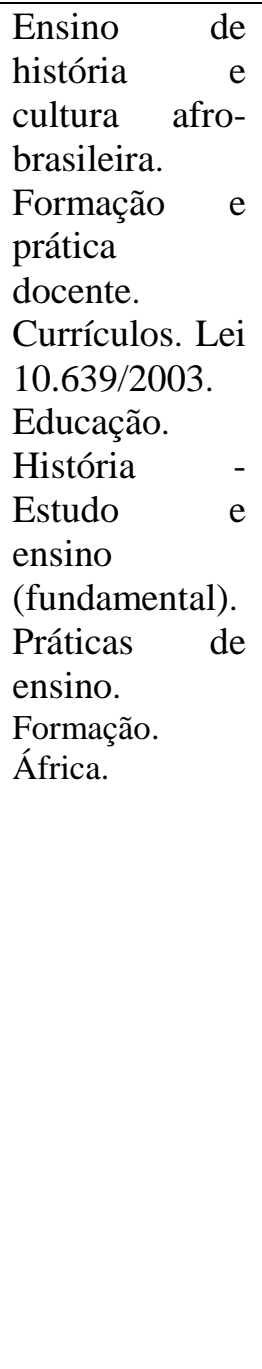 & 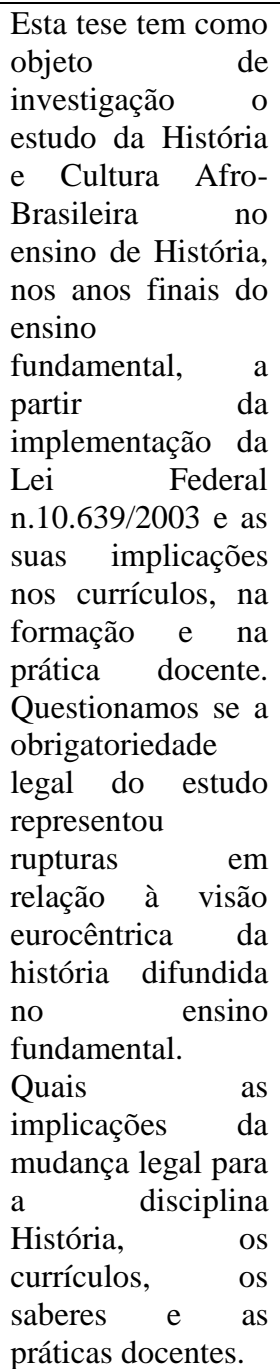 & $\begin{array}{l}\text { Os objetivos da investigação } \\
\text { foram: analisar a legislação } \\
\text { federal sobre o tema e suas } \\
\text { repercussões no ensino de } \\
\text { História nos anos finais do } \\
\text { ensino fundamental; discutir } \\
\text { o lugar e papel da disciplina } \\
\text { História no currículo escolar } \\
\text { e no contexto legal brasileiro; } \\
\text { analisar a produção } \\
\text { acadêmica sobre o tema no } \\
\text { âmbito dos Programas de } \\
\text { Pós-Graduação; analisar a } \\
\text { formação dos professores de } \\
\text { História nos cursos de } \\
\text { licenciatura e em outros } \\
\text { espaços em relação ao estudo } \\
\text { da história e da cultura afro- } \\
\text { brasileira; identificar } \\
\text { mudanças e permanências na } \\
\text { atuação dos professores de } \\
\text { História após a aprovação da } \\
\text { Legislação que obriga o } \\
\text { estudo de História e Cultura } \\
\text { Afro-Brasileira; investigar as } \\
\text { implicações a a da } \\
\text { obrigatoriedade do estudo da } \\
\text { temática na construção dos } \\
\text { saberes e das práticas } \\
\text { docentes; e analisar a } \\
\text { produção de material didático } \\
\text { (livros didáticos, artigos, } \\
\text { revistas e filmes) sobre o } \\
\text { tema, utilizada pelos } \\
\text { professores investigados. }\end{array}$ & $\begin{array}{lr}\text { Importância } & \text { de } \\
\text { reconhecer as } \\
\text { permanências e } \\
\text { mudanças, as diferenças } \\
\text { entre as redes públicas e } \\
\text { privadas, o papel da } \\
\text { formação continuada do } \\
\text { professor no ensino, a } \\
\text { importância da gestão da } \\
\text { escola na aplicação da Lei } \\
\text { e a capacidade crítica e } \\
\text { criativa dos professores } \\
\text { para a atuação em áreas } \\
\text { em que a formação inicial } \\
\text { não foi possível. }\end{array}$ & 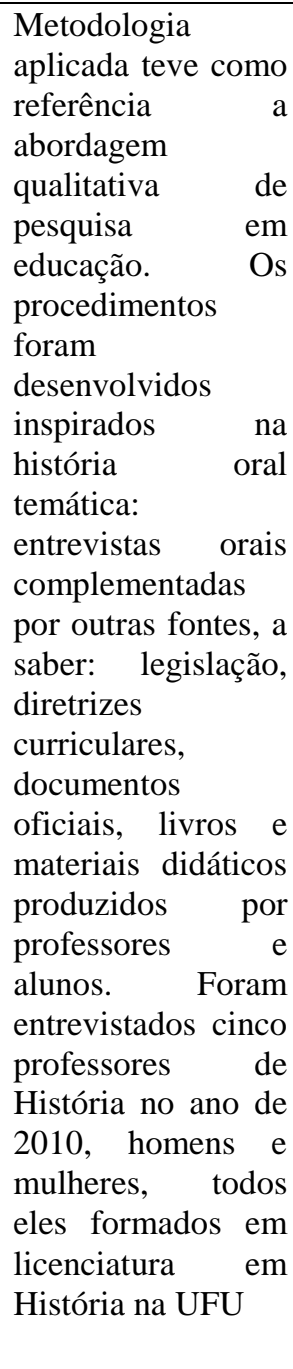 \\
\hline
\end{tabular}




\begin{tabular}{|c|c|c|c|c|c|c|c|c|c|}
\hline TÍTULO & AUTORES & LOCAL & TIPO & ANO & $\begin{array}{c}\text { PALAVRAS } \\
\text { CHAVE }\end{array}$ & RESUMO & OBJETIVO & JUSTIFICATIVA & METODOLOGIA \\
\hline \begin{tabular}{lr}
\multicolumn{2}{l}{ Identidades } \\
cultura a \\
brasileira: & afro- \\
formação & de \\
professoras & na \\
escola e & na \\
universidade &
\end{tabular} & $\begin{array}{l}\text { Lima, M. N. } \\
\text { M. Identidades } \\
\text { e cultura afro- } \\
\text { brasileira: a } \\
\text { formação de } \\
\text { professoras na } \\
\text { escola e na } \\
\text { universidade, } \\
\text { 2007. 221f. } \\
\text { Tese } \\
\text { (Doutorado } \\
\text { em Letras e } \\
\text { Linguística) - } \\
\text { Universidade } \\
\text { Federal da } \\
\text { Bahia, } \\
\text { Salvador. } \\
\text { Salvador. } \\
\text { Disponível } \\
\text { em: } \\
\text { https://reposito } \\
\text { rio.ufba.br/ri/b } \\
\text { itstream/ri/109 } \\
\text { 66/1/Maria\%2 } \\
\text { 0Nazare\%20 } \\
\text { Mota\%20de\% } \\
\text { 20Lima.pdf > } \\
\text { Acesso em } \\
\text { março, 2016. }\end{array}$ & UFBA & Tese & 2007 & $\begin{array}{l}\text { Discurso e } \\
\text { poder. } \\
\text { Formação de } \\
\text { professoras. } \\
\text { Identidade } \\
\text { étnico-racial. }\end{array}$ & 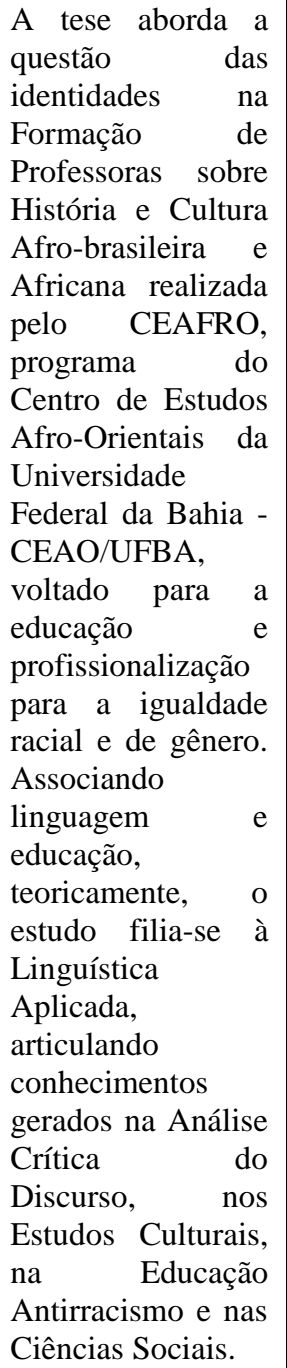 & $\begin{array}{l}\text { A criação de vínculos e de } \\
\text { relações horizontais entre } \\
\text { formadoras e professoras, a } \\
\text { distinção entre formação e } \\
\text { militância, os desafios } \\
\text { enfrentados no processo } \\
\text { formativo são discutidos, } \\
\text { evidenciando, a partir daí, } \\
\text { como ter as professoras } \\
\text { como aliadas na reversão do } \\
\text { racismo pela educação. }\end{array}$ & $\begin{array}{l}\text { Importância da criação de } \\
\text { vínculos e de relações } \\
\text { horizontais entre } \\
\text { formadoras e professoras, } \\
\text { a distinção entre } \\
\text { formação e militância, o } \\
\text { levantamento das } \\
\text { dificuldades na formação } \\
\text { de professores no geral, } \\
\text { sobretudo, em relação à } \\
\text { temática racial. }\end{array}$ & $\begin{array}{l}\text { Estudo } \\
\text { bibliográfico e } \\
\text { análise documental }\end{array}$ \\
\hline
\end{tabular}




\begin{tabular}{|c|c|c|c|c|c|c|c|c|c|}
\hline TÍTULO & AUTORES & LOCAL & TIPO & ANO & $\begin{array}{c}\text { PALAVRAS } \\
\text { CHAVE }\end{array}$ & RESUMO & OBJETIVO & JUSTIFICATIVA & METODOLOGIA \\
\hline $\begin{array}{l}\text { A lei 10.639/03 } \\
\text { e o ensino de } \\
\text { artes nas séries } \\
\text { iniciais: } \\
\text { políticas } \\
\text { afirmativas e } \\
\text { Folclorização } \\
\text { racista. }\end{array}$ & $\begin{array}{l}\text { Santana, Jair. } \\
\text { A lei } \\
10.639 / 03 \text { e o } \\
\text { ensino de artes } \\
\text { nas séries } \\
\text { iniciais: } \\
\text { políticas } \\
\text { afirmativas e } \\
\text { Folclorização } \\
\text { racista. 2010, } \\
\text { 251f. Tese } \\
\text { (Doutorado } \\
\text { em Educação) } \\
- \\
\text { Universidade } \\
\text { Federal do } \\
\text { Paraná, } \\
\text { Curitiba. } \\
\text { Disponível } \\
\text { em: } \\
\text { http://www.pp } \\
\text { ge.ufpr.br/tese } \\
\text { s\%20d2010/d2 } \\
010 \_J a i r \% 20 S \\
\text { antana.pdf > } \\
\text { Acesso em } \\
\text { abril, 2016. }\end{array}$ & UFPR & Tese & 2010 & $\begin{array}{l}\text { Políticas } \\
\text { afirmativas. Lei } \\
\text { n. } \quad 10.639 / 03 . \\
\text { Ensino de Artes. } \\
\text { Folclorização } \\
\text { racista }\end{array}$ & $\begin{array}{l}\text { A tese discute "A } \\
\text { Lei } 10.639 / 03 \text { e o } \\
\text { ensino de artes } \\
\text { nas séries iniciais: } \\
\text { políticas } \\
\text { afirmativas e } \\
\text { Folclorização } \\
\text { racista". Analisa a } \\
\text { implementação da } \\
\text { obrigatoriedade } \\
\text { legal do ensino da } \\
\text { Cultura Afro- } \\
\text { Brasileira e } \\
\text { Africana na } \\
\text { escola, } \\
\text { promulgada em } \\
\text { 2003, no que } \\
\text { tange } \\
\text { especificamente } \\
\text { ao ensino de Arte, } \\
\text { em Escolas } \\
\text { Públicas de um } \\
\text { Município do } \\
\text { Estado do Paraná. }\end{array}$ & $\begin{array}{l}\text { A questão suscitada, } \\
\text { portanto, é a de analisar o } \\
\text { que está e o que não está } \\
\text { sendo ensinado nas escolas, } \\
\text { como decorrência da Lei, e } \\
\text { de que formas isso se dá, na } \\
\text { perspectiva dos professores } \\
\text { responsáveis por esta } \\
\text { implementação. }\end{array}$ & $\begin{array}{l}\text { A justificativa para a } \\
\text { realização do trabalho } \\
\text { está pautada na } \\
\text { concepção de que exista } \\
\text { uma ignorância de } \\
\text { consciência e de atitude } \\
\text { em relação ao negro e sua } \\
\text { cultura, bem como à } \\
\text { naturalização pejorativa } \\
\text { com ou sem intenção de } \\
\text { fazê-lo das características } \\
\text { culturais e de aparência } \\
\text { nos espaços escolares. } \\
\text { Toda esta preocupação } \\
\text { geradora da pesquisa, no } \\
\text { caso do autor do trabalho, } \\
\text { é umbilicalmente } \\
\text { atravessada pela história } \\
\text { de vida de alguém que } \\
\text { um dia na condição de } \\
\text { negro, órfão e pobre, } \\
\text { constitui por si mesmo } \\
\text { representação icônica da } \\
\text { população de crianças } \\
\text { negras vítimas do do } \\
\text { preconceito e da da } \\
\text { discriminação, cuja Lei } \\
\text { n.o } 10.639 / 03 \text { pretende } \\
\text { defender. }\end{array}$ & $\begin{array}{l}\text { Pesquisa } \\
\text { documental, com } \\
\text { análise } \\
\text { documentos } \\
\text { oficiais, pesquisa } \\
\text { qualitativa } \text { e } \\
\text { quantitativa } \\
\text { pesquisa de campo }\end{array}$ \\
\hline
\end{tabular}




\begin{tabular}{|c|c|c|c|c|c|c|c|c|c|}
\hline TÍTULO & AUTORES & LOCAL & TIPO & ANO & $\begin{array}{l}\text { PALAVRAS } \\
\text { CHAVE }\end{array}$ & RESUMO & OBJETIVO & JUSTIFICATIVA & METODOLOGIA \\
\hline $\begin{array}{l}\text { Na escola com } \\
\text { os Orixás: O } \\
\text { ensino das } \\
\text { religiões afro- } \\
\text { brasileiras na } \\
\begin{array}{l}\text { aplicação da Lei } \\
10.639 .\end{array}\end{array}$ & 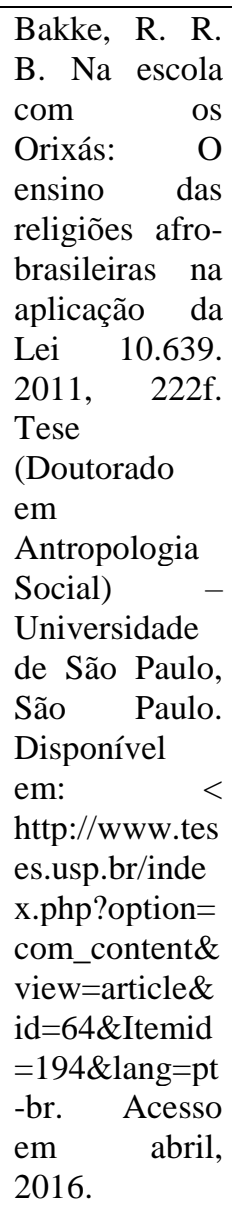 & USP & Tese & 2011 & $\begin{array}{l}\text { cultura } \quad \mathrm{e} \\
\text { religiões afro- } \\
\text { brasileiras } \\
\text { educação } \\
\text { identidade } \\
\text { cultural } \\
\text { símbolos étnicos }\end{array}$ & 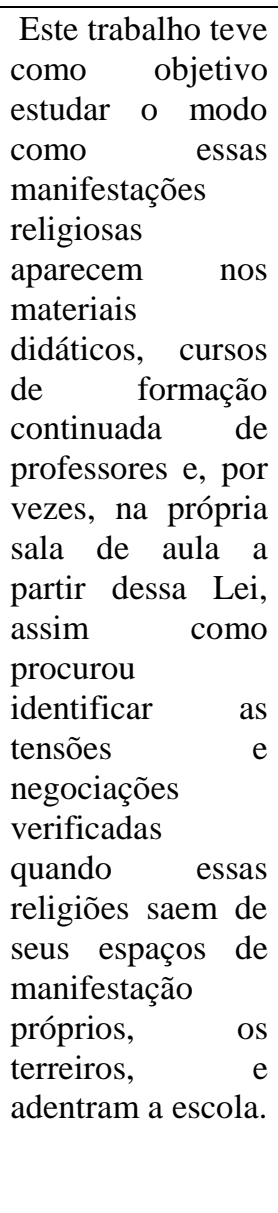 & $\begin{array}{l}\text { As relações entre a visão de } \\
\text { mundo religiosa e do senso } \\
\text { comum (presente nos } \\
\text { discursos e práticas de } \\
\text { professores e alunos } \\
\text { praticantes de diferentes } \\
\text { denominações religiosas: } \\
\text { como o catolicismo, } \\
\text { pentecostalismo etc.) com o } \\
\text { ensino e aprendizado de } \\
\text { valores } \\
\text { simultaneamente vistos } \\
\text { religiosos e como } \\
\text { culturais étnicos a serem } \\
\text { mobilizados na constituição } \\
\text { de identidades diferenciais) } \\
\text { constituem, portanto, o foco } \\
\text { desta pesquisa }\end{array}$ & 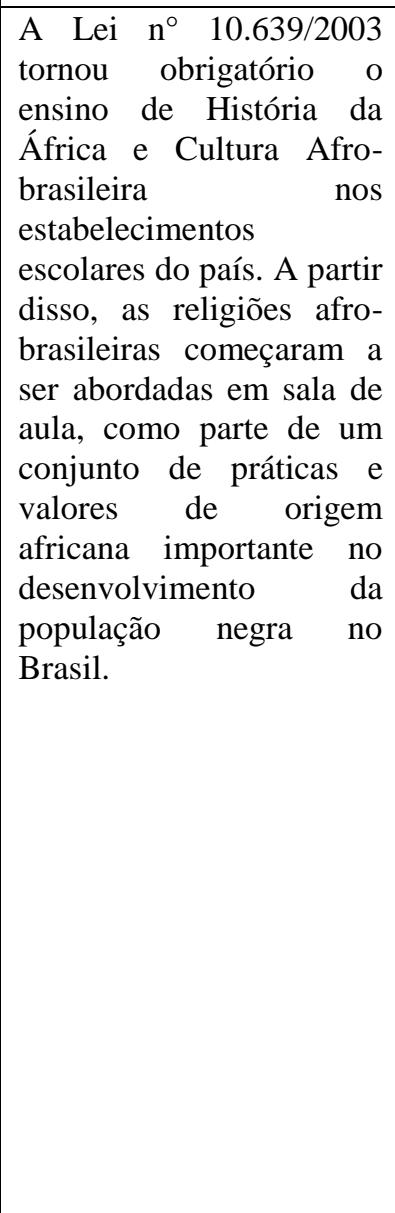 & $\begin{array}{l}\text { Pesquisa } \\
\text { documental, com } \\
\text { análise } \\
\text { documentos } \\
\text { oficiais, pesquisa } \\
\text { qualitativa } \\
\text { quantitativa } \\
\text { pesquisa de campo. }\end{array}$ \\
\hline
\end{tabular}




\begin{tabular}{|c|c|c|c|c|c|c|c|c|c|}
\hline TÍTULO & AUTORES & LOCAL & TIPO & ANO & $\begin{array}{l}\text { PALAVRAS } \\
\text { CHAVE }\end{array}$ & RESUMO & OBJETIVO & JUSTIFICATIVA & METODOLOGIA \\
\hline $\begin{array}{ll}\text { O negro } & \text { e a } \\
\text { cultura } & \text { afro- } \\
\text { brasileira: uma } & \text { umalicolagem } \\
\text { bricultural do } \\
\text { multicul } \\
\text { ensino de } \\
\text { Geografia }\end{array}$ & $\begin{array}{l}\text { Mota, } \\
\text { Edimilson } \\
\text { Antônio. O } \\
\text { negro e a } \\
\text { cultura afro- } \\
\text { brasileira: uma } \\
\text { bricolagem } \\
\text { multicultural } \\
\text { do ensino de } \\
\text { geografia. } \\
\text { 2013, 222f. } \\
\text { Tese } \\
\text { (Doutorado } \\
\text { em Educação) } \\
-\quad \text { Faculdade } \\
\text { de Educação, } \\
\text { Universidade } \\
\text { Federal do Rio } \\
\text { de Janeiro, } \\
\text { Rio de } \\
\text { Janeiro. } \\
\text { Disponível } \\
\text { em: } \\
\text { http://www.ed } \\
\text { ucacao.ufrj.br/ } \\
\text { tedmilsonmota } \\
\text {.pdf > } \\
\text { Acesso em } \\
\text { abril, 2016. }\end{array}$ & UFRJ & Tese & 2013 & $\begin{array}{l}\text { Negro; cultura } \\
\text { afro-brasileira; } \\
\text { livro didático; } \\
\text { multiculturalism } \\
\text { o } \\
\text { emancipatório; } \\
\text { reconhecimento; } \\
\text { ensino de } \\
\text { geografia. }\end{array}$ & $\begin{array}{l}\text { A homologação } \\
\text { da lei } 10.639 \text { em } \\
\text { janeiro de 2003, } \\
\text { tornou-se } \\
\text { obrigatório o } \\
\text { ensino da história } \\
\text { da África e da } \\
\text { cultura afro- } \\
\text { brasileira em toda } \\
\text { a educação básica. } \\
\text { Com isso, o } \\
\text { campo do } \\
\text { currículo foi } \\
\text { levado a repensar } \\
\text { o seu sentido, em } \\
\text { termos de como } \\
\text { têm sido } \\
\text { abordadas as } \\
\text { disciplinas, e em } \\
\text { que perspectiva } \\
\text { pedagogicamente } \\
\text { estas temáticas } \\
\text { têm sido } \\
\text { apresentadas nos } \\
\text { livros didáticos. } \\
\text { No caso do ensino } \\
\text { da Geografia. }\end{array}$ & $\begin{array}{l}\text { O presente estudo teve } \\
\text { como objetivo resgatar a } \\
\text { importância do negro e da } \\
\text { cultura afro-brasileira, a } \\
\text { partir de recortes } \\
\text { discursivos extraídos dos } \\
\text { livros didáticos dessa } \\
\text { disciplina no sétimo ano, } \\
\text { com base nas categorias de } \\
\text { lugar, espaço, paisagem, } \\
\text { região e população. O } \\
\text { objetivo foi saber a partir de } \\
\text { quais paradigmas são } \\
\text { construídas estas } \\
\text { abordagens, e em que } \\
\text { medida elas coadunam com } \\
\text { o multiculturalismo } \\
\text { emancipatório. }\end{array}$ & $\begin{array}{l}\text { Com a homologação da } \\
\text { lei } 10.639 \text { em janeiro de } \\
2003 \text {, tornou-se } \\
\text { obrigatório o ensino da } \\
\text { história da África e da } \\
\text { cultura afro-brasileira em } \\
\text { toda a educação básica. } \\
\text { Com isso, o campo do } \\
\text { currículo foi levado a } \\
\text { repensar o seu sentido, } \\
\text { em termos de como têm } \\
\text { sido abordadas as } \\
\text { disciplinas, e em que } \\
\text { perspectiva } \\
\text { pedagogicamente estas } \\
\text { temáticas têm sido } \\
\text { apresentadas nos livros } \\
\text { didáticos. }\end{array}$ & $\begin{array}{l}\text { Estudo } \\
\text { bibliográfico e } \\
\text { análise documental }\end{array}$ \\
\hline
\end{tabular}

\begin{tabular}{l|l|l|l|l|l|l|l|l|l}
\hline TÍTULO & AUTORES & LOCAL & TIPO & ANO & $\begin{array}{l}\text { PALAVRAS } \\
\text { CHAVE }\end{array}$ & RESUMO & OBJETIVO & JUSTIFICATIVA & METODOLOGIA \\
\hline
\end{tabular}




\begin{tabular}{|c|c|c|c|c|c|c|c|c|c|}
\hline $\begin{array}{l}\text { Currículo e } \\
\text { reprodução da } \\
\text { desigualdade: } \\
\text { análise da } \\
\text { proposta } \\
\text { curricular do } \\
\text { estado de São } \\
\text { Paulo para a } \\
\text { disciplina de } \\
\text { História }\end{array}$ & $\begin{array}{l}\text { Luciano, } \\
\text { Tiago Ricardo. } \\
\text { Currículo e } \\
\text { reprodução da } \\
\text { desigualdade: } \\
\text { análise da } \\
\text { Proposta } \\
\text { Curricular do } \\
\text { estado de São } \\
\text { Paulo para a } \\
\text { disciplina de } \\
\text { História. 2016. } \\
\text { 122f. } \\
\text { Dissertação } \\
\text { (Mestrado em } \\
\text { Educação). } \\
\text { Bauru, } \\
\text { Universidade } \\
\text { Estadual } \\
\text { Paulista “Julio } \\
\text { de Mesquita } \\
\text { Filho”, 2016. }\end{array}$ & UNESP & Dissertação & 2016 & $\begin{array}{l}\text { Currículo; } \\
\text { Lei;10.639/2003 } \\
\text { Material } \\
\text { didático. }\end{array}$ & $\begin{array}{lr}\text { A pesquisa } & \text { se } \\
\text { propõe } & \text { a } \\
\text { investigar como é } \\
\text { apresentada } & \text { e } \\
\text { desenvolvida } & \text { a } \\
\text { história da } & \text { África } \\
\text { e cultura } & \text { afro- } \\
\text { brasileira } & \text { na } \\
\text { Proposta } & \\
\text { Curricular } & \text { do } \\
\text { Ensino Médio das } \\
\text { escolas } & \text { da } \\
\text { SEE/SP. } & \text { Além } \\
\text { disso, } & \end{array}$ & $\begin{array}{l}\text { pretende-se elucidar aos } \\
\text { educadores que tanto o } \\
\text { currículo, como os livros } \\
\text { didáticos não são recursos } \\
\text { pedagógicos neutros e } \\
\text { podem carregar em si uma } \\
\text { ideologia e contribuir para a } \\
\text { reprodução de valores dos } \\
\text { grupos dominantes. }\end{array}$ & $\begin{array}{l}\text { Considerando que o } \\
\text { Caderno do Aluno, } \\
\text { destinado ao Ensino } \\
\text { Médio nas escolas do } \\
\text { estado de São Paulo, é o } \\
\text { principal instrumento de } \\
\text { ensino e aprendizagem } \\
\text { utilizados pelos docentes, } \\
\text { até pela dificuldade para } \\
\text { aquisição de diferentes } \\
\text { materiais, propomos a } \\
\text { análise destes Cadernos, } \\
\text { coadunada à Proposta } \\
\text { Curricular para a } \\
\text { disciplina de História, a } \\
\text { Lei 10.639/2003 e as } \\
\text { possibilidades de } \\
\text { intervenção. Nessa } \\
\text { perspectiva, propomos } \\
\text { um conjunto de } \\
\text { atividades - sequência } \\
\text { didática - na qual são } \\
\text { considerados os valores } \\
\text { culturais africanos para a } \\
\text { formação do Brasil, como } \\
\text { forma de reconhecer a } \\
\text { diversidade cultural e, } \\
\text { ainda refletir sobre as } \\
\text { manifestações a na no } \\
\text { preconceituosas tanto no } \\
\text { ambiente escolar como } \\
\text { também na sociedade } \\
\text { como um todo }\end{array}$ & $\begin{array}{l}\text { Pesquisa } \\
\text { documental, com } \\
\text { análise } \\
\text { documentos } \\
\text { oficiais, pesquisa } \\
\text { qualitativa }\end{array}$ \\
\hline
\end{tabular}




\begin{tabular}{|c|c|c|c|c|c|c|c|c|c|}
\hline TÍTULO & AUTORES & LOCAL & TIPO & ANO & $\begin{array}{l}\text { PALAVRAS } \\
\text { CHAVE }\end{array}$ & RESUMO & OBJETIVO & JUSTIFICATIVA & METODOLOGIA \\
\hline $\begin{array}{l}\text { O ensino de } \\
\text { História, cultura } \\
\text { africana e afro- } \\
\text { brasileira, na } \\
\text { perspectiva da } \\
\text { lei no } \\
10.639 / 2003 \text { : } \\
\text { análise de } \\
\text { políticas } \\
\text { públicas na E.E. } \\
\text { Prof. Hélio } \\
\text { palermo, cidade } \\
\text { de Franca - SP }\end{array}$ & $\begin{array}{l}\text { Borges, } \\
\text { Marley de } \\
\text { Fátima } \\
\text { Morais } \\
\text { Ensino de } \\
\text { História, } \\
\text { Cultura } \\
\text { Africana e } \\
\text { Afro- } \\
\text { Brasileira, na } \\
\text { perspectiva da } \\
\text { Lei No } \\
\text { 10.639/2003: } \\
\text { análise de } \\
\text { políticas } \\
\text { públicas na } \\
\text { EE. Prof. } \\
\text { Hélio } \\
\text { Palermo. } \\
\text { SIPPEDES } \\
\text { Franca, 2016. } \\
\text { Disponível } \\
\text { em: < } \\
\text { http://www.fra } \\
\text { nca.unesp.br/ } \\
\text { Home/Pos- } \\
\text { graduacao/- } \\
\text { planejamentoe } \\
\text { analisedepoliti } \\
\text { caspublicas/iis } \\
\text { ippedes2016/ } \\
\text { marley.pdf> } \\
\text { Acesso em: } 22 \\
\text { de janeiro de } \\
\text { 2018. }\end{array}$ & UNESP & Dissertação & 2016 & $\begin{array}{l}\text { Educação } \\
\text { Questões- } \\
\text { Étnico-racial } \\
\text { Lei } \quad \mathrm{N}^{\circ} \\
10.639 / 2003\end{array}$ & $\begin{array}{l}\text { A pesquisa } \\
\text { analisa como está } \\
\text { sendo inserido o } \\
\text { estudo de } \\
\text { "História, Cultura } \\
\text { Africana e Afro- } \\
\text { Brasileira" e o seu } \\
\text { nível de } \\
\text { enraizamento à } \\
\text { luz da Lei no } \\
\text { 10.639/2003 } \\
\text { tendo como } \\
\text { referência uma } \\
\text { escola pública do } \\
\text { interior da cidade } \\
\text { d e São Paulo. }\end{array}$ & $\begin{array}{l}\text { Procura apresentar uma } \\
\text { proposta de intervenção que } \\
\text { auxilie professores e } \\
\text { gestores da Diretoria de } \\
\text { Ensino de Franca-SP a } \\
\text { trabalharem } \\
\text { conformidade com a } \\
\text { obrigatoriedade da Lei } \mathrm{N}^{\circ} \\
\text { 10.639/2003. }\end{array}$ & $\begin{array}{l}\text { Os referenciais teóricos } \\
\text { utilizados têm como base } \\
\text { estudos culturais, que } \\
\text { avançam na reescrita da } \\
\text { história afro-brasileira de } \\
\text { valorização da cultura } \\
\text { africana; e de } \\
\text { pesquisadores } \\
\text { Ciências Políticas com } \\
\text { ênfase em políticas } \\
\text { públicas educacionais. }\end{array}$ & 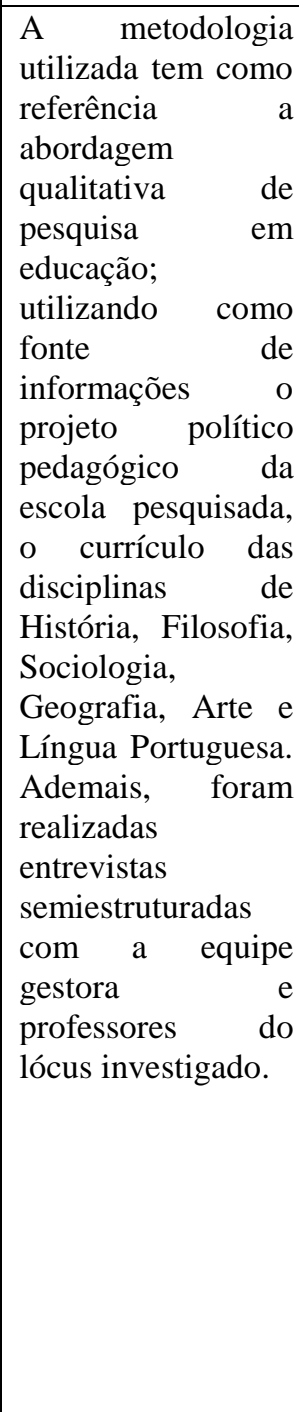 \\
\hline
\end{tabular}




\begin{tabular}{|c|c|c|c|c|c|c|c|c|c|}
\hline TÍTULO & AUTORES & LOCAL & TIPO & ANO & $\begin{array}{l}\text { PALAVRAS } \\
\text { CHAVE }\end{array}$ & RESUMO & OBJETIVO & JUSTIFICATIVA & METODOLOGIA \\
\hline $\begin{array}{l}\text { A lei } \\
10.639 / 2003 \text { e a } \\
\text { literatura luso- } \\
\text { africana e afro- } \\
\text { brasileira na } \\
\text { escola }\end{array}$ & $\begin{array}{l}\text { Souza, Ana } \\
\text { Maria de. A } \\
\text { lei } \\
10.639 / 2003 \text { e } \\
\text { a literatura } \\
\text { luso-africana e } \\
\text { afro-brasileira } \\
\text { na escola, } \\
\text { Porto Alegre, } \\
2013 \text {, } \\
\text { Disponível em } \\
< \\
\text { http://www.ac } \\
\text { ademia.edu/80 } \\
\text { 64436/A_lei_1 } \\
0.639 \text { 2003_e } \\
\text {-a_literatura_1 } \\
\text { uso- } \\
\text { africana_e_afr } \\
\text { o- } \\
\text { brasileira_na_ } \\
\text { escola> } \\
\text { Acesso em: } \\
\text { 25/09/2016. }\end{array}$ & UFRGS & Dissertação & 2013 & $\begin{array}{l}\text { Literatura afro- } \\
\text { brasileira } \\
\text { Leitura } \\
\text { Formação de } \\
\text { leitores } \\
\text { Livro didático } \\
\text { Discriminação } \\
\text { racial } \\
\text { Preconceito }\end{array}$ & 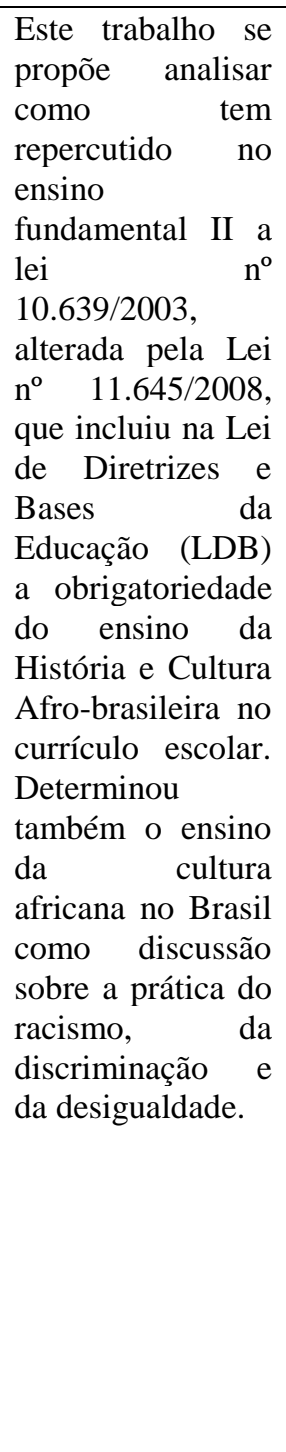 & 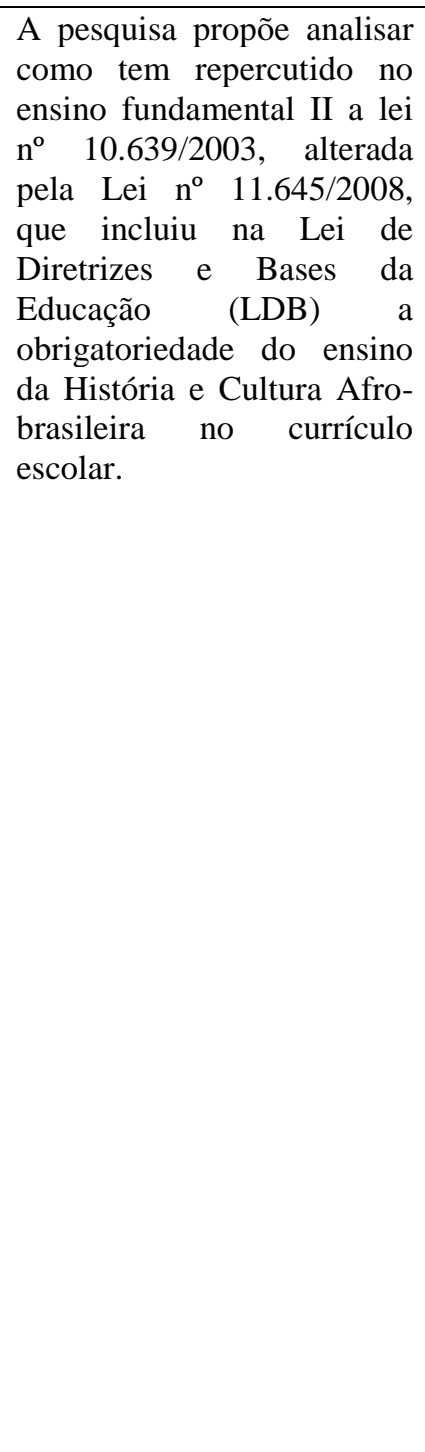 & 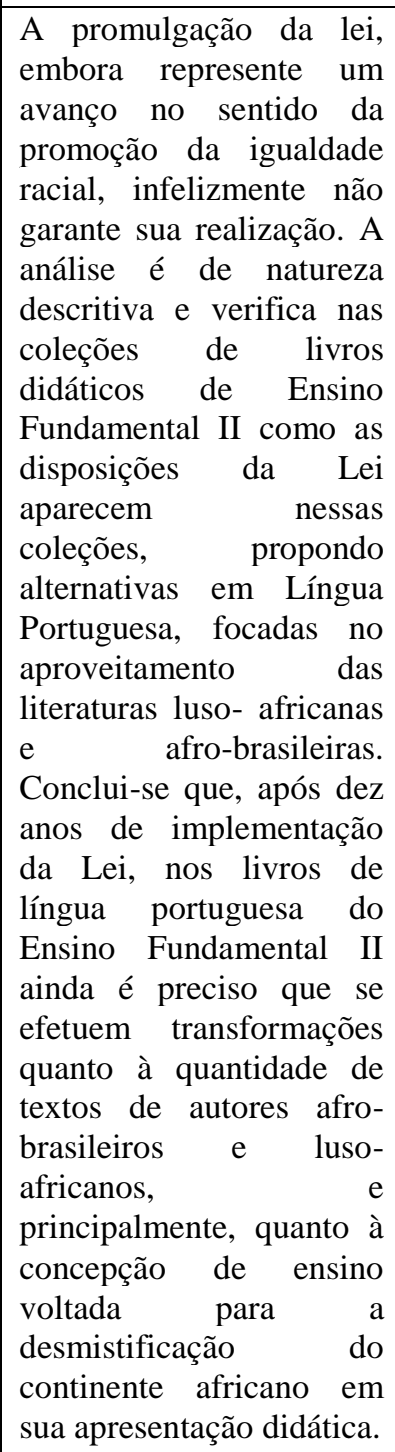 & $\begin{array}{l}\text { Pesquisa } \\
\text { documental, com } \\
\text { análise de natureza } \\
\text { descritiva. }\end{array}$ \\
\hline
\end{tabular}




\begin{tabular}{|c|c|c|c|c|c|c|c|c|c|}
\hline TÍTULO & AUTORES & LOCAL & TIPO & ANO & $\begin{array}{l}\text { PALAVRAS } \\
\text { CHAVE }\end{array}$ & RESUMO & OBJETIVO & JUSTIFICATIVA & METODOLOGIA \\
\hline $\begin{array}{l}\text { Vale do Ribeira: } \\
\text { uma } \\
\text { contribuição das } \\
\text { redes virtuais } \\
\text { quilombolas } \\
\text { para a formação } \\
\text { de professores } \\
\text { de artes visuais } \\
\text { na perspectiva } \\
\text { da lei } \\
10.639 / 2003\end{array}$ & $\begin{array}{l}\text { Perini, Janine } \\
\text { Alessandra. } \\
\text { Vale do } \\
\text { Ribeira: uma } \\
\text { contribuição } \\
\text { das redes } \\
\text { virtuais } \\
\text { quilombolas } \\
\text { para a } \\
\text { formação de } \\
\text { professores de } \\
\text { artes visuais } \\
\text { na perspectiva } \\
\text { da lei } \\
\text { 10.639/2003. } \\
\text { Santa } \\
\text { Catarina, } \\
\text { 2012. } \\
\text { Disponível } \\
\text { em< } \\
\text { http://bdtd.ibic } \\
\text { t.br/vufind/Re } \\
\text { cord/UDSC_e } \\
\text { 487bea7cfa02 } \\
\text { e4b538ddff1f2 } \\
\text { baa187> } \\
\text { Acesso em } \\
\text { 23/09/2016. }\end{array}$ & UDESC & Dissertação & 2012 & $\begin{array}{l}\text { Arte-educação } \\
\text { Lei 10639/2003 } \\
\text { Formação de } \\
\text { professores } \\
\text { Quilombo } \\
\text { Ivaporunduva } \\
\text { Arte Estudo e } \\
\text { ensino }\end{array}$ & 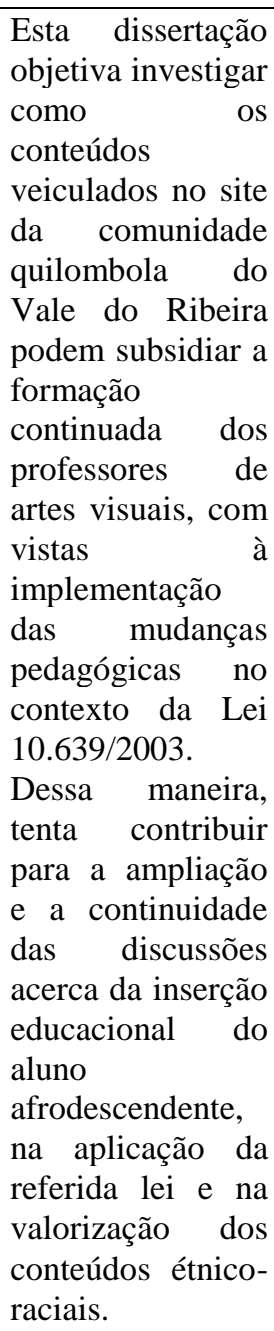 & $\begin{array}{l}\text { Esta dissertação objetiva } \\
\text { investigar como os } \\
\text { conteúdos veiculados no } \\
\text { site da comunidade } \\
\text { quilombola do Vale do } \\
\text { Ribeira podem subsidiar a } \\
\text { formação continuada dos } \\
\text { professores de artes visuais, } \\
\text { com vistas à implementação } \\
\text { das mudanças pedagógicas } \\
\text { no contexto da Lei } \\
\text { 10.639/2003. Dessa } \\
\text { maneira, tenta contribuir } \\
\text { para a ampliação e a } \\
\text { continuidade das discussões } \\
\text { acerca da inserção } \\
\text { educacional do aluno } \\
\text { afrodescendente, na } \\
\text { aplicação da referida lei e } \\
\text { na valorização dos } \\
\text { conteúdos étnico-raciais. }\end{array}$ & $\begin{array}{l}\text { O crescente uso das } \\
\text { tecnologias } \\
\text { informação e da } \\
\text { comunicação, como a } \\
\text { Internet, constitui-se em } \\
\text { uma grande ferramenta } \\
\text { pedagógica, tanto na } \\
\text { formação inicial e/ou } \\
\text { continuada dos } \\
\text { professores de artes } \\
\text { visuais como também em } \\
\text { sala de aula, com os } \\
\text { estudantes. Assim como a } \\
\text { lei acima citada, esta } \\
\text { dissertação contribui para } \\
\text { recuperar aspectos da } \\
\text { cultura afro-brasileira no } \\
\text { Brasil. Nela, enfatizamos } \\
\text { os quilombos brasileiros, } \\
\text { mostrando a contribuição } \\
\text { exploratória, descritiva e } \\
\text { analítica, analisando o } \\
\text { site: } \\
\text { www.quilombosdoribeira } \\
\text {.org.br e a comunidade } \\
\text { Ivaporunduva. }\end{array}$ & $\begin{array}{l}\text { Pesquisa } \\
\text { Bibliográfica. }\end{array}$ \\
\hline
\end{tabular}




\begin{tabular}{|c|c|c|c|c|c|c|c|c|c|}
\hline TÍTULO & AUTORES & LOCAL & TIPO & ANO & $\begin{array}{l}\text { PALAVRAS } \\
\text { CHAVE }\end{array}$ & RESUMO & OBJETIVO & JUSTIFICATIVA & METODOLOGIA \\
\hline $\begin{array}{lr}\text { O ensino } & \text { da } \\
\text { História } & \text { e } \\
\text { cultura } & \text { afro- } \\
\text { brasileira } & \text { em } \\
\text { Rondônia: } & \text { A } \\
\text { aplicação da Lei } \\
\text { 10.639/2003 }\end{array}$ & $\begin{array}{l}\text { Silva, Siméia } \\
\text { de Oliveira } \\
\text { Vaz. O ensino } \\
\text { da História e } \\
\text { cultura afro- } \\
\text { brasileira em } \\
\text { Rondônia: A } \\
\text { aplicação da } \\
\text { Lei } \\
\text { 10.639/2003. } \\
\text { Porto Alegre, } \\
\text { 2015. } \\
\text { Disponível em } \\
< \\
\text { http://bdtd.ibic } \\
\text { t.br/vufind/Re } \\
\text { cord/PUCR_f9 } \\
\text { c9ce49839f65 } \\
\text { 6b41d45eaad9 } \\
\text { 9923a2>. } \\
\text { Acesso em } 28 \\
\text { de setembro } \\
\text { de 2016. }\end{array}$ & PUC/RGS & Dissertação & 2015 & $\begin{array}{l}\text { História } \\
\text { Ensino } \\
\text { Rondônia } \\
\text { Cultura afro } \\
\text { brasileira } \\
\text { Livros } \\
\text { didáticos }\end{array}$ & $\begin{array}{l}\text { A investigação } \\
\text { proposta está } \\
\text { convencionada ao } \\
\text { estudo do ensino } \\
\text { da História e a } \\
\text { aplicabilidade da } \\
\text { Lei 10.639/2003, } \\
\text { sobretudo em } \\
\text { Rondônia. Para } \\
\text { tanto tem como } \\
\text { objeto de pesquisa } \\
\text { o livro didático de } \\
\text { História, } \\
\text { distribuído pelo } \\
\text { PNLD 2012. O } \\
\text { que se procura } \\
\text { descobrir é qual a } \\
\text { visão da História } \\
\text { da África e da } \\
\text { Cultura Afro- } \\
\text { brasileira está } \\
\text { apresentada nos } \\
\text { livros didáticos de } \\
\text { História e se essa } \\
\text { visão permiti a } \\
\text { aplicabilidade da } \\
\text { Lei. }\end{array}$ & $\begin{array}{l}\text { Primeiramente } \\
\text { compreender a trajetória } \\
\text { que tornou possível a } \\
\text { viabilidade da Lei } \\
10.639 / 2003 \text { analisando } \\
\text { documentos como os } \\
\text { Parâmetros Curriculares } \\
\text { Nacionais (PCN's) até as } \\
\text { orientações da Secretaria de } \\
\text { Educação de Rondônia } \\
\text { (SEDUC). Em seguida é } \\
\text { discutido sobre a identidade } \\
\text { afro-rondoniense, } \\
\text { construída num intenso } \\
\text { fluxo migratória que gera } \\
\text { uma crise de identidade. É } \\
\text { feita a análise dos livros de } \\
\text { história do PNLD 2012 para } \\
\text { compreender, se a História } \\
\text { da África e da Cultura Afro- } \\
\text { brasileira neles contido, é } \\
\text { capaz de permitir ao afro- } \\
\text { rondoniense } \\
\text { reconhecimento de sua } \\
\text { identidade. }\end{array}$ & 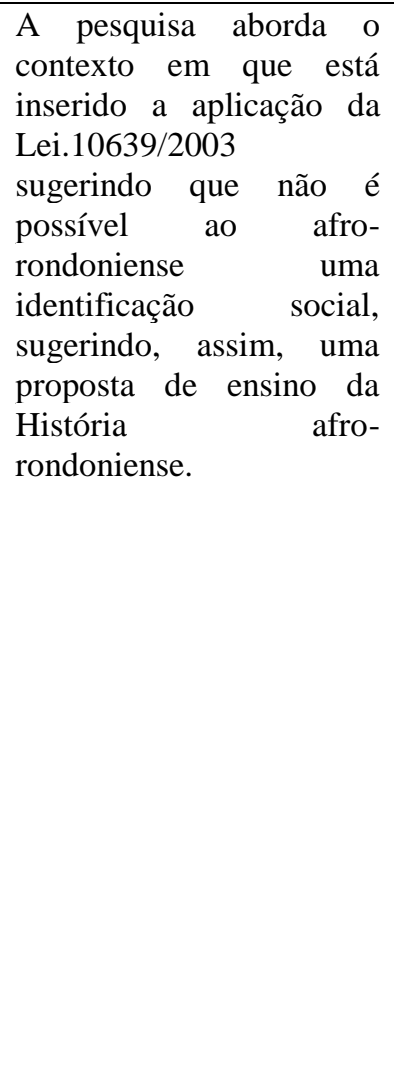 & $\begin{array}{l}\text { Pesquisa } \\
\text { qualitativa, } \\
\text { quantitativa } \\
\text { documental, com } \\
\text { análise de natureza } \\
\text { descritiva. }\end{array}$ \\
\hline
\end{tabular}


